\title{
HYDROGEN COMPATIBILITY HANDBOOK FOR STAINLESS STEELS
}

\section{GEORGE R. CASKEY, JR.}

Approved by

R. L. Folger, Research Manager

Hydrogen and Ceramic Technology Division

Publication Date: June 1983

\section{DISCLAIMER}

This report was prepared as an account of work sponsored by an agency of the United States Government. Neither the United States Government nor any agency thereof, nor any of their employees, makes any warranty, express or implied, or assumes any legal liability or responsibility for the accuracy, completeness, or usefulness of any information, apparatus, product, or process disclosed, or represents that its use would not infringe privately owned rights. Reference herein to any specific commercial product, process, or service by trade name, trademark, manufacturer, or otherwise does not necessarily constitute or imply its endorsement, recommendation, or favoring by the United States Government or any agency thereof. The views and opinions of authors expressed herein do not necessarily state or reflect those of the United States Government or any agency thereof.

\section{E. I. du Pont de Nemours \& Co. Savannah River Laboratory Aiken, SC 29808}

PREPARED FOR THE U. S. DEPARTMENT OF ENERGY UNDER CONTRACT DE-ACO9.76SR00001 


\section{DISCLAIMER}

This report was prepared as an account of work sponsored by an agency of the United States Government. Neither the United States Government nor any agency Thereof, nor any of their employees, makes any warranty, express or implied, or assumes any legal liability or responsibility for the accuracy, completeness, or usefulness of any information, apparatus, product, or process disclosed, or represents that its use would not infringe privately owned rights. Reference herein to any specific commercial product, process, or service by trade name, trademark, manufacturer, or otherwise does not necessarily constitute or imply its endorsement, recommendation, or favoring by the United States Government or any agency thereof. The views and opinions of authors expressed herein do not necessarily state or reflect those of the United States Government or any agency thereof. 


\section{DISCLAIMER}

Portions of this document may be illegible in electronic image products. Images are produced from the best available original document. 
$\bullet$

i

•

$-2-$ 1 


\section{ABSTRACT}

This handbook compiles data on the effects of hydrogen on the mechanical properties of stainless steels and discusses this data within the context of current understanding of hydrogen compatibility of metals. All of the tabulated data derives from continuing studies of hydrogen effects on materials that have been conducted at the Savannah River Laboratory over the past fifteen years. Supplementary data from other sources are included in the discussion. Austenitic, ferritic, martensitic, and precipitation hardenable stainless steels have been studied. Damage caused by helium generated from decay of tritium is a distinctive effect that occurs in addition to the hydrogen damage from tritium which is the same as for the other hydrogen isotopes protium and deuterium. The handbook defines the scope of our current knowledge of hydrogen effects in stainless steels and serves as a guide to selection of stainless steels for service in hydrogen. 


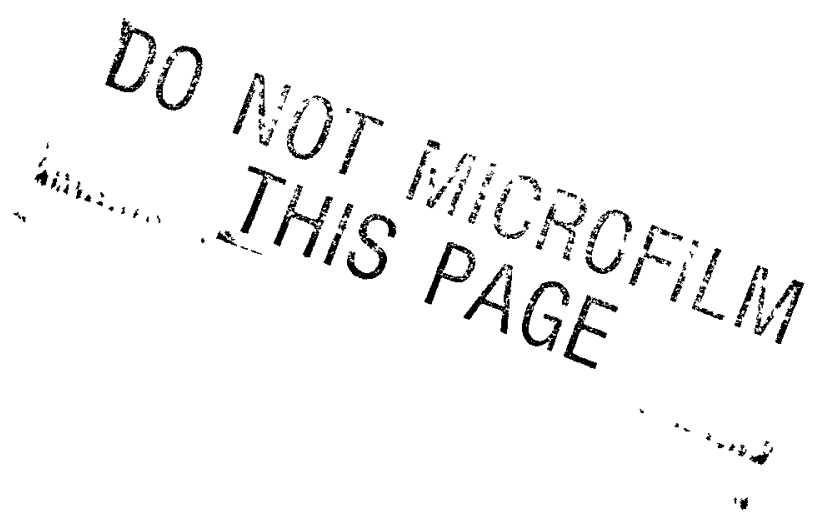




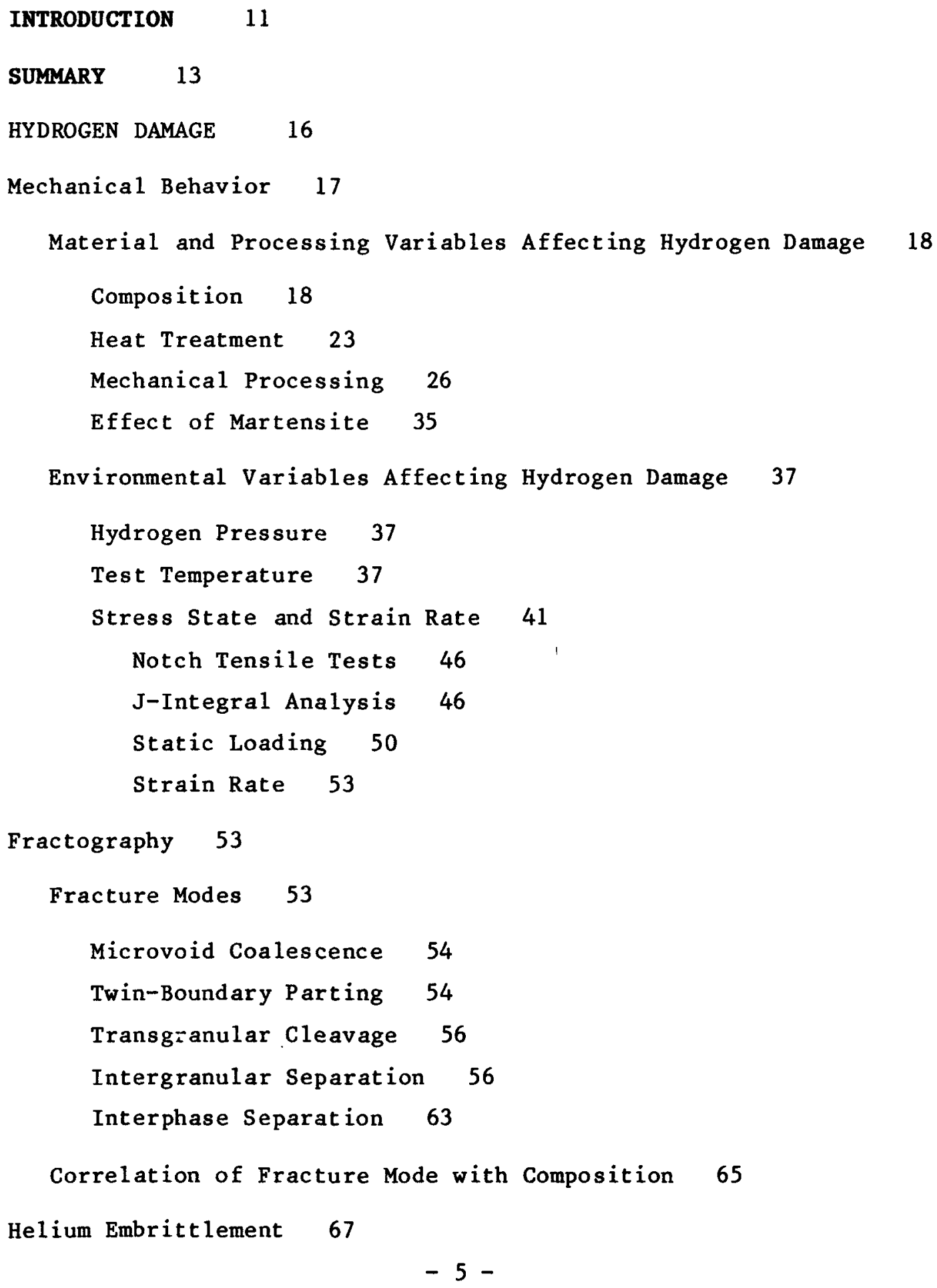


CONTENTS, Contd

CONCLUSIONS $\quad 75$

ACKNOWLEDGEMENTS $\quad 77$

ALLOY DATA SHEETS 78

Alloy Index 78

Iron-Chromium-Nickel Alloys 78

Iron-Chromium-Nicke1-Manganese Alloys 78

Precipitation Hardenable Alloys 78

High Purity Alloys 78

REFERENCES 124

APPENDIX A. DEFINITIONS 131

APPENDIX B. CONVERSION TABLES 133

Temperature Conversions 133

English/Metric (SI) Stress Conversion Factors 134

English/Metric (SI) Fracture Toughness Conversion Factors 136

English/Metric (SI) Impact Energy Conversion Factors 137

APPENDIX C. MECHANICAL TEST SPECIMENS 138

Smooth Bar Tensile Specimens 138

Notched Bar Tensile Specimens 140

Tensile Tube Specimen 142

Single Edge Notched Specimen 143

C-Shaped Fracture Mechanics Specimen 145

Impact Specimen 147

APPENDIX D. HEAT ANALYSES 148 


\section{LIST OF TABLES}

1 Ranking of Hydrogen Damage 14

2 Hydrogen Damage Susceptibility 14

3 Mechanical Properties of HERF and Annealed Alloys in High-Pressure Gas 31

4 Effect of Martensite on Subsequent Environmental Hydrogen Damage in Type 304L Stainless Steel 36

5 Temperatures for Strain-Induced Martensite Formation 43

6 Effect of Hydrogen Charging on Tensile Properties of Type 304L Stainless Steel 49

7 Ranking of Hydrogen Compatibility (HERF Stainless Stee1s) $\quad 49$

8 Stress Necessary for Slow Crack Growth in Type 304L Stainless Steel 52

9 Occurrence of Microcracks in Hydrogen-Saturated Austenitic Stainless Steels 58

10 Mechanical Properties of HERF Type 304L Stainless Steel 70

11 Mechanical Properties of HERF Nitronic 40 Stainless Stee1 70

12 Tritium and Helium Effects on Fracture Toughness of Stainless Steels 73 


\section{LIST OF FIGURES}

1 Environmental Hydrogen Damage in $\mathrm{Fe}-\mathrm{Cr}-\mathrm{Ni}$ Alloys at Room Temperature and $69 \mathrm{MPa}$ Hydrogen 19

2 Stacking Fault Energies in $\mathrm{Fe}-\mathrm{Cr}-\mathrm{Ni}$ Alloys at Room Temperature 21

3 Environmental Hydrogen Damage in $\mathrm{Fe}-\mathrm{Cr}-\mathrm{Ni}-\mathrm{Mn}$ Alloys at Room Temperature and $69 \mathrm{MPa}$ Hydrogen 22

4 Hal1-Petch Plot for Tensile-Test Specimens of Type 304L Stainless Steel at a Plastic Strain $\varepsilon=0.0524$

5 Hall-Petch Plot of Yield Strength for Type 304L Stainless Steel Tested in High-Pressure Helium or Hydrogen Environments 25

6 Effect of Prestrain on Tensile Strength of Type 304L Stainless Steel Tubes in Air or Hydrogen 27

7 Effect of Prestrain on Elongation of Type 304L Stainless Stee1 in Air or Hydrogen 28

8 Effect of Prior Cold Work on Hydrogen Damage Susceptibility of Stainless Steels 30

9 Effect of Processing on Hydrogen Damage in Nitronic 40 Elongation 32

10 Effect of Processing on Hydrogen Damage in Nitronic ${ }^{*}$ 40 Strength 33

11 Orientation of V-Notch with Respect to Forging Flow Lines in Tensile-Test Specimens Machined from Bars of HERF Stainless Steels 34

12 Effect of Hydrogen Pressure on Ductility of Type $304 \mathrm{~L}$ Stainless Steel Tested to Fracture in Hydrogen at Room Temperature $\quad 38$

13 Dutility Minima in $\mathrm{Fe}-\mathrm{Cr}-\mathrm{Ni}$ Alloys Charged with Deuterium at $69 \mathrm{MPa}$ and $620 \mathrm{~K}$ for Three Weeks 39

14 Ductility Minima in Fe-Cr-Mn-Mi Alloys Charged with Deuterium at $69 \mathrm{MPa}$ and $620 \mathrm{~K}$ for Three Weeks 40 


\section{LIST OF FIGURES, CONTD}

15. Isoductility Diagram for Hydrogen-Charged Fe-Cr-Ni Alloys

16 Effect of Hydrogen on Strain-Induced Martensite Formation in Type 304L Stainless Stee1 44

17 Effect of Hydrogen on Strain-Induced Martensite Formation in Tenelon ${ }^{\circledR}$ and Nitronic $40 \quad 45$

18 Relative Effect of Hydrogen on Properties of Sensitized Type 304L Stainless Steel 47

19 Environmental Hydrogen Damage in Nitronic 40 Stainless Stee1 at Room Temperature 48

20 Hydrogen Effects on Crack Growth in Stainless Steels 51

21 Dimpled Fracture of Type 304L Stainless Steel 55

22 Twin-Boundary Parting in Type 304L Stainless Steel. High Energy Rate Forged. Tested at $200 \mathrm{~K} \quad 55$

23 Microcracks Along Boundaries of Annealing Twins 57

24 Variation of Facet Appearance with Test Temperature in Type $304 \mathrm{~L}$ Stainless Steel 59

25 Multiple Crack Nucleation Along Boundaries 60

26 Transgranular Cleavage in 17-4 PH PrecipitationHardenable Stainless Steel 61

27 Intergranular Separation in Nickel and Inconel 71861

28 HERF Nitronic 40 , Orientation 1. Intergranular Fracture in Hydrogen 62

29 Fracture Along Interphase Interfaces in Austenitic Steels 64

30 Composition Regimes for Fracture Modes Observed in HAF of Iron-Chromium-Nicke1 Alloys 66

31 Helium bubbles in Type 304L Stainless Steel Tritium Charged, Aged, and Annealed at $1273 \mathrm{~K} \quad 68$

32 Microstructures in HERF Nitronic ${ }^{\circledR} 40 \quad 71$ 


\section{DO NOT MOROFLM
THIS PAGE}




\section{HANDBOOK OF DATA ON HYDROGEN COMPATIBILITY OF STAINLESS STEELS}

\section{INTRODUCTION}

This handbook is based on studies of hydrogen effects in metals that have been conducted at the Savannah River Laboratory (SRL) over the past 15 years. The major part of this continuing study deals with austenitic, martensitic, and precipitation hardenable stainless steels and is the subject of this handbook. The handbook also includes data on high nickel alloys, iron-nickel, iron-chromium alloys and pure nickel. These alloys are similar to the stainless steels and their inclusion provides a more complete coverage of the iron-chromium-nickel ternary alloy system.

Stainless steels have been utilized in structures and equipment for hydrogen storage, rocket engines, and petrochemical processing. Temperatures range from cryogenic to several hundred Kelvin and effective hydrogen pressures often exceed $20 \mathrm{MPa}$. In addition, hydrogen may be encountered as a corrosion product and may contribute to degradation of equipment in such circumstances. The data presented in this handbook covers the effects of hydrogen on stainless steels at temperatures of 78 to $400 \mathrm{~K}$ and at pressures up to $69 \mathrm{MPa}$. Therefore, the results are applicable to only a portion of all possible industrial applications of stainless steel in hydrogen environments.

There are two principal sections to this handbook: Alloy Data Sheets which tabulate mechanical properties for each alloy and Hydrogen Damage which discusses the hydrogen compatibility of stainless steels. The mechanical property data for each alloy are tabulated separately on one or more data sheets and indexed by alloy number or trade name. The nominal compositions and mechanical properties of the alloys are included in tables immediately following the index. The discussion of hydrogen damage draws upon published information from the technical literature to supplement the SRL data.

The scope of the data accumulated on hydrogen damage varies widely among the alloys that have been studied. In all cases, tensile property measurements have been emphasized and fracture modes examined. Fracture-mechanics-type specimens have been studied in several alloys. Studies of Type 304L stainless steel have been the most extensive. They include bar, cross-rolled plate, and High Energy Rate Forged (HERF) stock. The effects of grain size, heat treating temperatures, and quench rates on susceptibility to hydrogen damage have also been examined.

$$
-11-
$$


Mechanical behavior, fracture modes, helium embrittlement which may arise by beta decay of tritium, and hydrogen damage mechanisms are discussed. Although a uniform and consistent data base does not exist for each of the alloys, general trends in susceptibility to hydrogen damage have been identified. Changes in mechanical behavior and fracture mode attributable to hydrogen have been correlated with alloy composition, heat treatment, stress state, and test temperature. The data base does provide sufficient information for guidance in alloy selection and development of new alloys tailored to specific service requirements.

During the past decade, several international conferences and symposia have concentrated on hydrogen effects on metals, References 1 through 11. Proceedings of these meetings provide interpretation and evaluation of hydrogen damage studies as well as mechanical and physical property data on a variety of alloys other than stainless steel. Hydrogen Damage, edited by C. D. Beachem, Reference 12 , is a selection of papers from the technical literature that provides an overview and insight into hydrogen damage, as does the review paper by Hirth and Johnson, Reference 13.

Many of the publications and presentations at technical meetings by researchers at the Savannah River Laboratory deal with hydrogen effects in stainless steel. Only a few have been referenced directly in the text, the remainder are listed in references 46 through 71. These papers supplement this Handbook and provide more detailed discussion of specific topics. 
The susceptibility of stainless steels to hydrogen damage has been evaluated primarily under rising uniaxial load rather than under static or fatigue loading conditions. Smooth, notched, and fatigue cracked specimens have been tested and hydrogen damage assessed by measuring either fracture strain or the J-integral. As shown in Table 1 , stainless steels may be ranked qualitatively according to the severity of damage measured on specimens precharged with hydrogen at hydrogen pressures up to $69 \mathrm{MPa}$ prior to testing.

Ranking of alloys will not in general be the same for static or fatigue loading as for rising load conditions as seen in Table 2 . Slow-crack growth under static loading has been reported for A-286, JBK-75, and Nitronic $\$-40$ at stresses substantially below the ultimate tensile strength, but not for Type $304 \mathrm{~L}$ stainless steel.

The J-integral analysis of tensile data has been applied to tests of smooth and C-shaped specimens. Both $J$ at maximum load and tearing resistance (change of $J$ with crack length) are sensitive to alloy composition, crack orientation relative to deformation texture, and test environment. The susceptibility to hydrogen damage of several alloys was evaluated by the J-integral. Results were similar to evaluation based on reduction- in-area in smooth bar tensile test but more sensitive to orientation. The J-integral is more versatile than a ductility parameter as it is applicable to specimen designs that do not have an easily measured ductility parameter.

Helium embrittlement at ambient temperature has been found in five types of austenitic stainless steel: HERF Type 340L, HERF Type 316, HERF Nitronic ${ }^{(10}$ 40 (21-6-9 stee1), HERF A-286, and annealed JBK-75 (a modified A-286). Helium was generated within the specimens by radioactive decay of tritium which had been diffused into the alloys at $420 \mathrm{~K}$ from high pressure $(65 \mathrm{MPa})$ gas. Fracture toughness of the alloys decreased with increasing accumulation of helium. Damage was least in HERF Type 316 and greatest in HERF Nitronic 40 and JBK-75. Sustained load tests indicate that the stress intensity for crack initiation and propagation also decreases with increasing helium concentration. Helium damage appears to be additive to the damage caused by the hydrogen isotopes and on a per atom basis appears to be more severe than hydrogen damage.

Additional observations on hydrogen damage may be derived from the data: 
TABLE 1

Ranking of Hydrogen Damage*

\begin{tabular}{|c|c|c|}
\hline Minimal & Moderate & Severe \\
\hline 316 & $304 \mathrm{~N}$ & CG-27 \\
\hline \multirow[t]{2}{*}{310} & $304 \mathrm{~L}$ & $17-4$ \\
\hline & Incone ${ }^{\circledast 718}$ & 216 \\
\hline $3095 * *$ & Nitronic ${ }^{\circledR}-40$ & Tene1on ${ }^{\oplus}$ \\
\hline Nitronic ${ }^{\circledR}-50$ & $A-286$ & $18-18 \mathrm{Plus}^{(8)}$ \\
\hline Incoloy $800 \mathrm{H}$ & $\mathrm{JBK}-75$ & $\mathrm{Ni}$ \\
\hline $\mathrm{X} 18-3 \mathrm{Mn} * *$ & $\operatorname{AM} 363 * *$ & AM350 \\
\hline $\mathrm{Ni}-\mathrm{SPAN}-\mathrm{C} * *$ & 18-2 Mn** & \\
\hline
\end{tabular}

* Based on tensile ductility. Nominal compositions of these alloys are listed in Table AI.

** Ranking of these alloys is tentative.

\section{TABLE 2}

Hydrogen Damage Susceptibility

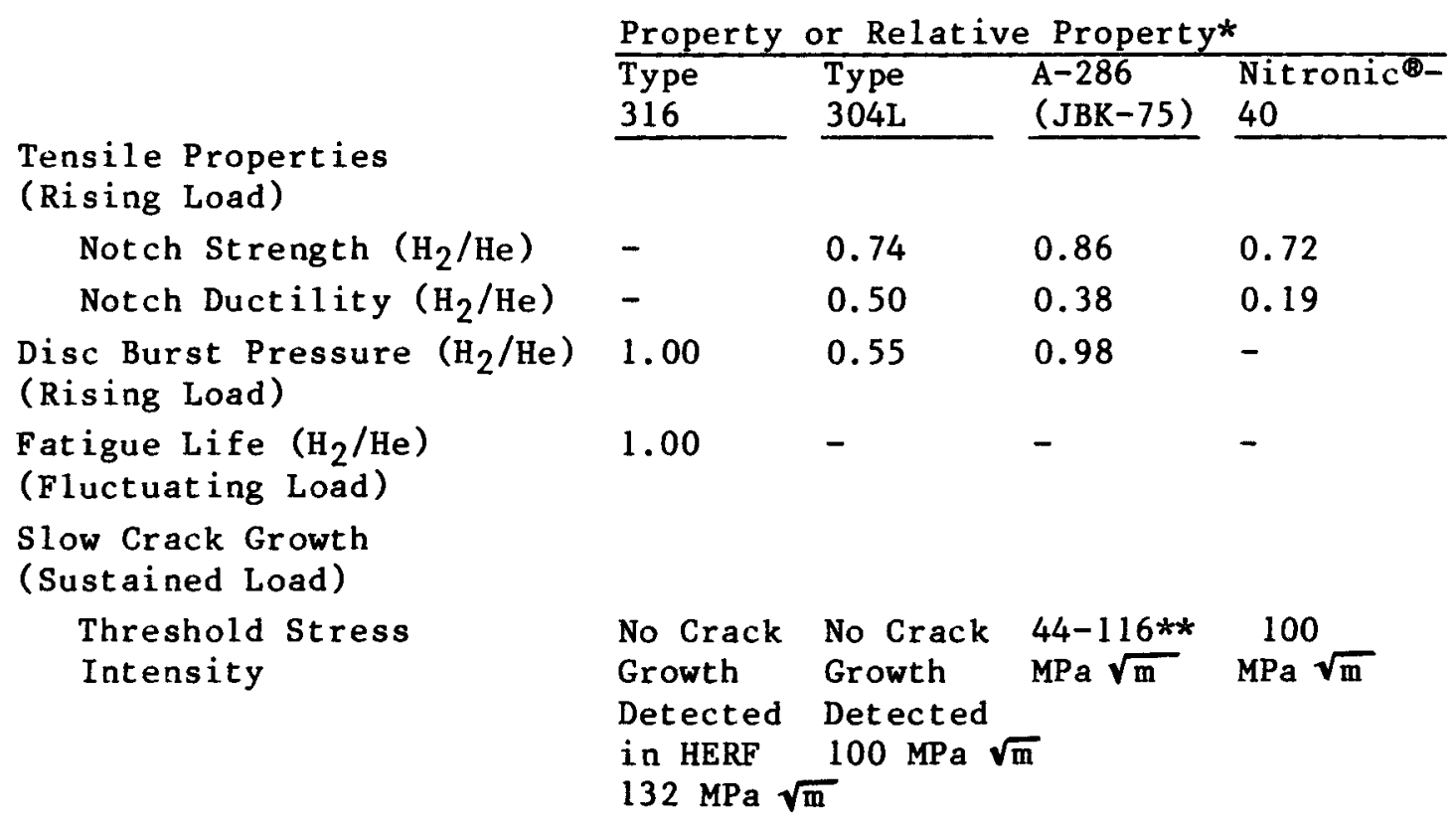

* Values $<1.00$ show effect of hydrogen by comparison with data obtained in helium atmospheres.

** Variable depending upon heat treatment and precipitate morphology. 
- In $\mathrm{Fe}-\mathrm{Cr}-\mathrm{Ni}$ base alloys environmental hydrogen compatibility at room temperature is maximized for alloys containing 15 to $30 \%$ nickel. The role of other alloy elements has not been established, but small additions of molybdenum ( 2 to $3 \%$ ) appear beneficial.

- In Fe-Cr-Ni-Mn alloys, hydrogen compatibility improves as nickel content increases. Manganese is not a substitute for nickel for hydrogen compatibility in spite of the fact that manganese like nickel stabilizes austenite.

- There is a ductility minimum in the temperature range $200-300 \mathrm{~K}$ where hydrogen damage is most pronounced. This ductility minimum is observed even in alloys which show minimal hydrogen damage and no fracture mode change such as Type 310 and 316 stainless steels.

- Nitrogen contents greater than about 0.3 wt \% appear to aggravate hydrogen damage in $\mathrm{Fe}-\mathrm{Cr}-\mathrm{Ni}-\mathrm{Mn}$ alloys.

- Impurities normally present in commercial austenitic stainless steels (silicon, manganese, sulfur, and phosphorus) do not appear to influence susceptibility to hydrogen damage relative to pure alloys. Segregation of these elements is potentially harmful, however.

- Increased strength with no loss or a small improvement in hydrogen compatibility is achieved by high energy rate forging (HERF) of austenitic stainless steels.

- The presence of hydrogen often evokes brittle fracture modes under loading and temperature conditions where ductile failure by microvoid coalescence ordinarily occurs. However, fractography by itself is not adequate to diagnose hydrogen assisted fracture in stainless steels because each brittle fracture mode has been observed under other conditions. 
Hydrogen damage occurs to all structural alloys, including stainless stee1s.12-13 The widespread occurrence of hydrogen damage is directly connected to the easy absorption of hydrogen into metals and the high mobility of hydrogen in metals. Hydrogen interacts with lattice defects, impurities, and internal boundaries leading to a nonuniform distribution even for the equilibrium state. Consequently, hydrogen is segregated along boundaries and in regions of high stress or strain, thus localizing hydrogen damage in regions which are often favorable sites for microcrack initiation. Hydrogen segregation is more pronounced in ferritic than in austenitic steels because of the larger elastic strain of the hydrogen at om in the lattice of the ferritic steels.11

There is no one physical process that is responsible for hydrogen embritt lement of metals.12-13 At least three distinguishable forms of hydrogen degradation are recognized: hydride embrittlement, hydrogen attack, and hydrogen-assisted fracture (HAF). The first two processes are understood reasonably well, whereas the last process has not yet been rationalized satisfactorily. Hydride embrittlement occurs in metals such as niobium, titanium, and zirconium, which form distinctive hydride phases which are thermodynamically stable under ordinary ambient conditions. These hydrides have a larger specific volume than the base metal from which they form and appear to be inherently brittle. The hydrides form structures with low crystal symmetry. Brittleness arises because of the limited number of slip systems available in these crystal structures.

Hydrogen attack applies to formation of a gaseous product by reaction of dissolved hydrogen with constituents such as oxygen and carbon or with oxides and carbides present in the alloy. At elevated temperature, steam or methane forms and generates microcracks containing the reaction gas under pressure. This form of hydrogen damage has been found in copper (steam embrittlement) and carbon steels (methane formation). The addition of nitrogen to stainless steels strengthens the austenite and creates a situation where reaction between hydrogen and nitrogen could produce ammonia and cause damage in the same way as oxygen or carbon. This form of hydrogen attack has not been reported, however.

Hydrogen-assisted fracture occurs in many metals, including the stainless steels. This form of hydrogen damage is characterized by the occurrence of a ductility minimum, an inverse strain 
rate sensitivity, and crack propagation under static load at a stress intensity less than the fracture toughness of the alloy. The nature and degree of the damage vary widely, however, depending on alloy composition, temperature, loading mode (static, cyclic, increasing), stress state, and the environment. Only a few valid generalizations can be made for hydrogen-assisted fracture of stainless steels because the above influencing factors have not been systematically investigated.

There is experimental evidence that internal boundaries may be needed for significant hydrogen damage to occur. Investigations of pure iron have demonstrated that the strength and fracture mode of single crystals are unaffected by hydrogen either precharged to the metal cathodically or charged during straining. 14 Likewise, fracture of single crystals of pure nickel is unaffected by hydrogen. 15 It is to be noted, however, that serrated yielding was observed during tensile straining of nickel at temperatures of 150 to $270 \mathrm{~K}$, providing evidence of hydrogen binding to dislocations. In contrast, polycrystalline specimens of iron and nickel are known to be severely embrittled by hydrogen. No hydrogen damage studies have been attempted with single crystals of any stainless steel. However, crystals free of internal boundaries may not be attainable because of the ease of formation of annealing twins in these steels. As noted later in this report, hydrogen-assisted fracture of stainless steel frequently propagates along twin or grain boundaries. Furthermore, ductile fracture processes can be altered by hydrogen accumulation at inclusion-matrix interfaces by diffusion or a dislocation transport mechanism. 16 Hydrogen may alter either nucleation or growth of microvoids, depending upon the nature of the inclusion-matrix or precipitate-matrix interfaces. 17 Consequently, dimple size on fracture surfaces may be either decreased or increased by the presence of hydrogen.

\section{MECHANICAL BEHAVIOR}

Hydrogen has a pronounced effect on crack initiation and growth but only a small effect on deformation behavior. Therefore, mechanical properties that are sensitive to crack behavior are suited to hydrogen damage studies. The most severe tests involve high stress or large plastic strain. Fatigue and creep rupture are two such tests. However, tensile tests of smooth and notched round specimens have been the principal methods for evaluating the susceptibility of stainless steels to hydrogen damage because of low cost and simple test procedure. Change in reduction-in-area has been the most commonly used index of hydrogen damage. Generally, if there is a loss in reduction-in-area, other mechanical properties are affected also; however, the converse is not true. Consequently, the tensile test is of limited applicability as a screening test for susceptibility to hydrogen damage. Recently, J-integral 
techniques have been applied to analysis of tensile data of fatigue precracked specimens, either single-edge notched (SENT) or C-shaped. Impact specimens and internally pressurized tensile tubes have been tested in limited numbers.

Specimens have been tested following exposure to high-pressure (about $1 \mathrm{MPa}$ to $69 \mathrm{MPa}$ ) hydrogen (internal hydrogen damage) or in the presence of high-pressure (69 MPa) hydrogen gas (external hydrogen damage). Tests with an external hydrogen source were conducted at room temperature only. In contrast, mechanical testing of hydrogen-charged specimens has been done at 4.2 and $78 \mathrm{~K}$ and at temperatures between 200 and $400 \mathrm{~K}$.

Mechanical property data for the stainless steels that have been studied at SRL are collected in the Alloy Data Sheets. The tables are organized by alloy and by type of test for each alloy.

\section{Material and Processing Variables Affecting Hydrogen Damage}

There are distinct differences in the degree of hydrogen damage among the stainless steels. Alloy composition provides a simple scheme for classifying steels according to severity of hydrogen damage. Such a criterion does not, however, provide any insight into the reasons for the observed differences in response to hydrogen. Properties such as phase stability, stacking fault energy, or dislocation slip mode are related to composition and are directly related to the processes of crack initiation and propagation. Microstructure as established by heat treatment and mechanical processing modifies hydrogen damage for any given composition of steel. Thermal and mechanical treatments influence severity of hydrogen damage in a steel through changes in grain size, alloy and impurity segregation, precipitate size distribution and coherence, and dislocation substructures. Severity of hydrogen damage may be altered in practice by alloy composition, heat treatment, and mechanical processing. Examples of these effects are cited below.

\section{Composition}

Stainless steels considered in this report fall into two broad composition classes: iron-chromium-nickel and iron-chromiumnickel-manganese. The latter class of alloys all contain nitrogen which is added to strengthen the austenite.

Environmental embrittlement of iron-chromium-nickel alloys correlates with nickel content, as seen in Figure 1. These results were obtained from tensile tests in a $69 \mathrm{MPa}$ hydrogen environment at room temperature. This correlation appears valid for both high purity and commercial grades of steel. Consequently, elements 


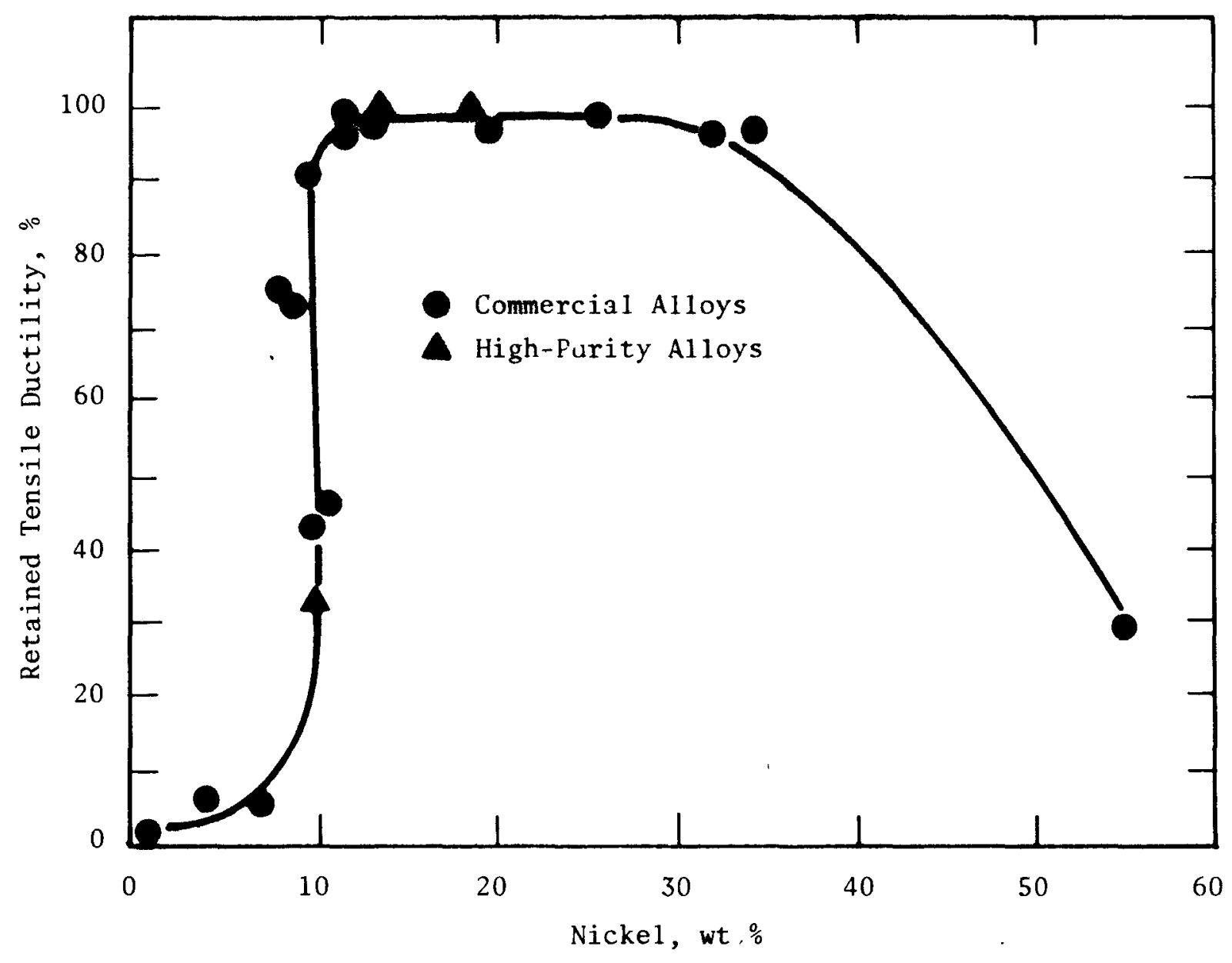

FIGURE 1. Environmental Hydrogen Damage in $\mathrm{Fe}-\mathrm{Cr}-\mathrm{Ni}$ Alloys at Room Temperature and $69 \mathrm{MPa}$ Hydrogen 
present as minor alloy constituents such as manganese, silicon, phosphorus, and sulfur are not primary sources of hydrogen damage. As will be shown later, however, segregation of some minor alloying elements can alter the extent of hydrogen damage.

The composition range from 8 to $14 \%$ nickel, where the marked improvement in resistance to hydrogen damage occurs, corresponds to increased austenite stability and decreased formation of martensite during plastic deformation. According to the equilibrium diagram calculated by Breedis and Kaufman for pure iron-chromium-nickel alloys, austenite is the stable phase above $19 \%$ nickel for a $20 \%$ chromium alloy at $300 \mathrm{~K} .18$ The high-purity alloys tested at SRL indicate that as 1 ittle as $14 \%$ nickel will stabilize austenite with respect to transformation to $\alpha^{\prime}$-martensite at room temperature. Furthermore, austenite stability with respect to transformation to the epsilon phase increases as the nickel content is increased from 10 to $20 \%$. Figure 2 shows the composition dependence of stacking fault energy, which is a measure of austenite stability with respect to the epsilon phase.19 Both $\alpha^{\prime}$-martensite and epsilon phase are detrimental, as resistance to hydrogen damage is rapidly improved over the range of nickel concentrations ( 10 to $20 \%$ ) corresponding to increased austenite stability. However, as discussed later, the relation between martensite and hydrogen damage is neither simple nor clearly demonstrated.

Hydrogen damage in the $\mathrm{Fe}-\mathrm{Cr}-\mathrm{Ni}-\mathrm{Mn}$ alloys as measured by ductility in high-pressure hydrogen does not correlate uniquely with nickel or with equivalent nickel $[\mathrm{Ni}+30(\mathrm{C}+\mathrm{N})+0.5 \mathrm{Mn}]$. For several compositions, Figure 3, a range of results may be obtained. This range of behavior is probably caused by variations in nitrogen content as documented for Nitronic 40 (21-6-9 stainless stee1). 20 The higher nitrogen contents not only strengthen the alloy but also reduce the stacking fault energy, thereby promoting coplanar dislocation arrays and formation of epsilon phase. 21

The influence of other major elements such as chromium, manganese, and molybdenum on susceptibility to hydrogen damage is not well documented. Most commercial stainless steels contain 15 to $25 \%$ chromium with $18-20 \%$ being the most common concentration. Variations in hydrogen damage among the stainless steels cannot be linked directly to chromium because the other alloying elements change simultaneously. Chromium stabilizes ferrite, which is more susceptible to hydrogen damage than austenite, therefore, a high chromium content is expected to be detrimental.

Molybdenum appears to alleviate hydrogen damage when present in small amounts, $2-3 \%$, as indicated by comparison of Type 316 with Type 304 stainless steel. However, Type 316 stainless stee 1 also has a nickel content about $2 \%$ higher than Type 304 stainless steel. The higher nickel cannot account completely for the reduced 


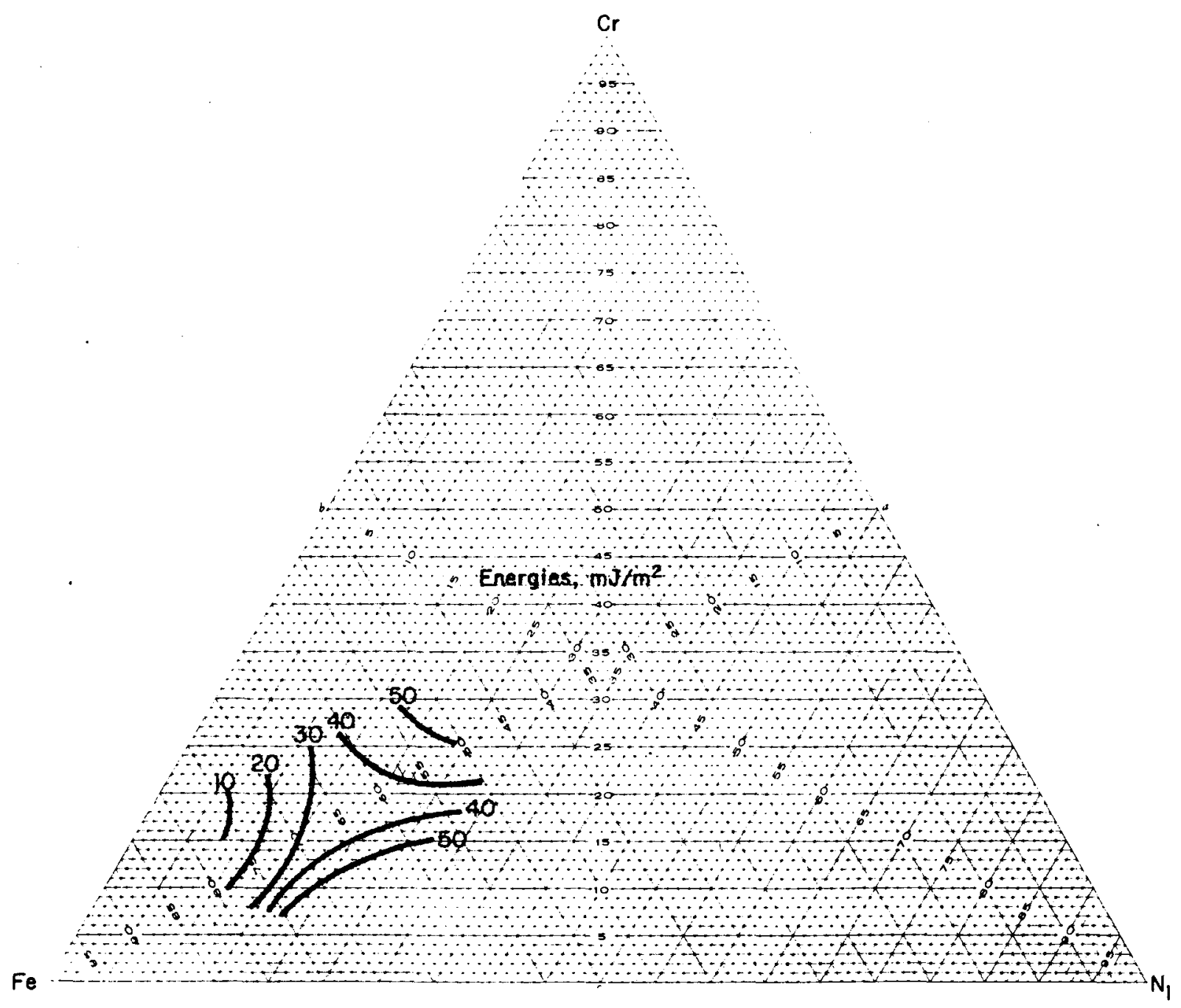

FIGURE 2. Stacking Fault Energies in Fe-Cr-Ni Alloys at Room Temperature (Ref. 19) 


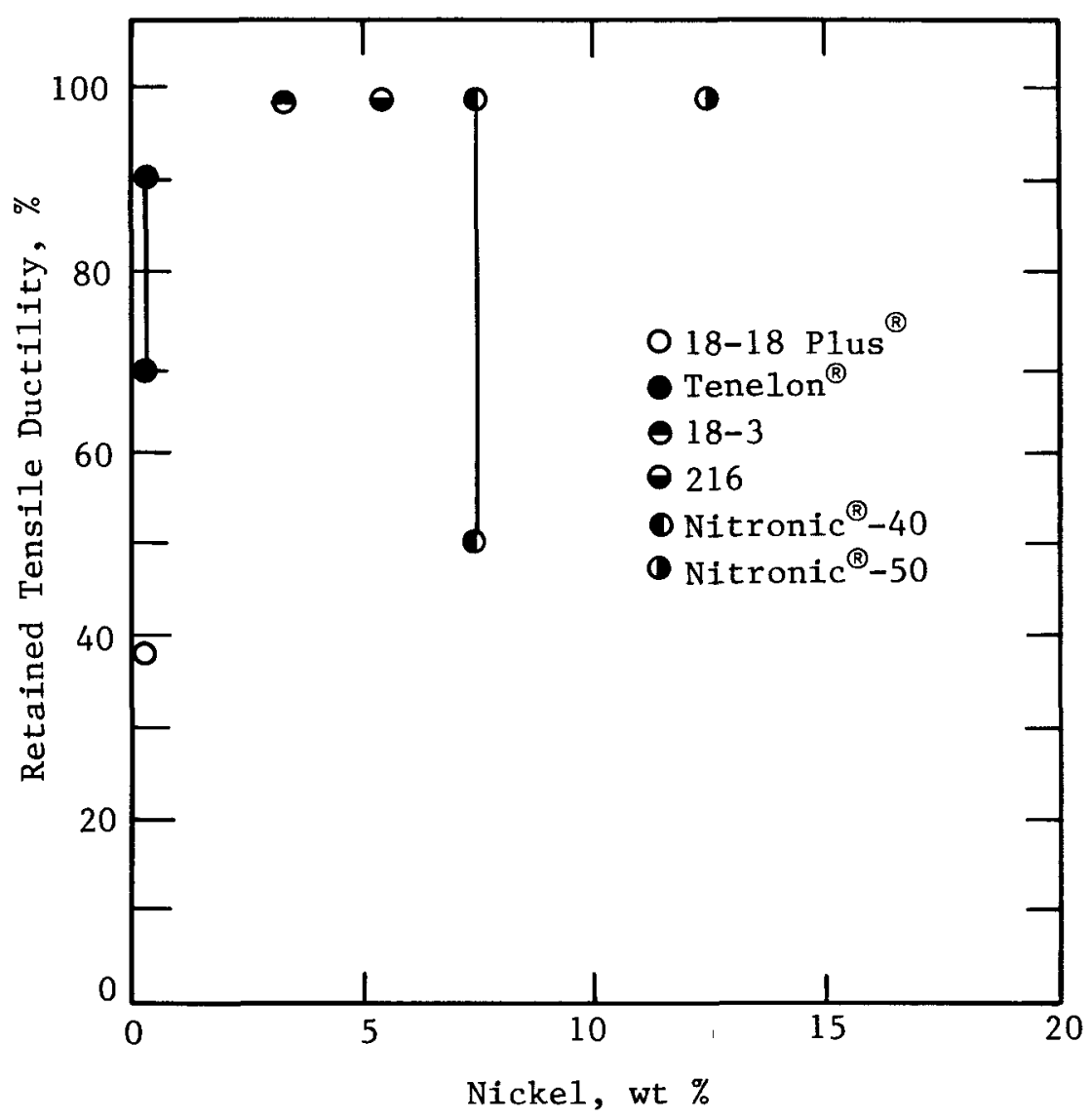

FIGURE 3. Environmental Hydrogen Damage in Fe-Cr-Ni-Mn Alloys at Room Temperature and 69 MPa Hydrogen 
hydrogen damage because an alloy with $14 \%$ nickel with no molybdenum shows greater hydrogen damage than Type 316 stainless steel. Large concentrations of molybdenum $(>5 \%)$ are expected to aggravate hydrogen damage because molybdenum stabilizes ferrite.

Manganese stabilizes austenite and should improve hydrogen performance of stainless steels. However, alloys with high manganese contents and little or no nickel such as Tenelon (U. S. Steel Corp.) and 18-18 P1us (Carpenter Technology) behave very poorly in hydrogen, Figure 3, indicating that austenite stability in itself is not sufficient to minimize hydrogen damage.

\section{Heat Treatment}

Heat treating has been shown to affect susceptibility to hydrogen damage in several ways: change of grain size, segregation or redistribution of impurities and alloying elements, and precipitation of new phases. The general patterns of variation in hydrogen damage with composition can be modified, therefore, by heat treatment.

The only study of the effect of grain size on hydrogen damage has been made with Type 304L stainless steel. As seen in Figure 4, flow stress was increased by finer grain size and the effect was greater in specimens that were saturated with hydrogen. Grain size effect on the yield strength of specimens tested in high-pressure hydrogen, was the same as for tests in helium, Figure 5. Presumably, comparable results would be obtained with the other alloys.

The grain size dependence of the flow stress $\left(\sigma_{f}\right)$ follows the Ha11-Petch relation, $\sigma_{f}=\sigma_{o}+k_{f} d^{-1 / 2}$, where $\sigma_{o}$ and $k_{f}$ are functions of strain and $d$ is grain size. Analysis of the data demonstrates that hydrogen strengthening is associated with the back stress of dislocation pileups against internal boundaries and the increased resistance to dislocation' intersection where hydrogen is present.22 Hydrogen causes only a small increase in lattice friction stress in keeping with the relatively small lattice distortion caused by an interstitial hydrogen atom in the face centered cubic lattice. 11

Sensitization of austenitic stainless steels occurs during heating to temperatures in the range $720 \mathrm{~K}$ to $1150 \mathrm{~K}$, or upon cooling slowly through this range. Chromium-rich carbides of the general form $M_{23} C_{6}$, where $M$ is chromium or iron, precipitate along the grain boundaries and deplete the boundary region of chromium. In nitrogen strengthened steels, the carbides may contain nitrogen a 1 so. 


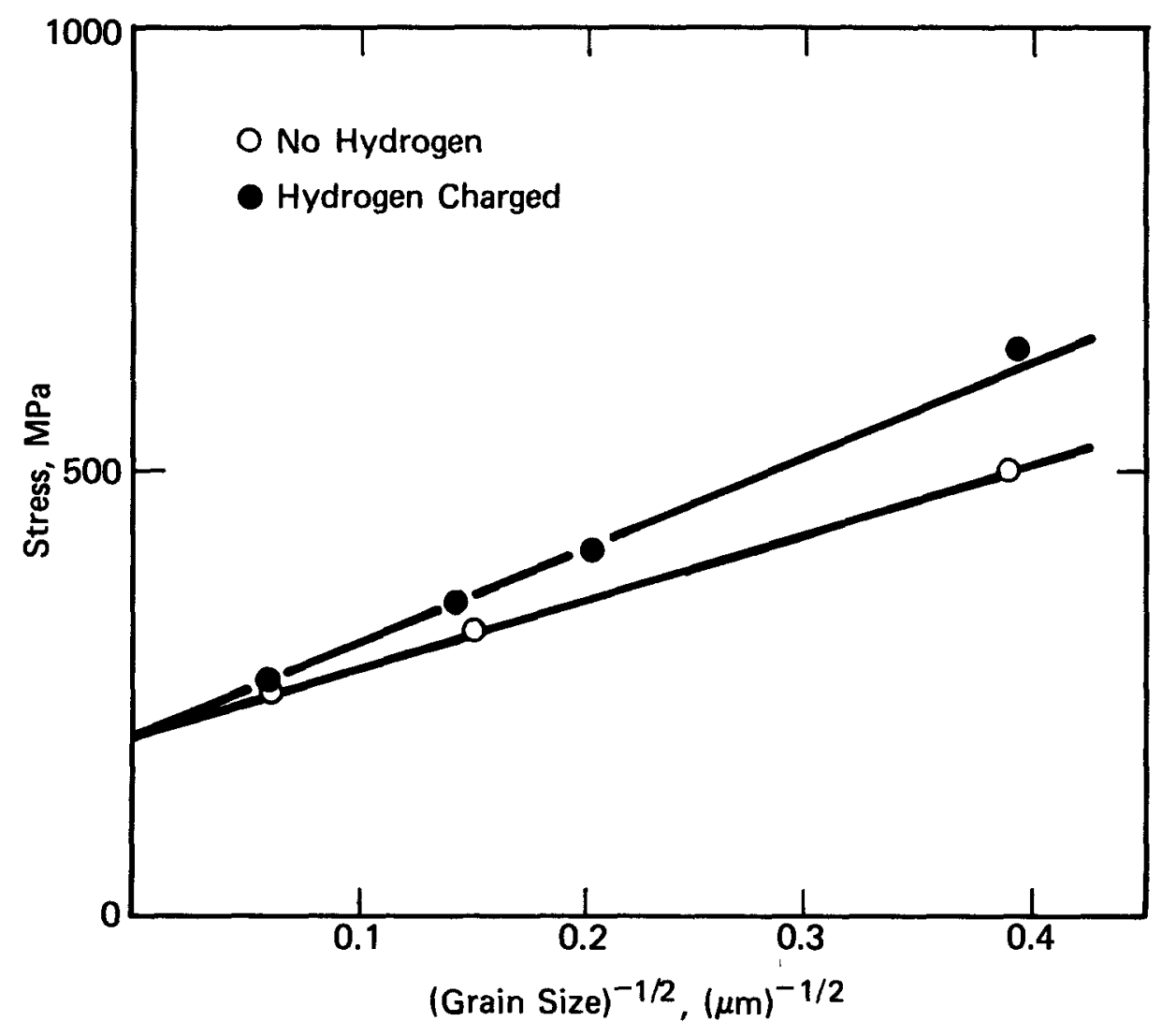

FIGURE 4. Hal1-Petch Plot for Tensile-Text Specimens of Type 304L Stainless Steel at a Plastic Strain $\varepsilon=0.05$ 


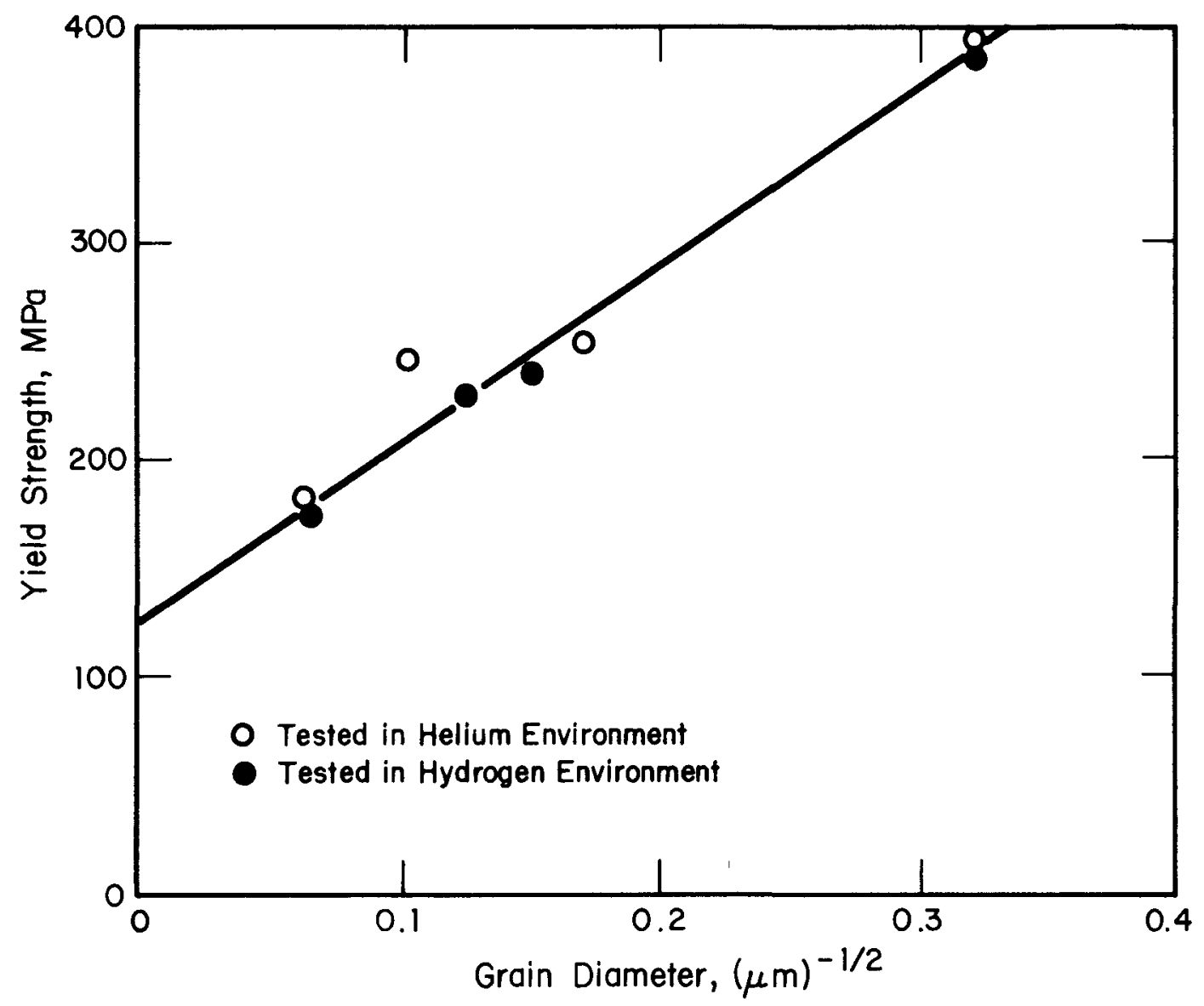

FIGURE 5. Ha11-Petch Plot of Yield Strength for Type 304L Stainless Steel Tested in in High-Pressure Helium or Hydrogen Environments 
The effects of sensitization anneals at about $920 \mathrm{~K}$ on hydrogen damage have been reported for Type $304,23304 \mathrm{~L}, 309 \mathrm{~S}, 24$ and Nitronic 40 stainless steels. These investigations of hydrogenassisted fracture of sensitized austenitic stainless steel do not present a consistent or uniform set of mechanical property data. Consequently, comparison of relative strength or ductility changes due to sensitization are limited. In those cases where data were collected, sensitization appears to lower the tensile strength of the alloys both for tests in air and in hydrogen. The ductility of sensitized specimens in hydrogen was less than that of the solutionannealed specimens except for Type $309 \mathrm{~S}$ steel, where no ductility change or intergranular fracture was observed. The anomalous behavior of sensitized Type 309S steel is not attributable to composition effects such as carbon/chromium ratio or carbon + nitrogen/ chromium ratio. Carbide precipitation was observed in all four alloys.

Hydrogen compatibility of precipitation hardenable alloys is sensitive to aging temperature and time. The fracture toughness of single-edge notched specimens of 17-4PH stainless steel varied substantially with aging. The most severe degradation occurred for the peak aged specimens. In the case of A-286, aging times of 4, 8 , and 16 hours at $993 \mathrm{k}$ resulted in small changes in fracture toughness and improved hydrogen compatibility for the shorter aging times.

\section{Mechanical Processing}

Parts for hydrogen service may be made from annealed or coldworked bar and cross-rolled plate, or HERF stock. Further coldworking may occur during fabrication. The various working processes introduce characteristic microstructural features, affect the mechanical properties, and may change susceptibility to hydrogen damage of the stainless steel.

Suceptibility to hydrogen damage observed in tensile tubes machined from cross-rolled plate was unchanged by prior cold-work of up to $25 \%$, Figures 6 and 7 . Specimens were filled with hydrogen at $69 \mathrm{MPa}$ pressure and stored 30 days at $430 \mathrm{~K}$ before tensile testing at room temperature. The bore of the specimen contained highpressure hydrogen during testing.

In the case of thin sheet $(0.1 \mathrm{~mm}$ thick), a progressive decrease in tensile ductility was found as prestrain was increased from 0 to about $12 \%$, Figure 7 .

In contrast, properties of annealed and $10 \%$ cold-worked sheet of Type 309S stainless steel were comparable. After three and a half months' exposure to hydrogen at $47.5 \mathrm{MPa}$ at $345 \mathrm{~K}$, tensile 


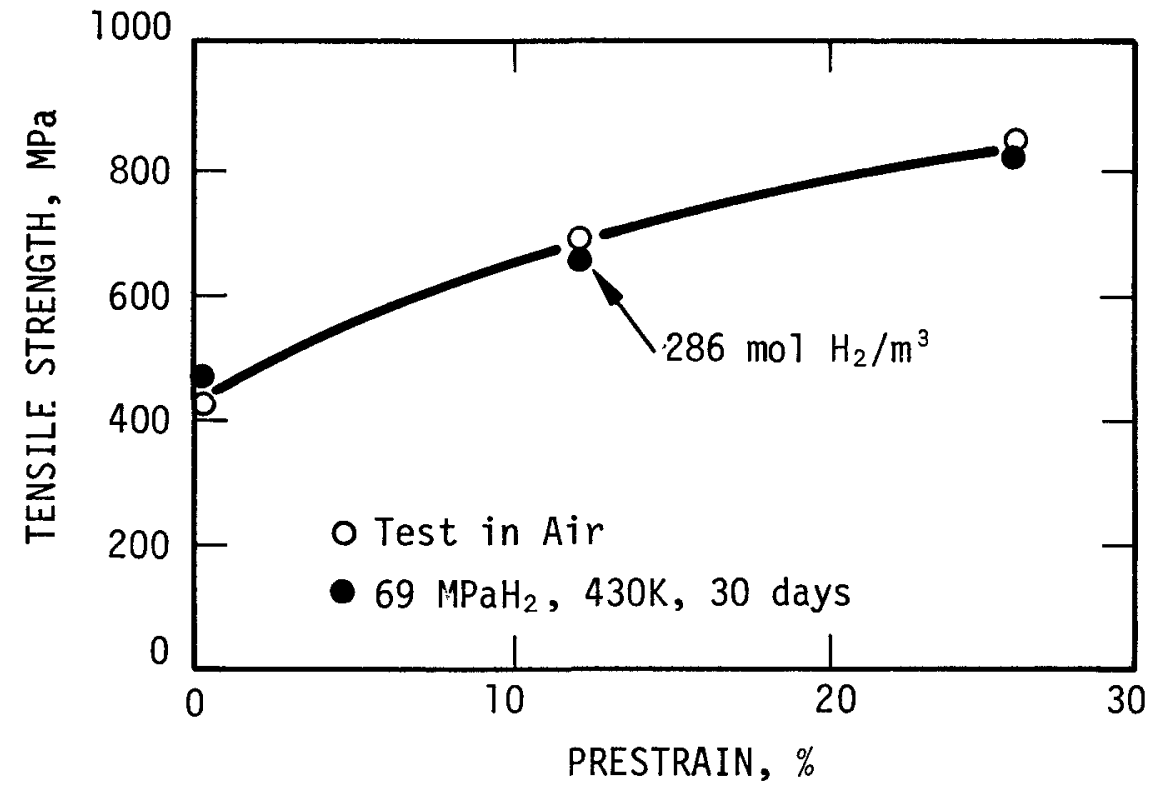

FIGURE 6. Effect of Prestrain on Tensile Strength of Type 304L Stainless Steel Tubes in Air or Hydrogen 


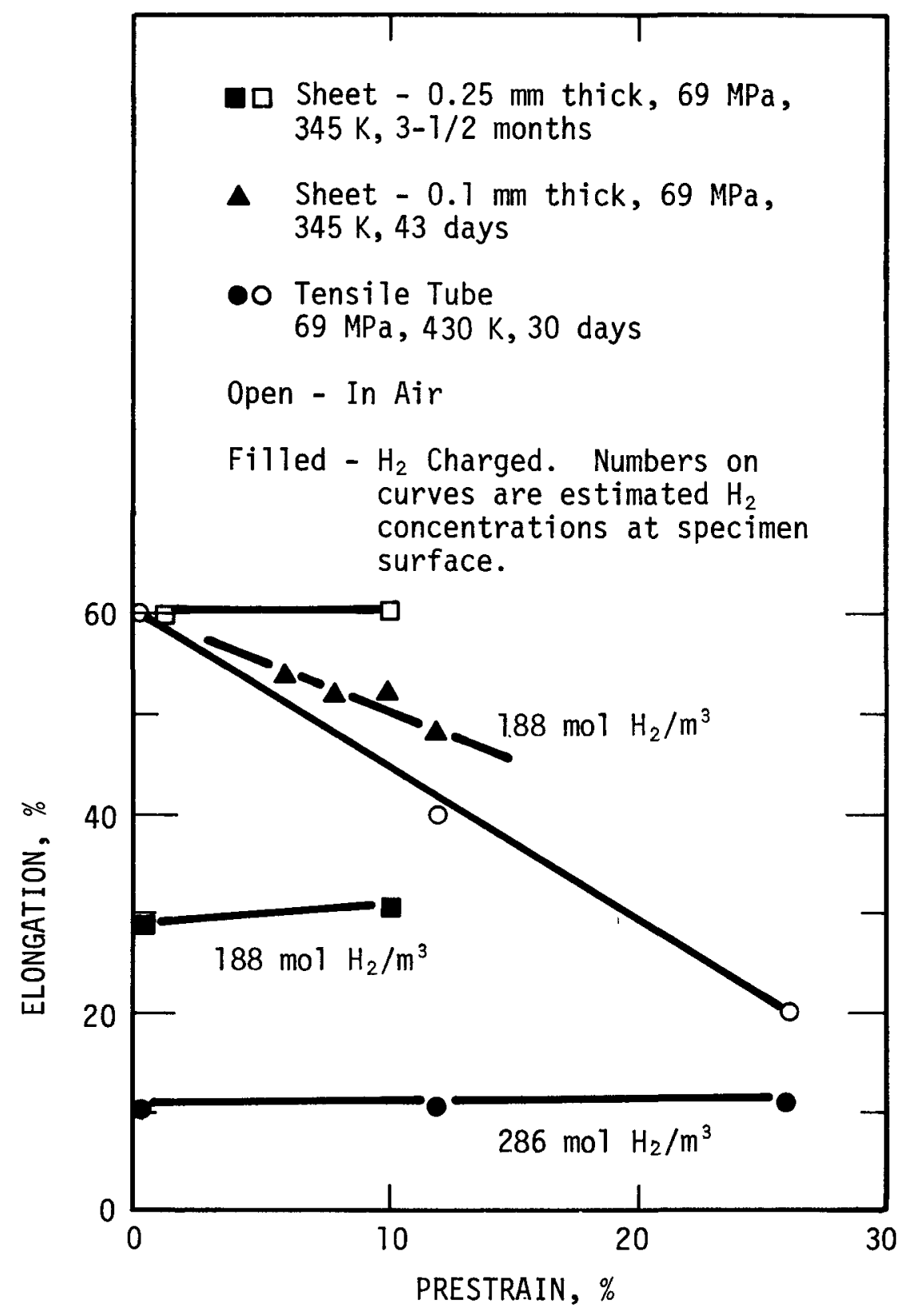

FIGURE 7. Effect of Prestrain on Elongation of Type 304L Stainless Steel in Air or Hydrogen 
strength was $625 \mathrm{MPa}$ for both alloys, and total elongations were 51 to $55 \%$ for the annealed sheet and 48 to $57 \%$ for the cold-worked sheet. Properties of annealed sheet were a $570 \mathrm{MPa}$ tensile strength and 59 to $64 \%$ elongation prior to hydrogen exposure.

A British study on two stainless steel compositions showed that cold work increased susceptibility to hydrogen damage, 25 Figure 8. These steels have no counterpart among commercial stainless steels in the United Stated. The results further demonstrate that the effect of cold-working is greater in the $12 \mathrm{Cr}-12 \mathrm{Ni}$ alloy than in the $23 \mathrm{Cr}-21 \mathrm{Ni}$ alloy. Martensite is formed during coldworking of the former alloy, but not the latter alloy, and may account for their difference in behavior.

Tensile test data show that HERF alloys are more resistant to environmental hydrogen damage than either annealed or cold-worked alloys, Table 3. A similar result is observed for thermally charged specimens tested at room temperature. At lower test temperatures, the HERF specimens of Type $304 \mathrm{~L}$ and Nitronic 40 stainless steels are only marginally better than annealed specimens in terms of ductility. Yield and tensile strengths are higher in the HERF alloys, therefore, on the basis of retained ductility for a given strength level, the HERF alloys are superior to annealed alloys.

Specimens made of Nitronic 40 cold worked $30 \%$ from HERF stock were slightly less ductile than specimens in the HERF condition during tests in high-pressure hydrogen, Figure 9. Tensile data also suggest a slight increase in susceptibility to hydrogen damage, Figure 10 .

HERF develops a distinctive deformation pattern in stainless steels which has its origins in segregation in the ingot, and rolling of the plate before HERF. The effect of this pattern on susceptibility to hydrogen damage was evaluated by the J-integral. $J_{m}$, the critical force at maximum load (area under load deflection curve), and tearing resistance $\mathrm{dJ} / \mathrm{da}$ (change in $\mathrm{J}$ with crack length, $a$, at maximum load), were evaluated for $V$-notch specimens of Type $304 \mathrm{~L}, \mathrm{~A}-286$, Nitronic 50 , and Nitronic 40 stainless steels machined from HERF bars. Notches were oriented as shown in Figure 11 with respect to the forging pattern and fatigue precracked at a maximum stress intensity of $44 \mathrm{MPa} \sqrt{\mathrm{m} \cdot}$ Specimens were tested in high-pressure helium or hydrogen and after prior exposure to deuterium at $69 \mathrm{MPa}$ pressure for seven days at $520 \mathrm{~K}$ or three weeks at $620 \mathrm{~K}$.

The deformation pattern caused by HERF processing affected $\mathrm{J}_{\mathrm{m}}$ but not $\mathrm{dJ} / \mathrm{da}$ for tests in high-pressure hydrogen or helium. The lowest values of $J_{m}$ were for notches parallel to the flow lines, an effect especially pronounced in A-286 and Nitronic ${ }^{\otimes} 50$ 


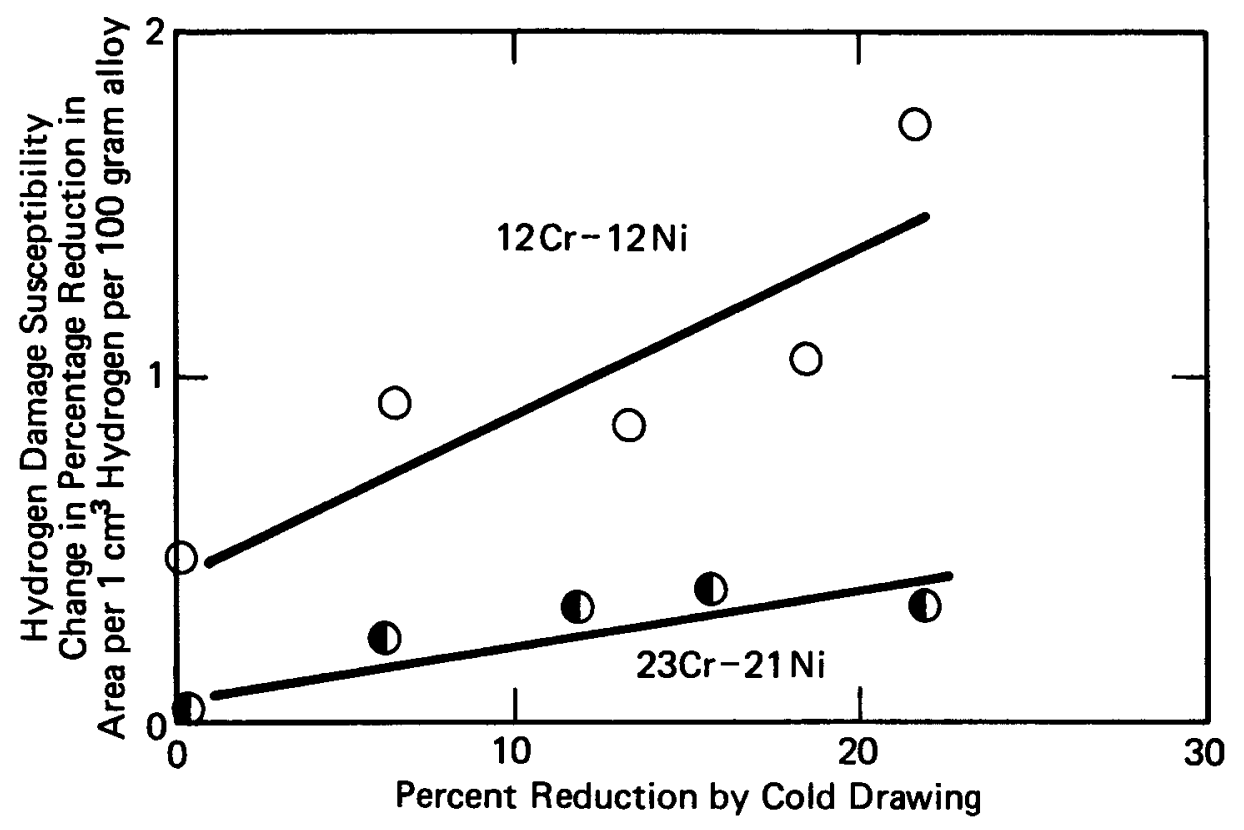

FIGURE 8. Effect of Prior Cold Work on Hydrogen Damage
Susceptibility of Stainless Steels 
TABLE 3

Mechanical Properties of HERF and Annealed Alloys in High-Pressure Gas

\begin{tabular}{|c|c|c|c|c|c|c|}
\hline & & Test* & Stren & 1, MPa** & Ducti & $=y \%$ \\
\hline Alloy & Condition & Environment & Yie1d & U1timate & Elong & $\mathrm{Ra}$ \\
\hline $304 \mathrm{~L}$ & Annealed & $\mathrm{He}$ & 186 & 565 & 74 & 81 \\
\hline & & $\mathrm{H}_{2}$ & 206 & 503 & 48 & 33 \\
\hline & HERF & $\mathrm{He}$ & 490 & 660 & 43 & $\begin{array}{l}77 \\
60\end{array}$ \\
\hline 310 & & & & & & \\
\hline 810 & 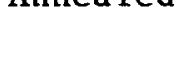 & $\mathrm{H}_{2}$ & 186 & 486 & 66 & 79 \\
\hline & HERF & $\mathrm{He}$ & 470 & 606 & 21 & 71 \\
\hline & & $\mathrm{H}_{2}$ & 460 & 620 & 24 & 70 \\
\hline Nitronic 40 & Annealed & $\mathrm{He}$ & 352 & 689 & 58 & 78 \\
\hline & & $\mathrm{H}_{2}$ & 358 & 696 & 59 & 77 \\
\hline & HERF & $\mathrm{He}$ & 570 & 780 & 34 & 75 \\
\hline & & $\mathrm{H}_{2}$ & 570 & 790 & 30 & 73 \\
\hline$A-286$ & Annealed & $\mathrm{He}$ & 724 & 1117 & 26 & 47 \\
\hline & & $\mathrm{H}_{2}$ & 710 & 1131 & 34 & 49 \\
\hline & HERF & Air & 875 & 1060 & 24 & 29 \\
\hline & & $\mathrm{H}_{2}$ & 834 & 1110 & 27 & 32 \\
\hline CG27 & Annealed & $\mathrm{He}$ & 806 & 1165 & 29 & 26 \\
\hline & & $\mathrm{H}_{2}$ & 855 & 1117 & 10 & 12 \\
\hline & HERF & $\mathrm{He}$ & 1070 & 1385 & 12 & 12 \\
\hline & & $\mathrm{H}_{2}$ & 1034 & 1138 & 1 & 3 \\
\hline
\end{tabular}

* $\mathrm{He}=69 \mathrm{MPa} \mathrm{He} ; \mathrm{H}_{2}=69 \mathrm{MPa} \mathrm{H}_{2} ;$ Air $=0.1 \mathrm{MPa}$ air.

** Yield $=$ True stress at $5 \%$ strain.

Ultimate $=$ True stress at maximum load. 


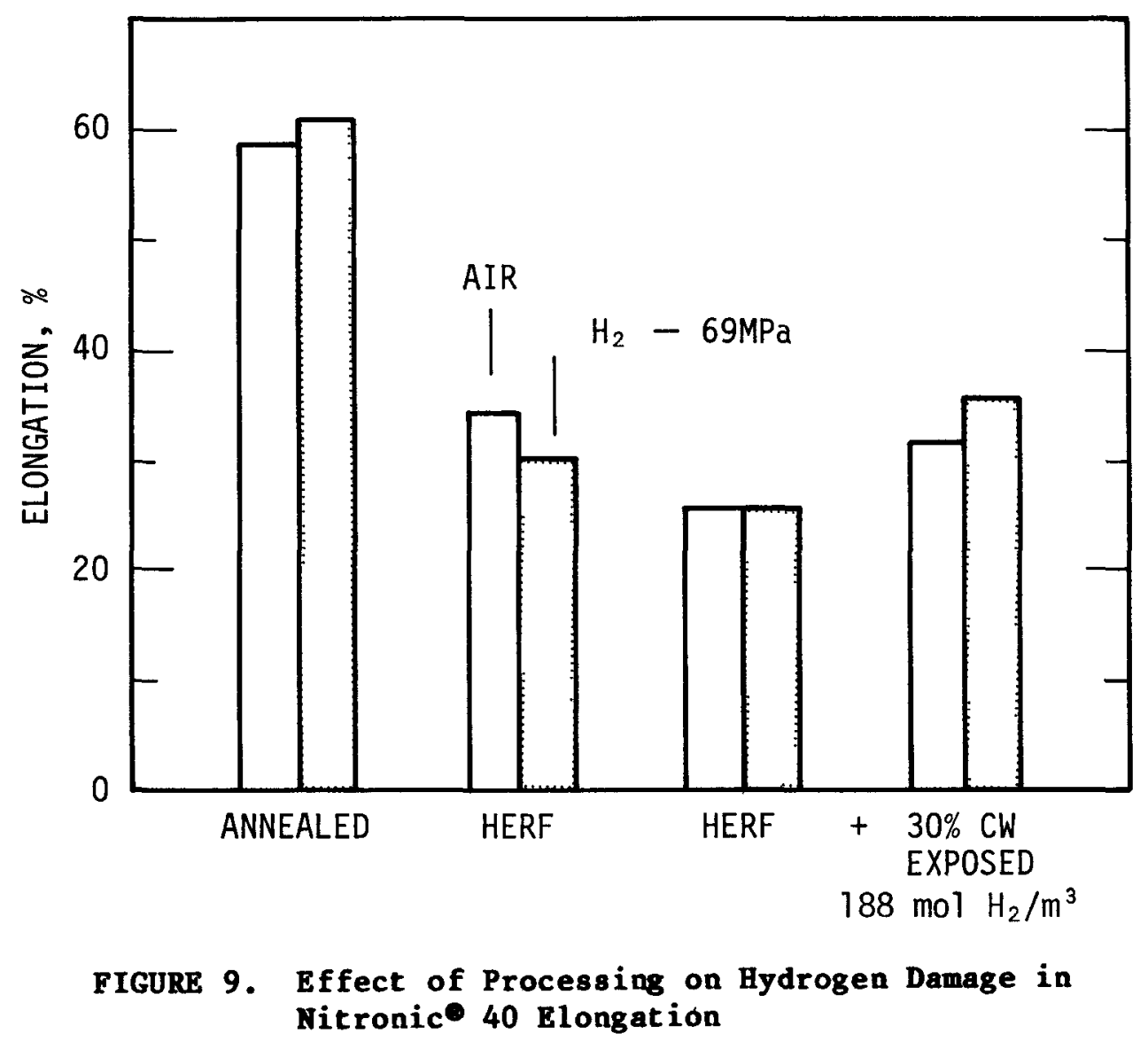




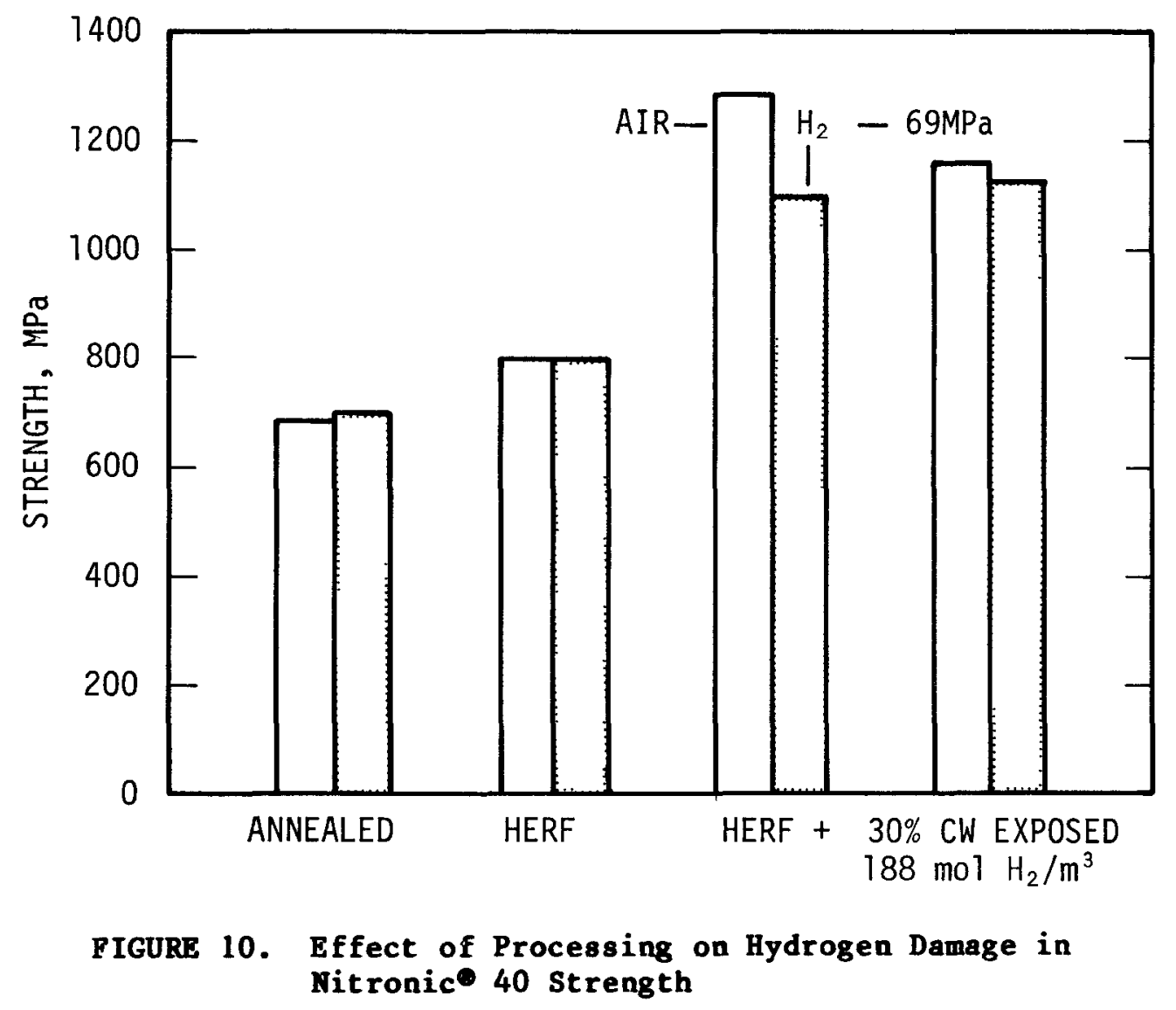




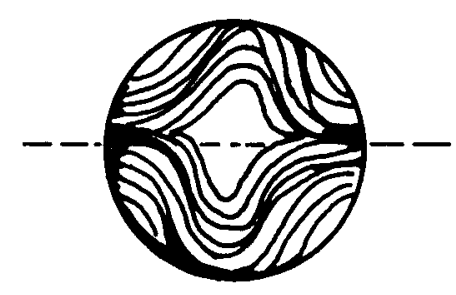

A. Cross Section of Bar Showing Forging Flow Lines

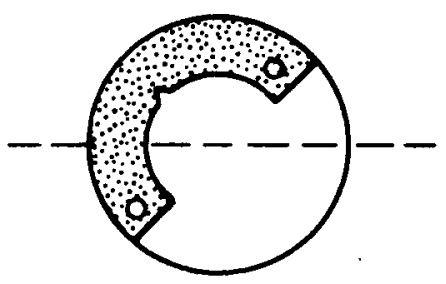

.C. $45^{\circ}$ Orientation of Notch

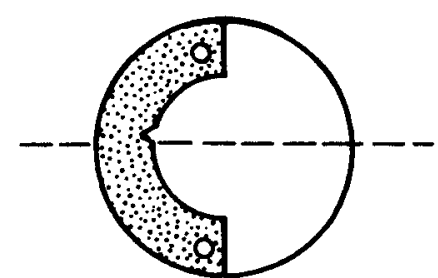

B. Parallel Orientation of Notch

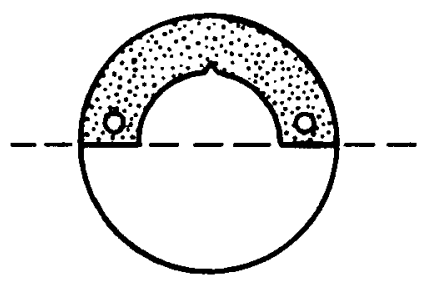

D. $90^{\circ}$ Orientation of Notch

FIGURE 11. Orientation of V-Notch with Respect to Forging Flow Lines in Tensile-Test Specimens Machined

from Bass of HERF Stainless Steels 
stainless steel. However, hydrogen damage as measured by $\mathrm{J}_{\mathrm{m}}$ was greatest for notches $90^{\circ}$ to the flow pattern except for Nitronic ${ }^{\circledR} 40$, where damage was greater for 0 and $45^{\circ}$ orientations than for the $90^{\circ}$ orientation. $\mathrm{dJ} / \mathrm{da}$ was affected relatively less by hydrogen damage than $J_{\mathfrak{m}}$.

Changes in $\mathrm{J}_{\mathrm{m}}$ and $\mathrm{dJ} / \mathrm{da}$ caused by hydrogen charging prior to testing were alloy and orientation dependent. Hydrogen exposure of A-286 stainless steel decreased $J_{m}$ and $d J / d a$. For Type $304 \mathrm{~L}$ stainless steel, $\mathrm{dJ} / \mathrm{da}$ was unaltered and $\mathrm{J}_{\mathrm{m}}$ was decreased for $45^{\circ}$

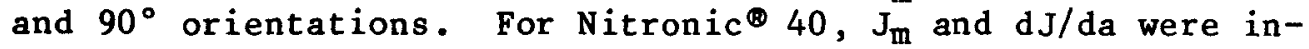
creased by hydrogen exposure prior to testing, possibly because of microstructural changes that occurred during hydrogen charging.

\section{Effect of Martensite}

The above results show that the effect of cold work on hydrogen damage is variable and may be linked to martensite. A study was made of the relation between martensite and hydrogen damage. Martensite was formed in annealed specimens of Type $304 \mathrm{~L}$ austenitic stainless steel either by thermal or mechanical treatment. Specimen surfaces were electropolished to remove the deformed outer layer that is generated during machining. This layer contains some $\alpha^{\prime}$-martensite in Type 304L stainless steel. The volume fracture martensite formed by the various treatments was not measured directly, but the relative quantity of martensite was indicated by the magnetic response of the specimens. The specimens were pulled to failure in a high-pressure ( $69 \mathrm{MPa}$ ) hydrogen atmosphere following thermal or mechanical treatment. Thermal treatment consisted of quenching specimens to $77 \mathrm{~K}$ in liquid nitrogen and holding at temperature for 10 minutes. Three mechanical treatments were used: cold reduction of 12 or $26 \%$ by cold swaging, torsional strain ( $70-$ in. 1b) at room temperature or $77 \mathrm{~K}$, and $10 \%$ tensile strain at room temperature or $77 \mathrm{~K}$. Tensile strain at room temperature caused some transformation to $\varepsilon$-phase and $\alpha^{\prime}$-martensite formation.

Uniform elongation and plastic strain to failure for each of the treatments are reported in Table 4. Magna-gage (American Instrument Company) readings following treatment and prior to tensile testing are given. Several important observations are apparent from inspection of the table: ductility is reduced when martensite is present prior to testing; hydrogen embrittlement does not correlate simply with volume fraction martensite, as the highest Magna-gage ${ }^{\circledR}$ readings (B) do not correspond to lowest ductility (F); the presence of an applied stress during the quench to $77 \mathrm{~K}$ suppresses transformation to $\alpha^{\prime}$-martensite ( $B, C$, and $D$ ); the radial distribution of the martensite and possibly its orientation relative to the applied stress affect hydrogen embrittlement ( $B, C, F)$. 


\section{TABLE 4}

Effect of Hartensite on Subsequent Environmental Hydrogen Damage in Type 304L Stainless Steel

\section{Treatment}

A. Annealed-electropolished

B. Immersed in liquid nitrogen for $10 \mathrm{~min}$

C. Applied torque and immersed in liquid nitrogen for $10 \mathrm{~min}$

D. Applied tensile stress and immersed in liquid nitrogen for $10 \mathrm{~min}$

E. $10 \%$ plastic strain at room temperture

F. $7.9 \mathrm{Nm}$ torque at room temperature
Ductility

Uni form

Elongation

79

Fracture

Magna-gage

Strain

1.31

Reading

51

0.45

$90-100$

58

0.38

30

60

0.42

13

75

1.11

0

26

0.24

30 


\section{Environmental Variables Affecting Hydrogen Damage}

Degradation of mechanical properties by hydrogen depends upon several factors external to the specimen: temperature, hydrogen pressure, stress state, and strain rate. These factors control how much hydrogen enters the material and how rapidly solution and distribution of hydrogen occur within the specimen. Hydrogen redistribution to regions of high stress and the hydrogen diffusion rate relative to any imposed deformation rate directly influence severity of hydrogen damage.

\section{Hydrogen Pressure}

The severity of hydrogen damage in any alloy has been shown to relate directly to hydrogen pressure whether for hydrogen-charged specimens or for testing in a hydrogen environment. As seen in Figure 12, tensile ductility of Type 304L stainless steel falls off rapidly as hydrogen pressure is increased up to $14 \mathrm{MPa}$ and then more slowly up to $69 \mathrm{MPa}$. Tensile strength of notched and fatigue cracked specimens also decreases from 780 to $660 \mathrm{MPa}$ as the hydrogen pressure increases from 0.1 to $6.9 \mathrm{MPa}$. For most other alloys, testing has been at fixed hydrogen pressure of $69 \mathrm{MPa}$, and data do not exist for other pressures.

A pressure effect is seen in both tensile and threshold stress intensity data for Incone ${ }^{\oplus} 718.26$ Tensile strength and reduction-in-area decrease linearly with square root of hydrogen pressure at pressure above about $10 \mathrm{MPa}$. The stress intensity at crack arrest for wedge opening loaded specimens at room temperature decreased from $90 \mathrm{MPa} \sqrt{\mathrm{m}}$ to about $42 \mathrm{MPa} \sqrt{\mathrm{m}}$ for hydrogen pressures of $20 \mathrm{MPa}$ and higher.

Hydrogen gas pressures of $69 \mathrm{MPa}$ have no significant effect on the mechanical properties of Type 310 stainless steel. However, severe hydrogen damage can be induced in Type 310 stainless steel by cathodic charging where the effective hydrogen pressure is extremely high $(\gg 200 \mathrm{MPa}) .27$

\section{Test Temperature}

Hydrogen damage in stainless steels has been shown to be temperature dependent for alloys where appropriate testing has been done. The most severe damage occurs at 220-280 $\mathrm{K}$. As seen in Figure 13, tensile ductility in several alloys is a minimum in this temperature range. There does not appear to be any significant difference between $\mathrm{Fe}-\mathrm{Cr}-\mathrm{Ni}$ and $\mathrm{Fe}-\mathrm{Cr}-\mathrm{Ni}-\mathrm{Mn}$ alloys in this respect, Figure 14. Furthermore, the minimum ductility ratio is observed in this same temperature range even in alloys which are affected very 


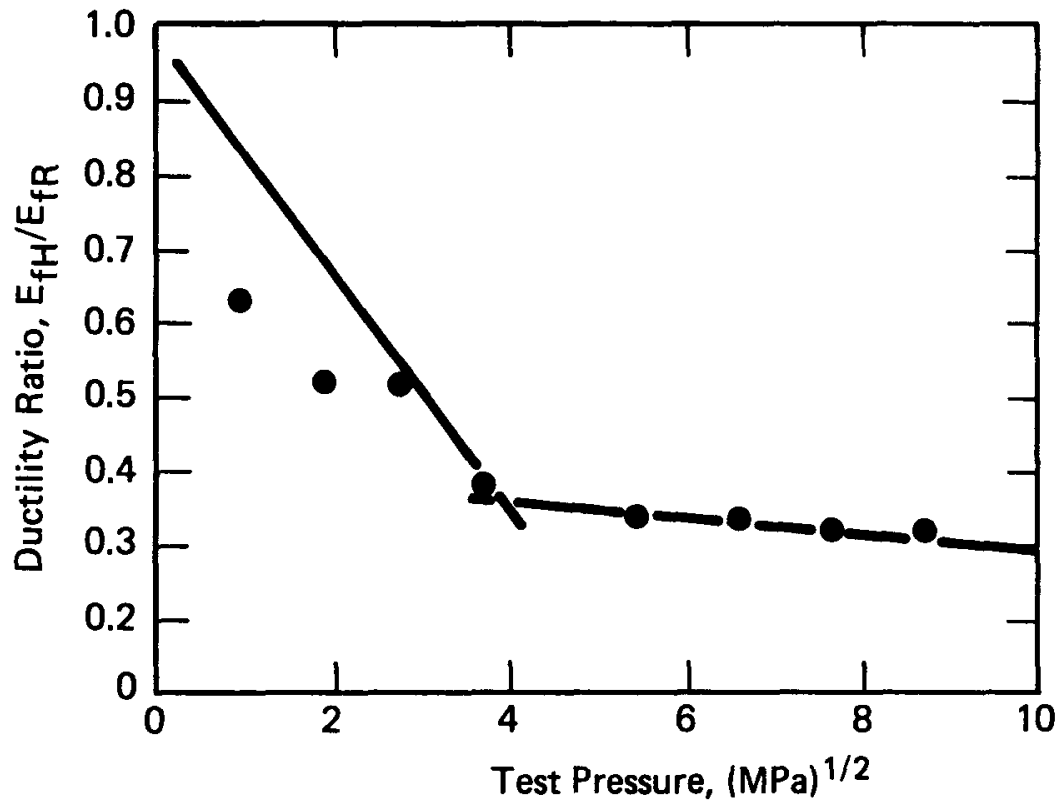

FIGURE 12. Effect of Hydrogen Pressure on Ductility of Type 304L Stainless Steel Tested to Fracture in Hydrogen at Room Temperature 


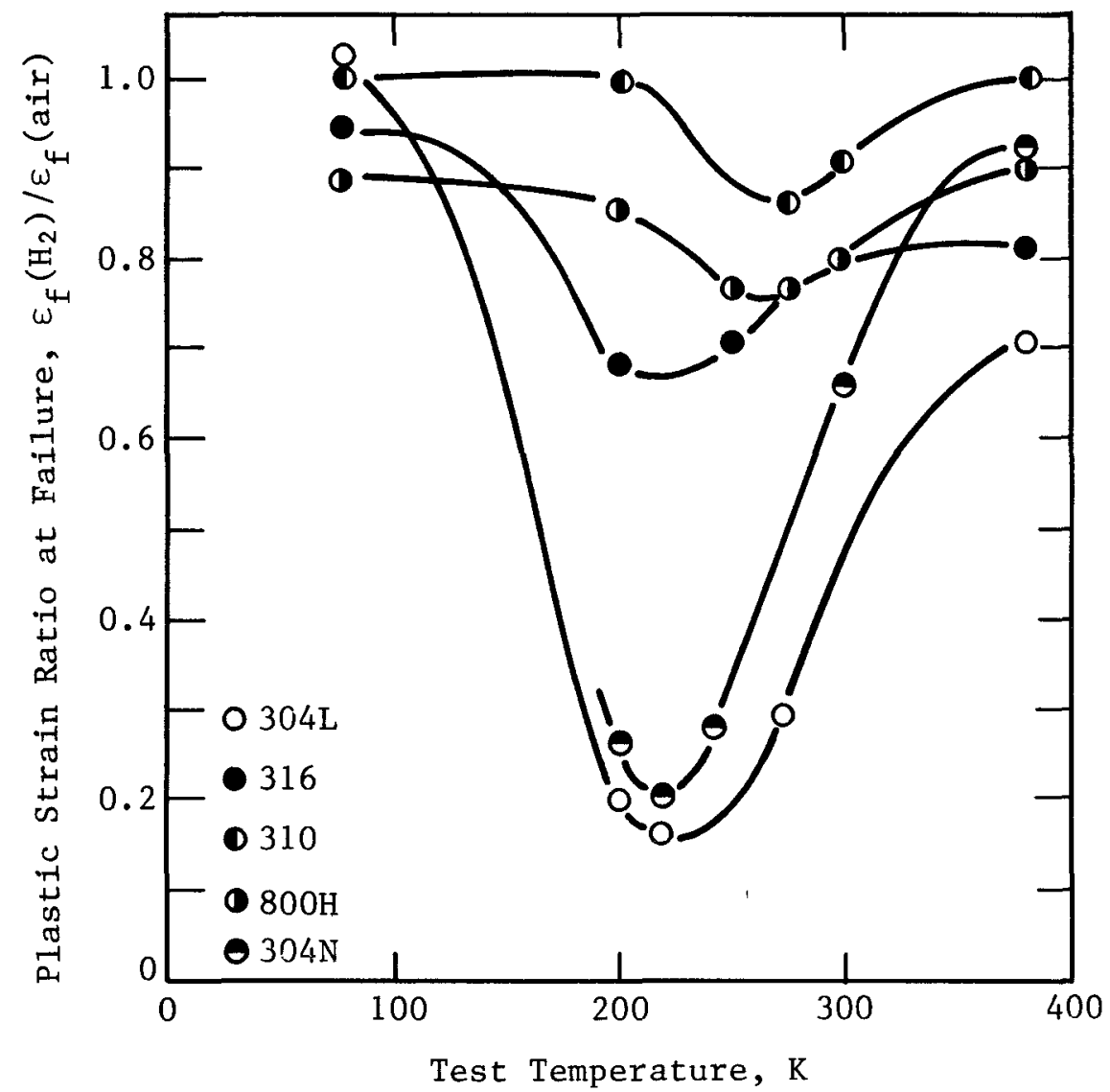

FIGURE 13. Ductility Minima in Fe-Cr-Ni Alloys Charged with Deuterium at $69 \mathrm{MPa}$ and $620 \mathrm{R}$ for Three Weeks 


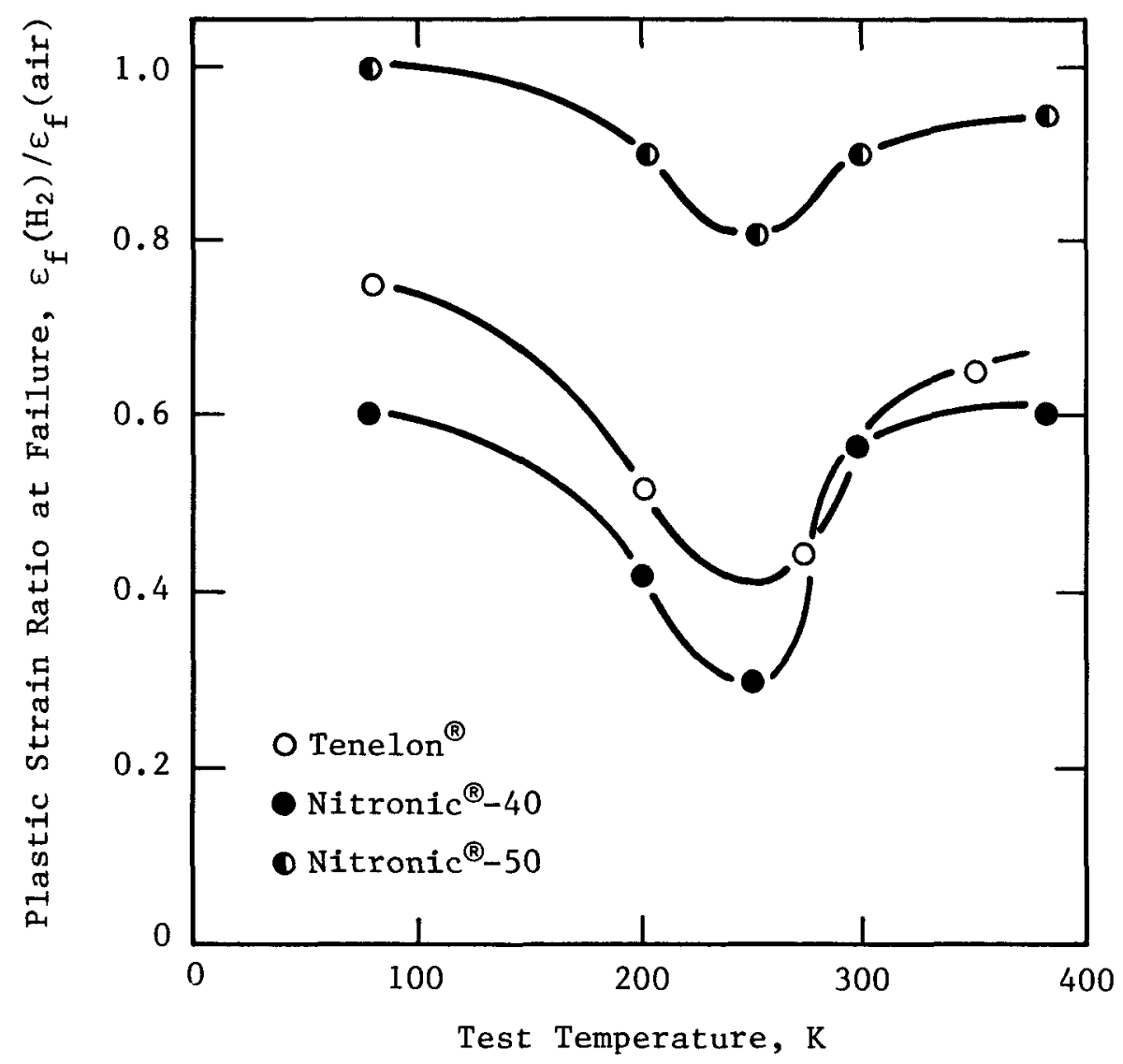

FIGURE 14. Ductility Minima in Fe-Cr-Mn-Ni Alloys Charged with Deuterium at $69 \mathrm{MPa}$, and $620 \mathrm{~K}$ for Three Weeks 
little by hydrogen, such as Nitronic 50, Type 310, and Type 316 stainless steels. It is not known yet if the threshold stress intensity for sustained load crack growth in these stainless steels follows a similar temperature dependence. However, the data for Incone1® 718 (Huntington Alloys) lead to the inference that $k_{t h}$ and tensile ductility have a similar temperature dependence. 26

The general trends of both test temperature and nickel content on hydrogen damage are illustrated in Figure 15 for three highpurity alloys of constant chromium content (about $18 \%$ ). Isoductility lines sketched in this figure outline a region of significant hydrogen damage $\left(\varepsilon_{\mathrm{p}}<0.5\right)$ at about $200-240 \mathrm{~K}$ that extends to $14 \%$ nickel.

Although most materials show a hydrogen-induced ductility minimum, the temperature of the minimum is not always around $220-280 \mathrm{~K}$ as in stainless steels. Pure nickel displays ductility minima around room temperature, at $220 \mathrm{~K}$ and at $150 \mathrm{~K}$, but the $220 \mathrm{~K}$ minimum is the only one to persist over a wide range of strain rates $\left(10^{-1}\right.$ to $\left.10^{-5} \mathrm{sec}^{-1}\right) .15$ Maximum hydrogen damage in Incone ${ }^{\otimes}$ 718 is at room temperature as measured by ductility, notched tensile strength, and threshold stress intensity. 26

Strain-induced martensite forms during low-temperature deformation of many austenitic stainless steels which are nominally stable at room temperature. For a given alloy, there is a temperature designated $M_{d}$, above which no martensite forms on deformation and below which deformation produces martensite. The amount of transformation per unit strain increases as the temperature is lowered below $M_{d}$. Table 5 lists approximate $M_{d}$ temperatures for several of the austenitic steels that have been investigated. The appearance of brittle fracture and degradation of mechanical properties does not correlate with formation of strain-induced martensite. In particular, Type 316 stainless steel does not show a significant change in fracture strength or fracture mode between $250 \mathrm{~K}$ (no martensite) and $200 \mathrm{~K}$ (martensite present).

Magnetic measurements on specimens of Type 304L stainless steel strained incrementally at $200 \mathrm{~K}$ show that hydrogen suppresses formation of strain-induced martensite, Figure 16. However, hydrogen appears to enhance martensite formation during deformation at 250 and $298 \mathrm{~K}$. Suppression of martensite formation was seen also in Tenelon ${ }^{\oplus}$ at $200 \mathrm{~K}$ and Nitronic ${ }^{\oplus} 40$ at $78 \mathrm{~K}$, Figure 17 .

\section{Stress State and Strain Rate}

Plastic deformation and fracture characteristics are affected by stress state and strain rate. Severity of hydrogen damage, 


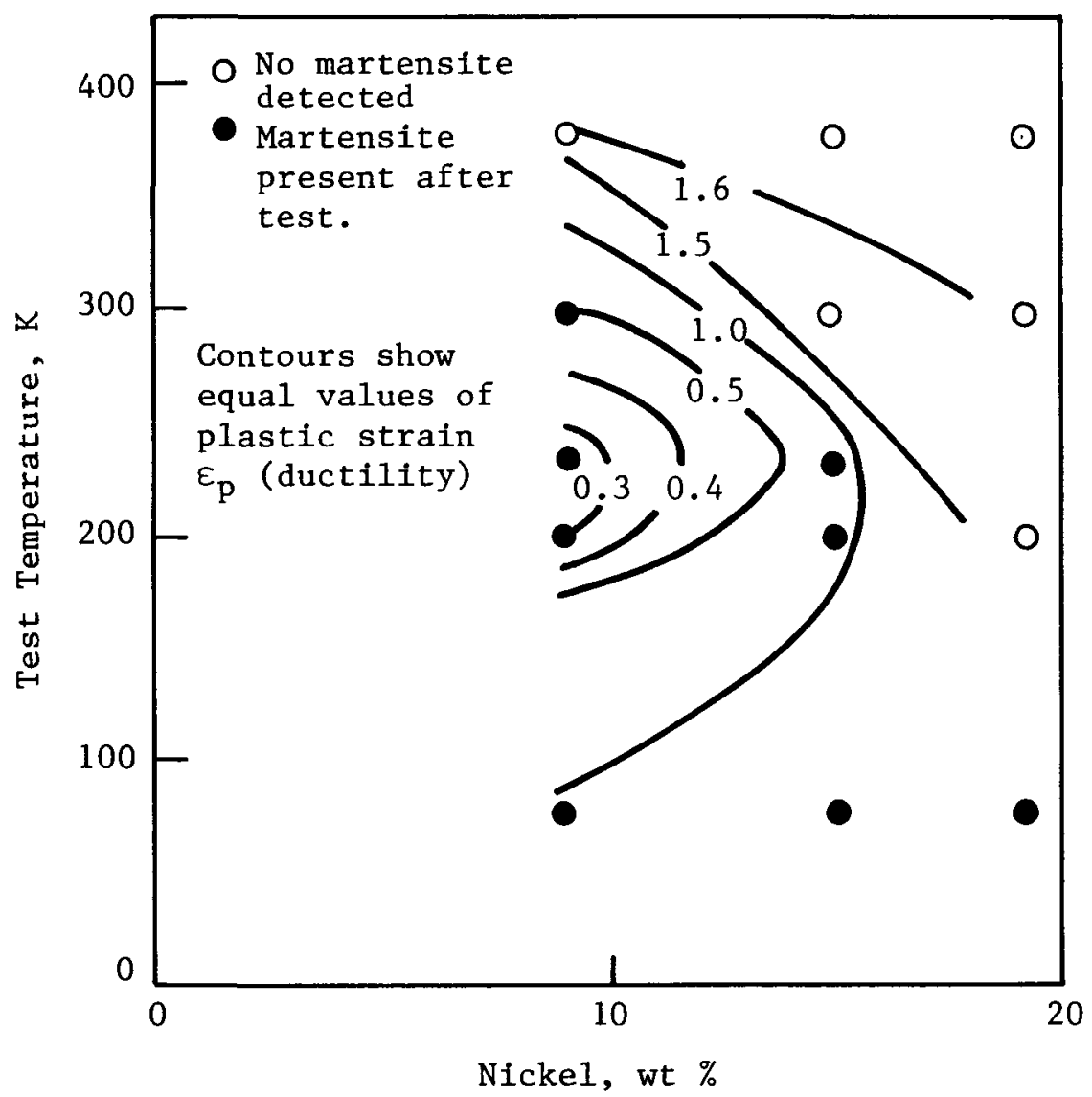

FIGURE 15. Isoductility Diagram for

Hydrogen-Charged $\mathrm{Fe}-\mathrm{Cr}-\mathrm{Ni}$ Alloys 
TABLE 5

Temperatures for Strain-Induced Martensite Formation

\begin{tabular}{lll} 
Alloy* & \multicolumn{1}{c}{$M_{\mathrm{d}}$ Temp, K } \\
\cline { 1 - 2 } $304 \mathrm{~L}$ & 350 \\
310 & $<4$ \\
316 & 220 \\
I800H & $<78$ \\
Tenelon & $200 *$ \\
Nitronic 40 & $\sim 100$ \\
Nitronic 50 & $\sim 150$ \\
A & $>370$ \\
B & 250 \\
C & 150 \\
& \\
* Martensite forms at temperatures near 200 K, \\
but not at either higher or lower temperatures.
\end{tabular}




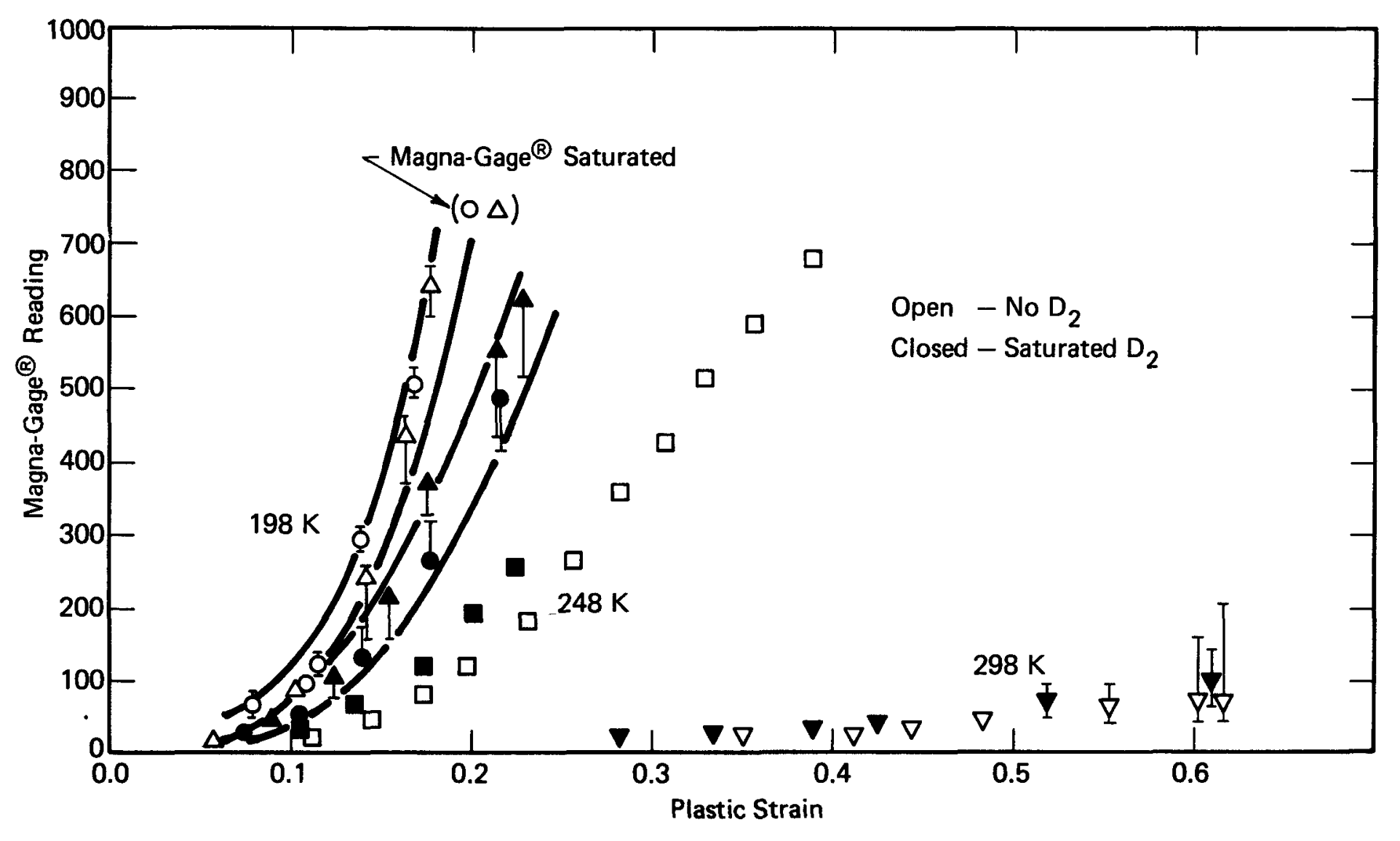

FIGURE 16. Effect of Hydrogen on Strain-Induced Martenite

Formation in Type 304L Stainless Steel 


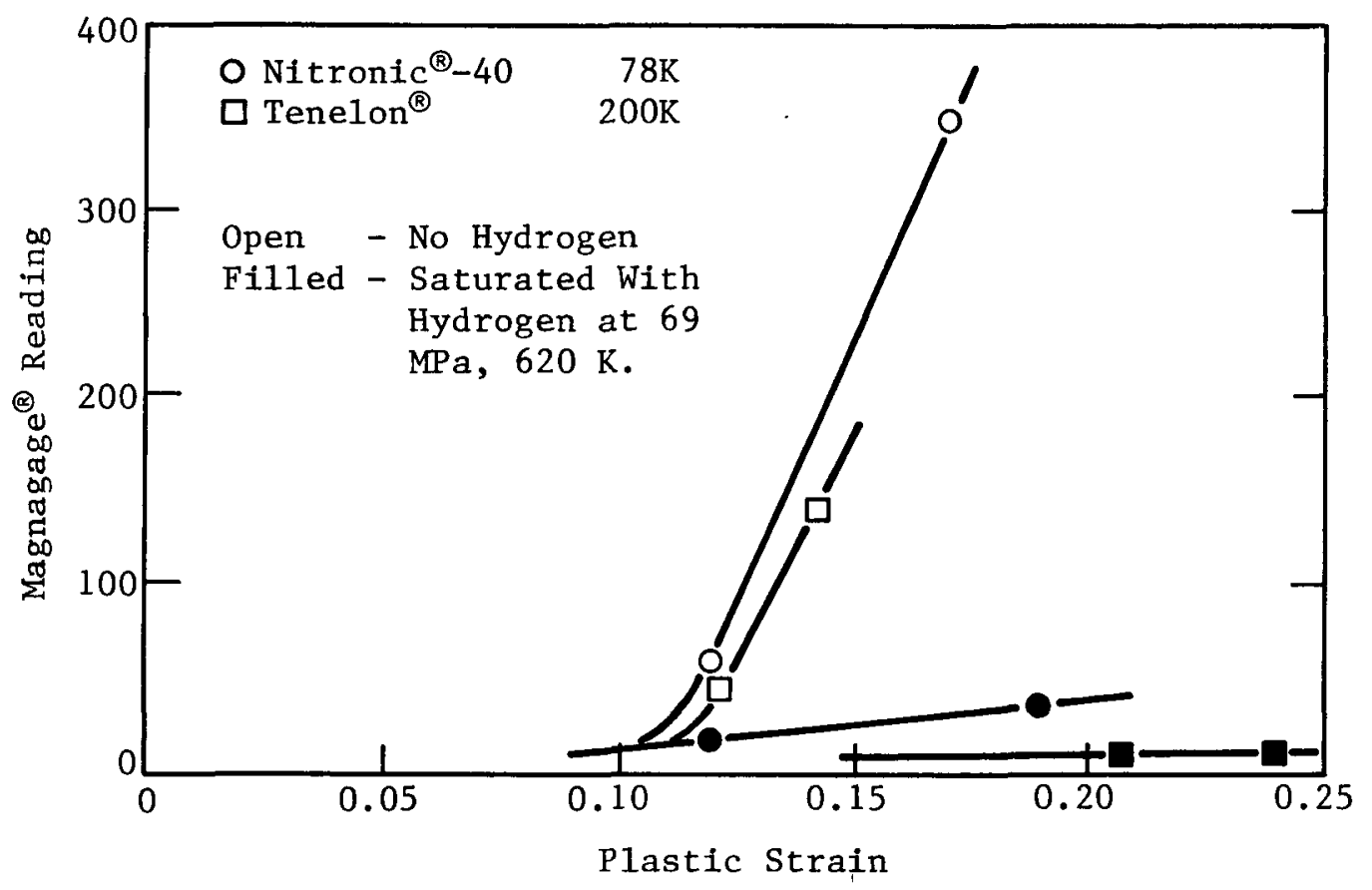

FIGURE 17. Effect of Hydrogen on Strain-Induced Martenite Formation in Tenelon ${ }^{\bullet}$ and Nitronic 40 
therefore, is also affected by stress state and strain rate. Different test methods may assess hydrogen degradation of mechanical properties differently, depending upon how stress state and strain rate influence hydrogen interactions with the alloys.

A biaxial stress state occurs during burst testing of discs. Hydrogen environment damage may be assessed by pressurizing discs of the same material with helium or hydrogen gas and measuring the burst pressure. 28 A ratio of burst pressures of one indicates no hydrogen damage, whereas ratios greater than one indicate hydrogen damage with severity of damage increasing as the ratio increases. Stee1s such as $A-286$, Type 310 , and Type 316 are relatively immune to hydrogen damage in this test; CG-27 behaves poorly; and Type 304 or $304 \mathrm{~L}$ are variable, depending upon the treatment prior to testing. The ranking of the alloys in the disc burst test is generally the same as for notch tensile tests in helium and hydrogen for a pressure of $69 \mathrm{MPa}$.

Notch Tensile Tests. Stress concentration and plastic constraint at the root of a notch can increase the severity of hydrogen damage under some circumstances. Notched specimens of Type $304 \mathrm{~L}$ and Nitronic 40 stainless steels tested in high-pressure hydrogen at room temperature illustrate the notch effect. The strength and ductility of the notched specimens are degraded more than that of the smooth specimens, Figures 18 and 19 . In contrast, ductility loss in notched specimens of hydrogen-charged Type 304L stainless steel was less than in smooth specimens, Table 6 . However, absolute ductility of the notched specimens is less than for smooth specimens. Hydrogen charged specimens of Nitronic 40 were more severely damaged when notched than when smooth, as was the case for tests in a hydrogen environment.

J-Integral Analysis. C-shaped and notched specimens were fatigue cracked and then tested in hydrogen or helium at $69 \mathrm{MPa}$ pressure. Susceptibility to environmental and internal hydrogen damage was evaluated by comparing J-integral values at maximum load $\left(J_{m}\right)$ and $d J / d a$ for four stainless steels machined from HERF bar stock. Ranking of the alloys was not consistent and depend on which specimen orientation was chosen for the comparison (Table 7).

Based on plastic strain to failure (reduction in area), HERF Type $304 \mathrm{~L}$ stainless steel is more susceptible to environmental hydrogen damage than HERF Nitronic $\$ 40$ stainless steel in direct opposition to the ranking based on $\mathrm{J}_{\mathrm{m}}$. These measures of hydrogen damage are biased differently, however, with respect to deformation and fracture. $J_{m}$ depends on flow stress and plastic strain up to the point where crack advance is assumed to begin. Plastic strain to failure, on the other hand, is affected strongly by the ability of the alloy to neck down without breaking and is effectively sampling a region of deformation not included in $J_{m}$. 


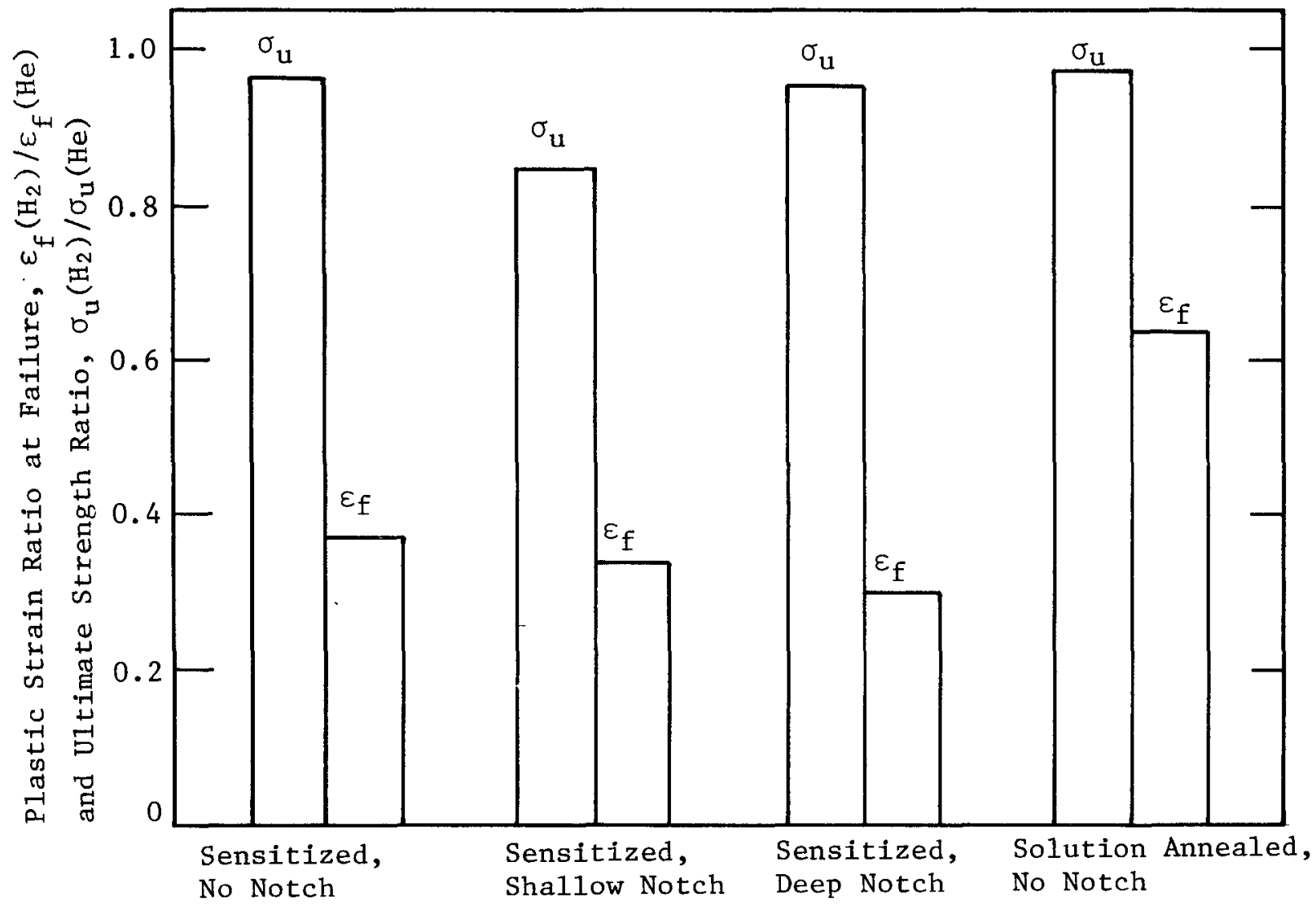

FIGURE 18. Relative Effect of Hydrogen on Properties of Sensitized Type 304L Stainless Steel 


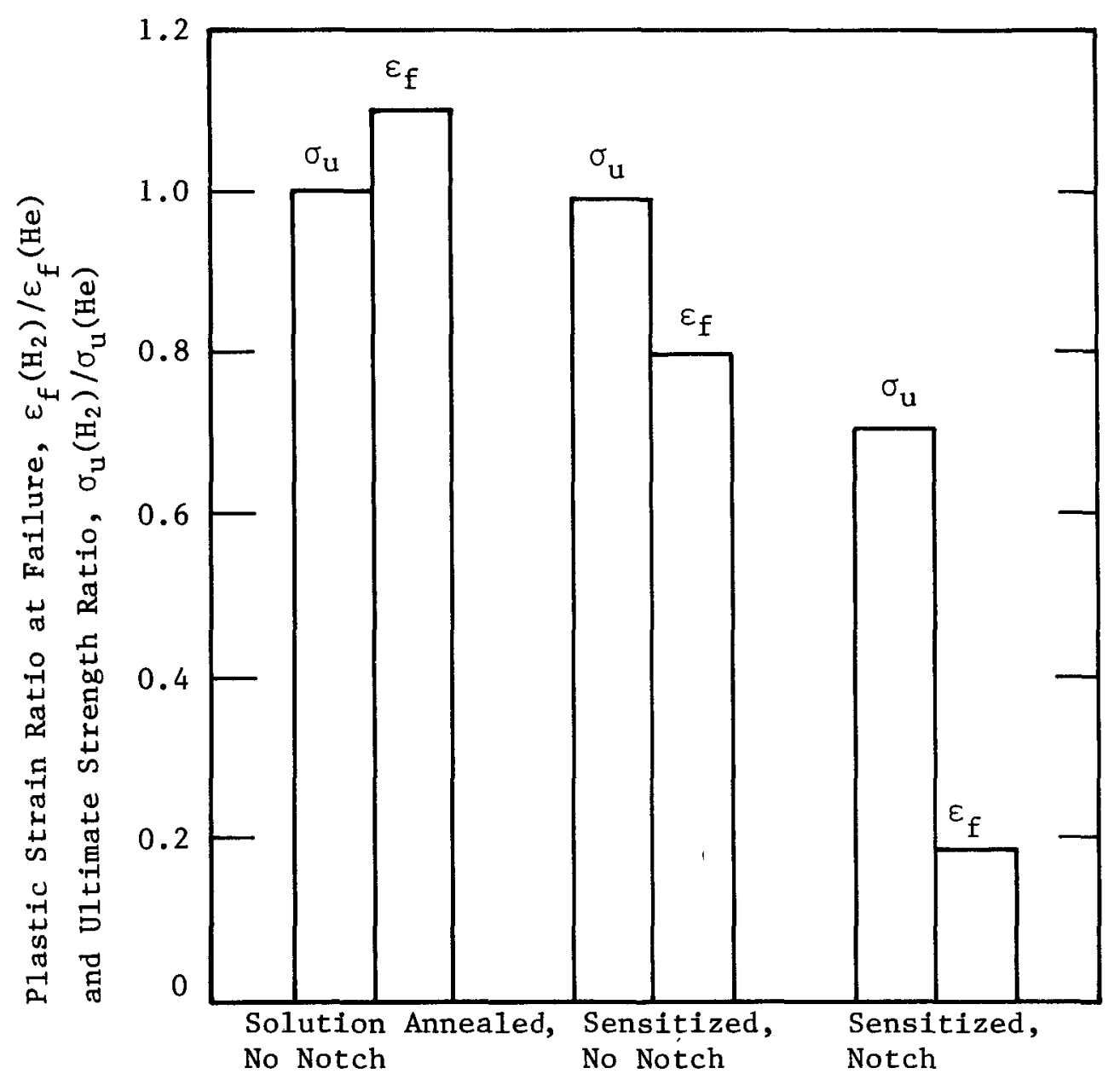

FIGURE 19. Environmental Hydrogen Damage in Nitronic 40 Stainless Steel at Room Temperature 
TABLE 6

Effect of Hydrogen Charging on Tensile Properties of Type 304L Stainless Steel

\begin{tabular}{llll} 
Condition & Specimen & $\begin{array}{l}\text { Nominal Tensile } \\
\text { Strength, MPa }\end{array}$ & $\begin{array}{l}\text { Plastic } \\
\text { Strain } \\
\text { To Failure }\end{array}$ \\
\cline { 1 - 1 } As received & $\begin{array}{lll}\text { Smooth } \\
\text { Notch }\end{array}$ & 600 & 1.50 \\
Annealed* & Smooth & 600 & 0.30 \\
Hydrogen charged** & Notch & 710 & 1.43 \\
& Smooth & 530 & 0.24 \\
& Notch & 580 & 0.37 \\
& & & 0.13
\end{tabular}

* Annealed 200 days at $380 \mathrm{~K}$ in argon.

** Exposed to hydrogen gas at $69 \mathrm{MPa}$ for 200 days at $380 \mathrm{~K}$.

TABLE 7

Ranking of Hydrogen Compatibility (HERF Stainless Steels)

\begin{tabular}{|c|c|c|}
\hline $\mathrm{J}_{\mathrm{m}}$ & $\mathrm{dJ} / \mathrm{da}$ & $\begin{array}{l}\text { Tensile* } \\
\text { Ductility }\end{array}$ \\
\hline$A-286 * *$ & $\begin{array}{l}\text { A-286 } \\
\text { Nitronic } 40 * *\end{array}$ & Nitronic 40 \\
\hline $\begin{array}{l}304 \mathrm{~L} \\
\text { Nitronic } 40\end{array}$ & Nitronic $\$ 50 * *$ & $304 \mathrm{~L}$ \\
\hline Nitronic $50 * *$ & $304 \mathrm{~L}$ & \\
\hline
\end{tabular}

Interna 1 Hydrogen

\begin{tabular}{lll}
\hline $\mathrm{J}_{\mathrm{m}}^{* *}$ & $\mathrm{dJ} / \mathrm{da}$ & $\begin{array}{l}\text { Tensile* } \\
\text { Ductility }\end{array}$ \\
\hline
\end{tabular}

Nitronic 40

Nitronic 50

Nitronic $50 \quad$ Nitronic 40

Nitronic 40

$304 \mathrm{~L}$

$304 \mathrm{~L}$

$304 \mathrm{~L}$

A-286

A-286

* Orientation dependence not measured.

** Ranking is orientation dependent. 
Furthermore, compact tensile specimens such as the C-shaped specimens of this study are not susceptible to unstable plastic tearing, whereas tensile specimens can be driven to tearing instability by internal microcracks in the necked region.

There is agreement in ranking of HERF Type 304L and HERF Nitronic 40 stainless steels between tensile ductility and tearing resistance, $\mathrm{dJ} / \mathrm{da}$. In both cases, HERF Nitronic 40 stainless steel is less susceptible to hydrogen damage. In this comparison, both parameters are influenced by the deformation and crack growth processes that succeed the onset of crack growth at load maximum.

Static Loading. Static loading may lead to slow-crack growth in high-pressure hydrogen in some stainless steels, Figure $20.26,29-33$ The only alloys where crack growth was not seen had yield strengths below $800 \mathrm{MPa}$. The specimens were too thin to permit reaching a stress intensity high enough to cause crack growth. In all cases, the threshold stress intensities are substantially less than the fracture toughness. The scatter band for fracture toughness derives from valid J-integral tests made at 4.2 or $77 \mathrm{~K}$. $\mathrm{K}_{\mathrm{IC}}$ may be higher or lower at room temperature depending upon the steel. 34-35

Crack propagation has been observed in notched specimens of Type 304 stainless steel at stresses equal to $80 \%$ of the ultimate tensile strength. 29 These tests were in dry hydrogen at one atmosphere pressure at room temperature. A notched tensile specimen of Type $304 \mathrm{~L}$ stainless steel failed after 41 hours in air under a stress of $490 \mathrm{MPa}$, or 85 percent of the notch tensile strength. This specimen had been exposed to $\mathrm{D} / \mathrm{T}$ for 200 days at $69 \mathrm{MPa}$ and $380 \mathrm{~K}$. An unexposed control specimen survived 200 hours at $650 \mathrm{MPa}$ ( $85 \%$ of notch tensile strength) without failure. In another experiment with smooth specimens of Type $304 \mathrm{~L}$ stainless steel, no crack growth was observed after cathodic charging for stresses close to the ultimate tensile strength. ${ }^{30}$ As seen in Table 8 , a pre-existing crack did not progagate in Type 304L stainless steel tensile tube until the stress reached a very high level. Also, crack growth has not been observed in Type 310 stainless steel at $80 \%$ of the ultimate strength. 29 In A-286 stainless steel, hydrogen enhanced crack growth was observed at stresses above the yield strength, but tensile properties were unaffected by exposure to $69 \mathrm{MPa}$ hydrogen. 31 The threshold stress intensity for crack growth in $35 \mathrm{MPa}$ hydrogen was less than $113 \mathrm{MPa} \sqrt{\mathrm{m}}$ compared to greater than $154 \mathrm{MPa} \sqrt{\mathrm{m}}$ in helium.

Measurements of sustained-load cracking were made on a modified A-286 stainless steel $(\mathrm{JBK}-75)$ in hydrogen gas at 100 and $200 \mathrm{MPa}$ pressure. 32 Yield strengths varied from 690 to $930 \mathrm{MPa}$ with different thermomechanical treatments. Crack advance was intergranular 


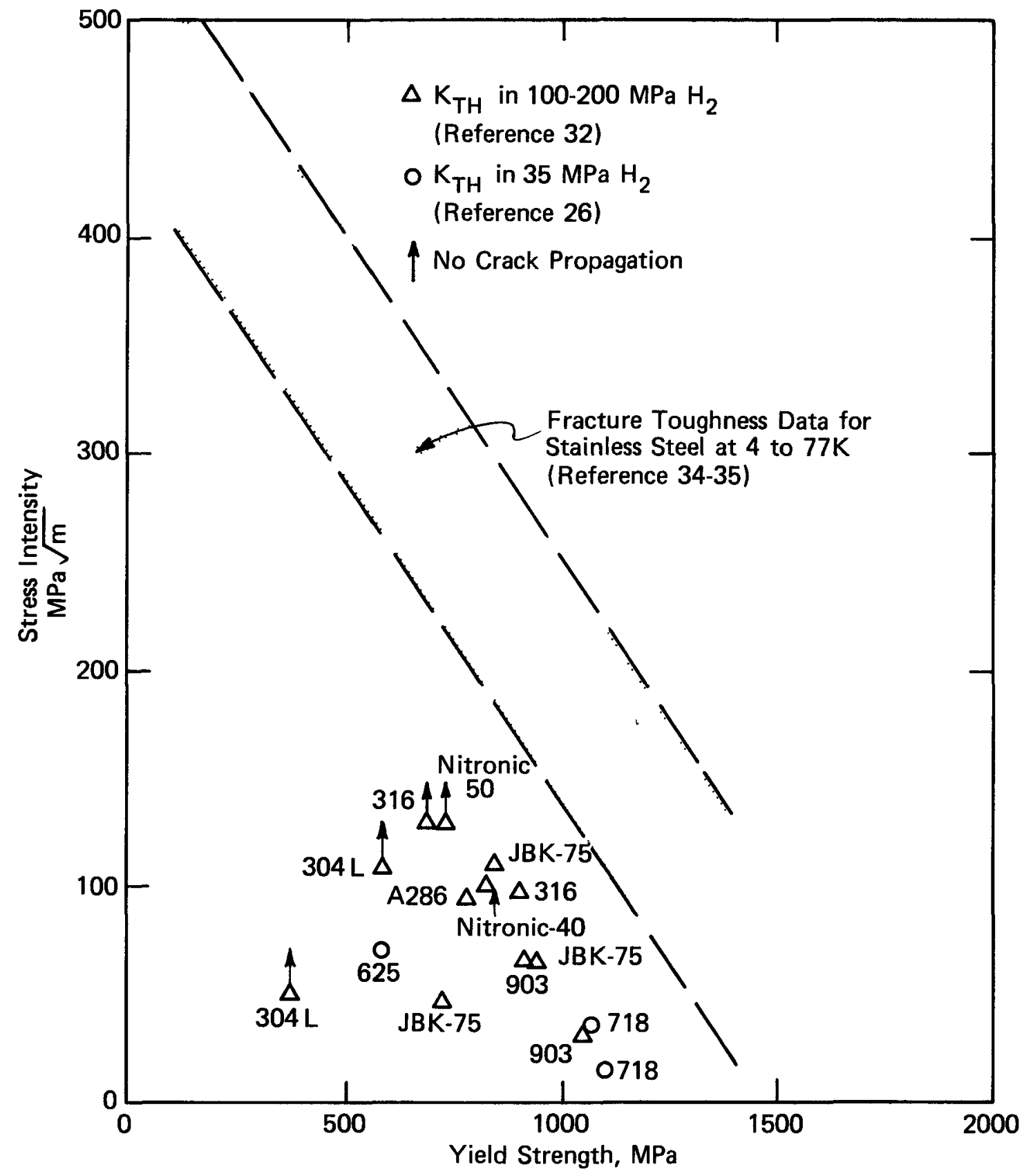

FIGURE 20. Hydrogen Effects on Crack Growth in Stainless Steels 


\section{TABLE 8}

\section{Stress Necessary for Slow-Crack Growth in Type 304L* Stainless Steel}

\begin{tabular}{|c|c|c|c|}
\hline $\begin{array}{l}\text { Net Section } \\
\text { Stress, MN } / \mathrm{m}^{2}\end{array}$ & $\frac{\text { Time, }}{\text { Incremental }}$ & $\begin{array}{l}\text { Hours } \\
\text { Accumulated }\end{array}$ & $\begin{array}{l}\text { Crack } \\
\text { Growth } \\
\end{array}$ \\
\hline 600 & 325 & 325 & No \\
\hline 641 & 72 & 397 & No \\
\hline 682 & 72 & 469 & No \\
\hline 724 & 72 & 541 & No \\
\hline 765 & 72 & 613 & No \\
\hline 786 & 1.4 (failed) & 614.4 & Yes \\
\hline
\end{tabular}

* Crack developed during room temperature tensile test in hydrogen environment; net section stress when tensile test was stopped was $772 \mathrm{MN} / \mathrm{m}^{2}$. Specimen then loaded in creep frame at indicated stresses without removal from the hydrogen environment. 
at threshold stress intensities of 110 to $44 \mathrm{MPa} \sqrt{\mathrm{m}}$. The presence of grain-boundary precipitates led to the lowest threshold stress intensities. Slow-crack growth was also seen in Nitronic ${ }^{\circledR} 40$, where the threshold stress intensity was around $100 \mathrm{MPa} \sqrt{\mathrm{m}}$. Sustained load crack growth was not observed in HERF Type 304L, HERF Type 316, or HERF Nitronic 50 stainless steels at either 100 or $200 \mathrm{MPa}$ hydrogen pressure. 32

Incone $1^{\circledR} 718$ is the only alloy for which hydrogen compatibility has been systematically evaluated by several test methods. ${ }^{26}$ Mechanical tests included notched- and smooth-bar tensile tests, lowand high-cycle fatigue, fracture mechanics, disc pressure tests, and stress rupture. Ductility of notched tensile specimens and fatigue life were more severely degraded than the other properties. Notched tensile and disc pressure tests were sensitive to hydrogen damage at pressures below about $6.9 \mathrm{MPa}$. These results and tests on other materials suggest that notched tensile and disc pressure tests are suitable for screening alloys for possible hydrogen service. However, selection of a test method for more detailed investigation depends not only on sensitivity of the method and severity of degradation but also on how well the test duplicates loading conditions and hydrogen pressures for the intended service application and possible material flaws.

Strain Rate. Hydrogen-assisted fracture in Type 304L stainless steel displays an inverse strain rate effect. This effect is common in all metals where hydrogen-assisted fracture is observed. The more usual strain rate effect, observed in lowtemperature brittleness of carbon steels for example, is for higher strain rates to increase brittleness. The inverse strain-rate effect in hydrogen-assisted fracture has been cited as evidence that hydrogen diffusion to high stress regions is necessary for embritt lement.

\section{FRACTOGRAPHY}

Detailed examination of fractured specimens has been carried out in recent years by scanning electron microscopy (SEM) which is the basis for the descriptions of fracture modes in this section.

\section{Fracture Modes}

Ductile fracture of stainless steels occurs ordinarily by a process of microvoid coalescence. Decohesion at the matrixinclusion interfaces or fracture of brittle inclusions creates microvoids. The material between the voids fails by localized flow or shear. This process originates throughout the individual grains with no preferred fracture path, leading finally to the common cup-cone or slant fracture. 
Hydrogen-assisted fracture of stainless steels is not associated with a unique fracture mode. On a macroscopic scale, fractures are mixed mode, partly flat, and partly slant or a modified cup-cone fracture. The microscopic fracture modes observed in hydrogen-assisted fracture of stainless steels are microvoid coalescence, cleavage, twin-boundary parting, intergranular separation, and interphase separation. In the following section, these fracture modes are described and related where possible to alloy composition, treatment, and external conditions, such as temperature and stress state.

\section{Microvoid Coalescence}

Most hydrogen-assisted fractures of stainless steels are, to some extent, ductile, with areas of dimpled fracture evident even when gross ductility is only 10 to $20 \%$, Figure 21 . With some alloys and test conditions, a change in dimple size is evident for the HAF. Dimple diameters were measured for several Type 304L stainless steel specimens, both with and without prior exposure to hydrogen. The average dimple size in HAF was always smaller than that for fracture of hydrogen-free specimens. Loss of tensile ductility has been correlated with change in dimple size for austenitic steels. The larger the change in dimple size, the greater the ductility loss. However, the results from tensile tests of Type $304 \mathrm{~L}$ steel at 250 and $270 \mathrm{~K}$ do not fall on the published curve, which was derived from room temperature tensile tests. 17

\section{Twin-Boundary Parting}

Twin-boundary parting, in Figure 22, was the characteristic mode of HAF in Type 304L stainless steel, Tenelon, and Nitronic 40. The incidence of this fracture mode was strongly dependent on temperature and composition. For example, twin-boundary parting was observed in Type 304L stainless steel but not in Type 316 stainless steel. The most clearly defined examples of twin-boundary parting occurred at test temperatures of 200 to $250 \mathrm{~K}$ in Type $304 \mathrm{~L}$ stainless steel, at 78 and $200 \mathrm{~K}$ in Tenelon and at $200 \mathrm{~K}$ in Nitronic 40 . Twin-boundary parting is observed in Tenelon at $78 \mathrm{~K}$ even when there is no hydrogen present.

Examination of numerous fractures has shown that twin-boundary parting is characterized by the following features:

- A single facet extends over one grain only.

- Facets usually have steps about $5 \mu \mathrm{m}$ in height.

- Traces of deformation bands in the underlying grain are visible. 

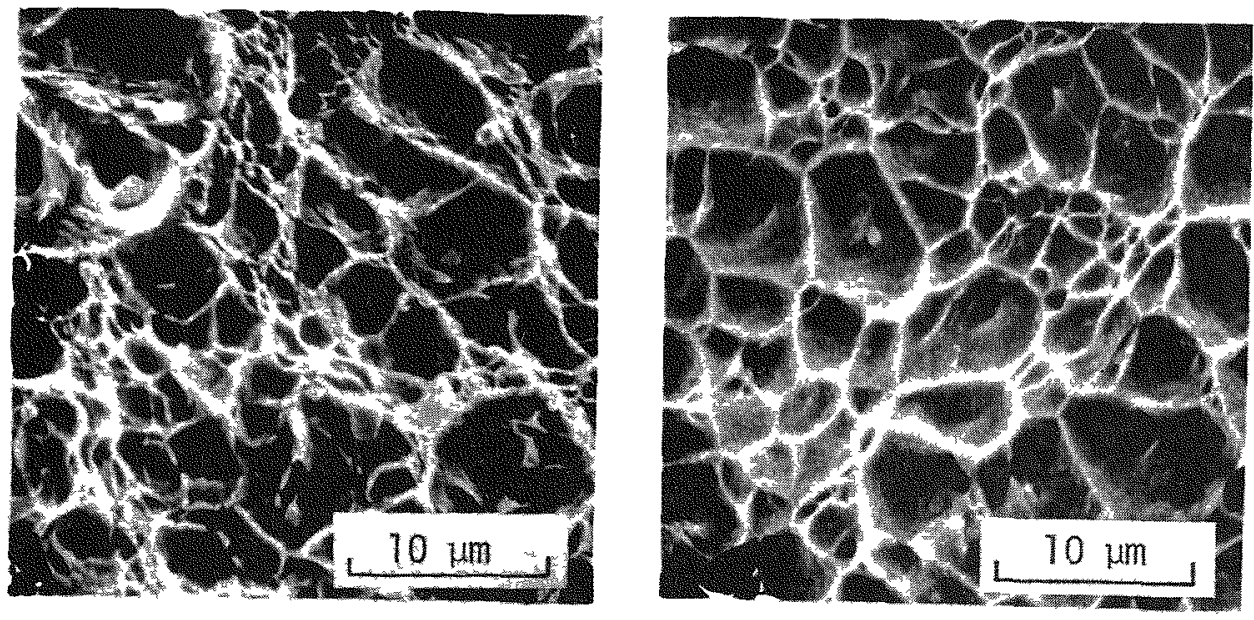

FIGURE 21. Dimpled Fracture of Type 304L Stainless steel
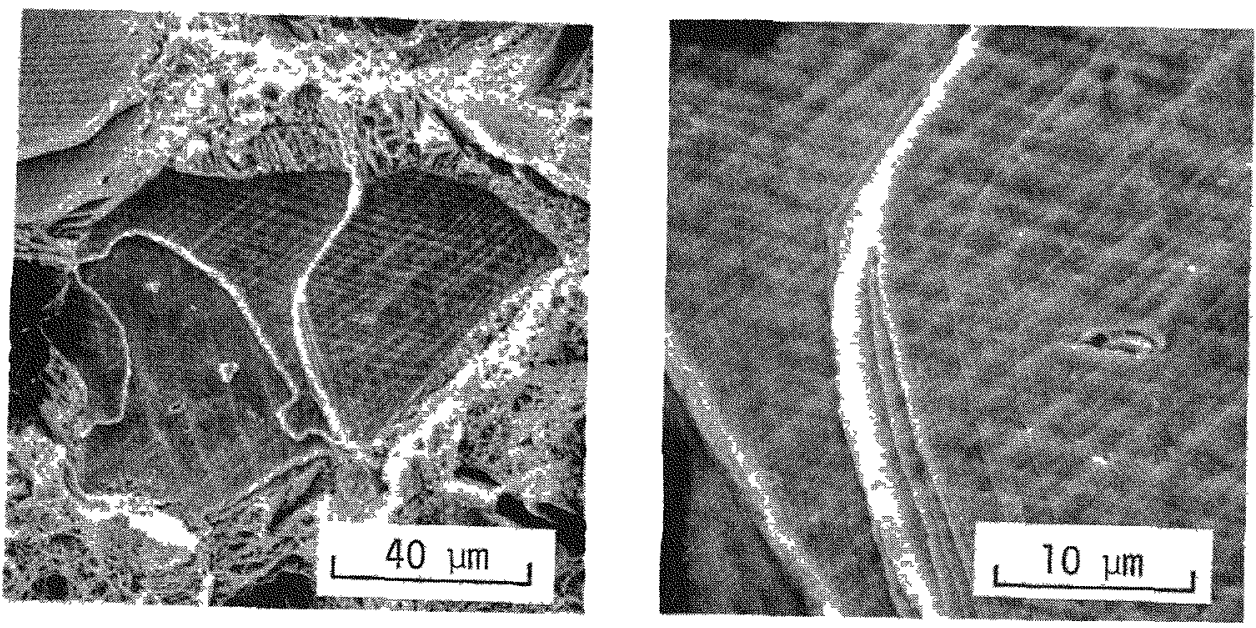

FIGURe 22. Twin-Boundary Parting in Type 304t stainless steel. High Energy Rate Forged. Tested $200 \mathrm{R}$. 
- Opposing halves of the fracture match and interlock.

- Facets are slightly curved because of lattice bending prior to separation along the twin boundary.

- River patterns characteristic of cleavage are never seen.

On a longitudinal section of a tensile specimen, twin-boundary parting shows as microcracks throughout the deformed portion of the specimen. Microcracks form on boundaries oriented roughly transverse to the tensile axis, Figure 23. The frequency of occurrence of microcracks correlates with the temperature of maximum hydrogen damage, Table 9, just as the number of facets on the fracture face varies with temperature, Figure 24. Multiple nucleation of microcracks is seen also, Figure 25, and suggests that twin-boundary parting proceeds by the linking of many cracks which nucleate at intersections of deformation bands with the twin-boundary. Acoustic emission confirms the notion that crack growth is by many small steps rather than one abrupt energy release.

\section{Transgranular Cleavage}

Transgranular cleavage was a form of HAF observed in ferritic and martensitic stainless steels. For example, the fracture mode of 17-4 $\mathrm{PH}$ was predominatly transgranular cleavage as seen in Figure 26. This fracture mode can yield facets similar to those of twin-boundary parting, but the facets are readily distinguished at high magnification by the occurrence of river patterns.

\section{Intergranular Separation}

Intergranular separation was characteristic of HAF of alloys containing more than about 30 or $35 \%$ nickel but was not limited to these alloys. Commercial grades of nickel displayed the most clearly delineated intergranular separation, Figure 27. However, specific thermal treatment could evoke intergranular separation in most alloys. In the case of nickel, intergranular separation was increased by prolonged heating at $770 \mathrm{~K}$.

Intergranular separation has been observed in C-shaped specimens of HERF Nitronic 40 and A-286 stainless steel also, Figure 28 . Precharging with hydrogen is needed to evoke the intergranular separation. The presence of intergranular fracture in C-shaped specimens and its absence in smooth bar tensile specimens suggests that stress state affects fracture mode in stainless steels. There is a bending moment on the C-shaped specimens which is absent in a tensile test. 

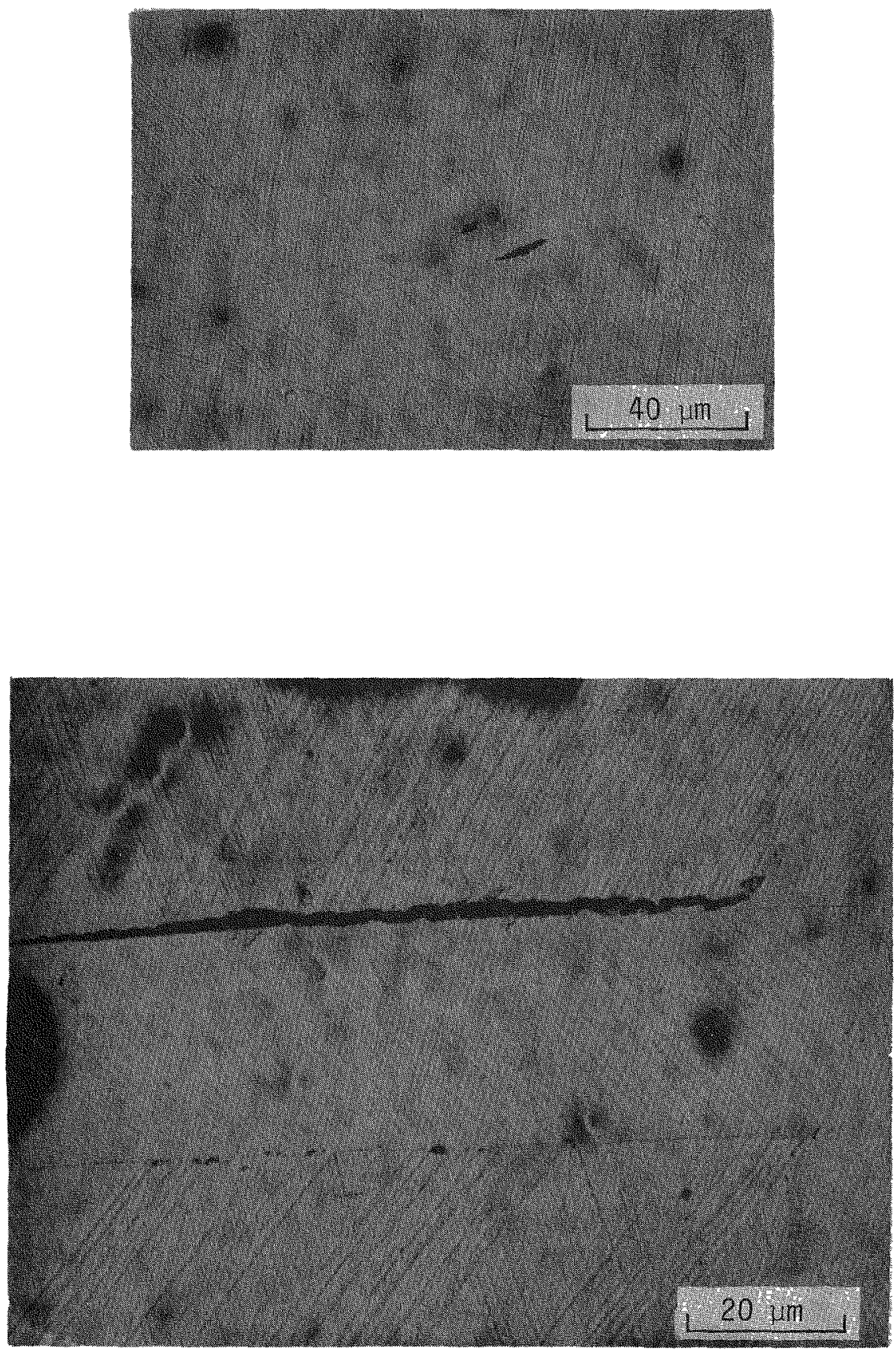

FIGURE 23. Microcracks Along Boundaries of Annealing Twins 


\section{TABLE 9}

Occurrence of Microcracks in Hydrogen-Saturated Austenitic stainless steel.

\begin{tabular}{|c|c|c|c|}
\hline $\begin{array}{l}\text { Test } \\
\text { Temp } \mathrm{K}\end{array}$ & $\frac{\text { Microcrack }}{\text { Type } 304 \mathrm{~L}}$ & $\frac{\text { Frequency }}{\text { Tenelon }}$ & $\frac{\text { (Number Cracks } / \mathrm{cm}^{2} \text { ) }}{\text { Nitronic }}$ \\
\hline 380 & 0 & - & 0 \\
\hline 348 & - & 0 & - \\
\hline 298 & - & - & 60 \\
\hline 273 & 90 & 900 & - \\
\hline 248 & 150 & - & 230 \\
\hline 198 & 1800 & 1100 & 1400 \\
\hline 78 & 0 & $(4) *$ & 0 \\
\hline
\end{tabular}

* Number of microcracks observed in close proximity to the fracture surface.

Al1 specimens saturated with deuterium at $69 \mathrm{MPa}$ pressure at $570-620 \mathrm{~K}$. 


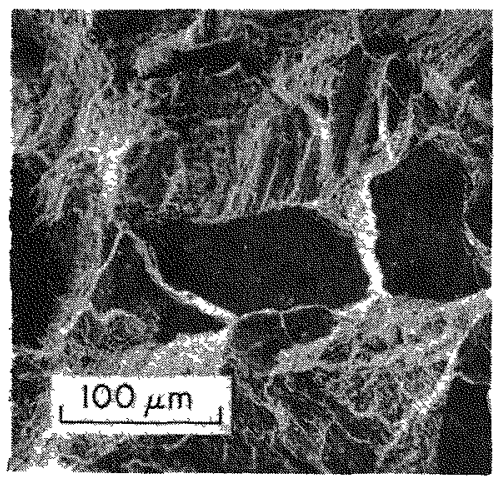

$198 K$

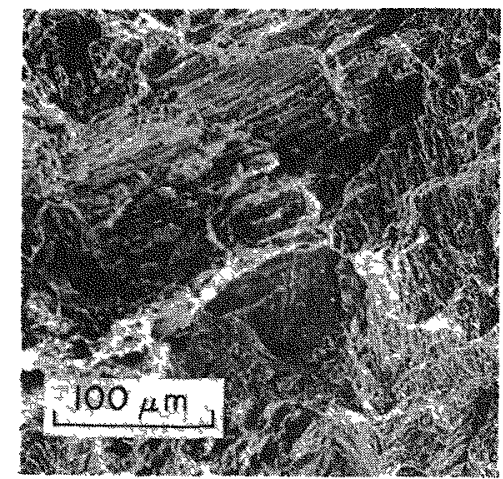

$273 K$

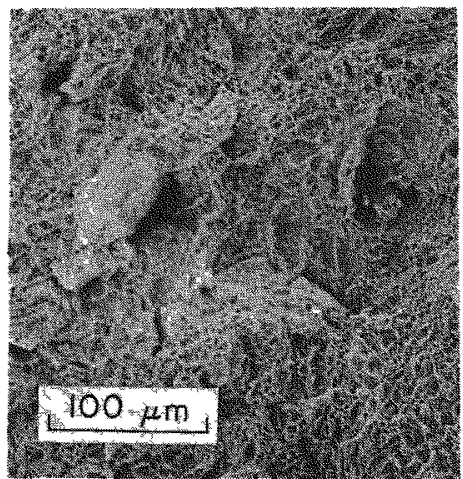

$298 \mathrm{~K}$

FIGURE 24. Variation of Iacet Appearance with Test Temperature in Type 304L Stainless steel 


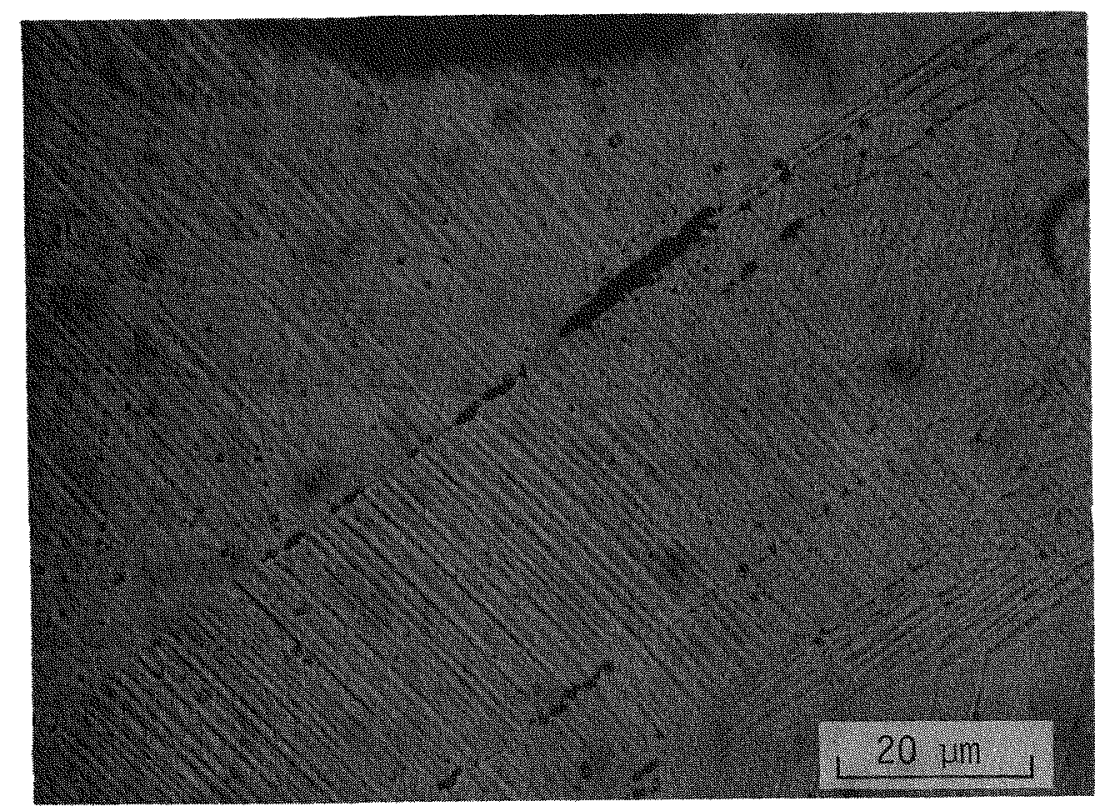

a) On Twin Boundary

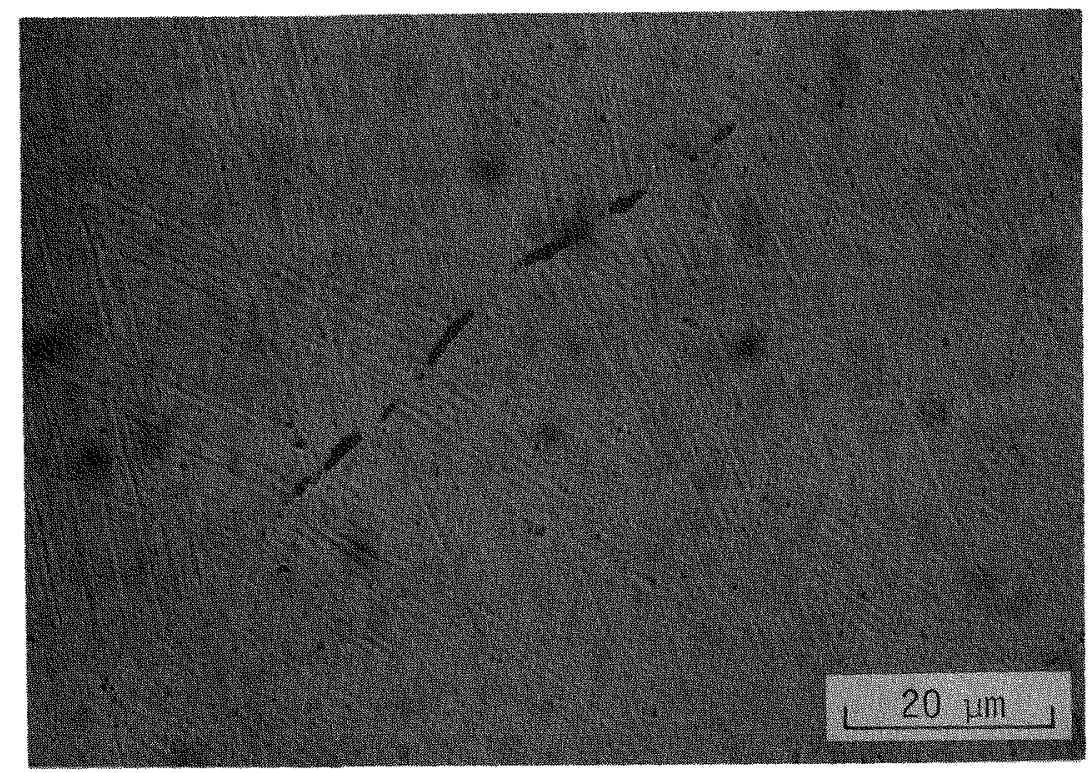

b) On Grain Boundary

FIGURE 25. Multiple Crack Nucleation Along Boundaries 


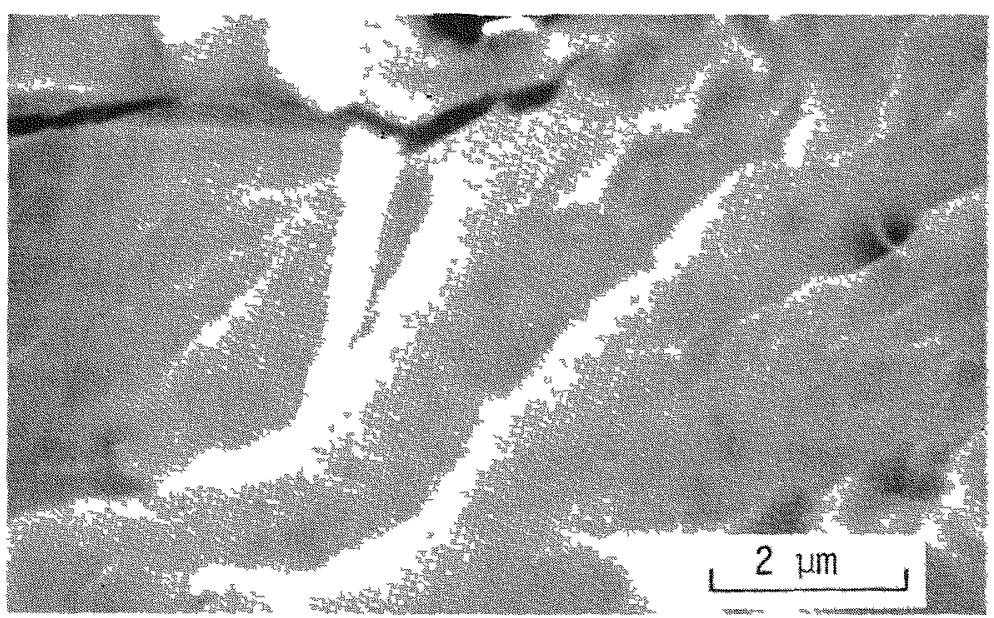

FIGURE 26. Transeranular Cleavage in 17- Pa Precipitation-Hardenable stainblea steel
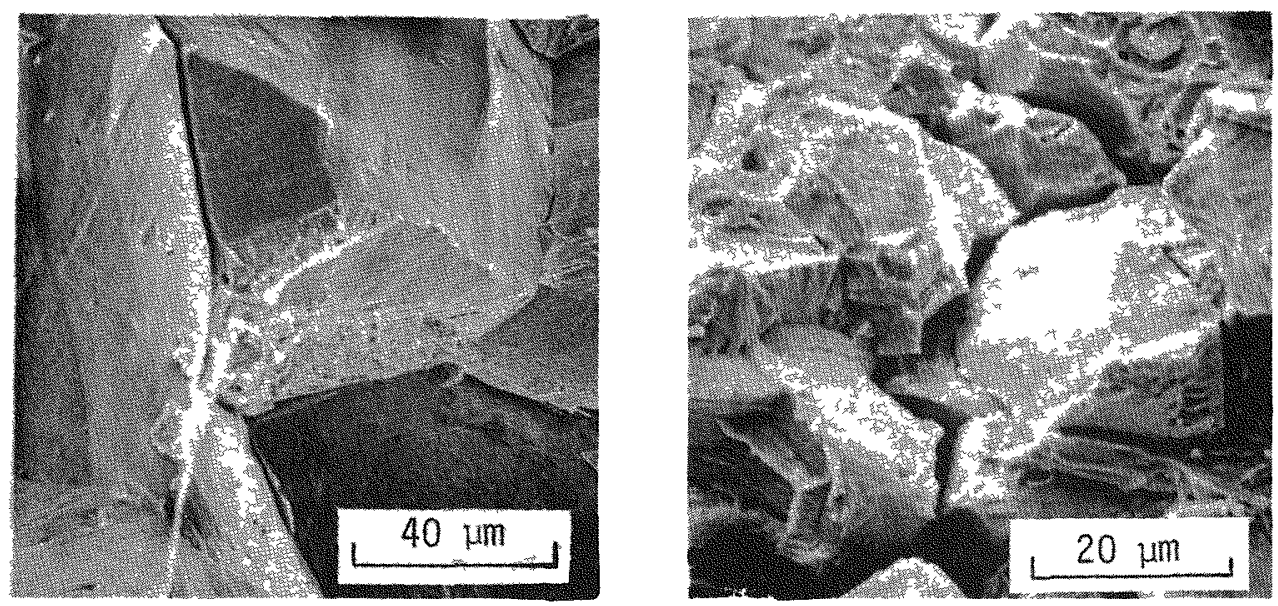

IGURE 27. Intergranular Separate in Nickel and Inconel 718 


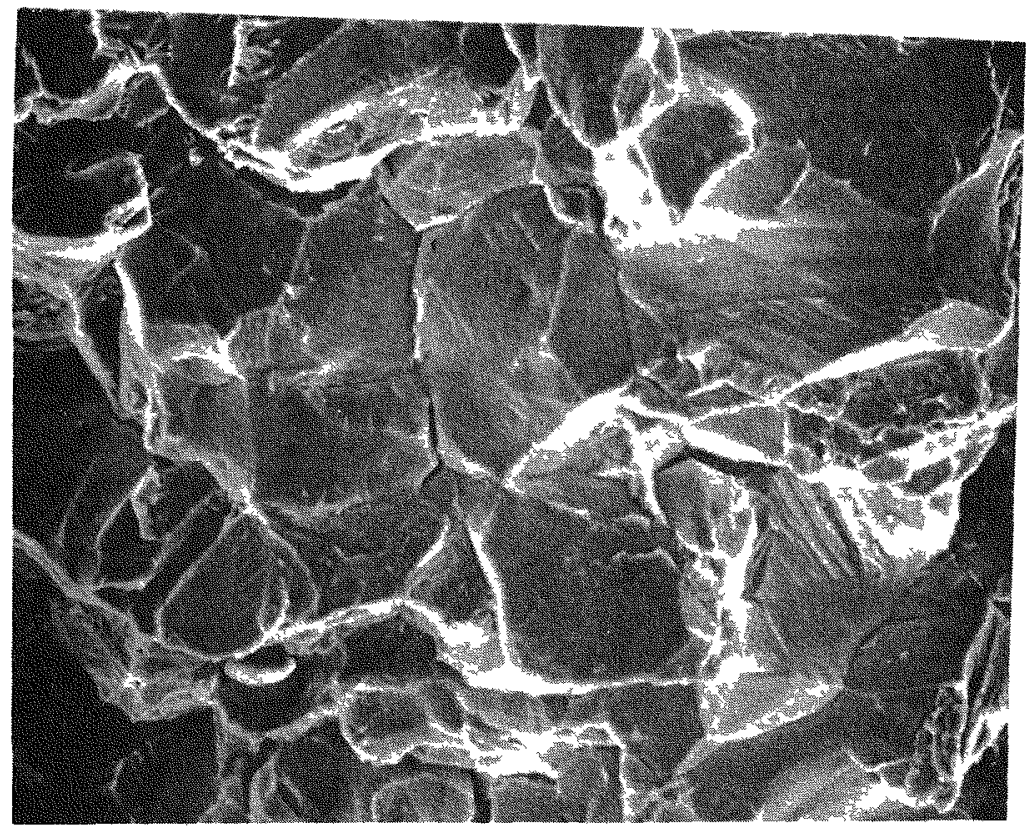

PIGURe 28. HER Itronic 40, Orientation 1. Integranular Fracture in Hydrogen. 
Intergranular fracture paths were observed after tensile tests in a hydrogen environment in sensitized specimens of Type 304L, 304,23 and Nitronic ${ }^{\circledR} 40$ stainless steel but not Type 309S.24 Moreover, the presence of an intergranular fracture does not appear to be contingent upon apparent continuity of the carbide phase. Continuous carbides and intergranular fracture were observed in Type 304 and Nitronic ${ }^{\circledR} 40$ stainless steels, but no intergranular fracture occurred in Type 3095 stainless steel in spite of formation of continuous grain-boundary carbides. Furthermore, extensive intergranular fracture took place during failure of Type 304 stainless steel where carbide precipitation was discontinuous. In the case of Type $304 \mathrm{~L}$ steel, a distinct difference in fracture appearance was noted which depends upon the frequency of occurrence of grain boundary carbides. An intergranular fracture path occurred only when the carbide network was nearly continuous on at least some grain faces. Otherwise, the fracture was mixed void coalescence and partially brittle but not intergranular.

Although continuity of carbide precipitation on grain faces appears to be the dominant factor controlling the fracture path, one or more other factors must be present to explain the above observations. Phosphorus segregation to the grain boundaries and possible formation of an ( $\mathrm{Fe}, \mathrm{Cr}$ ) $\mathrm{Ni}-\mathrm{P}$ surface phase have been demonstrated as the cause of temper embrittlement of Type 304 stainless stee1.36 Intergranular fracture at $150 \mathrm{~K}$ was observed on notched tensile specimens annealed 2 hours at $920 \mathrm{~K}$. Surface segregation of phosphorus is also found by Auger electron spectroscopy after vacuum annealing at 820 to $1020 \mathrm{~K}$. These studies suggest that phosphorus may be a factor in causing intergranular fracture of sensitized austenitic steels, but experimental data are inadequate to confirm the possibility.

\section{Interphase Separation}

HAF in austenitic steels often propagates along interphase interfaces such as austenite-martensite or austenite-ferrite interfaces. Welds in austenitic steels, such as Type $304 \mathrm{~L}$, contain several percent of $\delta$-ferrite which forms during solidification of the weld bead. The presence of the $\delta$-ferrite helps prevent hot shortness or weld cracking but is a preferred path for crack propagation in the presence of hydrogen, Figure 29a.

Some stainless steels are unstable when deformed and transform to $\varepsilon$-martensite (a HCP lattice) or $\alpha$-martensite (a BCC lattice). Again the interfaces between the austenite and either form of strain-induced martensite are likely crack paths. Fracture surfaces in these cases have a crystallographic appearance with many intersecting planar facets, Figure 29b. In Type 304L steel, this fracture path is common around room temperature in specimens that have been precharged with hydrogen prior to deformation. 


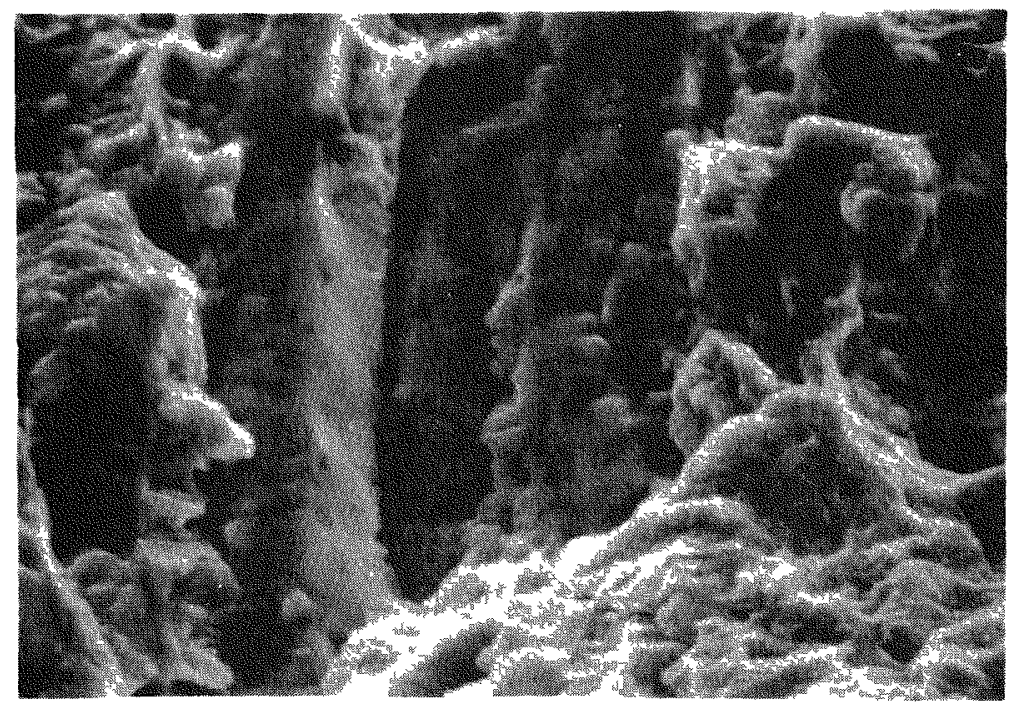

a) Austenite-Ferrite Interface in Type 304L Meld Metal

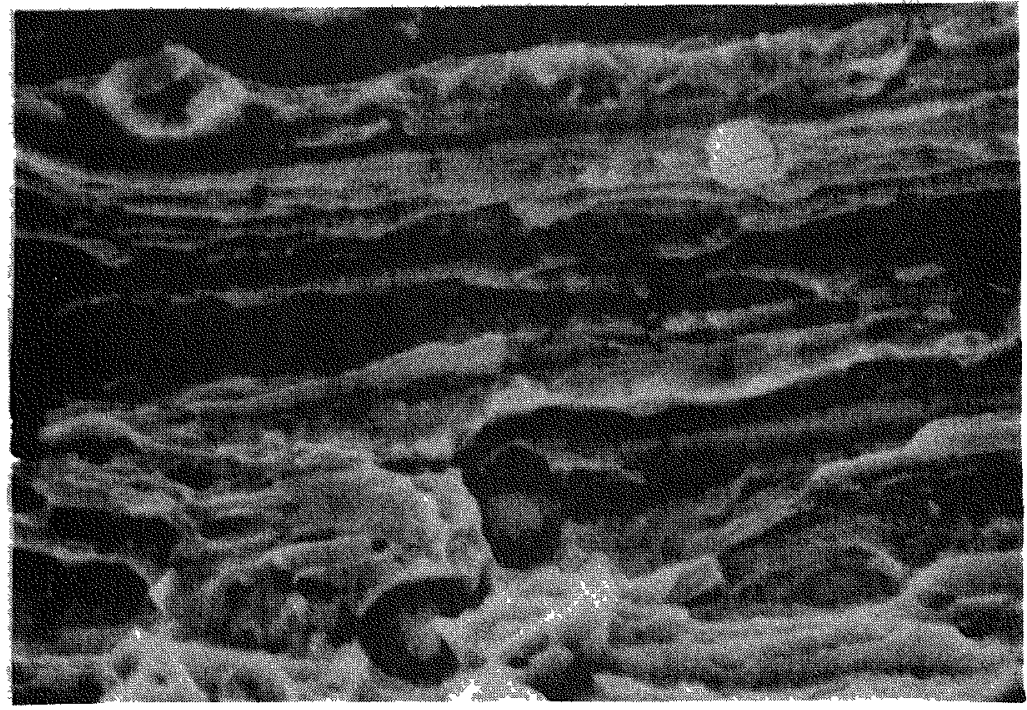

b) Austenite-Martensite Interface in Type 304L FIGURE 29. Fracture Along Interphase Interfaces in Austenitic steels 
Fracture along austenite-martensite interfaces in Type $304 \mathrm{~L}$ stainless steel appears more common around room temperature than at lower temperatures. Twin-boundary parting dominates the fracture at $200-250 \mathrm{~K}$ and microvoid coalescence is seen at $78 \mathrm{~K}$. Clearly, the operative fracture path is very sensitive to test temperature.

\section{Correlation of Fracture Mode with Composition}

Fracture modes for HAF of iron-chromium-nickel alloys vary with percent of nickel in the alloy, Figure 30. Alloys such as $17-4 \mathrm{PH}$ with on $1 \mathrm{y} 4 \%$ nickel fail by transgranular cleavage. As the nickel content increases, the steels become austenitic (metastable), and fracture by twin-boundary parting appears at around $10 \%$ nickel. A region of dimpled fracture occurs from 15 to 25 or $30 \%$ nickel, which is gradually supplanted by intergranular separation as the nickel content increases. However, there were only a few alloys in which on $1 y$ a single fracture mode was observed. In most instances, two or more fracture modes occurred, one of them being microvoid coalescence.

Alloy composition is a controlling factor in HAF in two ways: 1) the base alloy determines slip character and phase stability during straining, and 2) impurity and trace elements may be strongly segregated and induce intergranular separation either alone or in combination with hydrogen. Planar slip is associated with lownickel austenites and leads to high-stress concentrations at slip barriers, such as inclusion, twin, and grain boundaries. Sites of high-stress concentration may act as microcrack nucleation centers, especially in the presence of hydrogen, which may lower the cohesive strength. Austenite stability under strain is also correlated with nickel content. Formation of deformation twins, $\varepsilon$-phase, and $\alpha$-martensite occurs more readily with lower nickel concentrations. Both slip planarity and phase stability are related to stackingfault energy. Greater resistance to hydrogen damage in austenitic steels has been correlated with higher stacking-fault energy. The transition from twin-boundary parting to dimpled fracture at around 12 to $14 \%$ nickel correlated with an increase in stacking-fault energy to over 30 or $40 \mathrm{~mJ} / \mathrm{m}^{2}$.

Intergranular separation in all of the stainless steels may be attributable to impurity segregation. Sulfur in high-nickel alloys and phosphorus in austentic steels are known to cause intergranular failures. These impurities are not the only causes of intergranular fracture, however. Sensitization of austenitic steels leads to carbide pecipitation and grain-boundary regions depleted in chromium and causes intergranular fracture in Type $304 \mathrm{~L}$ stainless steels. These examples illustrate the sensitivity of HAF to relatively small changes in either base alloy composition or impurity content. Control of melting, casting, and mechanical and thermal 


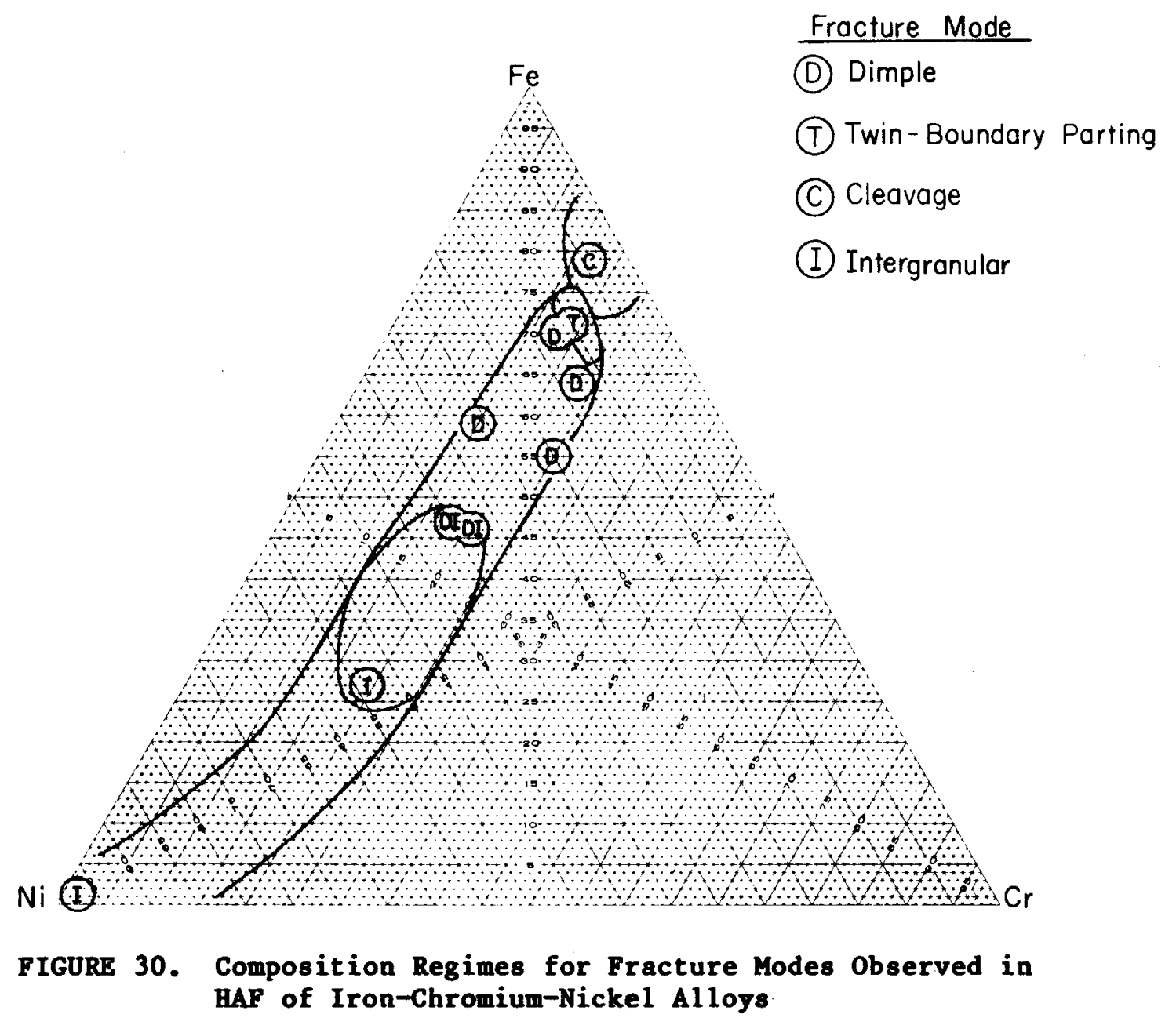


processing becomes more important for hydrogen service than for service in air. Small changes in local composition due to variations in process control can develop conditions for HAF in an otherwise resistant alloy.

\section{HELIUM EMBRITTLEMENT}

The hydrogen isotopes are alike in their short-term chemical effect on the properties of stainless steels. Long-term effects differ, however, because tritium decays with a 12.35 year half-1ife to helium- 3 by emission of a low energy ( $5.7 \mathrm{keV}$ average) beta particle, whereas protium and deuterium are stable. Helium is known to embrittle many metals but normally elevated temperatures are required for an observable effect. 37 Exposure of metals to tritium causes "hydrogen damage," which occurs immediately and slowly diminishes as tritium decays, as well as helium embrittlement, which becomes significant after tritium decay has generated sufficient helium. Helium damage is additive to the damage caused by the hydrogen isotopes and has been identified in Armco (Armco, Inc.) iron - and niobium as well as in several grades of stainless austenitic steel.

The earliest studies of the effects of helium-3 on the mechanical properties of stainless steel were reported in $1975.37,38$ Foil specimens $(0.025 \mathrm{~cm}$ thick) were exposed to $47.5 \mathrm{MPa}$ tritium at $343 \mathrm{~K}$ for 17 months; helium build-in was estimated at 6.2 mol $\mathrm{He}(\mathrm{STP}) / \mathrm{m}^{3}$. Subsequent tests at room temperature indicated that the exposure increased the yield strength, but had little effect on the ductility of the Type 309S steel specimens, although the ductility of Type $304 \mathrm{~L}$ steel was lowered. Microvoid coalescence was the primary fracture mode. Helium bubbles about $5 \mathrm{~nm}$ in size were found in both steels in grains and on grain boundaries.

Transmission electron microscopy of samples charged with tritium showed gas bubbles formed on dislocation networks (Figure 31), and grain boundaries following a 0.5 hour anneal at $973 \mathrm{~K}$. Further a tensile test at $973 \mathrm{~K}$ showed that the helium, which had built in, during the charging, agglomerated during the test, which caused the fracture mode to change from ductile rupture to intergranular separation and reduced the strength and ductility of both Type 309s and 304L stainless steels.

Helium damage at ambient temperature was convincingly demonstrated in smooth-bar tensile specimens $(2.5-\mathrm{cm}$ gage length and $0.356-\mathrm{cm}$ diameter) of HERF Nitronic 40 stainless steel gas-phase charged with tritium at $64 \mathrm{MPa}$ at $470 \mathrm{~K}$ for 1450 hours and aged 


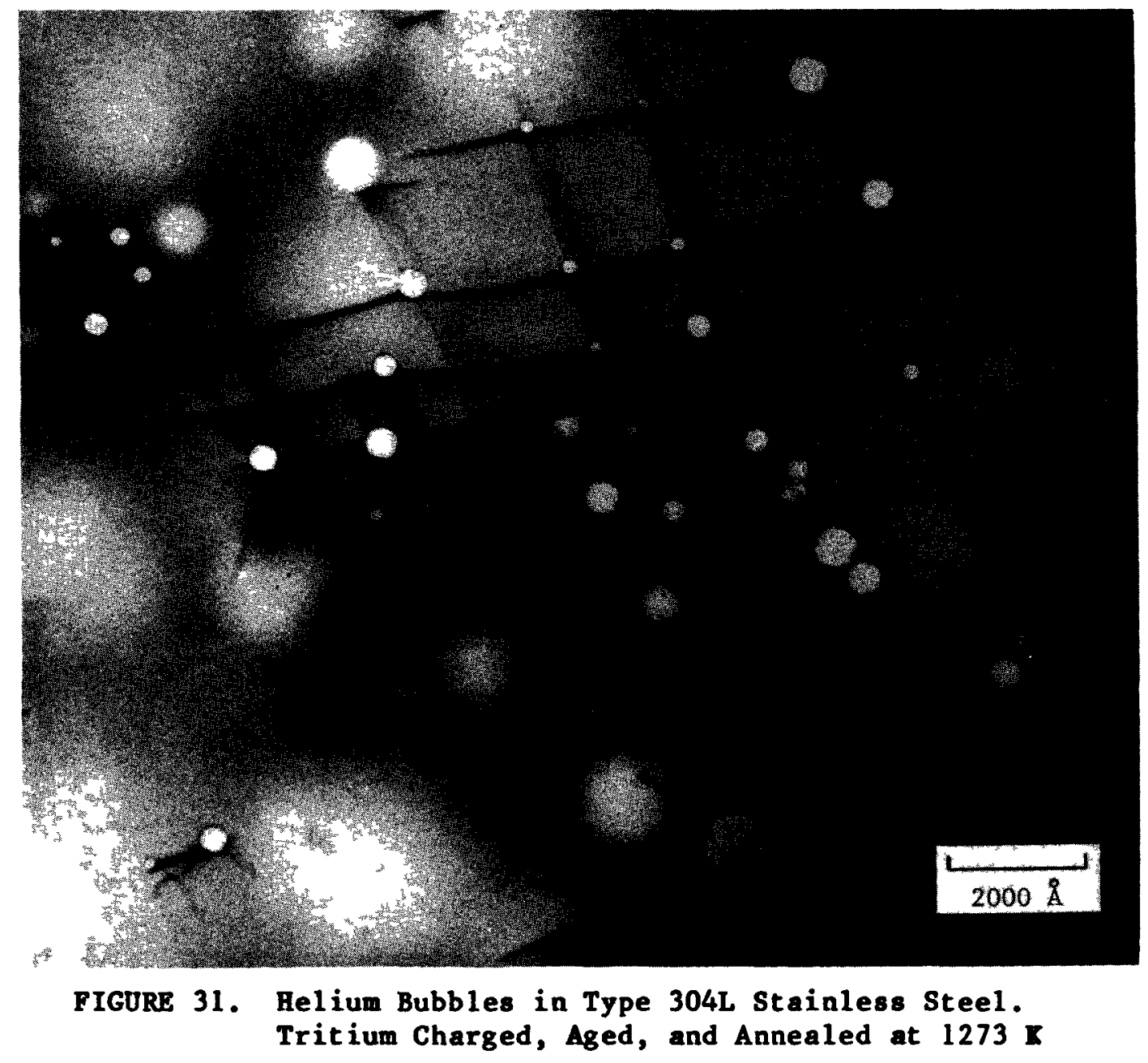


5.5 years at $250 \mathrm{~K}$. Comparison specimens of Type 304L stainless steel were only affected a smal1 amount by the same treatement. 39 Tritium and helium distributions in the specimens are nonuniform for these charging conditions. Some of the charged specimens were tested at $298 \mathrm{~K}$ immediately after charging, and others were stored from five to seven years at $250 \mathrm{~K}$ before testing, Tables 10 and 11 . After 5.5 years' storage, helium concentrations were about $100 \mathrm{~mol}$ $\mathrm{He}$ (STP) $/ \mathrm{m}^{3}$ at the surface of the Type $304 \mathrm{~L}$ steel specimen and about $174 \mathrm{~mol} \mathrm{He}(\mathrm{STP}) / \mathrm{m}^{3}$ in the Nitronic 40 . Average concentrations over the specimen cross section were 31 and $52 \mathrm{~mol} \mathrm{He}(\mathrm{STP}) / \mathrm{m}^{3}$.

These test results show:

1) Hydrogen and tritium reduce ductility of both Type 304L and Nitronic 40 stainless steel (Tables 10 and 11 ).

2) There was only a small change in the mechanical properties and no change of fracture mode in Type $304 \mathrm{~L}$ stainless steel with $100 \mathrm{~mol} \mathrm{He}(\mathrm{STP}) / \mathrm{m}^{3}$.

3) A drastic reduction in ductility and a change in fracture mode from microvoid coalescence to intergranular separation occurred in Nitronic 40 stainless steel (Table 11) with 174 mol $\mathrm{He}(\mathrm{STP}) / \mathrm{m}^{3}$.

There was a high density of small defects in the tritiumcharged and aged Nitronic ${ }^{\circledR} 40$ stainless steel, Figure 32 . Contrast analysis of the strain fields produced by these defects indicated that they were helium bubbles approximately $5 \mathrm{~nm}$ in size. The size and density of bubbles $\left(2 \times 10^{16}\right.$ bubbles $\left./ \mathrm{cm}^{3}\right)$ was consistent with the estimated helium content of the specimen. Measurements of the images produced by these defects indicate a misfit strain of about 0.017. Rather than being located at grain boundaries, the bubbles were dispersed throughout the matrix. A few bubbles were found in the Type $304 \mathrm{~L}$ stainless steel specimens, in keeping with the lower helium content. Helium is known to cause intergranular fracture by the formation of intergranular helium bubbles at high temperatures $\left(\mathrm{T} / \mathrm{T}_{\mathrm{m}}=0.5\right)$, where helium migration to internal boundaries can occur. 37 Data for Types $304 \mathrm{~L}$ and $309 \mathrm{~S}$ stainless steel and Armco (Armco, Inc.) 40 iron charged with tritium have shown helium embrittlement with only $0.2 \mathrm{~mol} \mathrm{He}(\mathrm{STP}) / \mathrm{m}^{3}$ can occur after a high-temperature anneal or testing at a high temperature.

HERF Nitronic 50 and welds in Type 304L stainless steel have shown ductility iosses associated with helium-3.41 Calculated helium concentration profiles in these specimens were similar to those in the HERF Nitronic 40 and HERF Type 304L stainless steels but the surface concentration of tritium was higher. All fractures in the HERF Nitronic 50 and welds of Type 304L stainless steels were ductile. 
TABLE 10

Mechanical Properties of HERF Type 304L Stainless Steel

\begin{tabular}{|c|c|c|c|c|}
\hline $\begin{array}{l}\text { Exposure } \\
\text { Conditions }\end{array}$ & $\frac{\text { Streng }}{\text { Yield }}$ & $\frac{h, M P a}{\text { U1timate }}$ & $\begin{array}{l}\text { Total } \\
\text { E1ongation, } \\
\%\end{array}$ & $\begin{array}{l}\text { Plastic } \\
\text { Strain to } \\
\text { Fracture } \\
\end{array}$ \\
\hline None & 630 & 790 & 32 & 1.83 \\
\hline $\begin{array}{l}69 \mathrm{MPa} \mathrm{H}_{2} \text { at } 480 \mathrm{~K} \text {, } \\
55 \text { days }\end{array}$ & 600 & 840 & 35 & 0.87 \\
\hline $\begin{array}{l}47 \mathrm{MPa} \mathrm{T} \mathrm{T}_{2} \text { at } 480 \mathrm{~K} \text {, } \\
17 \text { months and aged } \\
5.5 \text { years at } 250 \mathrm{~K}\end{array}$ & 620 & 745 & 33 & 0.73 \\
\hline
\end{tabular}

TABLE 11

Mechanical Properties of HRRF Nitronic 40 Stainless steel

\begin{tabular}{|c|c|c|c|c|}
\hline $\begin{array}{l}\text { Exposure } \\
\text { Conditions } \\
\end{array}$ & $\begin{array}{l}\text { Streng } \\
\text { Yield }\end{array}$ & $\frac{\mathrm{h}, \mathrm{MPa}}{\text { U1timate }}$ & $\begin{array}{l}\text { Total } \\
\text { Elogation, \% }\end{array}$ & $\begin{array}{l}\text { Plastic } \\
\text { Strain to } \\
\text { Fracture } \\
\end{array}$ \\
\hline None & 800 & 930 & 29 & 1.20 \\
\hline $\begin{array}{l}30 \mathrm{MPa} \mathrm{H}_{2} \text { at } 480 \mathrm{~K}, \\
56 \text { days and aged } \\
7 \text { years at } 250 \mathrm{~K}\end{array}$ & 845 & 990 & 28 & 0.76 \\
\hline $\begin{array}{l}65 \mathrm{MPa} \mathrm{T}_{2} \text { at } 480 \mathrm{~K} \text {, } \\
60 \text { days }\end{array}$ & 830 & 940 & 32 & 0.73 \\
\hline $\begin{array}{l}47 \mathrm{MPa} \mathrm{T} \mathrm{T}_{2} \text { at } 344 \mathrm{~K} \text {, } \\
17 \text { months and aged } \\
5.5 \text { years at } 250 \mathrm{~K}\end{array}$ & 870 & 925 & 6 & 0.10 \\
\hline
\end{tabular}


a) Hydrogen charged $69 \mathrm{MPa}$ at $470 \mathrm{~K}$ and aged 5.5 years

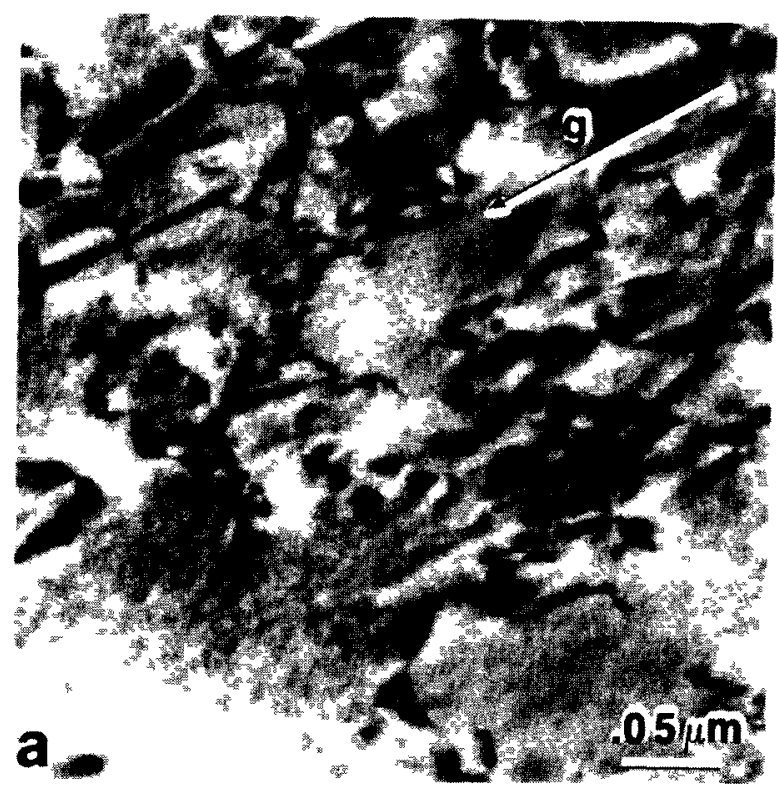

b) Tritium charged $47.5 \mathrm{MPa}$ at $345 \mathrm{~K}$ and aged 5.5 years

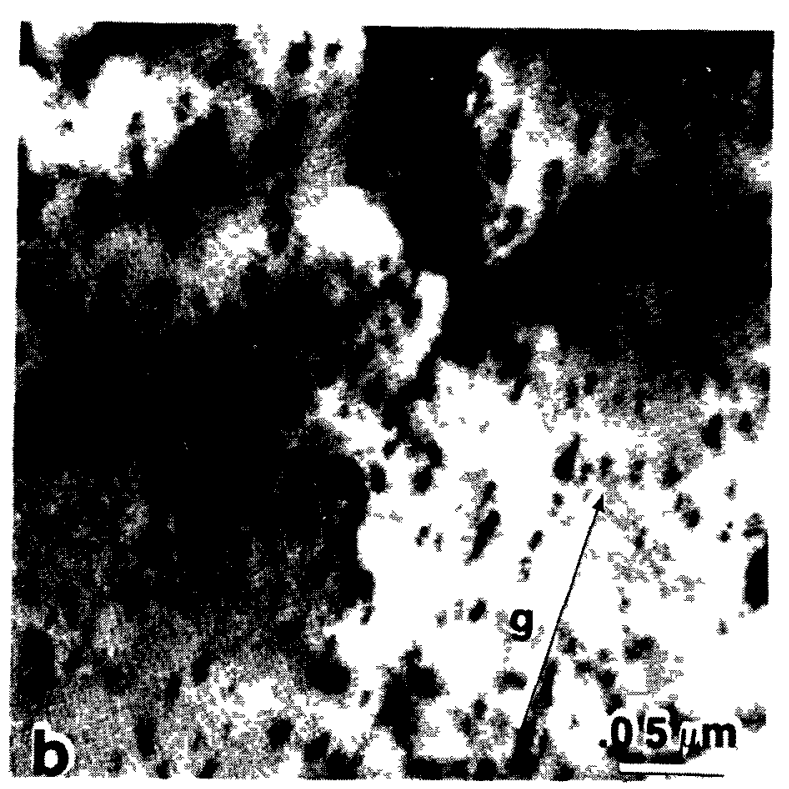

FIGURE 32. Microstructures in HLRF Nitronic 40 
A new investigation of helium effects was begun and is still in progress. 46 Notched C-shape specimens $3.8 \mathrm{~mm}$ thick and $25 \mathrm{~mm}$ outer radius were machined from five stainless steels: Type 304L, Type 316 , Nitronic $40, A-286$, and a modified A-286. The modified A-286 was in the annealed condition, all others were HERF. Specimens were not fatigue precracked. The specimens were exposed to tritium at $61 \mathrm{MPa}$ pressure at $422 \mathrm{~K}$ for six months.

Calculated tritium concentrations in Type 304L stainless steel were $270 \mathrm{~mol} \mathrm{~T} \mathrm{~T}_{2}(\mathrm{STP}) / \mathrm{m}^{3}$ at the surface and $60 \mathrm{~mol} \mathrm{~T}_{2}(\mathrm{STP}) / \mathrm{m}^{3}$ at the center based on the hydrogen solubility equation of Louthan and Derrick. 43 Tritium and helium contents average over the cross section were $167 \mathrm{~mol} \mathrm{~T}_{2}(\mathrm{STP}) / \mathrm{m}^{3}$ and $10 \mathrm{~mol} \mathrm{He}(\mathrm{STP}) / \mathrm{m}^{3}$. Following the 15-month ageing, average tritium and helium contents were 160 mol $\mathrm{T}_{2}$ (STP) $/ \mathrm{m}^{3}$ and $24 \mathrm{~mol} \mathrm{He}(\mathrm{STP}) / \mathrm{m}^{3}$. Actual concentrations in Nitronic 40 are probably higher since measurements of hydrogen solubility at $470 \mathrm{~K}$ have shown that hydrogen solubility is $70 \%$ higher than in Type 304L stee1.44

Tensile tests were run immediately after exposure and following 15 months' storage at $273 \mathrm{~K}$. Control specimens were exposed to air at $422 \mathrm{~K}$ for six months and stored at low temperature. Tensile tests were made in air at room temperature and the load-deflection curves were analyzed by the J-integral technique. $45 \mathrm{~J}$-integral at maximum load ( $\mathrm{Jm}$ ) and deflection at maximum load are given in Table 12 for the several test conditions.

The data demonstrate that helium has degraded the mechanical properties of, all five steels. Immediately after the six-month exposure, the difference in $\mathrm{Jm}$ between the control and charged specimens was due mostly to the tritium with only a small helium effect. After 15 months' storage at $273 \mathrm{~K}$, the difference between charged and control specimens was due to the additional helium generated during storage. HERF Type 316 and HERF Type 304L stainless steels were affected the least by the helium, and HERF Nitronic 40 and annealed A-286 (modified) were affected the most. The occurrence of a large helium effect in Nitronic 40 was not surprising, as a comparable result was observed earlier. 40 The difference in response to the presence of helium shown by HERF A-286 and annealed A-286 (modified) appears to be associated with microstructural differences arising from prior thermal or thermo-mechanical treatments. Composition differences between the two varieties of A-286 are small and probably contributed 1 ittle to the relative helium effect.

Sustained load tests were initiated after 22 months storage on all steels except modified A-286. Loads corresponded to 80 percent of the fracture load that was measured after 15 month's storage. Rapid crack growth occurred in Nitronic 40 and A-286 stainless steels but has not yet been detected in Type 316 or Type 304L after five months under load. The latter tests are continuing. 
TABLE 12

Tritium and Helium Effects on Fracture Toughness of Stainless Steel

\begin{tabular}{|c|c|c|c|}
\hline Alloy & History* & $\begin{array}{l}\text { Deflection at } \\
\text { Max. Load, mm }\end{array}$ & $\begin{array}{l}\text { Fractur } \\
\text { Toughne } \\
\text { Jm, kJ/ }\end{array}$ \\
\hline $304 \mathrm{~L}$ & $\mathrm{C}$ & 3.71 & 1280 \\
\hline \multirow[t]{3}{*}{ HERF } & $\mathrm{T}$ & 1.55 & 360 \\
\hline & $C+A$ & 3.33 & 1120 \\
\hline & $T+A$ & 1.32 & 190 \\
\hline$A-286$ & $\mathrm{C}$ & $1.95 * *$ & $610 * *$ \\
\hline \multirow[t]{3}{*}{ HERF } & $\mathbf{T}$ & 1.80 & 530 \\
\hline & $C+A$ & 1.70 & 350 \\
\hline & $T+A$ & 1.14 & 130 \\
\hline Nitronic 40 & $\mathrm{C}$ & 2.67 & 1200 \\
\hline \multirow[t]{3}{*}{ HERF } & $\mathrm{T}$ & 1.50 & 480 \\
\hline & $C+A$ & 2.62 & 960 \\
\hline & $T+A$ & 1.02 & 75 \\
\hline 316 & $\mathrm{C}$ & $3.51 * *$ & $1500 * *$ \\
\hline \multirow{3}{*}{ HERF } & $\mathrm{T}$ & 2.39 & 890 \\
\hline & $C+A$ & 2.97 & 950 \\
\hline & $T+A$ & 2.03 & 630 \\
\hline \multirow{4}{*}{$\begin{array}{l}\text { A-286 } \\
\text { (modified) } \\
\text { Annealed }\end{array}$} & $\mathrm{C}$ & 2.86 & 840 \\
\hline & $\mathrm{T}$ & 1.50 & 350 \\
\hline & $C+A$ & $2.79 * x$ & $680 * *$ \\
\hline & $T+A$ & $0.84 * *$ & $70 * *$ \\
\hline
\end{tabular}

* C - Control

$\mathrm{C}+\mathrm{A}-$ Control + Aged

T - Tritium Charged

$T+A=$ Tritium Charged + Aged .

** Single Specimen. All others in duplicate. 
The fracture mode tended to change from void coalescence to intergranular in al1 alloys except HERF Type 316. Fracture of annealed A-286 (modified) was partly intergranular after tritium charging and entirely intergranular after subsequent aging. Intergranular fracture was evident in isolated areas of the Nitronic 40 after tritium charging and became dominant after aging. Both Type 304L and Type A-286 stainless steels failed by mixed fracture (void coalescence and intergranular) after charging and aging, whereas only void coalescence was observed in the tritium charged specimens of these alloys.

Helium and hydrogen (tritium) damage occurred simultaneously, and no attempt was made to factor the measured damage between the two causes. The magnitudes of the two effects will change with time, as the tritium decays to helium. The data accumulated so far suggest however, that helium damage is more potent than hydrogen (tritium) damage for equal atomic concentrations of the two elements. There were decreases in $\mathrm{Jm}$ of 50 to $90 \%$ as a consequence of the 15-month aging during which time the average helium content increased by a factor of 2 and the average tritium content decreased by $4 \%$.

Distribution of the helium within the specimens has not been established as yet. In the Nitronic 40 , helium is presumably distributed in fine bubbles throughout the matrix as in the earlier specimens. There is no reason to believe that this same helium distribution should apply to the other alloys, particularly when their widely differing microstructures are taken into account. For example, fine carbo-nitride particles occur more commonly in Nitronic 40 than in Type $304 \mathrm{~L}$ or Type 316 stainless steels, and both varieties of A-286 may contain gamma prime ( $\mathrm{Ni}_{3}[\mathrm{Al}, \mathrm{Ti}]$, eta $\left(\mathrm{Ni}_{3} \mathrm{Ti}\right)$ and $\mathrm{TiC}$ phases in varying quantities and distributions. All of these phases could act as traps for tritium and thus create localized high helium concentrations or bubbles which would be distributed within the alloy in the same manner as the phases. Severity of helium damage would be related then to trap characteristics such as, quantity of trapped tritium at the interface, interface coherency and whether the trap were reversible or irreversible. However, the relation between helium damage and the trap characteristics need not be the same as between hydrogen damage and trap characteristics because the strain fields of helium and hydrogen differ and hydrogen is chemically reactive. 
Substantial progress has been made in identifying important material and processing variables which influence hydrogen compatibility of stainless steels. The results provide guidance in alloy selection and thermomechanical processing for a limited range of hydrogen pressures (to $69 \mathrm{MPa}$ ), operating temperatures $(78-400 \mathrm{~K}$ ), and mechanical loading conditions (constant or rising load). However, there are service conditions for which data are inadequate to allow selection of a reliable alloy or prediction of its service 1 ife.

Several unresolved issues remain that are important to uti1ization of stainless steel in environments where hydrogen isotopes are present:

- The relative importance of base alloy composition, precipitate structure and morphology, and mechanical processing in attaining high strength ( $>900 \mathrm{MPa}$ yield strength) with good hydrogen compatibility $\left(\mathrm{K}_{\mathrm{TH}}>80 \mathrm{MPa} \sqrt{\mathrm{m}}\right)$ is not certain.

- Selection of alloys for low hydrogen pressure (0.01 to $10 \mathrm{MPa})$ applications has not been systematically examined. Pressure limits and acceptable temperature ranges have not been correlated with service life and stress states for low pressure service, particularly at elevated temperatures ( $T>400 \mathrm{~K}$ ) where hydrogen attacks occur and creep conditions are encountered.

- Segregation of alloy elements, impurities, and hydrogen can adversely affect hydrogen compatibility in an alloy otherwise acceptable for a given service. The relationships of segregation to hydrogen compatibility on the one hand and to processing variables and control on the other have not been examined in detail.

- Mechanical test techniques need to be analyzed and compared to permit selection of those methods which best relate to and predict hydrogen compatibility for given service conditions (loading, hydrogen pressure, and temperature). J-integral methods were investigated to characterize ductile fracture and hydrogen degradation of tough alloys such as austentic stainless steels. Initial results were encouraging and suggest continued development of experimental and analytical procedures. 
- Mechanisms of hydrogen-assisted fracture and low temperature helium embrittlement are not known. Several hypotheses have been advanced to account for each form of degradation, but there are as yet no generally accepted explanations for these phenomena.

- Material, processing, and environmental conditions controlling helium embritt lement are not well known. Experiments have begun to examine systematically the phenomenon of low temperature hel ium embrittlement.

Investigation of hydrogen effects on the mechanical behavior of stainless steels is continuing at the Savannah River Laboratory. The issues identified above serve in part to guide the research activity. 
This report includes work by several investigators in the Savannah River Laboratory whose contributions are acknowledged: T. L. Capaletti, M. R. Dietrich, J. A. Donovan, C. W. Krapp, M. R. Louthan, Jr., D. A. Mezzanotte, L. P. McCabe, D. E. Rawl, Jr., and P. E. Zapp. The high-purity stainless steels were supplied by N. F. Fiore, Notre Dame University. Transmission microscopy of Nitronic 40 stainless steel, Figure 32, was performed by P. S. Sklad, Oak Ridge National Laboratory. 


\section{ALLOY INDEX}

Nominal compositions of alloys are shown in Table A-1. Nominal tensile properties are shown in Table A-2. Measured properties under various experimental conditions are summarized in the data sheets listed below.

I. Iron-Chromium-Nickel Alloys

$304 \mathrm{~L}$

$304 \mathrm{~N}$

$309 \mathrm{~S}$

310

316

Carpenter $20 \mathrm{Cb}-3$

Incoloy $800 \mathrm{H}$ (Huntington Alloys, Inc) Nicke1 200

Nickel 301

$440 \mathrm{C}$

II. Iron-Chromium-Nicke1-Manganese Alloys

Tenelon ${ }^{\otimes}$ (U.S. Steel Corp)

Nitronic -40 (21-6-9) (Armco, Inc)

Nitronic ${ }^{\circ}-50(22-13-5)$ (Armco, Inc)

18-18 Plus ${ }^{\otimes}$ (Carpenter Technology)

$\mathrm{X} 18-3 \mathrm{Mn}$

18-2 Mn

216

III. Precipitation Hardenable Alloys

A-286

JBK -75

17-4PH

AM-350

AM-363

CG-27

Ni-SPAN-C (Alloy 902)
Data Sheet

IA-1 to IA-16

IB-1

IC-1

ID-1 to ID-2

IE-1

IF-1

IG-1

$\mathrm{IH}-1$ to $\mathrm{IH}-2$

IJ-1 to IJ-2

IK -1

IIA-1 to IIA-3

IIB-1 to IIB-12

IIC- 1 to IIC-3

IID-1

IIE-1

IIF-1

IIG-1
IIIA- 1 to IIIA-5

IIIB-1 to IIIB-2

IIIC-1 to IIIC-2

IIID-1

IIIE-1

IIIF-1

IIIG-1

IV. High Purity Alloys
A $-18 \mathrm{Cr}-10 \mathrm{Ni}$
IVA-1
B $-18 \mathrm{Cr}-14 \mathrm{Ni}$
IVB-1
C $-18 \mathrm{Cr}-19 \mathrm{Ni}$
IVC-1 
TABLE A-1

Nominal Alloy Composition, wt $\%$

\section{A11oy}

Fe-Cr-Ni-Alloys

$304 \mathrm{~L}$
$304 \mathrm{~N}$
$309 \mathrm{~S}$
310
316
$440 \mathrm{C}$
Carpenter $20 \mathrm{Cb}-3$
I $800 \mathrm{H}$
$\mathrm{I} 718$
$\mathrm{Ni} 200$
$\mathrm{Ni} 301$

\begin{abstract}
$\underline{\mathrm{Cr}} \quad \underline{\mathrm{Ni}} \quad \underline{\mathrm{Mn}}$ Mo
\end{abstract}
Other

$\begin{array}{lllll}19 & 10 & - & - & \\ 19 & 9 & - & - & 0.13 \mathrm{~N} \\ 23 & 13 & - & - & 0.25 \mathrm{C} \\ 25 & 20 & - & - & 0.25 \\ 17 & 12 & - & 2.5 & 0.95 \mathrm{to} 1.20 \mathrm{C} \\ 19 & - & - & 0.75 & 0.5 \mathrm{Cu}, 06 \mathrm{Nb} \\ 20 & 34 & - & 2.5 & 3.5 \mathrm{Al}, 0.3 \mathrm{Ti} \\ 21 & 32 & - & - & 0.75 \mathrm{Cu}, 0.3 \mathrm{Al} \\ 19 & 52 & - & 13 & 5(\mathrm{Nb}+\mathrm{Ta}), 1 \mathrm{Ti}, 0.5 \mathrm{~A} \\ - & 99+ & - & \\ - & \text { bal } & - & 1 \mathrm{Si}, 4.5 \mathrm{Al}, 0.6 \mathrm{Ti}\end{array}$

$\mathrm{Fe}-\mathrm{Cr}-\mathrm{Ni}-\mathrm{Mn}-\mathrm{N}$ Alloys

$\begin{array}{lllllll}216 & 20 & 6 & 8 & 2 & 0.32 \mathrm{~N} \\ \text { Tenelon } & 18 & - & 15 & - & \\ \text { Nitronic } & 21 & 6 & 9 & - & 0.15 \text { to } 0.4 \mathrm{~N} \\ \text { Nitronic-50 } & 22 & 13 & 5 & 2 & 0.2 \text { to } 0.4 \mathrm{~N} & \\ 18-18 \text { Plus } & 18 & 0.5 & 18 & 1 & 0.4 \mathrm{~N}, 1 \mathrm{Cu}, 0.1 \mathrm{Co} \\ \text { X } 18-3 \mathrm{Mn} & 18 & 3 & 12 & - & 0.3 \mathrm{~N} & \\ 18-2 \mathrm{Mn} & 18 & 2 & 13 & \end{array}$

Precipitation-Hardenable Alloys

\begin{tabular}{|c|c|c|c|c|c|}
\hline $17-4 \mathrm{PH}$ & 16.5 & 4 & - & - & $4 \mathrm{Cu}, 0.3 \mathrm{Nb}$ \\
\hline$A-286$ & 15 & 26 & - & 1.25 & $2 \mathrm{Ti}, 0.25 \mathrm{Al}, 0.3 \mathrm{~V}$ \\
\hline $\mathrm{JBK}-75$ & 15 & 30 & - & 1.25 & $\begin{array}{l}2 \mathrm{Ti}, 0.25 \mathrm{Al}, \\
0.001 \mathrm{~B}, 0.25 \mathrm{~V}\end{array}$ \\
\hline AM 363 & 11.5 & 4.5 & - & - & $0.5 \mathrm{Ti}$ \\
\hline CG 27 & 13 & 38 & - & 6 & $2.5 \mathrm{Ti}, 1.6 \mathrm{Al}, 0.6 \mathrm{Nb}$ \\
\hline AM 350 & 16.5 & 4.3 & - & 2.8 & $0.1 \mathrm{~N}$ \\
\hline $\mathrm{Ni}-\mathrm{SPAN}-\mathrm{C}$ & & & & & \\
\hline Alloy 902 & 5 & 42 & - & - & $0.5 \mathrm{Al}, 2.5 \mathrm{Ti}$ \\
\hline
\end{tabular}

High-Purity Alloys

$\begin{array}{llllll}\text { A } & 18 & 10 & - & - & N<0.01 \text { in all } \\ \text { B } & 18 & 14 & - & - & \text { three alloys } \\ \text { C } & 18 & 19 & - & - & \end{array}$


TABLE A-2

Nominal Tensile Properties (Annealed Material

Unless Otherwise Noted)

\begin{tabular}{|c|c|c|c|}
\hline Al1oy & $\frac{\text { Strength, }}{\text { Yield* }}$ & $\frac{\text { MPa }}{\text { Tensile }}$ & Elongation, \% \\
\hline $304 \mathrm{~L}$ & $230-270$ & $540-560$ & $55-60$ \\
\hline $304 \mathrm{~N}$ & $290-330$ & 620 & $50-55$ \\
\hline $309 \mathrm{~s}$ & $275-310$ & $620-650$ & 45 \\
\hline 310 & 310 & 650 & $45-50$ \\
\hline 316 & $207-290$ & $550-585$ & $45-50$ \\
\hline $440 \mathrm{C}$ & $450-1890$ & $760-1965$ & $2-14$ \\
\hline Carpenter $20 \mathrm{Cb}-3$ & 250 & 600 & 50 \\
\hline $\mathrm{I} 80 \mathrm{OH}$ & $140-345$ & $450-650$ & $30-50$ \\
\hline I 718 & $1180-1250$ & $1350-1400$ & 16 \\
\hline $\mathrm{Ni} 200$ & $103-207$ & $380-550$ & $40-55$ \\
\hline $\mathrm{Ni} 301$ & $210-1200$ & $620-1450$ & $15-55$ \\
\hline 216 & 428 & 745 & 50 \\
\hline Tenelon ${ }^{\otimes}$ & 570 & 930 & 56 \\
\hline Nitronic $\$-40$ & 414 & 690 & 40 \\
\hline Nitronic $\$-50$ & 448 & 828 & 45 \\
\hline 18-18 Plus & 520 & 900 & 60 \\
\hline$X 18-3 \mathrm{Mn}$ & 580 & 810 & 45 \\
\hline $18-2 \mathrm{Mn}$ & 730 & 1000 & 51 \\
\hline $17-4 \mathrm{PH}$ & 940 & 980 & 5 \\
\hline$A-286$ & 760 & 1100 & 25 \\
\hline $\mathrm{JBK}-75 * *$ & 800 & 1090 & 14 \\
\hline AM 350 & 420 & 1160 & 70 \\
\hline AM 363 & 890 & 890 & 7 \\
\hline CG 27 & 810 & 1160 & 29 \\
\hline $\begin{array}{l}\text { Ni-SPAN-C } \\
\text { A11oy } 902\end{array}$ & $760-870$ & $900-1200$ & $6-25$ \\
\hline $\begin{array}{l}\text { * } 0.2 \% \text { offset. } \\
\text { ** HERF \& Age. }\end{array}$ & & & \\
\hline
\end{tabular}


IRON-CHROMIUM-NICKEL ALLOYS

DATA SHEET IA-1

Type 304L Stainless Steel Bar Stock, As Received*

\begin{tabular}{|c|c|c|c|c|c|c|c|}
\hline \multicolumn{2}{|c|}{ Test Condition } & \multirow{2}{*}{$\begin{array}{l}\text { Hydrogen** } \\
\text { Exposure }\end{array}$} & \multicolumn{2}{|c|}{ Strength, $\mathrm{MPa}$} & \multicolumn{2}{|c|}{ Elongation, $\%$} & \multirow{2}{*}{$\begin{array}{l}\text { Fracture } \\
\text { Strain } \\
\end{array}$} \\
\hline Temp, $\mathrm{K}$ & Environ. & & Yield & Ultimate & Uniform & Tota1 & \\
\hline 380 & AIR & $\begin{array}{l}\text { NONE } \\
69 \mathrm{MPa}\end{array}$ & $\begin{array}{l}240 \\
260\end{array}$ & $\begin{array}{l}680 \\
730\end{array}$ & $\begin{array}{l}58 \\
60\end{array}$ & $\begin{array}{l}69 \\
70\end{array}$ & $\begin{array}{l}1.78 \\
1.27\end{array}$ \\
\hline 273 & AIR & $\begin{array}{l}\text { NONE } \\
69 \mathrm{MPa}\end{array}$ & $\begin{array}{l}310 \\
330\end{array}$ & $\begin{array}{l}1160 \\
870\end{array}$ & $\begin{array}{l}80 \\
44\end{array}$ & $\begin{array}{l}89 \\
44\end{array}$ & $\begin{array}{l}1.56 \\
0.45\end{array}$ \\
\hline 200 & AIR & $\begin{array}{l}\text { NONE } \\
69 \mathrm{MPa}\end{array}$ & $\begin{array}{l}360 \\
390\end{array}$ & $\begin{array}{l}1500 \\
1210\end{array}$ & $\begin{array}{l}61 \\
44\end{array}$ & $\begin{array}{l}70 \\
44\end{array}$ & $\begin{array}{l}1.27 \\
0.25\end{array}$ \\
\hline 78 & LN & $\begin{array}{l}\text { NONE } \\
69 \mathrm{MPa}\end{array}$ & $\begin{array}{l}390 \\
430\end{array}$ & $\begin{array}{l}2200 \\
2100\end{array}$ & $\begin{array}{l}60 \\
59\end{array}$ & $\begin{array}{l}64 \\
65\end{array}$ & $\begin{array}{l}1.27 \\
1.27\end{array}$ \\
\hline
\end{tabular}

* Heat Analysis, Appendix D-1; Tensile B, Appendix C-2. ** Exposure conditions: $69 \mathrm{MPa}$ at $470 \mathrm{~K}$ for 1449 days.

DATA SHEET IA-2

Type 304L Stainless Steel, As Received

\begin{tabular}{|c|c|c|c|}
\hline Temp, $\mathrm{K}$ & Environ. & Exposure & Energy, J \\
\hline 298 & AIR & $\begin{array}{l}\text { NONE } \\
17.9 \mathrm{MPa}\end{array}$ & $\begin{array}{l}194 \\
185\end{array}$ \\
\hline 78 & AIR & $\begin{array}{l}\text { NONE } \\
17.9 \mathrm{MPa}\end{array}$ & $\begin{array}{l}165 \\
110\end{array}$ \\
\hline
\end{tabular}

* $17.9 \mathrm{MPa}$ hydrogen pressure at $470 \mathrm{~K}$ for 1000 hours. 
DATA SHEET IA-3

Effect of Test Environment on Tensile Properties

of Type 304L Stainless Steel Tubes*

Exposure Conditions

Gas Temp, $\mathrm{K}$ Time,

Tensile Properties

\begin{tabular}{|c|c|c|c|c|c|}
\hline Gas & $\mathbf{K}$ & log & & & \\
\hline He & 425 & 32 & 270 & 560 & 59 \\
\hline $\mathrm{H}_{2}$ & 425 & 32 & 320 & 480 & 19 \\
\hline $\mathrm{T}_{2}$ & 425 & 32 & 300 & 490 & 22 \\
\hline $\mathrm{H}_{2}$ & 425 & 8 & 260 & 490 & 26 \\
\hline $\mathrm{T}_{2}$ & 425 & 8 & 250 & 490 & 22 \\
\hline
\end{tabular}

* A11 tensile tubes tested at room temperature with $69 \mathrm{MPa}$ gas; data reported are averages of at least two samples.

DATA SHEET IA-4

Tensile Properties of Type 304L Stainless Steels Containing Hydrogen and Helium

\begin{tabular}{|c|c|c|c|c|c|}
\hline Test Co & & Hydrogen & Streng & $\mathrm{a}, \mathrm{MPa}$ & Elong \\
\hline Temp, K & Environment & Exposure & Yie1d & U1timate & \\
\hline 300 & Air & none & 327 & 734 & $49-56$ \\
\hline $300 *$ & Air & $* \star$ & 400 & 733 & $28-32$ \\
\hline $300 *$ & Air & $* *$ & 434 & 744 & 28 \\
\hline $973 t$ & Air & none & 152 & 237 & 31 \\
\hline $973 t$ & Air & $* *$ & 179 & 190 & 1.5 \\
\hline
\end{tabular}

* Specimens contained tritium and Helium-3.

** $328 \mathrm{~mol}$ hydrogen isotopes and $6.2 \mathrm{~mol}$ helium per $\mathrm{m}^{3}$ metal.

$\dagger 146 \mathrm{~mol}$ hydrogen isotopes and $25 \mathrm{~mol}$ helium per $\mathrm{m}^{3}$ metal. Held $1 / 2$ hour at $973 \mathrm{~K}$ before testing. 
DATA SHEET IA-5

Type 304L Stainless Steel, High Energy Rate Forged*

\begin{tabular}{|c|c|c|c|c|c|c|c|}
\hline \multicolumn{2}{|c|}{ Test Condition } & \multirow{2}{*}{$\begin{array}{l}\text { Hydrogen } \\
\text { Exposure }^{* *}\end{array}$} & \multicolumn{2}{|c|}{ Strength, $\mathrm{MPa}$} & \multicolumn{2}{|c|}{ Elongation, \% } & \multirow{2}{*}{$\begin{array}{l}\text { Fracture } \\
\text { Strain } \\
\end{array}$} \\
\hline Temp, $\bar{K}$ & Environ. & & Yield & U1timate & Uniform & Total & \\
\hline \multirow[t]{2}{*}{380} & Air & None & 440 & 630 & 32 & 44 & 1.72 \\
\hline & & $69 \mathrm{MPa}$ & 440 & 650 & 32 & 43 & 1.63 \\
\hline \multirow[t]{2}{*}{298} & Air & None & 480 & 930 & 57 & 68 & 2.00 \\
\hline & & $69 \mathrm{MPa}$ & 510 & 990 & 55 & 62 & 0.95 \\
\hline \multirow[t]{2}{*}{250} & Air & None & 490 & 1100 & 52 & 61 & 1.65 \\
\hline & & $69 \mathrm{MPa}$ & 610 & 1120 & 41 & 41 & 0.40 \\
\hline \multirow[t]{2}{*}{200} & Air & None & 660 & 1390 & 46 & 55 & 1.37 \\
\hline & & $69 \mathrm{MPa}$ & 620 & 1300 & 43 & 44 & 0.38 \\
\hline
\end{tabular}

* Tensile B, Appendix C-2.

** Exposed at $620 \mathrm{~K}$ for 3 weeks.

DATA SHEET IA-6

Type 304L Stainless Steel, High Energy Rate Forged*

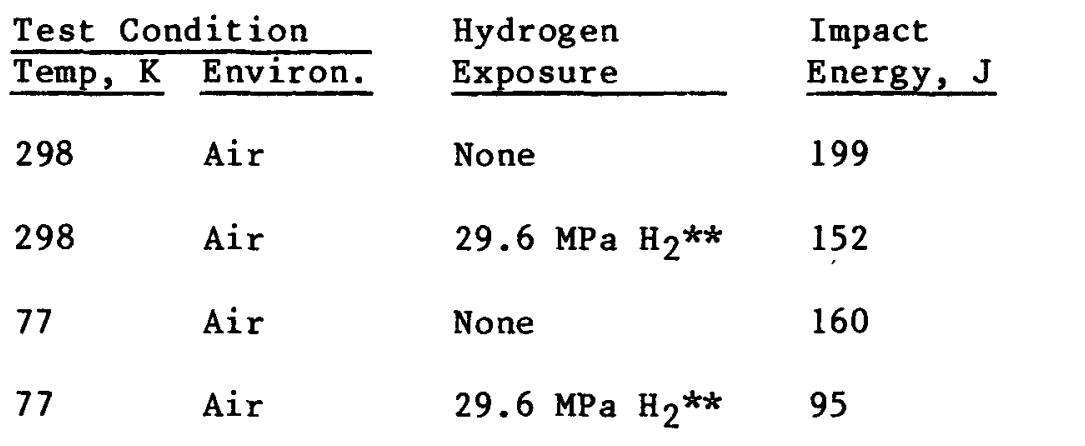

* Impact, Appendix C-8.

** Exposure of 56 days at $470 \mathrm{~K}$. 


\section{DATA SHEET IA-7}

Fracture Parameters for Type 304L Stainless Steel, High Energy Rate Forged*

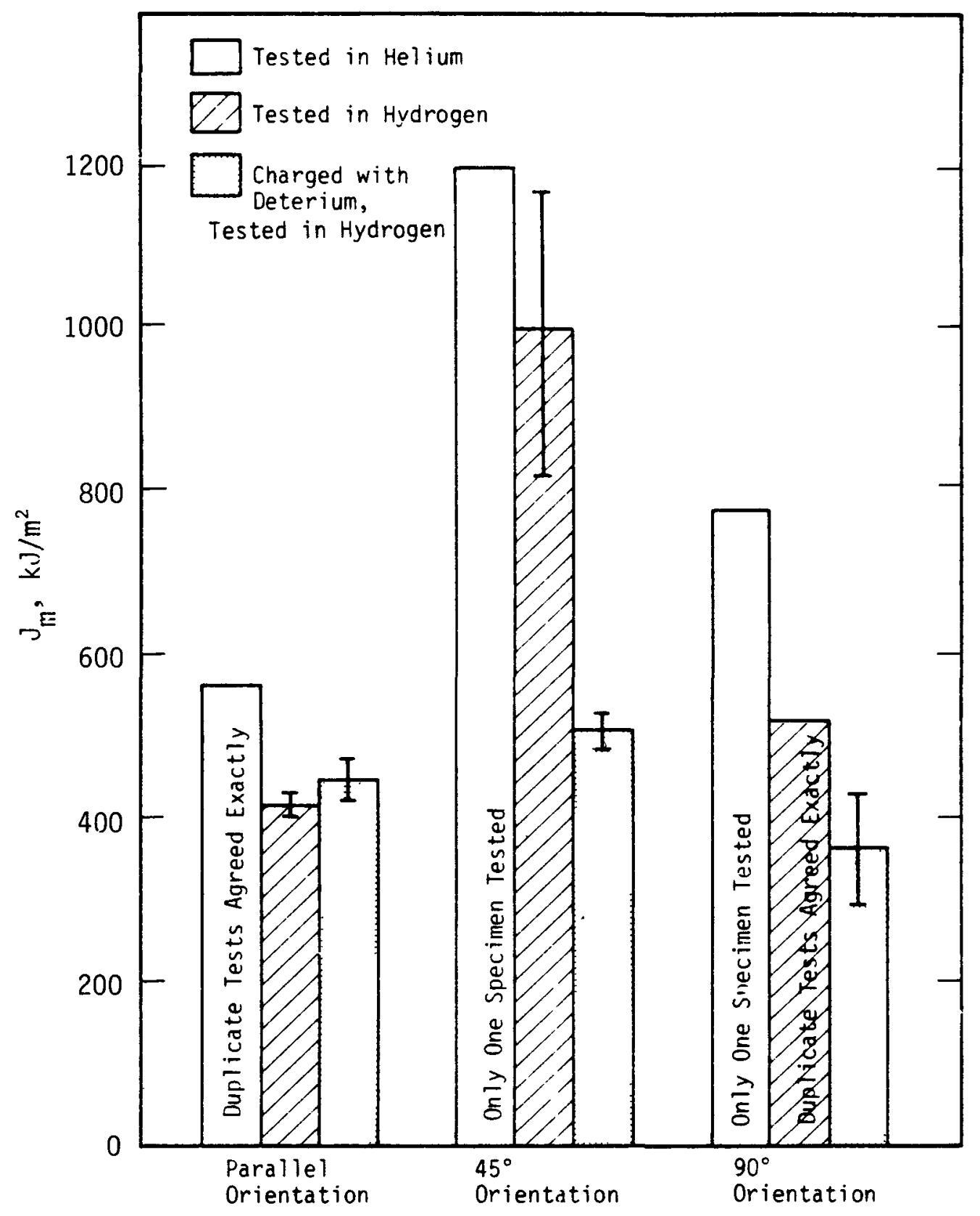

* C-shaped tensile, Appendix C-7. Test in $69 \mathrm{MPa} \mathrm{He}$ or $\mathrm{H}_{2}$. Deuterium charge at $69 \mathrm{MPa}$ at $620 \mathrm{~K}$ for 3 weeks. 


\section{DATA SHEET IA-8}

Fracture Parameters for Type 304L Stainless Steel*

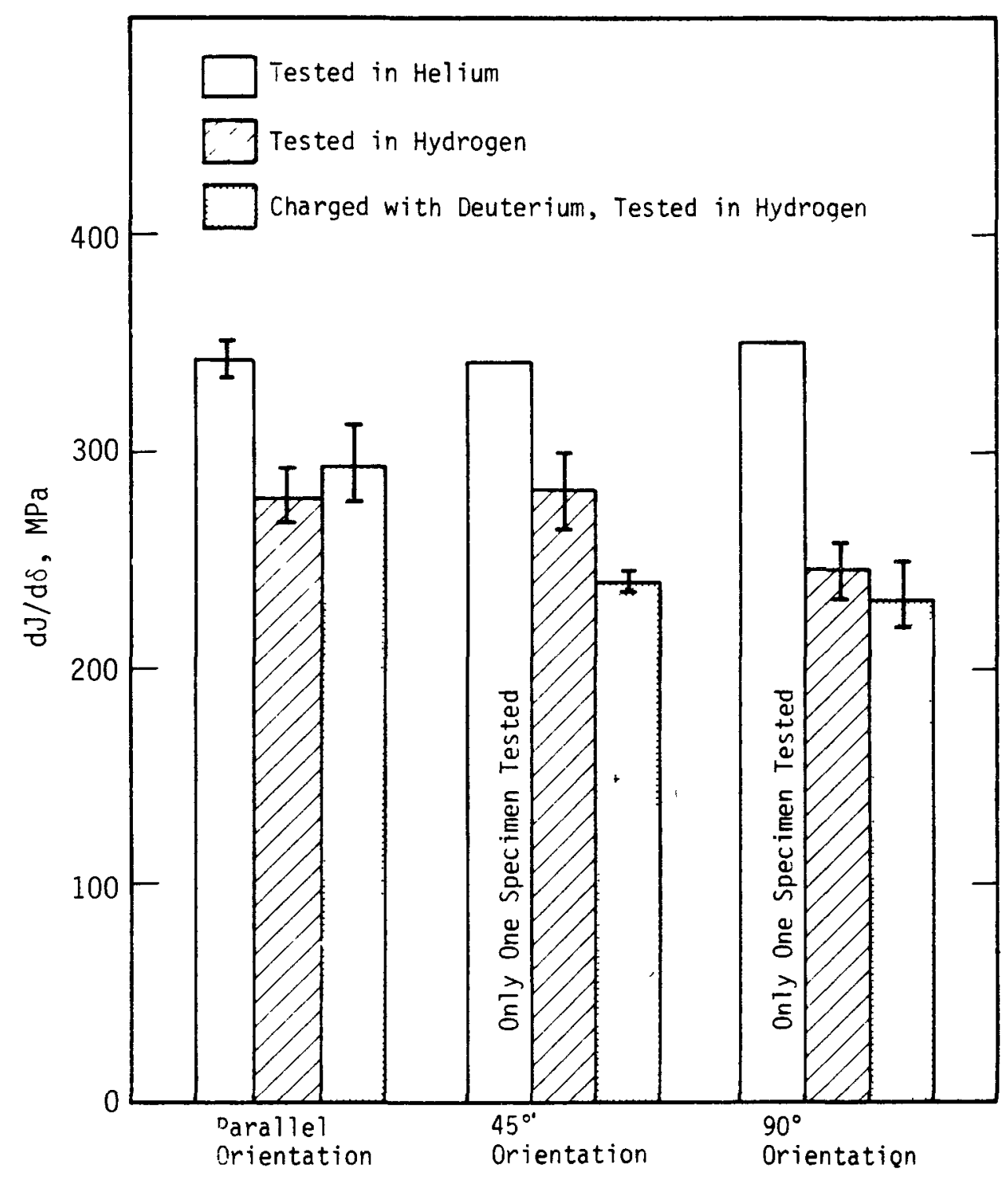

* C-shaped tensile, Appendix C-7. Test in $69 \mathrm{MPa} \mathrm{He}$ or $\mathrm{H}_{2}$. Deuterium charge at $69 \mathrm{MPa}$ at $620 \mathrm{~K}$ for 3 weeks. 
DATA SHEET IA-9

Effect of Heat Treatment on Mechanical Properties of Type 304L Stainless Stee1*

\begin{tabular}{|c|c|c|c|c|c|c|}
\hline $\begin{array}{l}\text { Heat } \\
\text { Treatment }\end{array}$ & $\begin{array}{l}\text { Test } \\
\text { Environment }\end{array}$ & $\frac{\text { Streng }}{\text { Yield }}$ & $\frac{\mathrm{th}, \mathrm{MPa}}{\text { U1timate }}$ & $\frac{\text { Elongati }}{\text { Uniform }}$ & $\frac{\text { on, } \%}{\text { Total }}$ & $\begin{array}{l}\text { Fracture } \\
\text { Strain } \\
\end{array}$ \\
\hline As-received & $69 \mathrm{MPa} \mathrm{He}$ & 390 & 930 & 62 & 71 & 2.21 \\
\hline GS $=9.5 \mu \mathrm{m}$ & $69 \mathrm{MPa} \mathrm{H} 2$ & 390 & 910 & 56 & 62 & 1.43 \\
\hline $1170 \mathrm{~K}-24 \mathrm{hrs}$ & $69 \mathrm{MPa} \mathrm{He}$ & 260 & 970 & 82 & 89 & 2.30 \\
\hline$G S=30 \mu \mathrm{m}$ & $69 \mathrm{MPa} \mathrm{H}_{2}$ & 240 & 970 & 88 & 94 & 1.71 \\
\hline $1270 \mathrm{~K}-24 \mathrm{hrs}$ & $69 \mathrm{MPa} \mathrm{He}$ & 250 & 970 & 90 & 99 & 2.30 \\
\hline $\mathrm{GS}=55 \mu \mathrm{m}$. & $69 \mathrm{MPa} \mathrm{H} 2$ & 240 & 930 & 86 & 91 & 1.17 \\
\hline $1470 \mathrm{~K}-24 \mathrm{hrs}$ & $69 \mathrm{MPa} \mathrm{He}$ & 190 & 830 & 81 & 88 & 2.21 \\
\hline $\mathrm{GS}=340 \mu \mathrm{m}$ & $69 \mathrm{MPa} \mathrm{H} 2$ & 180 & 830 & 84 & 88 & 1.05 \\
\hline
\end{tabular}

* Heat analysis; Appendix D-1; Tensile B, Appendix C-2.

DATA SHEET IA-10

Grain Size Dependence of Mechanical Properties - Test at $220 \mathrm{~K}^{*}$

\begin{tabular}{|c|c|c|c|c|c|c|}
\hline $\begin{array}{l}\text { Hydrogen } \\
\text { Exposure } \\
\end{array}$ & $\begin{array}{l}\text { Grain } \\
\text { Size, } \mu \mathrm{m}\end{array}$ & $\begin{array}{l}\text { Streng } \\
\text { Yield }\end{array}$ & $\frac{\mathrm{h}, \mathrm{MPa}}{\text { U1timate }}$ & $\frac{\text { Elons }}{\text { Unit }}$ & $\begin{array}{l}\text { ion, } \\
\text { Total } \\
\end{array}$ & $\begin{array}{l}\text { Fracture } \\
\text { Strain } \\
\end{array}$ \\
\hline \multirow[t]{3}{*}{ None } & 6.4 & 520 & 1310 & 56 & 63 & 1.71 \\
\hline & 42.0 & 340 & 1210 & .60 & 72 & 1.70 \\
\hline & 290 & 250 & 1130 & 55 & 63 & 1.64 \\
\hline \multirow[t]{4}{*}{$69 \mathrm{MPa} * *$} & 6.1 & 630 & 1040 & 35 & 35 & 0.27 \\
\hline & 26 & 400 & 1020 & 47 & 47 & 1.10 \\
\hline & 50 & 370 & 860 & 37 & 37 & 0.40 \\
\hline & 260 & 270 & 690 & 31 & 31 & 0.39 \\
\hline
\end{tabular}

* Heat analysis, Appendix D-1; Tensile B, Appendix C-2.

** Average deuterium contents measured on samples from the tensile specimens were $4.7 \mathrm{ccD}_{2} / \mathrm{cc}(69 \mathrm{MPa})$. 


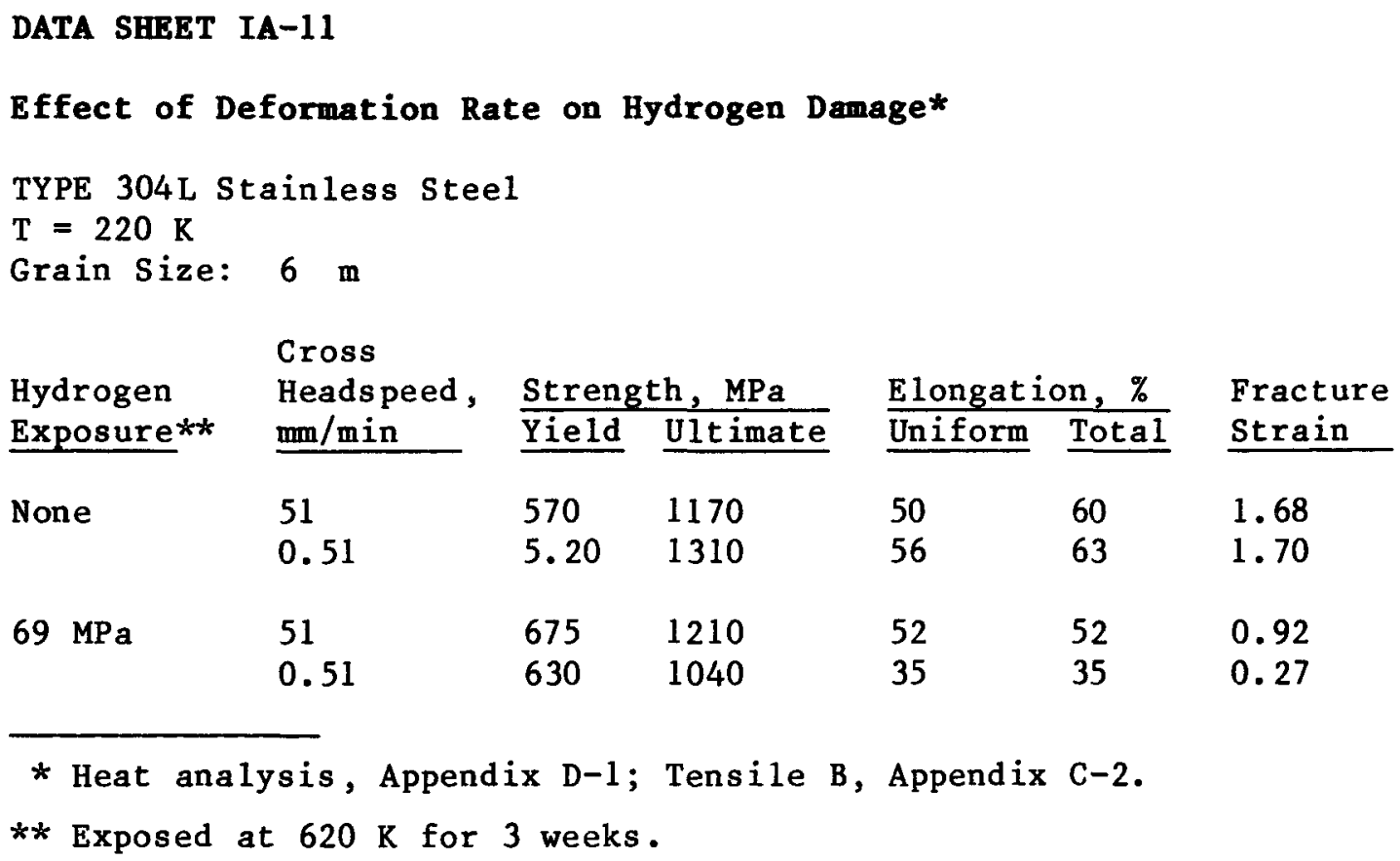

* Heat analysis, Appendix D-1; Tensile B, Appendix C-2.

** Exposed at $620 \mathrm{~K}$ for 3 weeks.

DATA SHEET IA-12

Mechanical Properties of Sensitized Type 304L Stainless Stee1* (Smooth Bar Tensile Specimens)

\begin{tabular}{|c|c|c|c|c|}
\hline \multirow[b]{2}{*}{ Treatment } & \multirow{2}{*}{$\begin{array}{l}\text { Test } \\
\text { Environment** }\end{array}$} & \multicolumn{2}{|c|}{ Strength, $\mathrm{MPa}$} & \multirow{2}{*}{$\begin{array}{l}\text { Fracture } \\
\text { Strain }\end{array}$} \\
\hline & & Yield & Ultimate & \\
\hline Solution & Air & 380 & 630 & 2.00 \\
\hline \multirow[t]{2}{*}{ Annea I } & Helium & 375 & 600 & 2.20 \\
\hline & Hydrogen & 370 & 580 & 1.38 \\
\hline \multirow[t]{4}{*}{ Sensitized } & Air & 300 & 560 & 1.78 \\
\hline & Helium & 350 & 670 & 1.90 \\
\hline & Hydrogen $\uparrow$ & 330 & 660 & 0.70 \\
\hline & Hydrogen $\dagger^{\dagger}$ & 350 & 660 & 0.80 \\
\hline
\end{tabular}

* Heat analysis, Appendix D-1; Tensile B, Appendix C-2. ** 69 MPa gas pressure.

$\dagger$ Nearly continuous carbide network on some grain boundaries. †† Isolated carbides. 
DATA SHEET IA-13

Mechanical Properties of Notch Bar Tensile Specimens of Type 304L Stainless Stee1*

\begin{tabular}{|c|c|c|c|c|}
\hline Treatment & $\begin{array}{l}\text { Test } \\
\text { Environment } \star *\end{array}$ & $\frac{\text { Stren }}{\text { Yield }}$ & $\frac{\mathrm{h}, \mathrm{MPa}}{\text { U1timate }}$ & $\begin{array}{l}\text { Fracture } \\
\text { Strain }\end{array}$ \\
\hline $\begin{array}{l}\text { Solution } \\
\text { Anneal }\end{array}$ & Airt & 700 & 750 & 0.41 \\
\hline \multirow[t]{6}{*}{ Sensitized } & Airtt & 350 & 590 & 1.26 \\
\hline & Heliumt $\dagger$ & 410 & 740 & 1.10 \\
\hline & $\begin{array}{l}\text { Hydrogentt, } \\
\text { Hydrogen If }\end{array}$ & $\begin{array}{l}430 \\
480\end{array}$ & $\begin{array}{l}590 \\
620\end{array}$ & $\begin{array}{l}0.35 \\
0.38\end{array}$ \\
\hline & Airt & 510 & 680 & 1.17 \\
\hline & Heliumt & 540 & 790 & 1.00 \\
\hline & $\begin{array}{l}\text { Hydrogent, I } \\
\text { Hydrogen II }\end{array}$ & $\begin{array}{l}730 \\
-\end{array}$ & $\begin{array}{l}750 \\
690\end{array}$ & $\begin{array}{l}0.30 \\
0.20\end{array}$ \\
\hline
\end{tabular}

* Heat analysis, Appendix $\mathrm{D}-1$ and Appendix $\mathrm{C}-2$.

** He and $\mathrm{H}_{2}$ at $69 \mathrm{MPa}$. Air at $0.1 \mathrm{MPa}$.

$t$ Deep notch.

†† Shallow notch.

I Nearly continuous carbide network on some grain boundaries.

II Isolated carbides. 
DATA SHEET IA-14

Effect of Hydrogen Charging on Notch Bar Tensile Properties of Type 304L Stainless Steel*

\begin{tabular}{lllll} 
Condition & Specimen & $\begin{array}{l}\text { Nominal Tensile } \\
\text { Strength, MPa }\end{array}$ & $\begin{array}{l}\text { Fracture } \\
\text { Strain }\end{array}$ \\
\cline { 1 - 2 } As received & $\begin{array}{llll}\text { Smooth } \\
\text { Notch }\end{array}$ & $\begin{array}{l}600 \\
770\end{array}$ & 1.50 \\
Annealed** & $\begin{array}{l}\text { Smooth } \\
\text { Notch }\end{array}$ & 600 & 0.30 \\
Hydrogen charged $t$ & $\begin{array}{l}\text { Smooth } \\
\text { Notch }\end{array}$ & 530 & 1.43 \\
& 580 & 0.24 \\
& & & 0.37 \\
\hline
\end{tabular}

* Tensile C, Appendix C-4.

** Annealed 200 days at $380 \mathrm{~K}$ in argon.

t Exposed to hydrogen gas at $69 \mathrm{MPa}$ for 200 days at $380 \mathrm{~K}$.

DATA SHEET IA-15

Type 304L Stainless Steel Notch Tensile Strength*

\begin{tabular}{|c|c|}
\hline $\begin{array}{l}\text { Test } \\
\text { Environment }\end{array}$ & $\begin{array}{l}\text { Notch Tensile } \\
\text { Strength, } \\
\text { MPa }\end{array}$ \\
\hline Air & 896 \\
\hline $\mathrm{H}_{2}, 0.1 \mathrm{MPa}$ & 786 \\
\hline $\mathrm{H}_{2}, 1.03 \mathrm{MPa}$ & 703 \\
\hline $\mathrm{H}_{2}, 6.89 \mathrm{MPa}$ & 662 \\
\hline
\end{tabular}


DATA SHEET IA-16

Stress Necessary for Slow Crack Growth in

Type 304L Stainless Steel*

\begin{tabular}{|c|c|c|c|}
\hline $\begin{array}{l}\text { Net Section } \\
\text { Stress, MN } / \mathrm{m}^{2}\end{array}$ & $\frac{\text { Time, hrs }}{\text { Incremental }}$ & Accumulated & $\begin{array}{l}\text { Crack } \\
\text { Growth }\end{array}$ \\
\hline 600 & 325 & 325 & No \\
\hline 641 & 72 & 397 & No \\
\hline 682 & 72 & 469 & No \\
\hline 724 & 72 & 541 & No \\
\hline 765 & 72 & 613 & No \\
\hline 786 & 1.4 (failed) & 614.4 & Yes \\
\hline
\end{tabular}

* Crack developed during room temperature tensile test in hydrogen environment; net section stress when tensile test was stopped was $772 \mathrm{MN} / \mathrm{m}^{2}$. Specimen then loaded in creep frame at indicated stresses without removal from the hydrogen environment.

Tensile E, Appendix C-5. 
DATA SHEET IB-1

Type 304N Stainless Steel*

\begin{tabular}{|c|c|c|c|c|c|c|c|}
\hline \multirow{2}{*}{\multicolumn{2}{|c|}{$\begin{array}{l}\text { Test Condition } \\
\text { Temp, K Environment }\end{array}$}} & \multirow{2}{*}{$\begin{array}{l}\text { Hydrogen } \\
\text { Exposure } \\
\end{array}$} & \multicolumn{2}{|c|}{ Strength, $\mathrm{MPa}$} & \multicolumn{2}{|c|}{ Elongation, \% } & \multirow{2}{*}{$\begin{array}{l}\text { Fracture } \\
\text { Strain }\end{array}$} \\
\hline & & & Yie1dt & Tensile & Uniform & Total & \\
\hline \multirow[t]{5}{*}{298} & Air & none & 760 & 880 & - & 33 & 1.24 \\
\hline & Air & $69 \mathrm{MPa} \mathrm{H}{ }^{* *}$ & 740 & 830 & - & 31 & 1.05 \\
\hline & $69 \mathrm{MPa} \mathrm{H} 2$ & none & 640 & 840 & - & 36 & 0.78 \\
\hline & $69 \mathrm{MPa} \mathrm{H} 2$ & $69 \mathrm{MPa} \mathrm{H}_{2}^{* *}$ & 550 & 790 & - & 37 & 0.62 \\
\hline & $69 \mathrm{MPa} \mathrm{He}$ & none & 630 & 850 & - & 43 & 1.35 \\
\hline \multirow[t]{2}{*}{375} & $\operatorname{Air}$ & none & 820 & 950 & 11 & 26 & 1.31 \\
\hline & & $69 \mathrm{MPa} \mathrm{D}_{2} \dagger \dagger$ & 820 & 970 & 11 & 22 & 1.20 \\
\hline \multirow[t]{2}{*}{298} & Air & none & 906 & 1110 & 16 & 28 & 1.47 \\
\hline & & $69 \mathrm{MPa} \mathrm{D}_{2}{ }^{\dagger \dagger}$ & 950 & 1185 & 16 & 28 & 0.95 \\
\hline \multirow[t]{2}{*}{245} & Air & none & 975 & 1340 & 27 & 37 & 1.82 \\
\hline & & $69 \mathrm{MPa} \mathrm{D}_{2} \dagger \dagger$ & 1063 & 1420 & 22 & 27 & 0.49 \\
\hline \multirow[t]{2}{*}{220} & Air & none & 1026 & 1450 & 26 & 35 & 1.67 \\
\hline & & $69 \mathrm{MPa} \mathrm{D}_{2} \dagger \dagger$ & 1093 & 1480 & 21 & 24 & 0.33 \\
\hline \multirow[t]{2}{*}{200} & Air & none & 1096 & 1810 & 47 & 56 & 1.44 \\
\hline & & $69 \mathrm{MPa} \mathrm{D}_{2} \dagger \dagger$ & 1160 & 1510 & 19 & 23 & 0.38 \\
\hline
\end{tabular}

* Tensile A, Appendix C-1; Heat Analysis, Appendix D-10. ** $69 \mathrm{MPa} \mathrm{H} 2$ at $430 \mathrm{~K}$ for 1000 hours.

$\dagger 0.2 \%$ offset.

†† $69 \mathrm{MPa} \mathrm{D}_{2}$ at $620 \mathrm{~K}$ for 3 weeks. 
DATA SHEET IC-1

Type 309S Stainless Stee1*

\begin{tabular}{|c|c|c|c|c|c|c|c|}
\hline \multirow{2}{*}{\multicolumn{2}{|c|}{$\frac{\text { Test Condition }}{\text { Temp, K Environment }}$}} & \multirow{2}{*}{$\begin{array}{l}\text { Hydrogen } \\
\text { Exposure }\end{array}$} & \multicolumn{2}{|c|}{ Strength, $\mathrm{MPa}$} & \multicolumn{2}{|c|}{ Elongation, \% } & \multirow{2}{*}{$\begin{array}{l}\text { Fracture } \\
\text { Strain }\end{array}$} \\
\hline & & & Yield** & Tensile & Uniform : & Total & \\
\hline \multirow[t]{5}{*}{298} & Air & none & 290 & 600 & - & 54 & 1.27 \\
\hline & $69 \mathrm{MPa} \mathrm{He}$ & none & 276 & 580 & - & 60 & 1.24 \\
\hline & $69 \mathrm{MPa} \mathrm{H} 2$ & none & 260 & 586 & - & 63 & 1.35 \\
\hline & Air & $\begin{array}{l}69 \mathrm{MPa} \mathrm{H} 2-430 \mathrm{~K} \\
14 \mathrm{~d}\end{array}$ & 255 & 615 & - & 43 & 0.92 \\
\hline & Air & $\begin{array}{l}28 \mathrm{MPa} \mathrm{H} 2^{-470 K} \\
100 \mathrm{hr}\end{array}$ & 330 & 615 & - & 57 & 1.17 \\
\hline
\end{tabular}

* Tensile A, Appendix $\mathrm{C}-1$.

** $0.2 \%$ offset.

DATA SHEET IC-2

Tensile Properties of Type 309S Stainless Steels Containing Hydrogen and Helium

\begin{tabular}{|c|c|c|c|c|c|}
\hline \multirow{2}{*}{\multicolumn{2}{|c|}{$\frac{\text { Test Condition }}{\text { Temp } K \text { Environment }}$}} & \multirow{2}{*}{$\begin{array}{l}\text { Hydrogen } \\
\text { Exposure } \\
\end{array}$} & \multicolumn{2}{|c|}{ Strength, $\mathrm{MPa}$} & \multirow{2}{*}{$\begin{array}{l}\text { Elongation, } \\
\%\end{array}$} \\
\hline & & & Yield & U1timate & \\
\hline 300 & Air & none & 243 & 612 & 56 \\
\hline $300 *$ & Air & ** & 301 & 618 & $48-57$ \\
\hline $300 *$ & Air & $\dagger$ & 382 & 658 & $45-53$ \\
\hline $973+t$ & Air & none & 131 & 296 & 27 \\
\hline $973+t$ & Air & $\dagger$ & 227 & 196 & $<1$ \\
\hline
\end{tabular}

* Specimens contained tritium and Helium-3.

** 328 mol hydrogen isotopes and $6.2 \mathrm{~mol}$ helium per $\mathrm{m}^{3}$ metal.

t $146 \mathrm{~mol}$ hydrogen isotopes and $2.5 \mathrm{~mol}$ helium per $\mathrm{m}^{3}$ metal.

$\dagger+$ Held $1 / 2$ hour at $973 \mathrm{~K}$ before testing. 
DATA SHEET ID-1

Type 310 Stainless Steel Bar Stock, As Received*

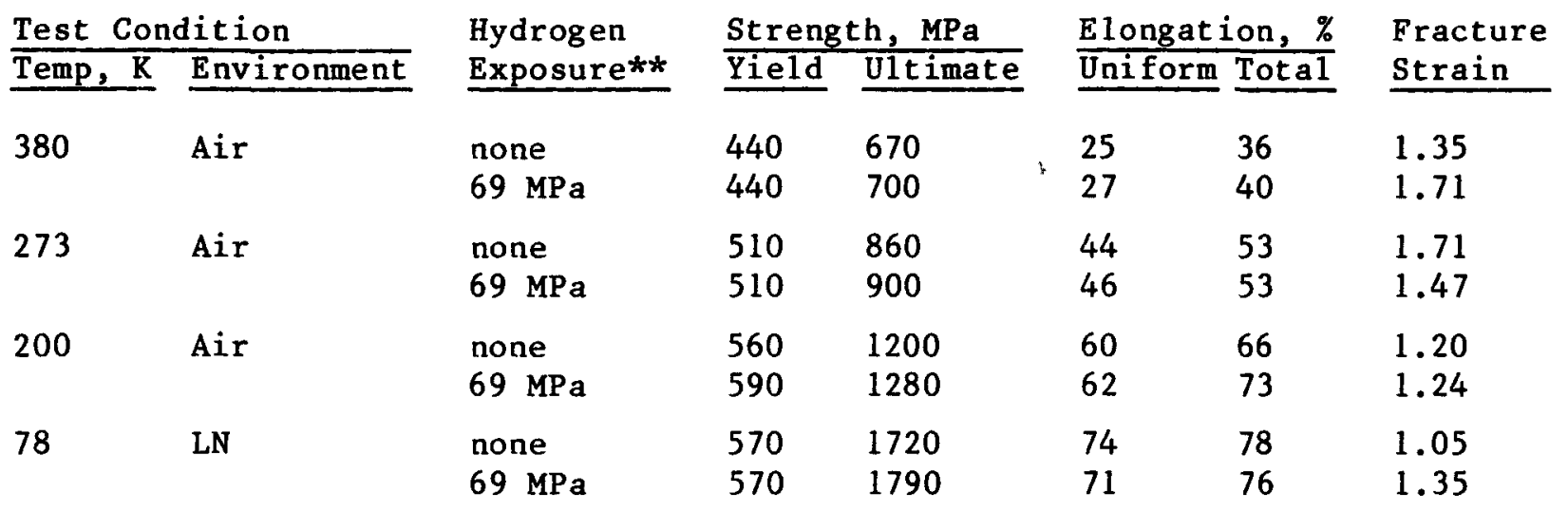

* Tensile B, Appendix C-2.

** Exposed at $470 \mathrm{~K}$ for 1449 days.

DATA SHEET ID-2

Type 310 Stainless Stee1*

\begin{tabular}{|c|c|c|c|c|c|c|c|}
\hline & \multirow{2}{*}{$\begin{array}{l}\text { Hydrogen } \\
\text { Exposure }\end{array}$} & \multicolumn{2}{|c|}{ Strength, $\mathrm{MPa}$} & \multicolumn{2}{|c|}{ Elongation, $\%$} & \multirow{2}{*}{$\begin{array}{l}\text { Fracture } \\
\text { Strain }\end{array}$} \\
\hline Temp, $\mathrm{K}$ & Environment & & Yield** & Tensile & Uni & Tota1 & \\
\hline \multirow[t]{5}{*}{298} & Air & none & 210 & 540 & - & 61 & 1.56 \\
\hline & Air & $69 \mathrm{MPa} \mathrm{H}{ }^{\dagger}$ & 200 & 500 & - & 63 & 1.42 \\
\hline & $69 \mathrm{MPa} \mathrm{H} 2$ & none & 186 & 490 & - & 67 & 1.72 \\
\hline & $69 \mathrm{MPa} \mathrm{H}_{2}$ & $69 \mathrm{MPa} \mathrm{H}{ }^{\dagger}$ & 180 & 440 & - & 66 & 1.56 \\
\hline & $69 \mathrm{MPa} \mathrm{He}$ & none & 180 & 480 & - & 70 & 1.61 \\
\hline
\end{tabular}

\footnotetext{
* Tensile A, Appendix $\mathrm{C}-1$.

$* * 0.2 \%$ offset.

$\dagger 69 \mathrm{MPa} \mathrm{H}_{2}$ at $430 \mathrm{~K}$ for 1000 hours.
} 
DATA SHEET IE-1

Type 316 Stainless Steel; Bar Stock, As Received*

\begin{tabular}{|c|c|c|c|c|c|c|c|}
\hline Test Cor & tian & Hydrogen & Streng & $\mathrm{h}, \mathrm{MPa}$ & Elongat & ion, \% & Fracture \\
\hline Temp, $\mathrm{K}$ & Environment & Exposure** & Yield & Ultimate & Uniform & Total & Strain \\
\hline 380 & Air & none & 810 & 830 & 7 & 20 & 1.61 \\
\hline & & $69 \mathrm{MPa}$ & 880 & 930 & 11 & 22 & 1.19 \\
\hline 273 & Air & none & 890 & 1040 & 21 & 33 & 1.47 \\
\hline & & $69 \mathrm{MPa}$ & 990 & 1160 & 20 & 32 & 1.13 \\
\hline 250 & Air & none & 900 & 1150 & 27 & 40 & 1.51 \\
\hline & & $69 \mathrm{MPa}$ & 1030 & 1280 & 24 & 35 & 1.07 \\
\hline 200 & Air & none & 960 & 1210 & 24 & 43 & 1.56 \\
\hline & & $69 \mathrm{MPa}$ & 1100 & 1410 & 26 & 37 & 1.06 \\
\hline
\end{tabular}

* Tensile B, Appendix C-2.

** Exposed at $620 \mathrm{~K}$ for 3 weeks. 
DATA SHEET IF-1

Carpenter $20 \mathrm{Cb}-3^{\circ}$ Stainless Steel As-Received*

\begin{tabular}{|c|c|c|c|c|c|c|c|}
\hline \multirow{2}{*}{\multicolumn{2}{|c|}{$\frac{\text { Test Condition }}{\text { Temn }}$}} & \multirow{2}{*}{$\begin{array}{l}\text { Hydrogen } \\
\text { Exposure**}\end{array}$} & \multicolumn{2}{|c|}{ Strength, $\mathrm{MPa}$} & \multicolumn{2}{|c|}{ Elongation, \% } & \multirow{2}{*}{$\begin{array}{l}\text { Fracture } \\
\text { Strain }\end{array}$} \\
\hline & & & Yiel & Ultimate & Uniform & Total & \\
\hline \multirow[t]{3}{*}{298} & Air & none & 236 & 600 & - & 48 & 1.14 \\
\hline & $69 \mathrm{MPa} \mathrm{H}_{2}$ & none & 230 & 590 & - & 48 & 1.14 \\
\hline & $69 \mathrm{MPa} \mathrm{H}_{2}$ & $69 \mathrm{MPa} \mathrm{D}_{2}$ & 262 & 610 & - & 48 & 1.14 \\
\hline \multirow[t]{2}{*}{200} & Air & none & 320 & 1100 & 60 & 66 & 1.01 \\
\hline & Air & $69 \mathrm{MPa} \mathrm{D}_{2}$ & 348 & 1177 & 55 & 62 & 1.08 \\
\hline
\end{tabular}

* Tensile B, Appendix C-2; heat analysis, Appendix D-11.

** Exposed at $620 \mathrm{~K}$ for 3 weeks.

$\dagger 0.2 \%$ offset.

DATA SHEET IG-1

Incoloy Alloy 800H, Hot Rolled Plate, Solution Annealed*

\begin{tabular}{|c|c|c|c|c|c|c|c|}
\hline est C & 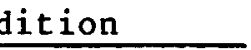 & Hydrogen & Stren & $\mathrm{h}, \mathrm{MPa}$ & Elongat i & Lon, \% & Fracture \\
\hline Temp, $\mathrm{K}$ & Environment & Exposure** & Yield & U1timate & Uniform & Total & Strain \\
\hline 380 & Air & $\begin{array}{l}\text { none } \\
69 \mathrm{MPa}\end{array}$ & $\begin{array}{l}270 \\
290\end{array}$ & $\begin{array}{l}750 \\
770\end{array}$ & $\begin{array}{l}47 \\
48\end{array}$ & $\begin{array}{l}52 \\
53\end{array}$ & $\begin{array}{l}0.92 \\
0.82\end{array}$ \\
\hline 298 & $\operatorname{Air}$ & $\begin{array}{l}\text { none } \\
69 \mathrm{MPa}\end{array}$ & $\begin{array}{l}310 \\
330\end{array}$ & $\begin{array}{l}820 \\
840\end{array}$ & $\begin{array}{l}48 \\
48\end{array}$ & $\begin{array}{l}55 \\
53\end{array}$ & $\begin{array}{l}0.97 \\
0.78\end{array}$ \\
\hline 250 & Air & $\begin{array}{l}\text { none } \\
69 \mathrm{MPa}\end{array}$ & $\begin{array}{l}340 \\
360\end{array}$ & $\begin{array}{l}870 \\
900\end{array}$ & $\begin{array}{l}48 \\
49\end{array}$ & $\begin{array}{l}56 \\
55\end{array}$ & $\begin{array}{l}1.20 \\
0.92\end{array}$ \\
\hline 200 & Air & $\begin{array}{l}\text { none } \\
69 \mathrm{MPa}\end{array}$ & $\begin{array}{l}360 \\
380\end{array}$ & $\begin{array}{l}930 \\
990\end{array}$ & $\begin{array}{l}49 \\
54\end{array}$ & $\begin{array}{l}56 \\
63\end{array}$ & $\begin{array}{l}1.11 \\
0.94\end{array}$ \\
\hline 78 & LN & $\begin{array}{l}\text { none } \\
69 \mathrm{MPa}\end{array}$ & $\begin{array}{l}530 \\
540\end{array}$ & $\begin{array}{l}1520 \\
1490\end{array}$ & $\begin{array}{l}80 \\
74\end{array}$ & $\begin{array}{l}84 \\
76\end{array}$ & $\begin{array}{l}0.78 \\
0.69\end{array}$ \\
\hline
\end{tabular}

* Tensile B, Appendix C-2; heat analysis, Appendix D-3.

** Exposed at $620 \mathrm{~K}$ for 3 weeks. 


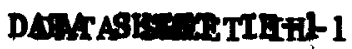

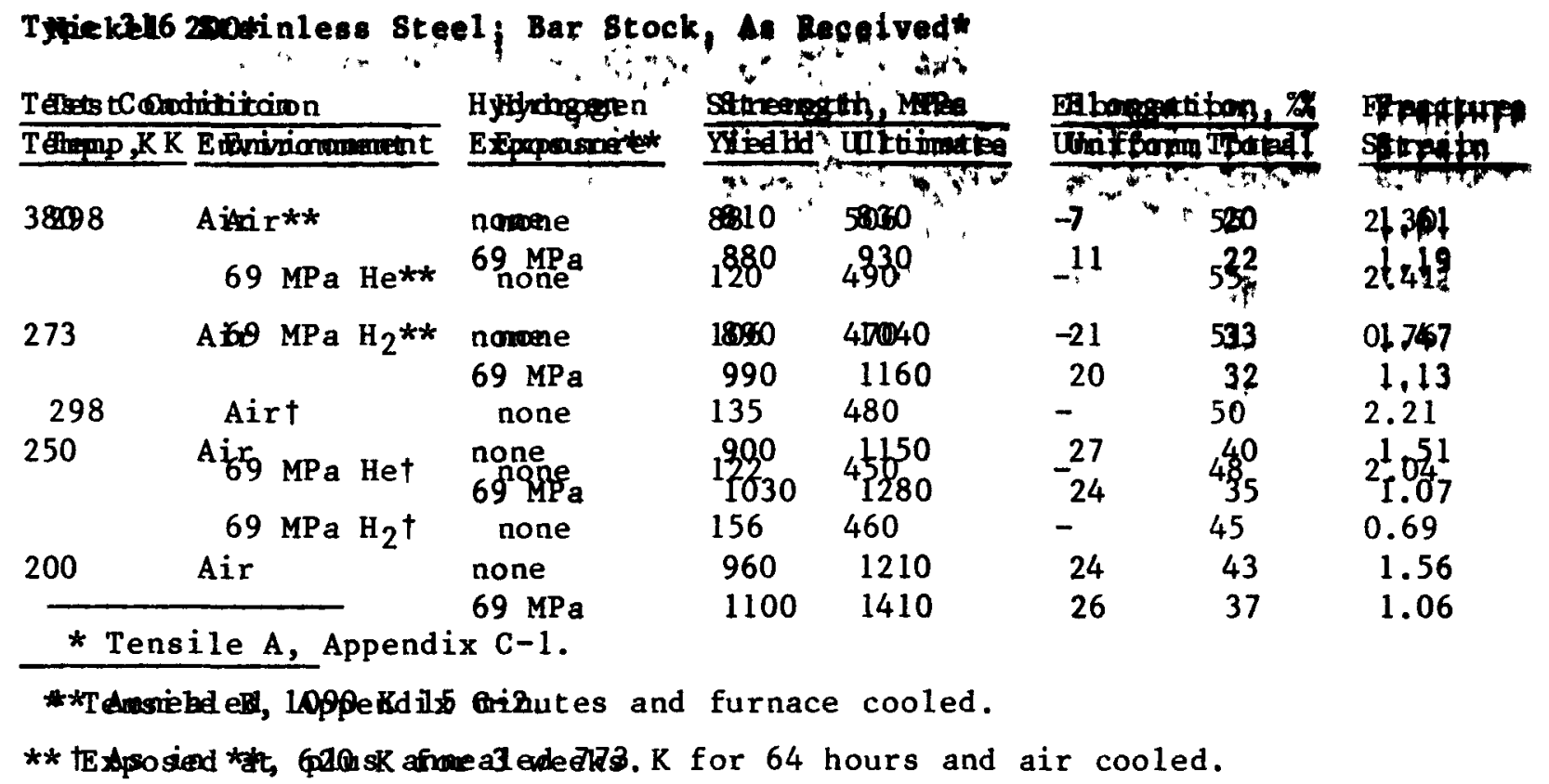

DATA SHEET IH-2

Nickel 200, Notch-Bar Tensile Properties*

\begin{tabular}{|c|c|c|c|c|c|c|c|}
\hline \multirow{2}{*}{\multicolumn{2}{|c|}{$\frac{\text { Test Condition }}{\text { Temp, } \mathrm{K} \text { Environment }}$}} & \multirow{2}{*}{$\begin{array}{l}\text { Hydrogen } \\
\text { Exposure } \\
\end{array}$} & \multicolumn{2}{|c|}{ Strength, MPa } & \multirow{2}{*}{\multicolumn{2}{|c|}{$\begin{array}{l}\text { Elongation, } \% \\
\text { Uniform Total }\end{array}$}} & \multirow{2}{*}{$\begin{array}{l}\text { Fractur } \\
\text { Strain }\end{array}$} \\
\hline & & & Yield & Ultimate & & & \\
\hline \multirow[t]{6}{*}{298} & Air** & none & - & 660 & - & - & 0.35 \\
\hline & $69 \mathrm{MPa} \mathrm{He} \star \star$ & none & - & 810 & - & - & 0.37 \\
\hline & $69 \mathrm{MPa} \mathrm{H}{ }^{* *}$ & none & - & $560^{\prime}$ & - & - & 0.11 \\
\hline & $\operatorname{Air} \dagger$ & none & - & 635 & - & - & 0.44 \\
\hline & $69 \mathrm{MPa} \mathrm{Het}$ & none & - & 710 & - & - & 0.34 \\
\hline & $69 \mathrm{MPa} \mathrm{H}{ }_{2}^{\dagger}$ & none & - & 580 & - & - & 0.20 \\
\hline
\end{tabular}

* Tensile A, Appendix C-1 with notch.

** Annealed $1090 \mathrm{~K} 15$ minutes and furnace cooled.

$\dagger$ As in **, plus annealed $773 \mathrm{~K}$ for 64 hours and air cooled. 
DATA SHEET IJ-1

Nicke1 301*

\begin{tabular}{|c|c|c|c|c|c|c|c|}
\hline \multicolumn{2}{|c|}{ Test Condition } & \multirow{2}{*}{$\begin{array}{l}\text { Hydrogen } \\
\text { Exposure }\end{array}$} & \multicolumn{2}{|c|}{ Strength, MPa } & \multirow{2}{*}{\multicolumn{2}{|c|}{$\frac{\text { Elongation, } \%}{\text { Uniform Total }}$}} & \multirow{2}{*}{$\begin{array}{l}\text { Fracture } \\
\text { Strain } \\
\end{array}$} \\
\hline Temp, $\mathrm{K}$ & Environment & & Yie1d & U1timate & & & \\
\hline \multirow[t]{3}{*}{298} & Air** & none & 451 & 778 & - & 39 & 1.89 \\
\hline & $69 \mathrm{MPa} \mathrm{He**}$ & none & 486 & 791 & - & 34 & 1.35 \\
\hline & $69 \mathrm{MPa} \mathrm{H}_{2}^{* *}$ & none & 532 & 618 & - & 12 & 0.22 \\
\hline \multirow[t]{3}{*}{298} & $\operatorname{Air} \dagger$ & none & 1008 & 1380 & - & 23 & 0.49 \\
\hline & $69 \mathrm{MPa} \mathrm{Het}$ & none & 1009 & 1350 & - & 22 & 0.42 \\
\hline & $69 \mathrm{MPa} \mathrm{H} \mathrm{H}_{2}^{\dagger}$ & none & - & 850 & - & 4 & 0 \\
\hline
\end{tabular}

* Tensile A, Appendix C-1.

** Annealed $1170 \mathrm{~K}$ for $5 \mathrm{~min}$ and quenched.

$t$ Annealed as in $* *$, plus annealed $860 \mathrm{~K}$ for 16 hours, $810 \mathrm{~K}$ for 5 hours and $755 \mathrm{~K}$ for 5 hours and furnace cooled.

DATA SHEET IJ-2

Nickel 301, Notch Bar Tensile Properties*

\begin{tabular}{|c|c|c|c|c|c|c|c|}
\hline \multicolumn{2}{|c|}{ Test Condition } & \multirow{2}{*}{$\begin{array}{l}\text { Hydrogen } \\
\text { Exposure }\end{array}$} & \multicolumn{2}{|c|}{ Strength, $\mathrm{MPa}$} & \multicolumn{2}{|c|}{ Elongation, \% } & \multirow{2}{*}{$\begin{array}{l}\text { Fracture } \\
\text { Strain }\end{array}$} \\
\hline Temp, $\mathrm{K}$ & Environment & & Yie1d & U1timate & Uniform & Total & \\
\hline \multirow[t]{6}{*}{298} & $\operatorname{Air} * *$ & none & - & 985 & - & - & 0.30 \\
\hline & $69 \mathrm{MPa} \mathrm{He}$ & none & - & 995. & - & - & 0.30 \\
\hline & $69 \mathrm{MPa} \mathrm{H} 2 * *$ & none & - & 690 & - & - & 0.01 \\
\hline & Air & none & - & 1630 & - & - & 0.19 \\
\hline & $69 \mathrm{MPa} \mathrm{Het}$ & none & - & 1600 & - & - & 0.10 \\
\hline & $69 \mathrm{MPa} \mathrm{H} 2 \dagger$ & none & - & 840 & - & - & 0.04 \\
\hline
\end{tabular}

* Tensile A, Apnendix C-1 plus notch.

** Annealed $1170 \mathrm{~K}$ for $5 \mathrm{~min}$ and quenched.

$\dagger$ Annealed as in **, plus annealed $860 \mathrm{~K}$ for 16 hours, $810 \mathrm{~K}$ for 5 hours and $755 \mathrm{~K}$ for 5 hours and furnace cooled. 
DATA SHEET IR-1

Type 440C Stainless Steel*

Test Condition

Hydrogen

Strength, MPa

Elongation, \%

Fracture

Temp, K Environment

Exposure**

Yield U1timate

Uniform Total

Strain

298

Air

377

620

7.1

0.010

$69 \mathrm{MPa} \mathrm{D} 2$

$377 \quad 575$

4.6

0.006

200

Air

none

406

670

7.7

0.013

$69 \mathrm{MPa} \mathrm{D}_{2}$

450

570

4.2

0.009

* Tensile B, Appendix C-2.

** Exposure at $620 \mathrm{~K}$ for 3 weeks. 
IRON-CHROMIUM-NICKEL-MANGANESE ALLOYS

DATA SHEET IIA-1

Tenelon` Plate, As Received*

Test Condition

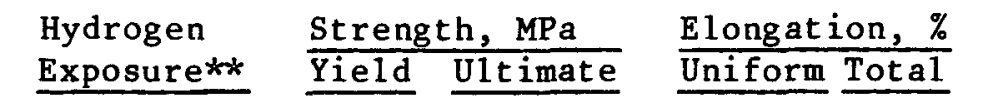

Fracture Temp, $\mathrm{K}$ Environment 675

none

$675 \quad 1270$

48

59

Strain

$350 \quad$ Air

$69 \mathrm{MPa}$

$700 \quad 1300$

1.43

273

Air

none

$830 \quad 1480$

53

60

0.94

$69 \mathrm{MPa}$

$920 \quad 1540$

50

58

1.14

$200 \quad$ Air

none

1050

1960

48

50

0.51

$69 \mathrm{MPa}$

10201620

59

66

0.69

78

LN

$\begin{array}{lll}\text { none } & 1740 & 1780 \\ \text { nonet } & 1730 & 2040 \\ \text { nonett } & 1670 & 2120 \\ \text { nonel } & 1450 & 1730 \\ 69 \mathrm{MPa} & 1720 & 1780\end{array}$

40

40

0.36

\footnotetext{
* Tensile B, Appendix C-2; heat analysis, Appendix D-4

* Exposed at $620 \mathrm{~K}$ for 3 weeks.

$\dagger$ Electropolished.

$\dagger \dagger$ Annealed $1170 \mathrm{~K}$ for 24 hours.

I Annealed $1270 \mathrm{~K}$ for 24 hours.
} 
DATA SHEET IIA-2

Tenelon

Test Condition Temp, $\mathrm{K}$ Environment

Hydrogen

Exposure

298

Air

$69 \mathrm{MPa} \mathrm{He}$

$69 \mathrm{MPa} \mathrm{H}_{2}$

Air

$69 \mathrm{MPa} \mathrm{H}_{2}$

\begin{abstract}
none
\end{abstract}
none

none

$69 \mathrm{MPa} \mathrm{H}{ }_{2}^{\dagger}$

$69 \mathrm{MPa} \mathrm{H}_{2} \dagger$
Strength, MPa

Yield** Tensile

570

930

500

875

500

900

550

840

470
Elongation, \%

Uniform Total

-
$-\quad 56$

- 65

\begin{tabular}{l}
$-\quad 55$ \\
\hline
\end{tabular}

- 41

24
Fracture

Strain

1.05

1.14

0.63

0.45

0.26

* Tensile A, Appendix $\mathrm{C}-1$.

** $0.2 \%$ of fset.

$\dagger 69 \mathrm{MPa} \mathrm{H}_{2}$ for 1000 hours at $423 \mathrm{~K}$.

DATA SHEET IIA-3

Fracture Toughness of Tenelon*

\begin{tabular}{llll}
$\begin{array}{l}\text { Test } \\
\text { Temp, K }\end{array}$ & $\begin{array}{l}\text { Specimen } \\
\text { Condition }\end{array}$ & $\begin{array}{l}\text { Fracture } \\
\text { Toughness, MPa } \sqrt{m}\end{array}$ \\
\cline { 1 - 1 } 78 & As received & 68.6 \\
& Annea1 1170 K & 36.5 \\
& Annea1 1270 K & 71.4 \\
200 & As received & 127.8 \\
& Anneal 1170 K & 99.6 \\
& Anneal 1270 K & 120.5
\end{tabular}

* Heat analysis, Appendix D-4; single edge notched, Appendix C-6. 
DATA SHEET IIB-1

\begin{tabular}{|c|c|c|c|c|c|c|c|}
\hline Test Cor & Aition & Hydrogen & Stren & th, MPa & Elongat & ion, $\%$ & Fracture \\
\hline Temp, $\mathrm{K}$ & Environment & Exposure** & Yield & U1timate & Uniform & Tota1 & Strain \\
\hline 380 & Air & none & 680 & 940 & 30 & 39 & 1.66 \\
\hline & & $69 \mathrm{MPa}$ & 690 & 1020 & 36 & 46 & 1.02 \\
\hline 298 & Air & none & 770 & 1170 & 41 & 51 & 1.61 \\
\hline & & $69 \mathrm{MPa}$ & 800 & 1270 & 46 & 56 & 0.92 \\
\hline 250 & Air & none & 860 & 1360 & 46 & 57 & 1.51 \\
\hline & & $69 \mathrm{MPa}$ & - & 1380 & 41 & 46 & 0.45 \\
\hline 200 & Air & none & 970 & 1550 & 48 & 58 & 1.56 \\
\hline & & $69 \mathrm{MPa}$ & 1060 & 1650 & 44 & 48 & 0.65 \\
\hline 78 & LN & none & 1580 & 2140 & 45 & 49 & 0.64 \\
\hline & & $69 \mathrm{MPa}$ & 1600 & 2060 & 36 & 36 & 0.38 \\
\hline
\end{tabular}

* Tensile B, Appendix C-2; heat analysis, Appendix D-5.

** Exposed at $620 \mathrm{~K}$ for 3 weeks. 
DATA SHEET IIB-2

Mechanical Properties of Nitronic 40 Alloy: Heat Treatment and Notch Effects*

Temp, $K * *$

300

200

Treatment
Solution
Anneal

Strength, $\mathrm{MPa}$

Yield U1timate

Elongation, \%

Uniform Total

Fracture

Specimen

Smooth

700

1170

41

51

Strain

bar

Notch

bar

Sensitize

Notch

bar

$800 \quad 1160$

24

$750 \quad 1070$

18

smot

Solution

Smooth
bar

$880 \quad 1550$

48

58

1.57

Notch

$1130 \quad 1500$

bar

Sensitize

$$
\text { Smoot }
$$

bar

Notch

bar

$720 \quad 1490$

19

19

0.72

1.59

0.74

0.53

51

60

1.03

10

10

0.17

* Heat analysis, Appendix D-5; Tensile B, Appendix C-2. ** Air environment. 


\section{DATA SHEET IIB-3}

Mechanical Properties of Sensitized Nitronic 40 Stainless Steel Tested in a High-Pressure Hydrogen Environment at Room Temperature*

\begin{tabular}{|c|c|c|c|c|c|c|}
\hline $\begin{array}{l}\text { Specimen } \\
\text { Condition }\end{array}$ & $\begin{array}{l}\text { Test } \\
\text { Atmosphere }\end{array}$ & $\begin{array}{l}\text { Streng } \\
\text { Yield }\end{array}$ & $\frac{\mathrm{h}, \mathrm{MPa}}{\text { Ultimate }}$ & $\frac{\text { Elong at } i}{\text { Uniform }}$ & $\frac{n, \%}{\text { Total }}$ & $\begin{array}{l}\text { Fracture } \\
\text { Strain }\end{array}$ \\
\hline \multirow{2}{*}{$\begin{array}{l}\text { Solution } \\
\text { Annealed }\end{array}$} & $69 \mathrm{MPa} \mathrm{He}$ & 650 & 1050 & 42 & 52 & 1.11 \\
\hline & $69 \mathrm{MPa} \mathrm{H} 2$ & 670 & 1060 & 41 & 50 & 1.22 \\
\hline \multirow[t]{2}{*}{$920 \mathrm{~K}-2 \mathrm{hr}$} & $69 \mathrm{MPa} \mathrm{He}$ & 640 & 1100 & 43 & 50 & 1.51 \\
\hline & $69 \mathrm{MPa} \mathrm{H} 2$ & 640 & 1080 & 42 & 49 & 1.50 \\
\hline \multirow[t]{2}{*}{$920 \mathrm{~K}-24 \mathrm{hr}$} & $69 \mathrm{MPa} \mathrm{He}$ & 625 & 1110 & 46 & 53 & 1.38 \\
\hline & $69 \mathrm{MPa} \mathrm{H}_{2}$ & 620 & 1100 & 46 & 52 & 1.10 \\
\hline \multirow[t]{2}{*}{$920 \mathrm{~K}-24 \mathrm{hr}$} & $69 \mathrm{MPa} \mathrm{He* \star}$ & 760 & 1060 & 16 & 16 & 0.32 \\
\hline & $60 \mathrm{MPa} \mathrm{H} 2^{* *}$ & 700 & 760 & 9 & 9 & 0.06 \\
\hline
\end{tabular}

* Heat analysis, Appendix D-5; Tensile B, Appendix C-2. ** Notch bar specimen.

DATA SHEET IIB-4

Mechanical Properties of Sensitized Nitronic 40 Stainless Steel Saturated with Hydrogen*

\begin{tabular}{|c|c|c|c|c|c|c|c|}
\hline Temp, $\mathrm{K}$ & Treatment** & $\begin{array}{l}\text { Hydrogen } \\
\text { Exposure }\end{array}$ & $\begin{array}{l}\text { Streng } \\
\text { Yield } \\
\end{array}$ & $\frac{h, M P a}{\text { U1timate }}$ & $\frac{\mathrm{E} 1 \mathrm{c}}{\mathrm{Un} 1}$ & $\frac{\text { ion, } \%}{\text { Total }}$ & $\begin{array}{l}\text { Fracture } \\
\text { Strain }\end{array}$ \\
\hline \multirow[t]{5}{*}{200} & $\begin{array}{l}\text { Solution } \\
\text { Anneal }\end{array}$ & none & 970 & 1550 & 48 & 58 & 1.57 \\
\hline & $\begin{array}{l}\text { Solution } \\
\text { Anneal }\end{array}$ & $69 \mathrm{MPa} \mathrm{H} \mathrm{H}_{2}^{\dagger}$ & 1060 & 1650 & 44 & 48 & 0.66 \\
\hline & $920 \mathrm{~K}-24 \mathrm{hr}$ & none & 790 & 1490 & 51 & 60 & 1.03 \\
\hline & $920 \mathrm{~K}-24 \mathrm{hr}$ & $69 \mathrm{MPa} \mathrm{H} 2$ & 920 & 1470 & 37 & 37 & 0.33 \\
\hline & $920 \mathrm{~K}-24 \mathrm{hr}$ & $69 \mathrm{MPa} \mathrm{H} \mathrm{H}_{2} \dagger$ & 900 & 1350 & 35 & 40 & 0.45 \\
\hline
\end{tabular}

* Heat analysis, Appendix D-5; Tensile B, Appendix C-2.

** Smooth bar tensile specimens.

$\dagger$ Exposed at $620 \mathrm{~K}$ for 3 weeks.

$\dagger \dagger$ Crosshead speed, $5 \mathrm{~mm} / \mathrm{sec}$; all others, $0.5 \mathrm{~mm} / \mathrm{sec}$. 
DATA SHEET IIB-5

\section{Nitronic 40 *}

Test Condition Temp, $K$ Environment

Hydrogen Strength, MPa

Exposure

298

Air

$69 \mathrm{MPa} \mathrm{He}$

$69 \mathrm{MPa} \mathrm{H}_{2}$ none

none

none
Yield** Tensile

400

350

670

700

700
Elongation, \% Fracture Uniform Total Strain

$-\quad 58 \quad 1.51$

$-\quad 59 \quad 1.47$

\begin{tabular}{l}
$-\quad 61 \quad 1.43$ \\
\hline
\end{tabular}

Tensile A, Appendix $\mathrm{C}-1$.

** $0.2 \%$ offset.

DATA SHEET IIB-6

Nitronic 40; Cold Worked 30\%*

Test Condition Temp, K Environment

Hydrogen

Exposure

298

Air

$69 \mathrm{MPa} \mathrm{He}$

$69 \mathrm{MPa} \mathrm{H}_{2}$

$69 \mathrm{MPa} \mathrm{H}_{2}$ $\begin{array}{ll}\text { none } & 1240 \\ 30 \mathrm{MPa} & 1075\end{array}$

$30 \mathrm{MPa} \mathrm{H}_{2}$

none

none

$30 \mathrm{MPa} \mathrm{H}_{2}$

1010

980

1060
Strength, MPa Yield** Tensile

\section{0}

1150

1050

1100

1130
Elongation, \% Uniform Total

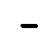

$\begin{array}{ll}- & 26 \\ - & 32\end{array}$

$-$

$-$

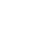

Fracture

Strain

0.87

0.43

0.99

1.02

0.44

* Tensile A, Appendix C-1.

** $0.2 \%$ offset. 
DATA SHEET IIB-7

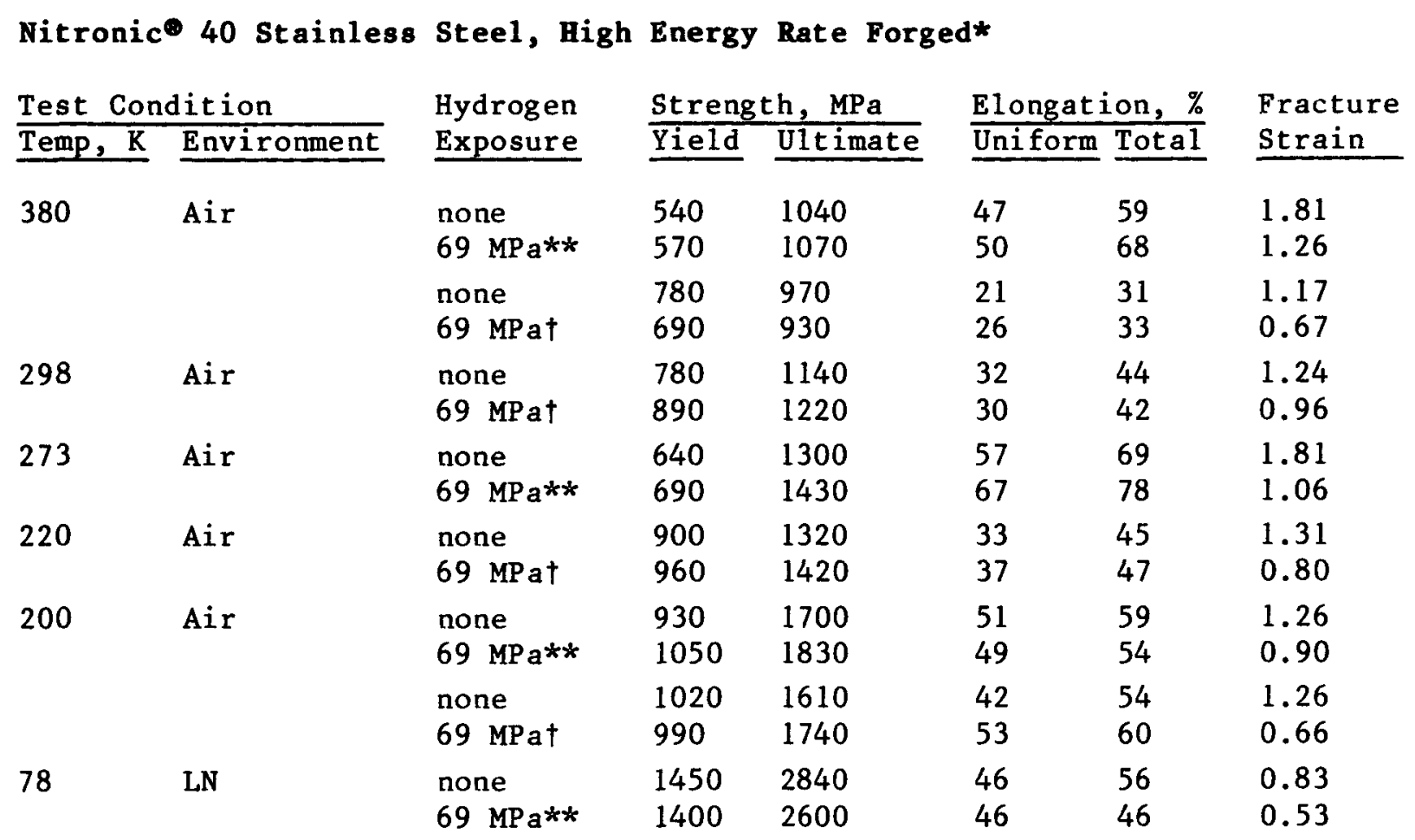

* Tensile B, Appendix C-2.

** $69 \mathrm{MPa}$ at $470 \mathrm{~K}$ for 1449 days.

$\dagger 69 \mathrm{MPa}$ at $620 \mathrm{~K}$ for 21 days.

DATA SHEET IIB-8

Nitronic 40 Stainless Steel, High Energy Rate Forged*

\begin{tabular}{|c|c|c|c|c|c|c|c|}
\hline \multirow{2}{*}{\multicolumn{2}{|c|}{$\frac{\text { Test Condition }}{\text { Temp, K Environment }}$}} & \multirow{2}{*}{$\begin{array}{l}\text { Hydrogen } \\
\text { Exposure }\end{array}$} & \multicolumn{2}{|c|}{ Strength, $\mathrm{MPa}$} & \multicolumn{2}{|c|}{ Elongation, $\%$} & \multirow{2}{*}{$\begin{array}{l}\text { Fracture } \\
\text { Strain }\end{array}$} \\
\hline & & & Yie1d** & Tensile & Uniform & Tota1 & \\
\hline \multirow[t]{5}{*}{298} & Air & none & 610 & 790 & - & 34 & 1.35 \\
\hline & & $28 \mathrm{MPa} \mathrm{H} \mathrm{H}_{2}$ & 660 & 820 & - & 31 & 0.89 \\
\hline & $69 \mathrm{MPa} \mathrm{He}$ & none & 570 & 780 & - & 34 & 1.39 \\
\hline & $69 \mathrm{MPa} \mathrm{H} 2$ & none & 570 & 790 & - & 30 & 1.31 \\
\hline & & $28 \mathrm{MPa} \mathrm{H}$ & 630 & 830 & - & 31 & 0.78 \\
\hline
\end{tabular}

* Tensile A, Appendix $\mathrm{C}-1$.

** $0.2 \%$ offset. 
DATA SHEET IIB-9

Nitronic 40 Stainless Steel, High Energy Rate Forged*

Test Condition

Hydrogen

Impact

Temp, $\mathrm{K}$ Environment

Exposure

Energy, J

298

Air

none $\quad 110$

$29.6 \mathrm{MPa} \mathrm{H}_{2} * \star \quad 91$

77

LN

none 37

$29.6 \mathrm{MPa} \mathrm{H}_{2}$ * $\quad 35$

* Impact, Appendix C-8.

** $470 \mathrm{~K}-56$ days.

DATA SHEET IIB-10

Nitronic ${ }^{\bullet} 40$ Stainless Steel, High Energy Rate Forged*

Test Condition Fracture Toughness, Temp, $\mathrm{K}$ Environment

Hydrogen $\mathrm{MPa} \sqrt{\mathrm{m}}$

Exposure Long Trans

298 $69 \mathrm{MPa} \mathrm{He}$

none

79

74

$69 \mathrm{MPa} \mathrm{H}_{2}$

none

81

68

$69 \mathrm{MPa} \mathrm{H}_{2}$

$0.6 \mathrm{MPa} \mathrm{H}_{2}$

76

62

* C-shaped tensile, Appendix $C-7$. 
DATA SHEET IIB-11

Fracture Parameters for Nitronic 40 Stainless Stee1*

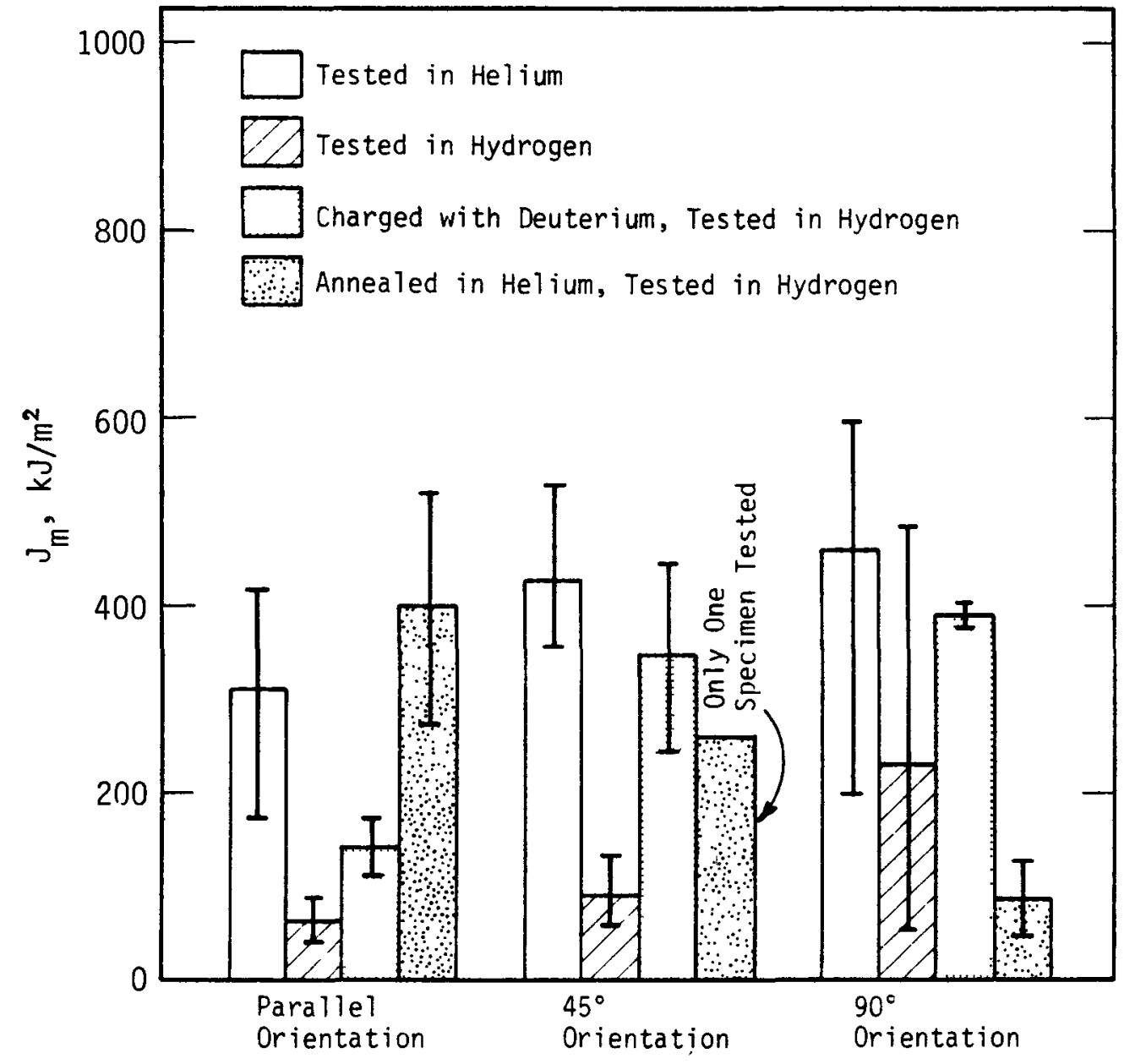

* C-shaped tensile, Appendix $\mathrm{C}-7$. Test in $69 \mathrm{MPa} \mathrm{He}$ or $\mathrm{H}_{2}$. Deuterium exposed at $69 \mathrm{MPa}$ at $620 \mathrm{~K}$ for 3 weeks. 
DATA SHEET IIB-12

Fracture Parameters for Nitronic 40 Stainless Steel*

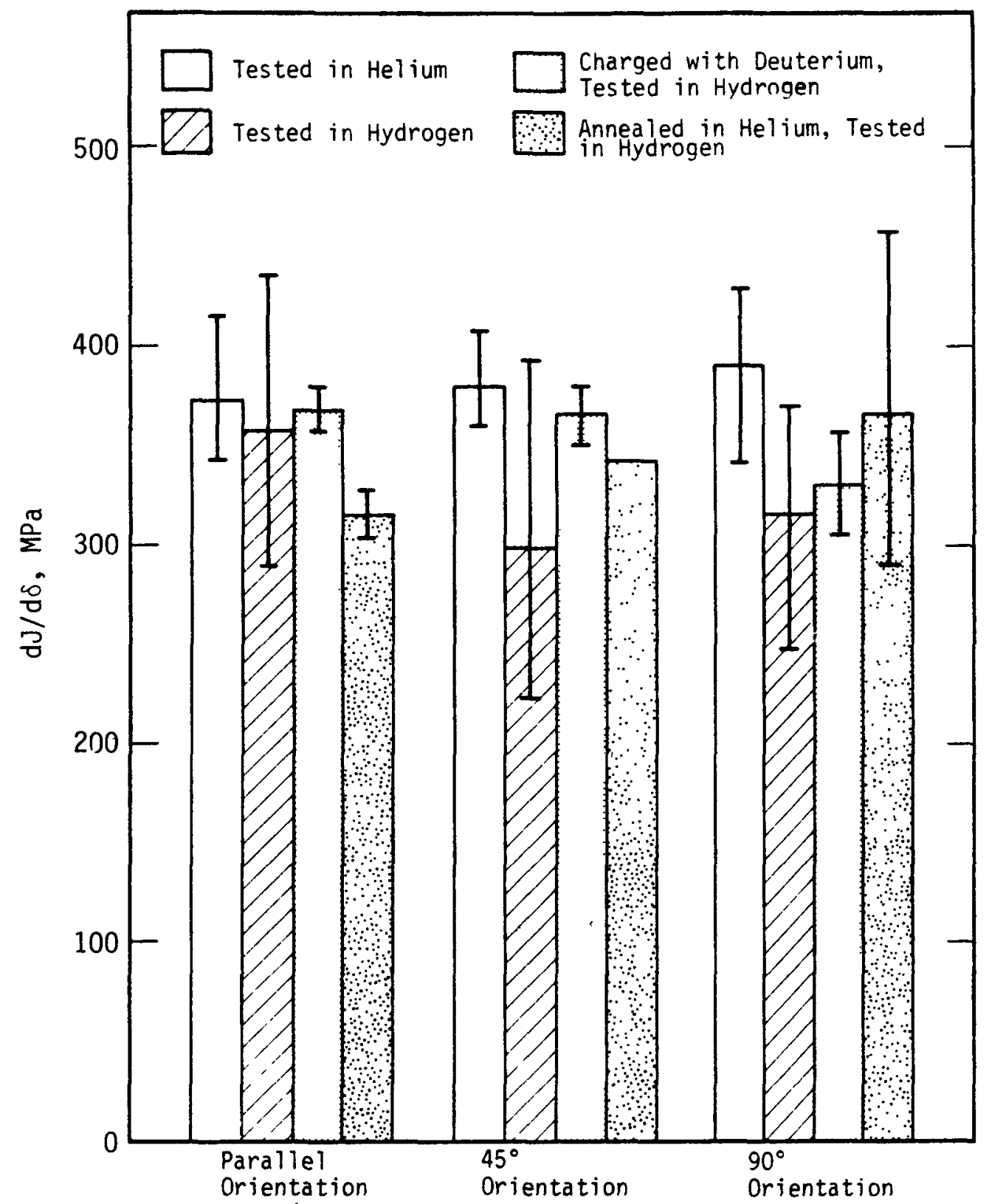

* C-shaped tensile, Appendix C-7. Test in $69 \mathrm{MPa} \mathrm{He}$ or $\mathrm{H}_{2}$. Deuterium charged at $69 \mathrm{MPa}$ at $620 \mathrm{~K}$ for 3 weeks. 
DATA SHEET IIC-1

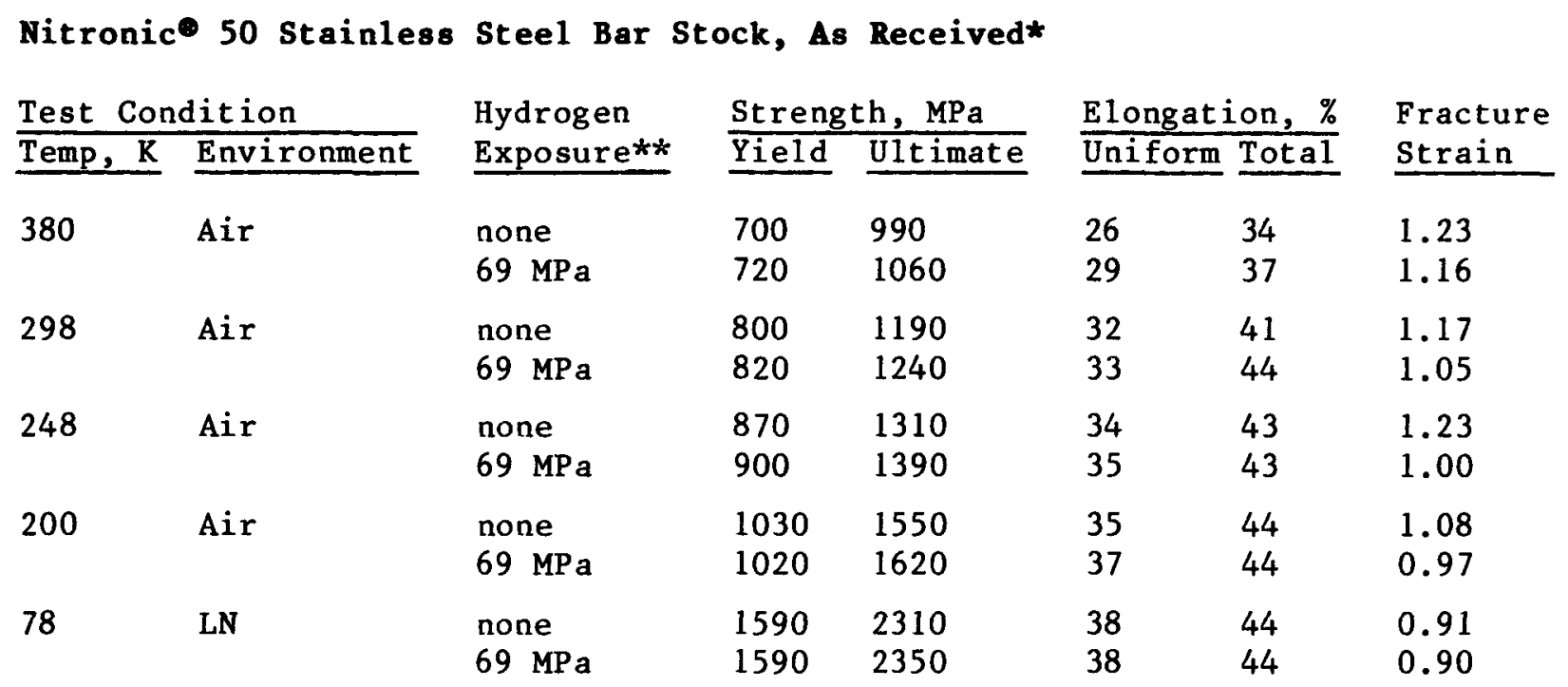

* Tensile B, Appendix C-2.

** Exposed at $620 \mathrm{~K}$ for 3 weeks.

DATA SHEET IIC-2

Nitronic 50 Stainless Steel Bar Stock, As Received.*

\begin{tabular}{|c|c|c|c|c|c|c|}
\hline$\frac{\text { Test Con }}{\text { Temp, } \mathrm{K}}$ & Environment & $\begin{array}{l}\text { Hydrogen } \\
\text { Exposure }\end{array}$ & $\frac{\text { Strength, }}{\text { Yield }{ }^{\star \star}}$ & $\frac{\mathrm{MPa}}{\text { Tensile }}$ & Elongation, \% & $\begin{array}{l}\text { Fracture } \\
\text { Strain }\end{array}$ \\
\hline \multirow[t]{3}{*}{298} & Air & none & 440 & 710 & 43 & 1.27 \\
\hline & $69 \mathrm{MPa} \mathrm{He}$ & none & 400 & 680 & 47 & 1.35 \\
\hline & $69 \mathrm{MPa} \mathrm{H} 2$ & none & 400 & 680 & 45 & 1.31 \\
\hline
\end{tabular}

* Tensile A, Appendix C-1; heat analysis, Appendix D-6.

** $0.2 \%$ offset. 
DATA SHEET IIC-3

Nitronic 50 Stainless Steel, High-Energy-Rate-Forged*

Test Condition Temp, $\mathrm{K}$ Environment

Hydrogen Deflection $\mathrm{J}_{\mathrm{m}} \mathrm{Jm} \quad \underline{\mathrm{dJ} / \mathrm{da}}$ 298

$69 \mathrm{MPa} \mathrm{He} \dagger$

$69 \mathrm{MPa} \mathrm{H}_{2}$

$69 \mathrm{MPa} \mathrm{H}_{2}$

none

23

176

$\mathrm{D}_{2}$

-

$-$

33

137

211

$69 \mathrm{MPa} \mathrm{He} \dagger$

$69 \mathrm{MPa} \mathrm{H}{ }_{2} \dagger$

none

-

none

936

360

$69 \mathrm{MPa} \mathrm{H} \mathrm{H}_{2} \dagger$

$\mathrm{D}_{2}$

$-$

107

209

181

264

* C-Shaped tensile, Appendix C-7.

** Exposed at $620 \mathrm{~K}$ for 3 weeks.

† Crack parallel to forging pattern

t† Crack perpendicular to forging patterns.

\section{DATA SHEET IID-1}

\section{8-18 Plus॰ Stainless Stee1*}

\begin{tabular}{|c|c|c|c|c|c|c|c|}
\hline Test Co & & Hydrogen & Strength & $\mathrm{MPa}$ & Elongat & on, \% & Fracture \\
\hline Temp, $\mathrm{K}$ & Environment & Exposure & Yie1d** & Tensile & Uniform & Tota1 & Strain \\
\hline 298 & $69 \mathrm{MPa} \mathrm{He}$ & none & 520 & 910 & - & 63 & 1.51 \\
\hline & $69 \mathrm{MPa} \mathrm{H} 2$ & none & 506 & 880 & - & 42 & 0.42 \\
\hline
\end{tabular}

* Tensile A, Appendix C-1; heat analysis, Appendix D-9.

** $0.2 \%$ offset. 
DATA SHEET IIE-1

X18-3 Mn Stainless Stee1*

Test Condition

\begin{tabular}{|c|c|c|c|c|c|}
\hline $\begin{array}{l}\text { Hydrogen } \\
\text { Exposure }\end{array}$ & $\frac{\text { Strength }}{\text { Yield*t }}$ & $\frac{\mathrm{MPa}}{\text { Tensile }}$ & $\frac{\text { Elongat }}{\text { Uniform }}$ & $\frac{\text { ion, } \%}{\text { Total }}$ & $\begin{array}{l}\text { Fracture } \\
\text { Strain }\end{array}$ \\
\hline none & 580 & 810 & - & 45 & 1.24 \\
\hline none & 530 & 790 & - & 50 & 1.35 \\
\hline none & 520 & 790 & - & 46 & 1.31 \\
\hline
\end{tabular}

* Tensile A, Appendix C-1; heat analysis, Appendix D-8. $* * 0.2 \%$ offset.

DATA SHEET IIF-1

18-2 Mn Stainless Steel*

Test Condition Hydrogen Exposure

Strength, MPa Elongation, \% Fracture Temp, $\mathrm{K}$ Environment

none 730 Uniform Tota1 Strain 298

Air

none

660

924

51

0.87

$69 \mathrm{MPa} \mathrm{H}_{2}$ $c-1$

* Tensile A, Appendix C-1. ** $0.2 \%$ off set. 
DATA SHEET IIG-1

Type 216 Stainless Steel*

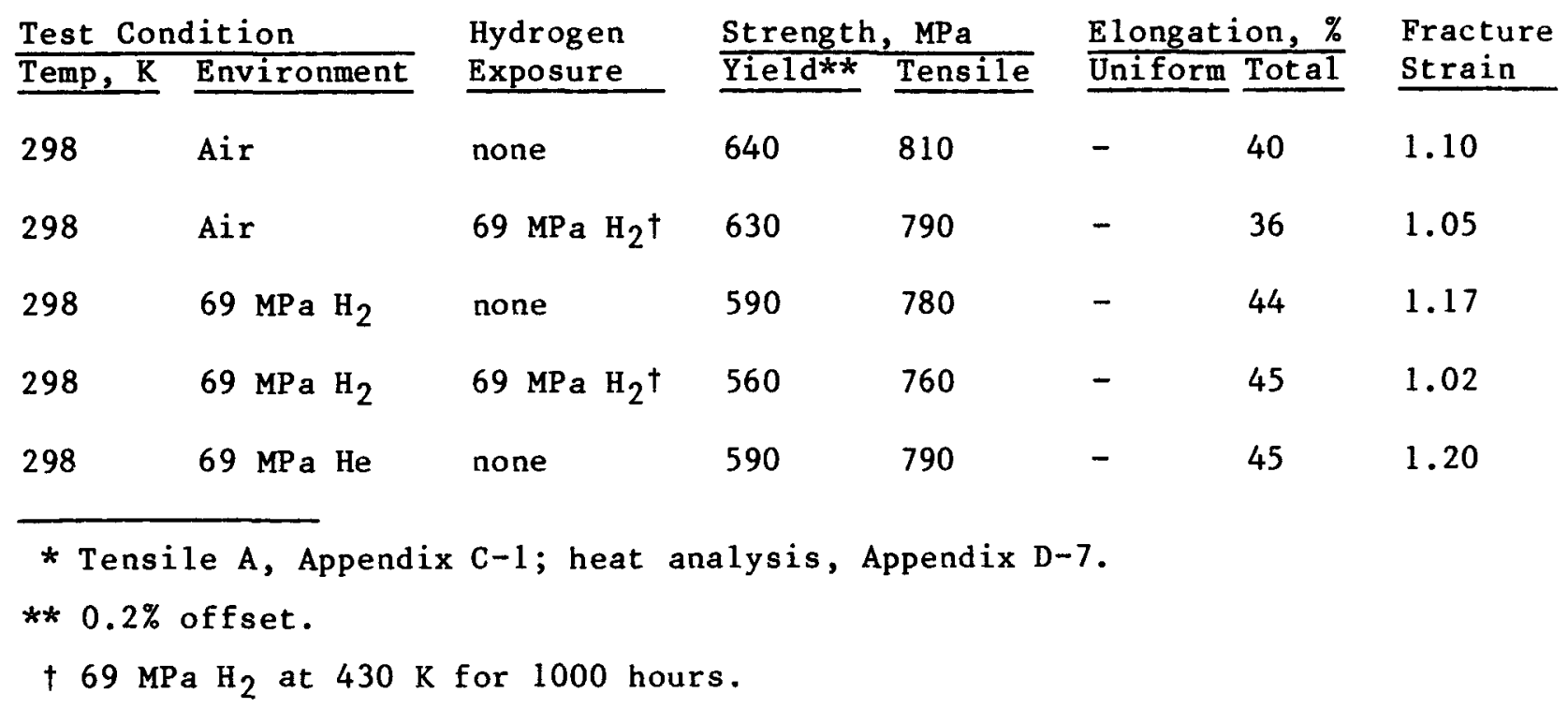


PRECIPITATION HARDENABLE ALLOYS

DATA SHEET IIIA-1

A-286 Stainless Steel*

Test Condition

Hydrogen

Temp, $\mathrm{K}$ Environment

Exposure

Strength, $\mathrm{MPa}$

Elongation, \% Fracture Yield Tensile Uniform Total Strain

298

Air

none

$765 \quad 1098$

25

0.77

2. $1 \mathrm{MPa}$ Argon

$776 \quad 1089$

24

0.79

$69 \mathrm{MPa} \mathrm{D} / \mathrm{T} * *$

$750 \quad 1041$

13

0.34

nonet

- 1500

4

0.15

2.1 MPa Argon

$-\quad 1380$

3.6

0.11

$69 \mathrm{MPa} \mathrm{D} / \mathrm{T}^{* *}, 1$ -

1310

3

0.06

none

$1010 \dagger 1350 \dagger$

$-$

3

0.50

$69 \mathrm{MPa} \mathrm{D}_{2} \|$

$1070 t \quad 1380+t$

28

0.24

220

Air

none

$1100 t \quad 1520+t$

28

0.49

$69 \mathrm{MPa} \mathrm{D}_{2}$ I

$1130 \dagger \quad 1530 \dagger \dagger$

27

34

0.25

* Tensile A, Appendix $\mathrm{C}-1$.

** $69 \mathrm{MPa} \mathrm{D} / \mathrm{T}$ at $370 \mathrm{~K}$ for 200 days.

$\dagger$ True stress at $5 \%$ strain.

†† True stress at maximum load.

I Notched-bar tensile specimens, all others smooth-bar specimens.

$1169 \mathrm{MPa} \mathrm{D}_{2}$ at $620 \mathrm{~K}$ for 3 weeks. 
DATA SHEET IIIA-2

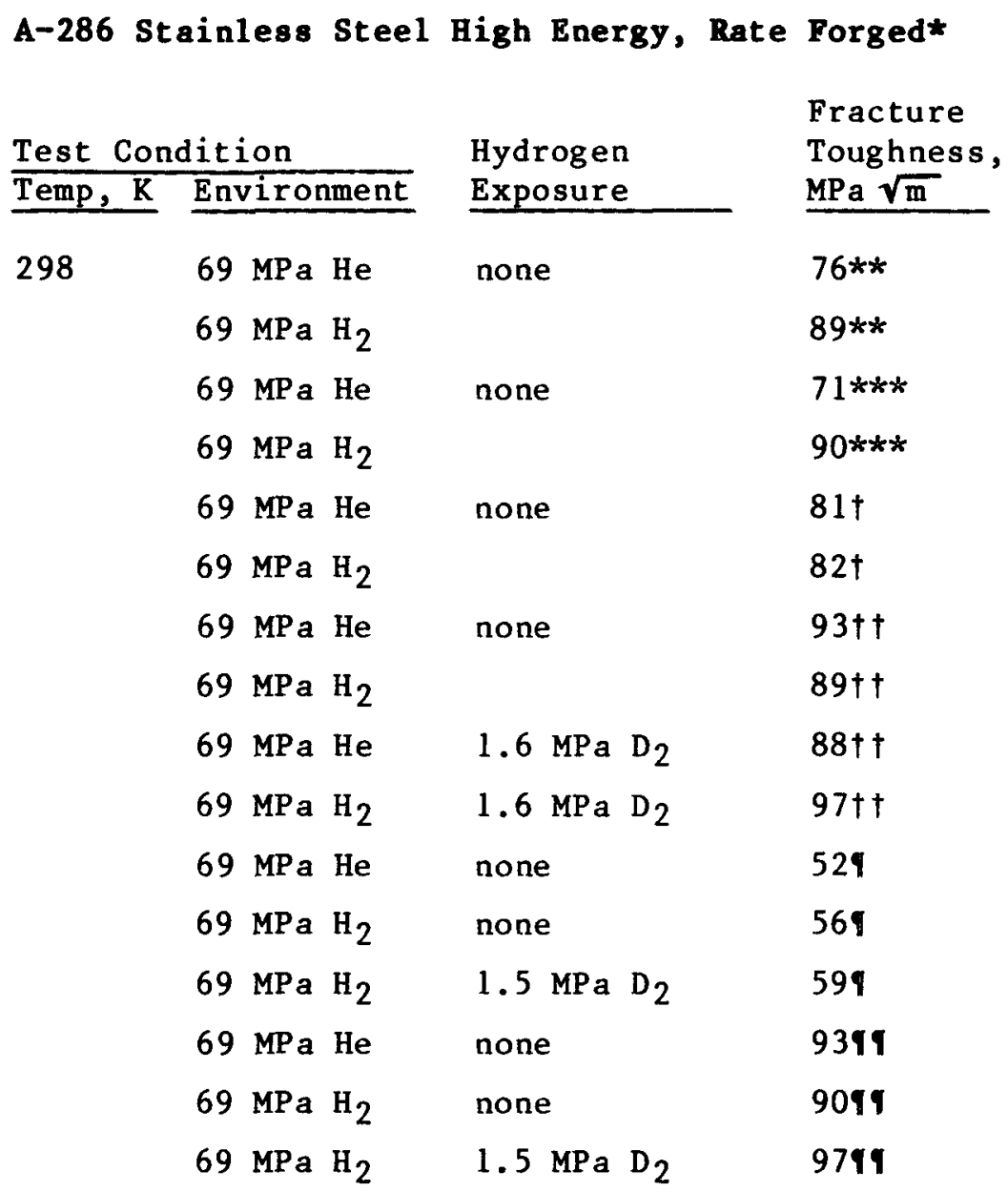

\footnotetext{
* Single edge notched, Appendix C-6.

** Aged 4 hours at $990 \mathrm{~K}$ (Heat 1).

*** Aged 8 hours at $990 \mathrm{~K}$ (Heat 1).

$\dagger$ Aged 16 hours at $990 \mathrm{~K}$ (Heat 1).

t† Aged 8 hours at $990 \mathrm{~K}$ (Heat 2).

I HERF only not aged. $\mathrm{R}_{\mathrm{C}}-11$.

I1 Aged 8 hours at $990 \mathrm{~K}$. $\mathrm{R}_{\mathrm{C}}-11$.
} 
DATA SHEET IIIA-3

A-286 Stainless Steel Notch Impact Test*

Test Condition

Hydrogen Impact

Temp, $\mathrm{K}$ Environment Exposure

Energy, J

298

Air

Base Metal

As Received

6.10

Argon**

5.08

$\mathrm{D} / \mathrm{T} \dagger$

4.74

298

Air

Weld Metal

As Received

4.18

Argon**

3.40

$\mathrm{D} / \mathrm{T} \dagger$

4.51

* Impact Appendix C-8.

** $0.21 \mathrm{MPa}$ at $370 \mathrm{~K}$ for 200 days.

$\dagger 69 \mathrm{MPa} \mathrm{D} / \mathrm{T}$ at $370 \mathrm{~K}$ for 200 days. 
DATA SHEET IIIA-4

Fracture Parameters for A-286 Stainless Stee1*

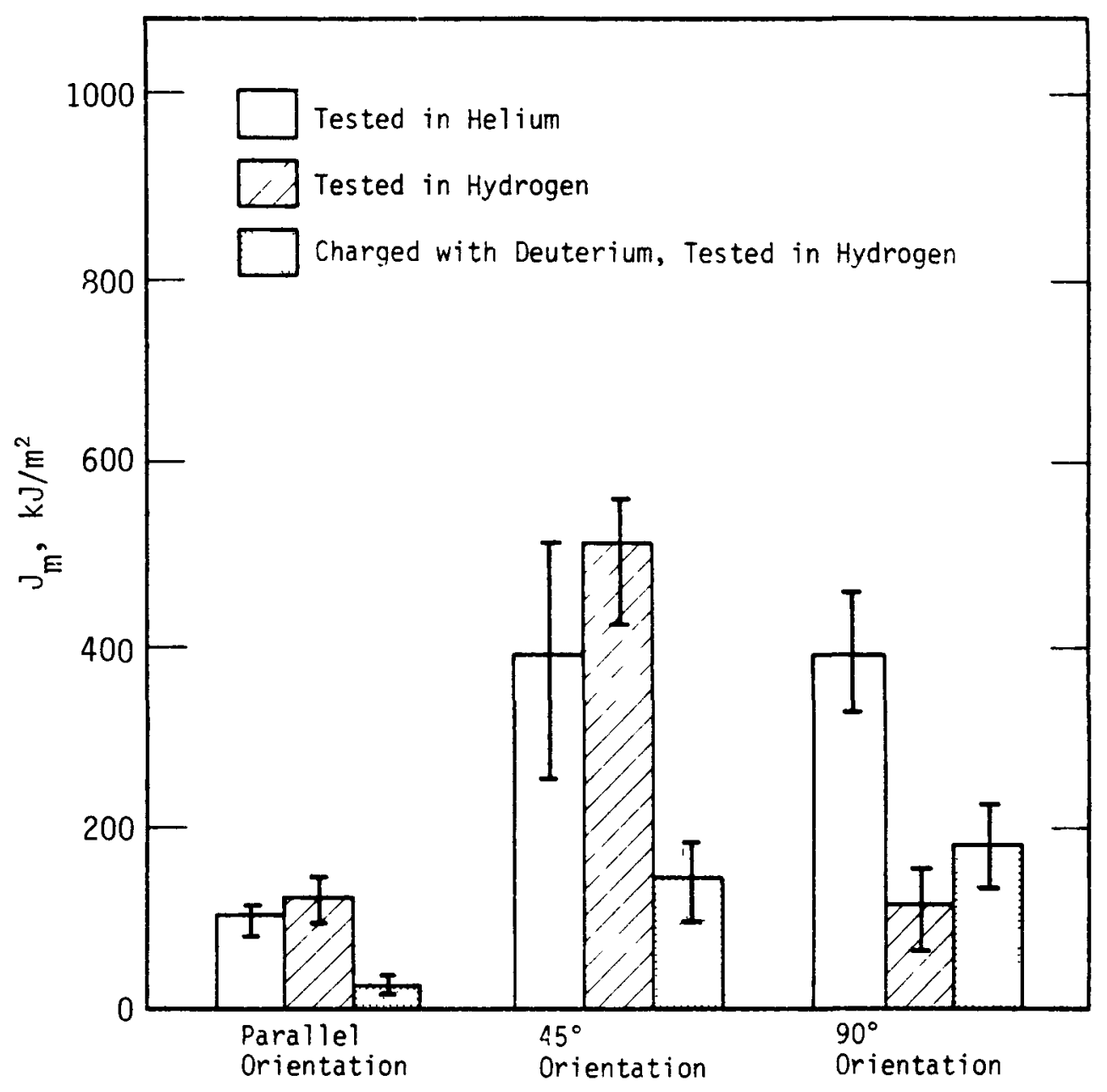

* C-shaped tensile, Appendix C-7. Tested in $69 \mathrm{MPa} \mathrm{H} 2$ or He. Deuterium charged at $69 \mathrm{MPa}$ at $620 \mathrm{~K}$ for 3 weeks. 
DATA SHEET IIIA-5

Fracture Parameters for A-286 Stainless Stee1*

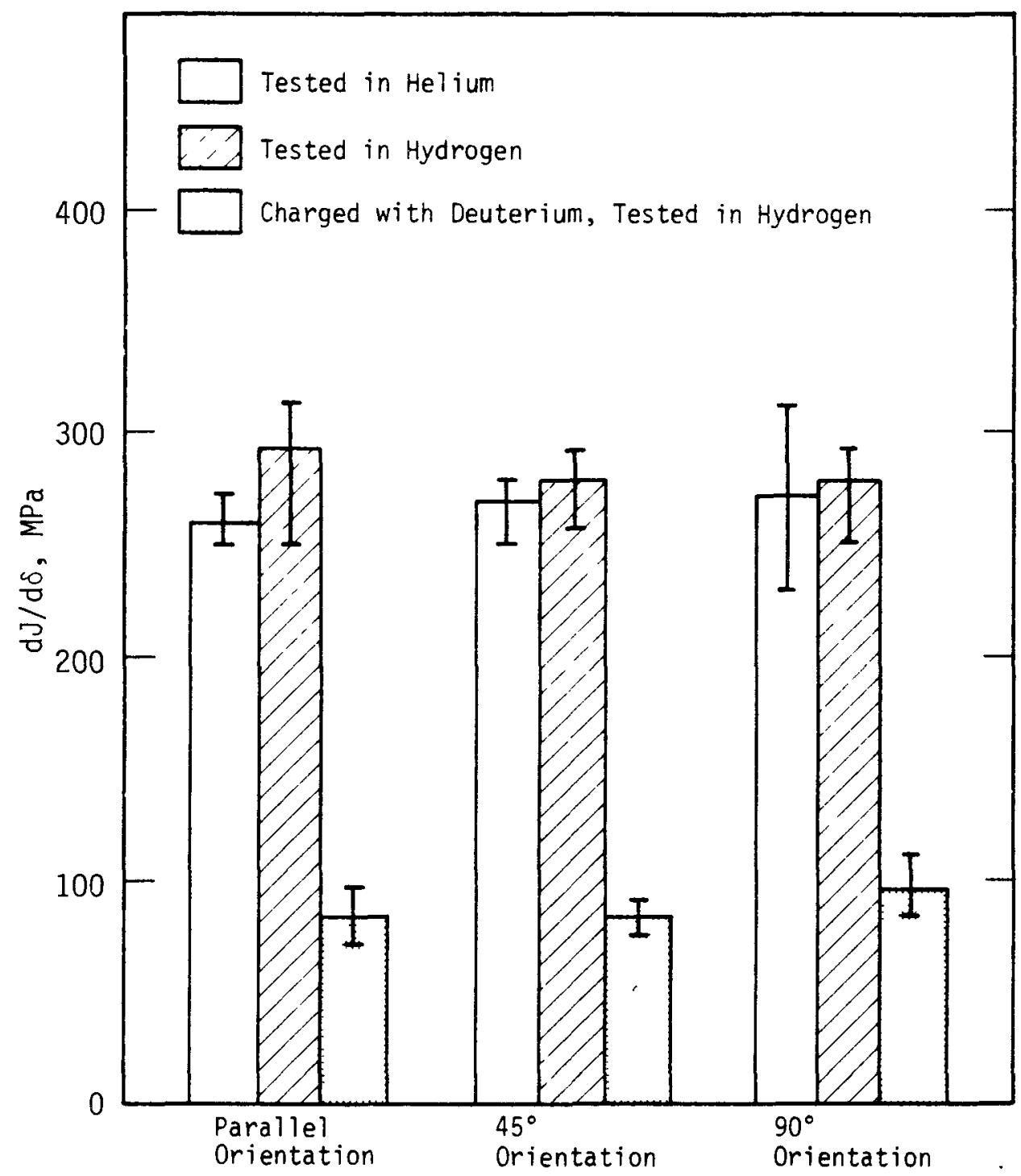

* C-shaped Tensile, Appendix C-7. Tested in $69 \mathrm{MPa} H e$ or $\mathrm{H}_{2}$. Deuterium charged at $69 \mathrm{MPa}$ at $620 \mathrm{~K}$ for 3 weeks. 
DATA SHEET IIIB-1

JBK-75 HERF and Age*

\begin{tabular}{|c|c|c|c|c|c|c|c|}
\hline \multicolumn{2}{|c|}{$\frac{\text { Test Condition }}{\text { Temp, } \mathrm{K} \text { Environment }}$} & \multirow{2}{*}{$\begin{array}{l}\text { Hydrogen } \\
\text { Exposure }\end{array}$} & \multicolumn{2}{|c|}{ Strength, $\mathrm{MPa}$} & \multicolumn{2}{|c|}{ Elongation, \% } & \multirow{2}{*}{$\begin{array}{l}\text { Fracture } \\
\text { Strain } \\
\end{array}$} \\
\hline Temp, $\mathrm{K}$ & Environment & & Yield** & Tensile & Uniform & Total & \\
\hline \multirow[t]{2}{*}{298} & $69 \mathrm{MPa} \mathrm{He}$ & none & 800 & 1090 & 10 & 14 & 0.63 \\
\hline & $69 \mathrm{MPa} \mathrm{H}_{2}$ & none & 890 & 1160 & 10 & 13 & 0.40 \\
\hline
\end{tabular}

* Tensile, Appendix C-3.

$* * 0.2 \%$ offset.

DATA SHEET IIIB-2

JBK-75 HERF and Age*

\begin{tabular}{|c|c|c|c|c|}
\hline \multicolumn{2}{|c|}{$\frac{\text { Test Condition }}{\text { Temp, } \mathrm{K} \text { Environment }}$} & $\begin{array}{l}\text { Hydrogen } \\
\text { Exposure }\end{array}$ & $\begin{array}{l}\text { Stress } \\
\text { Intensity, } \\
\text { MPa } \sqrt{m}\end{array}$ & $\begin{array}{l}\text { Fracture } \\
\text { Energy, } \\
\mathrm{MJ} / \mathrm{m}^{2}\end{array}$ \\
\hline \multirow[t]{3}{*}{298} & $69 \mathrm{MPa} \mathrm{He}$ & none & 80 & 0.350 \\
\hline & $69 \mathrm{MPa} \mathrm{H} 2$ & none & 80 & 0.333 \\
\hline & $69 \mathrm{MPa} \mathrm{H} 2$ & $\begin{array}{l}0.7 \mathrm{MPa} \mathrm{D} \mathrm{D}_{2} \\
\text { at } 625 \mathrm{~K}\end{array}$ & 81 & 0.294 \\
\hline
\end{tabular}

* C-shaped tensile, Appendix C-7. 
DATA SHEET IIIC-1

\begin{tabular}{|c|c|c|c|c|c|c|c|}
\hline \multirow{2}{*}{\multicolumn{2}{|c|}{$\frac{\text { Test Condition }}{\text { Temp, K Environment }}$}} & \multirow{2}{*}{$\begin{array}{l}\text { Hydrogen } \\
\text { Exposure } \\
\end{array}$} & \multirow{2}{*}{$\frac{\text { Strength, }}{\text { Yield** }}$} & \multirow{2}{*}{ MPa } & \multicolumn{2}{|c|}{ Elongation, \% } & \multirow{2}{*}{$\begin{array}{l}\text { Fracture } \\
\text { Strain } \\
\end{array}$} \\
\hline & & & & & Uniform & Total & \\
\hline \multirow[t]{4}{*}{298} & Air & none & 940 & 980 & - & 4.7 & - \\
\hline & $69 \mathrm{MPa} \mathrm{He}$ & $69 \mathrm{MPa} \mathrm{He}$ & 1076 & 1145 & - & 6.4 & - \\
\hline & $35 \mathrm{MPa} \mathrm{D} / \mathrm{T}$ & $35 \mathrm{MPa} \mathrm{D} / \mathrm{T} \dagger$ & 1000 & 1000 & - & 0.7 & - \\
\hline & $69 \mathrm{MPa} \mathrm{D} / \mathrm{T}$ & $69 \mathrm{MPa} \mathrm{D} / \mathrm{T} \dagger \dagger$ & 1062 & 1096 & - & 1.2 & - \\
\hline
\end{tabular}

\footnotetext{
* Tensile E, Appendix C-5.

** $0.2 \%$ offset.

$\dagger 8$ hours at $315 \mathrm{k}$.

$\dagger+2$ hours at $370 \mathrm{~K}$.
}

DATA SHEET IIIC-2

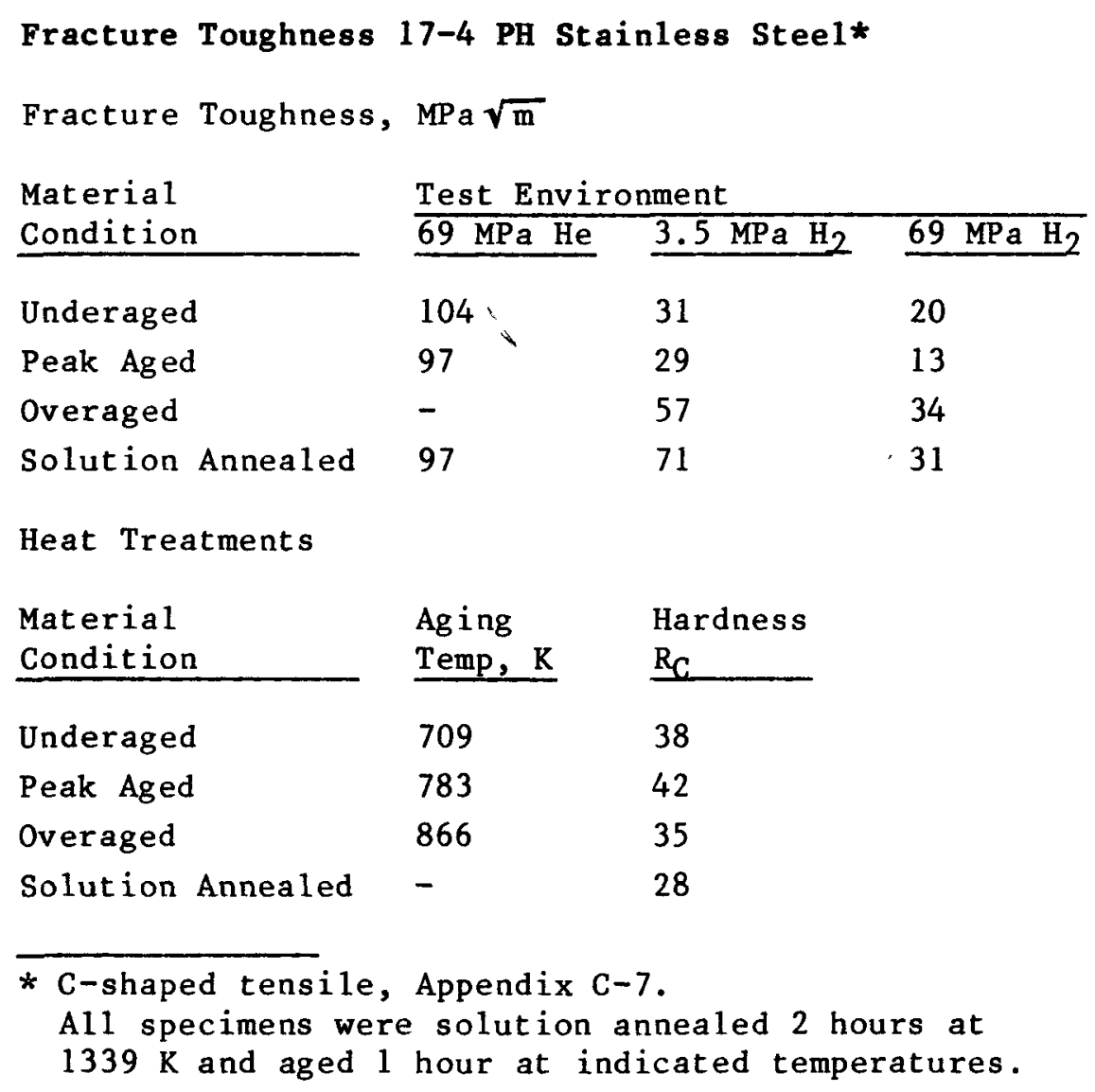


DATA SHEET IIID-1

AM-350 Stainless Steel*

Test Condition

Hydrogen Strength, MPa

Elongation, \% Fracture

Temp, K Environment

Exposure Yield** Tensile

Uniform Total Strain

298

Air

none

420

1160

$-70$

69 MPa†

455

580

$-3 / 4$

$69 \mathrm{MPa} \mathrm{He}$

none

420

1240

$-\quad 55$

$6.9 \mathrm{MPa} \mathrm{D} 2$

none

345

430

$69 \mathrm{MPa} \mathrm{D}_{2}$

none

430

520

$-4$

$0.69 \mathrm{MPa} \mathrm{D}_{2}$

none

410

455

$-\quad 2.6$

- 3

* Condition $\mathrm{H}$ - annealed at 1310 to $1350 \mathrm{~K}$ air cool or water quench.

** $0.2 \%$ offset.

$\dagger 26$ days at $570 \mathrm{~K}$.

DATA SHEET IIIE-1

AM-363 Stainless Steel

Test Condition

Hydrogen

Exposure

298

Air

Air

Air

Air none

$0.21 \mathrm{MPa} \mathrm{H}_{2}$ **

none

$0.21 \mathrm{MPa} \mathrm{H}_{2}^{* *}$
Strength, MPa

Yield* Tensile

890

900

$1340 \dagger$

$1400 \dagger$
890

900

1480

1500 $\begin{array}{ll}\text { Elongation, } \% & \text { Fracture } \\ \text { Uniform Total } & \text { Strain }\end{array}$

Uniform Total strain

- 7 -

$-8.6-$

- 3

- 3

* $0.21 \mathrm{MPa} \mathrm{D}_{2}$ at $630 \mathrm{~K}$ for 5 days.

** $0.2 \%$ offset.

$\dagger$ Notched $-45^{\circ}$ notch. Notch diameter $=0.5 \mathrm{X}$ outer diameter. 


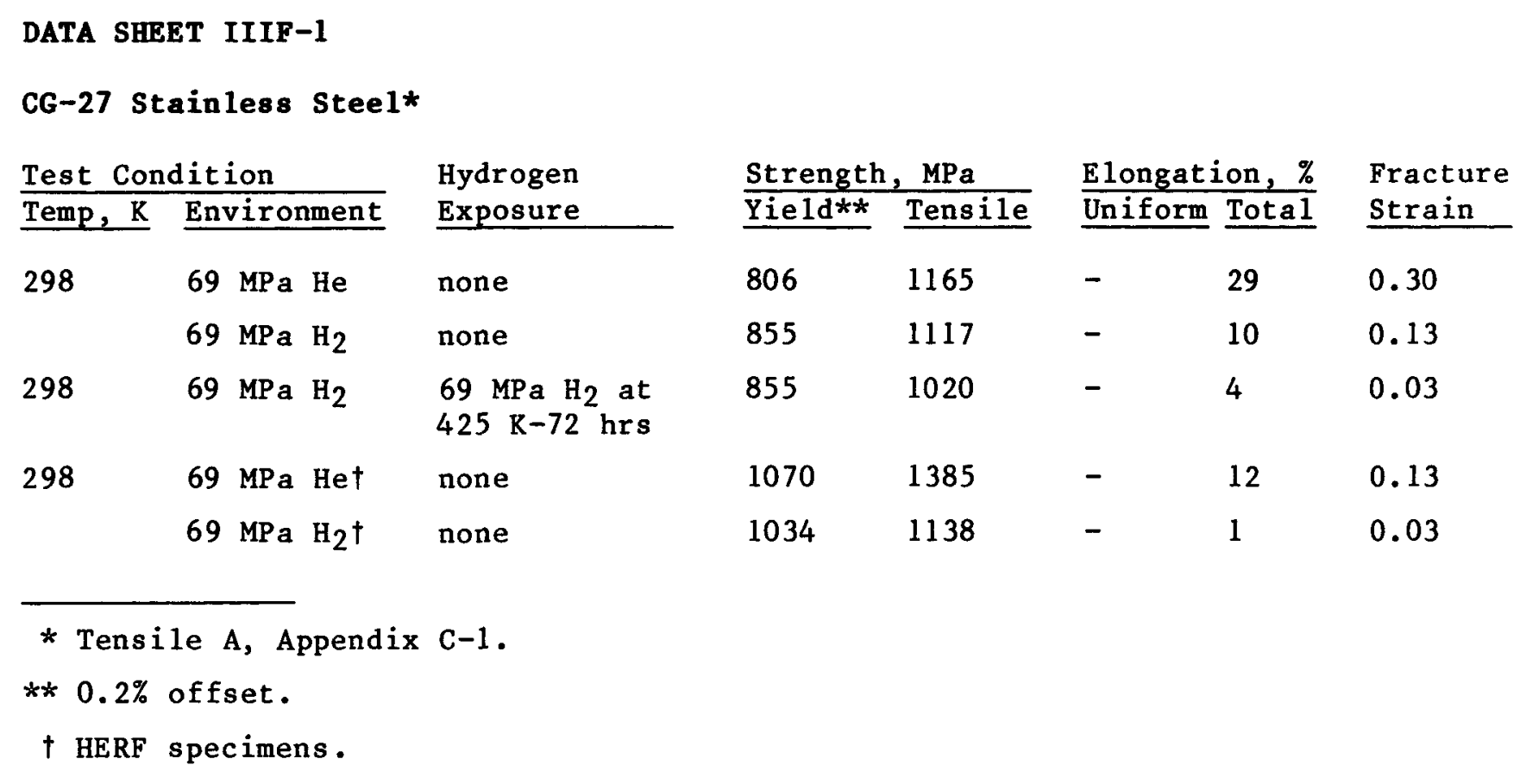

DATA SHEET IIIG-1

Ni-SPAN-C* (A1loy 902)

Test Condition Temp, K Environment 298
Hydrogen Exposure

none

none

none

none
Strength, MPa $\underline{\text { Yield }}{ }^{* *}$ Tensile 676

750

-

650
1186

1160

1170

1130
Elongation, \% Fracture Uniform Total Strain

- $10 \quad-$

- 16 -

- 14 -

- 15

* Sheet specimens $0.25 \mathrm{~mm}$ and $19 \mathrm{~mm}$ gauge length. ** $0.2 \%$ offset. 
HIGH PURITY ALLOYS

DATA SHEET IVA-1

Mechanical Properties (Alloy A)*

\begin{tabular}{|c|c|c|c|c|c|c|c|}
\hline \multicolumn{2}{|c|}{ Test Condition } & \multirow{2}{*}{$\begin{array}{l}\text { Hydrogen } \\
\text { Exposure**}\end{array}$} & \multicolumn{2}{|c|}{ Strength, MPa } & \multicolumn{2}{|c|}{ Elongation, \% } & \multirow{2}{*}{$\begin{array}{l}\text { Fracture } \\
\text { Strain }\end{array}$} \\
\hline Temp, $\mathrm{K}$ & Environment & & Yield & U1timate & Uniform & Total & \\
\hline 370 & Air & $\begin{array}{l}\text { none } \\
69 \mathrm{MPa}\end{array}$ & $\begin{array}{l}230 \\
270\end{array}$ & $\begin{array}{l}610 \\
660\end{array}$ & $\begin{array}{l}45 \\
50\end{array}$ & $\begin{array}{l}52 \\
59\end{array}$ & $\begin{array}{l}1.57 \\
1.65\end{array}$ \\
\hline 298 & Air & $\begin{array}{l}\text { none } \\
69 \mathrm{MPa}\end{array}$ & $\begin{array}{l}350 \\
290\end{array}$ & $\begin{array}{l}1270 \\
1030\end{array}$ & $\begin{array}{l}62 \\
60\end{array}$ & $\begin{array}{l}73 \\
60\end{array}$ & $\begin{array}{l}1.66 \\
0.50\end{array}$ \\
\hline 235 & $\operatorname{Air}$ & $69 \mathrm{MPa}$ & 390 & 1110 & 38 & 38 & 0.27 \\
\hline 200 & Air & $\begin{array}{l}\text { none } \\
69 \mathrm{MPa}\end{array}$ & $\begin{array}{l}540 \\
420\end{array}$ & $\begin{array}{l}1320 \\
1190\end{array}$ & $\begin{array}{l}36 \\
33\end{array}$ & $\begin{array}{l}46 \\
33\end{array}$ & $\begin{array}{l}1.42 \\
0.31\end{array}$ \\
\hline 78 & LN & $\begin{array}{l}\text { none } \\
69 \mathrm{MPa}\end{array}$ & $\begin{array}{l}- \\
-\end{array}$ & $\overline{1060}$ & $\overline{42}$ & - & $\begin{array}{l}1.44 \\
1.13\end{array}$ \\
\hline
\end{tabular}

* Tensile B, Appendix $\mathrm{C}-2$.

** Exposed at $620 \mathrm{~K}$ for 3 weeks. 
DATA SHEET IVB-1

\begin{tabular}{|c|c|c|c|c|c|c|c|}
\hline \multirow{2}{*}{\multicolumn{2}{|c|}{$\begin{array}{l}\text { Test Condition } \\
\text { Temp, K Environment }\end{array}$}} & \multirow{2}{*}{$\begin{array}{l}\text { Hydrogen } \\
\text { Exposure** }\end{array}$} & \multicolumn{2}{|c|}{ Strength, $\mathrm{MPa}$} & \multirow{2}{*}{\multicolumn{2}{|c|}{$\frac{\text { Elongation, } \%}{\text { Uniform Total }}$}} & \multirow{2}{*}{$\begin{array}{l}\text { Fracture } \\
\text { Strain } \\
\end{array}$} \\
\hline & & & Yield & U1timate & & & \\
\hline 370 & Air & $\begin{array}{l}\text { none } \\
69 \mathrm{MPa}\end{array}$ & $\begin{array}{l}240 \\
260\end{array}$ & $\begin{array}{l}630 \\
660\end{array}$ & $\begin{array}{l}45 \\
46\end{array}$ & $\begin{array}{l}56 \\
56\end{array}$ & $\begin{array}{l}1.58 \\
1.40\end{array}$ \\
\hline 298 & Air & $\begin{array}{l}\text { none } \\
69 \mathrm{MPa}\end{array}$ & $\begin{array}{l}340 \\
290\end{array}$ & $\begin{array}{l}1020 \\
870\end{array}$ & $\begin{array}{l}61 \\
65\end{array}$ & $\begin{array}{l}69 \\
72\end{array}$ & $\begin{array}{l}1.56 \\
1.50\end{array}$ \\
\hline 235 & Air & $69 \mathrm{MPa}$ & 320 & 1170 & 72 & 79 & 0.44 \\
\hline 200 & Air & $\begin{array}{l}\text { none } \\
69 \mathrm{MPa}\end{array}$ & $\begin{array}{l}340 \\
380\end{array}$ & $\begin{array}{l}1170 \\
1250\end{array}$ & $\begin{array}{l}64 \\
66\end{array}$ & $\begin{array}{l}74 \\
71\end{array}$ & $\begin{array}{l}1.57 \\
0.89\end{array}$ \\
\hline 78 & LN & $\begin{array}{l}\text { none } \\
69 \mathrm{MPa}\end{array}$ & $\begin{array}{l}260 \\
270\end{array}$ & $\begin{array}{l}870 \\
900\end{array}$ & $\begin{array}{l}63 \\
66\end{array}$ & $\begin{array}{l}67 \\
72\end{array}$ & $\begin{array}{l}1.37 \\
1.41\end{array}$ \\
\hline
\end{tabular}

* Tensile B, Appendix C-2.

** Exposed at $620 \mathrm{~K}$ for 3 weeks.

DATA SHEET IVC-1

Mechanical Properties (Alloy C)*

\begin{tabular}{|c|c|c|c|c|c|c|c|}
\hline Test Con & & Hydrogen & Streng & $\mathrm{h}, \mathrm{MPa}$ & E1ongati & on, $\%$ & Fracture \\
\hline Temp, $\mathrm{K}$ & Environment & Exposure** & Yie1d & U1timate & Uniform & Total & Strain \\
\hline 370 & Air & $\begin{array}{l}\text { none } \\
69 \mathrm{MPa}\end{array}$ & $\begin{array}{l}250 \\
260\end{array}$ & $\begin{array}{l}630 \\
660\end{array}$ & $\begin{array}{l}44 \\
45\end{array}$ & $\begin{array}{l}52 \\
53\end{array}$ & $\begin{array}{l}1.62 \\
1.45\end{array}$ \\
\hline 298 & Air & $\begin{array}{l}\text { none } \\
69 \mathrm{MPa}\end{array}$ & $\begin{array}{l}330 \\
290\end{array}$ & $\begin{array}{l}910 \\
770\end{array}$ & $\begin{array}{l}49 \\
52\end{array}$ & $\begin{array}{l}58 \\
62\end{array}$ & $\begin{array}{l}1.65 \\
1.55\end{array}$ \\
\hline 200 & Air & $\begin{array}{l}\text { none } \\
69 \mathrm{MPa}\end{array}$ & $\begin{array}{l}300 \\
330\end{array}$ & $\begin{array}{l}1100 \\
1170\end{array}$ & $\begin{array}{l}78 \\
78\end{array}$ & $\begin{array}{l}87 \\
86\end{array}$ & $\begin{array}{l}1.52 \\
1.50\end{array}$ \\
\hline 78 & LN & $\begin{array}{l}\text { none } \\
69 \mathrm{MPa}\end{array}$ & $\begin{array}{l}250 \\
280\end{array}$ & $\begin{array}{l}850 \\
890\end{array}$ & $\begin{array}{l}82 \\
80\end{array}$ & $\begin{array}{l}89 \\
86\end{array}$ & $\begin{array}{l}1.53 \\
1.43\end{array}$ \\
\hline
\end{tabular}

* Tensile B, Appendix C-2.

** Exposed at $620 \mathrm{~K}$ for 3 weeks. 
1. I. M. Bernstein and A. W. Thompson. Hydrogen in Metals, ed., American Society for Metals, Metals Park, Ohio (1974).

2. A. W. Thompson and I. M. Bernstein. Effect of Hydrogen on Behavior of Materials, ed., Metallurgical Society of AIME, New York, NY (1976).

3. A. W. Thompson and I. M. Bernstein. Effect of Hydrogen on Behavior of Materials, ed., Metallurgical Society of AIME, Warrendale, PA (1981).

4. M. R. Louthan, Jr. and R. P. McNitt. Environmental Degradation of Engineering Materials, ed., Virginia Polytechnic Institute, Blacksburg, VA (1977).

5. M. R. Louthan, Jr., R. P. McNitt, and R. D. Sisson, Jr. Environmental Degradation of Engineering Materials - II, ed., Virginia Polytechnic Institute, Blacksburg, VA (1981).

6. MM J. P. Fidelle et. M. Papin. L'Hydrogen Dans Les Metaux, Co11oque - Valduc (27-28, September 1967).

7. "L'Hydrogen Dans Les Metaux-2." Congress International, Paris (29 Mai-2 Juin, 1972).

8. "Hydrogen in Metals." Proceedings of the 2nd International Congress, Paris, 6-10 June 1977. Pergamon Press, New York, (1977).

9. "Hydrogen in Metals," Proceedings of the 3rd International Congress, Paris, 7-2 June 1982.

10. "Hydrogen Embritt lement Testing." ASTM Special Technical Publication 543, American Society for Testing and Materials, Philadelphia, PA (1974).

11. Advanced Techniques for Characterizing Hydrogen in Metals, TMS-AIME, Warrendale, PA (1982).

12. C. D. Beachem, ed. Hydrogen Damage, American Society for Metals, Metals Park, OH (1979). 
13. J. P. Hirth and H. H. Johnson. "Hydrogen Problems in Energy Related Technology." Corrosion 32, 3 (1976).

14. J. J. Au and H. K. Birnbaum. "Hydrogen Effects on the Deformation of Iron Whiskers." Scripta Met 12, 457 (1978).

15. G. C. Smith. "Effect of Hydrogen on Nickel and Nicke1-Base Alloys." Hydrogen in Metals. p. 485, American Society for Metals, Metals Park, Ohio (1974).

16. J. K. Tien, A. W. Thompson, I. M. Bernstein, and Rebecca J. Richards. "Hydrogen Transport by Dislocations." Met. Trans. 7A, $821(1976)$.

17. A. W. Thompson, "The Mechanism of Hydrogen Participation in Ductile Fracture." Effect of Hydrogen on Behavior of Materials. p. 467, Metallurgical Society of AIME, Warrendale, PA (1976).

18. J. F. Breedis and L. Kaufmann. "Formation of HCP and BCC Phases in Austenitic Iron Alloys." Met. Trans. 2, 2359 (1971).

19. D. V. Neff, T. E. Mitchell, and A. R. Troiano. "The Influence of Temperature, Transformation, and Strain-Rate on the Ductility Properties of Austenitic Stainless Steels." Trans. ASM 62, 858 (1969).

20. B. C. Odegard, J. A. Brooks, and A. J. West. "The Effect of Hydrogen on the Mechanical Behavior of Nitrogen Strengthened Stainless Stee1." p. 116 in Effect of Hydrogen on Behavior of Materials. Metallurical Society of AIME, Warrendale, PA (1976).

21. R. E. Stoltz and J. B. Vander Sande. "The Effect of Nitrogen on Stacking Fault Energy of Fe-Cr-Ni-Mn Steels." Met. Trans. $11 \mathrm{~A}, 1033$ (1980).

22. H. Mecking. "Deformation of Polycrystals." p. 1573 in Strength of Metals and Alloys, Vol. 3, Pergamon Press, New York (1980).

23. C. L. Briant. "Hydrogen Assisted Cracking of Sensitized 304 Stainless Steel." Met. Sci. 9A, 731 (1978).

24. A. W. Thompson. "The Behavior of Sensitized 309S Stainless Steel in Hydrogen." Mat. Sci. and Eng. 14, 253 (1974).

25. J. D. Hobson and J. Hewitt. "The Effect of Hydrogen on the Tensile Properties of Steel." Journal Iron and Steel Institute 172, 131 (1953). 
26. H. R. Gray. "Testing for Hydrogen Environment Embrittlement: Experimental Variables." p. 133 in Hydrogen Embrittlement Testing. ASTM STP 543, American Society for Testing and Materials, Philadelphia, PA (1974).

27. M. B. Whiteman and A. R. Troiano. "Hydrogen Embrittlement of Austenitic Stainless Steels." Corrosion 21, 53 (1965).

28. J. P. Fidelle, et al. "Disk Pressure Testing of Hydrogen Environment Embrittlement." p. 221 in Hydrogen Embrittlement Testing. ASTM STP 543, American Society for Testing and Materials, Philadelphia, PA (1974).

29. D. Eliezer, D. G. Chakrapani, C. J. Alstetter, and E. N. Pugh. "The Influence of Austenite Stability on the Hydrogen Embrittlement and Stress Corrosion Cracking of Stainless Steel." Met. Trans. 10A, 935 (1979).

30. D. Eliezer. Hydrogen Assisted Cracking in Type $304 \mathrm{~L}$ and $316 \mathrm{~L}$ Stainless Steel. Third International Conference on Effect of Hydrogen on Behavior of Materials, August 1980.

31. R. J. Walter and W. T. Chandler, P. 104 discussion to paper by A. W. Thompson. "Ductility Losses in Stainless Steel." Hydrogen in Metals. American Society for Metals, Metals Park, Ohio (1974).

32. M. W. Perra. "Sustained-Load Cracking of Austenitic Steels in Gaseous Hydrogen." Environmental Degradation of Engineering Materials. ed., M. R. Louthan, Jr, R. P. McNitt, and R. D. Sisson, Jr., VPI, Blacksburg, VA 321-333 (1981).

33. A. W. Loginow and E. H. Phelps "Steels for Seamless Hydrogen Pressure Vessels" Corrosion 31404 (1975).

34. R. L. Tobler and R. P. Reed. "Tensile and Fracture Behavior of a Nitrogen Strengthened Chromium-Nicke1-Manganese Stainless Steel at Cryogenic Temperatures", p. 537 in Special Technical Publication, ASTM STP 668. American Society for Testing and Materials, Philadelphia, PA (1979).

35. R. L. Tobler, D. T. Read, and R. P. Reed. "Strength/Toughness Relationship for Interstitially Strengthened AISI 304 Stainless Stee 1 at $4 \mathrm{~K}$ Temperature," p. 250 in Special Technical Publication ASTM STP 743, American Society for Testing and Materials, Philadelphia, PA (1982).

36. W. Losch and I. Andreoni. "Grain Boundary Surface Phases Observed in Temper Embrittled High-Alloy Steels." Scripta Met. 12, 277 (1978). 
37. A. W. Thompson. "Mechanical Behavior of Face-Centered Cubic Metals Containing Helium." Mater. Sci. and Eng. 21, 41-48 (1975).

38. M. R. Louthan, Jr., G. R. Caskey, D. E. Raw1, Jr., and C. W. Krapp. "Tritium Effects in Austenitic Steels." p. 117 in Proceedings of International Conference on Radiation Effects and Tritium Technology for Fusion Reactors IV. CONF-752026-13 (1976).

39. D. E. Rawl, Jr., G. R. Caskey, Jr., and J. A. Donovan. "Low Temperature Helium Embrittlement of Tritium Charged Stainless Steel." 109th Annual AIME Meeting, Las Vegas, Nevada, February $24-28,1980$.

40. J. A. Donovan. "Effects of Helium on Mechanical Properties of Armco Iron." Fall TMS-AIME Meeting, Niagara Fa11s, New York, September 20-23, 1976.

41. A. J. West and D. E. Rawl, Jr. "Hydrogen in Stainless Steel: Isotopic Effects on Mechanical Properties." Proceedings of Conference in Tritium Technology in Fusion, Fusion and Isotopic Applications. Conference 800427 (1980).

42. M. R. Louthan and R. G. Derrick, "Hydrogen Transport in Austenitic Stainless Steel." Corros. Sci. 15 565 (1975).

43. G. R. Caskey, Jr., and R. D. Sisson, Jr. "Hydrogen Solubility in Austenitic Stainless Steel." Scripta Met 15, 1187 (1981).

44. M. R. Dietrich, G. R. Caskey, Jr., and J. A. Donovan. J-Controlled Crack Growth as an Indicator of Hydrogen-Stainless Steel Compatibility, Hydrogen Effects in Metals, ed. I. M. Bernstein and A. W. Thompson, Metallurgical Society of AIME, Warrendale, PA, p. 637 (1981).

45. G. R. Caskey, Jr., D. A. Mezzanotte, Jr., and D. E. Rawl, Jr. "Helium Embrittlement Stainless Steels at Ambient Temperature." Scripta Met 16,969 (1982).

46. T. L. Capeletti and M. R. Louthan, Jr. "The Tensile Ductility of Austenitic Steels in Air and Hydrogen." Journal of Engineering Materials and Technology, 99, 153-158 (1977).

47. T. L. Capeletti. "Effect of Hydrogen Exposure or the Fracture Toughness of 17-4 pH Stainless Steel." Int. Conference on Mechanical Behavior of Materials, Boston, August 16-20 (1976). Conference 760819-12. 
48. G. R. Caskey, Jr. "The Role of Twinning and Transformation in Hydrogen Embrittlement of Austenitic Stainless Steels" in Environmental Degradation of Engineering Materials, ed. by M. R. Louthan and R. P. McNitt, Virginia Polytechnic Institute, Blacksburg, VA, Pp. 437-449 (1977).

49. G. R. Caskey, Jr. "Fractography of Hydrogen Embrittled Stainless Steel." Scripta Met 11, 1077-1083 (1977).

50. G. R. Caskey, Jr. "A Mechanism for Hydrogen-Induced Brittle Fracture of Austenitic Stainless Stee1." DP-MS-77-86, E. I. du Pont de Nemours \& Co., Savannah River Laboratory, Aiken, SC, 107th Annual AIME Meeting, Denver, CO, February 26 March 2, 1978.

51. G. R. Caskey, Jr. "Fracture of Fe-Cr-Mn Austenitic Steel." DP-MS-78-68, E. I. du Pont de Nemours \& Co., Savannah River Laboratory, Aiken, SC, 108th Annual AIME Meeting, New Orleans, LA, February 18-20, 1979.

52. G. R. Caskey, Jr. and J. A. Donovan. "Effect of Heat Treatment on Fracture of Type 304L Stainless Stee1 in a Hydrogen Environment." DP-MS-79-18, E. I. du Pont de Nemours \& Co., Savannah River Laboratory, Aiken, SC, 1979, TMS-AIME Fal1 Meeting, Milwaukee, WI, September 16-20, 1979.

53. G. R. Caskey, Jr. "Notch and Hydrogen Effects on Sensitized 21-6-9 Stainless Steel." DP-MS-79-22, E. I. du Pont de Nemours \& Co., Savannah River Laboratory, Aiken, SC, 1979 TMS-AIME Fal1 Meeting, Milwaukee, WI, September 16-20, 1979.

54. G. R. Caskey, Jr. "Hydrogen Effects on Flow Localization and Fracture in Type 304L Stainless Steel." DP-MS-79-57, E. I. du Pont de Nemours \& Co., Savannah River Laboratory, Aiken, SC, Gordon Research Conference, Andover, NH, July 9-13, 1979.

55. G. R. Caskey, Jr. "Acoustic Emission from Hydrogen Saturated Type 304L Stainless Steel." Scripta Met 13 583-587 (1979).

56. G. R. Caskey, Jr. "Hydrogen Assisted Fracture of Sensitized Type 304L Austenitic Stainless Steel." DP-MS-79-62, E. I. du Pont de Nemours \& Co., Savannah River Laboratory, Aiken, SC, 109th Annual AIME Meeting, Las Vegas, NV, February $24-28,1980$.

57. G. R. Caskey, Jr. "Fractography of Hydrogen-Embrittled Iron Chromium-Nickel Alloys." Microstructural Science 9, 413-419 (1981). 
58. G. R. Caskey, Jr. "Hydrogen Induced Brittle Fracture of Type 304L Austenitic Stainless Stee1." American Society for Testing and Materials, STP 733, 86-97 (1981).

59. G. R. Caskey, Jr. "Effect of Hydrogen on Work Hardening of Type 304L Austenitic Stainless Steel." Scripta Met 15, 1183-1186 (1981).

60. G. R. Caskey, Jr. "Hydrogen Damage in Stainless Stee1." Environmental Degradation of Engineering Materials. Edited by M. R. Louthan, Jr., R. P. McNitt, and R. D. Sisson, Virginia Polytechnic Institute, Blacksburg, VA, pp. 283-302 (1981).

61. G. R. Caskey, Jr. "Hydrogen Effects in High Purity Stainless Steels." Third International Congress on Hydrogen and Materials, Paris, France, June 7-11, 1982.

62. J. A. Donovan. "Accelerated Evolution of Hydrogen from Metals During Plastic Deformation." Met. Trans. 7A, 1677-1683 (1977).

63. M. L. Holzworth and M. R. Louthan, Jr. "Hydrogen Induced Phase Transformations on Type 304L Stainless Steels." Corrosion 24, 110-124 (1968).

64. M. L. Holzworth. "Hydrogen Embrittlement of Type 304L Stainless Steel." Corrosion 25, 107-115 (1969).

65. M. R. Louthan, Jr., G. R. Caskey, Jr., J. A. Donovan, and D. E. Rawl, Jr. "Hydrogen Embrittlement of Metals." Mater. Sci. and Eng. 10357 (1972).

66. M. R. Louthan, Jr., J. A. Donovan, and D. E. Raw1, Jr. "Effect of High Dislocation Density on Stress Corrosion Cracking and Hydrogen Embrittlement of Type 304L Stainless Steel." Corrosion 29, 108-111 (1973).

67. M. R. Louthan, Jr., J. A. Donovan, and G. R. Caskey, Jr. "Tritium Absorption in Type 304L Stainless Steel." Nuclear Technology 26, 192-200 (1975).

68. M. R. Louthan, Jr., D. E. Rawl, Jr., J. A. Donovan, and W. G. Holmes. "Hydrogen Embrittlement of Austenitic Stainless Stee1s." Trans. Am. Nuc. Soc. 21, 158 (1975).

69. M. R. Louthan, Jr. and G. R. Caskey, Jr. "Hydrogen Transport and Embrittlement in Structural Metals." 1st World Hydrogen Energy Conference (1976). 
70. M. R. Louthan, Jr. and R. P. McNitt. "The Role of Test Technique in Evaluating Hydrogen Embrittlement Mechanism." Effect of Hydrogen in Behavior of Materials, ed. A. W. Thompson and I. M. Bernstein, Metallurgical Society of AIME, Warrendale, PA, p. 496 (1976).

71. M. R. Louthan, Jr. "Effect of Hydrogen on the Mechanical Properties of Low Carbon and Austenitic Steels." Hydrogen in Metals, ed. T. M. Bernstein and A. W. Thompson, American Society for Metals, Metals Park, Ohio, pp. 53-77 (1974). 
APPENDIX A. DEFINITIONS

\section{ELONGATION}

Percentage increase of a gauge length, usually one inch, during plastic strain in tension. In the data presented here, crosshead motion was taken as the measure of change in length.

Total elongation is length increase at fracture.

Uniform elongation is length increase to the point where drop in load is detected which signals beginning of observable strain localization or necking.

\section{HEAT TREATMENTS}

Aging is a process of heating a previously solution-treated alloy to an intermediate temperature to cause precipitation of a finely dispersed phase which hardens the alloy.

Sensitization is a heat treatment that causes precipitation of carbides of the form $\mathrm{M}_{23} \mathrm{C}_{6}$ along grain boundaries and simultaneously reduces the chromium content of the grain boundary regions.

Solution annealing is a process of heating to elevated temperature to dissolve all precipitates and produce a homogeneous solid solution and quenching to retain the solid solution.

\section{MECHANICAL PROCESSING}

Ingots of stainless steel are formed into plate or bar by mechanical processes of rolling and forging.

Cross-rolled plate refers to turning plate $90^{\circ}$ between passes through the rolling mills to minimize preferred orientation that arises during the rolling process.

High energy rate forged (HERF) alloys are hot forged at a very rapid rate and immediately quenched in water to retain deformation introduced during forging. 


\section{PLASTIC STRAIN}

Irreversible or permanent strain of the test specimen measured by subtracting elastic or recoverable strain from total strain. This was usually done graphically on the load-deformation record obtained during a tensile test.

Plastic strain to failure $(p)$ is calculated from the measured change in cross sectional area from the original ( $A_{0}$ ) to the final area $\left(A_{f}\right)$ at the fracture.

$$
\varepsilon_{p}=\ln A_{0} / A_{f}
$$

Reduction in area ( $R A$ ) is a measure of plasticity calculated from the original $\left(A_{0}\right)$ and final $\left(A_{f}\right)$ cross sectional areas.

$$
R A=100 \frac{A_{0}-A_{f}}{A_{0}}
$$

\section{STRESS}

Stress or force per unit area may be defined with respect to an initial area (engineering stress) or the instantaneous area (true stress). Both definitions have been utilized in data presented here and are distinguished in each table.

Yield strength is the stress corresponding to a plastic strain of $5 \%$ unless otherwise noted. load.

U1timate strength is the true stress corresponding at maximum

Tensile strength is the engineering stress at maximum load.

\section{STRESS INTENSITY}

The stress intensity factor $(K)$ relates the stress field $\left(\sigma_{i j}\right)$ around a crack tip to the crack dimensions (a) and specimen dimensions (width $=w$ ), where the function $f(a, w)$ depends on specimen shape, crack location and loading mode.

The stress intensity corresponding to the critical value for crack extension is the Fracture Toughness $\left(\mathrm{K}_{\mathrm{c}}\right)$. Fracture toughness is a measure of the ability of a material to resist crack propagation.

Under sustained load, cracks will propagate in hydrogen at stress intensities greater than a threshold or $\mathrm{K}_{\mathrm{TH}}$ • 


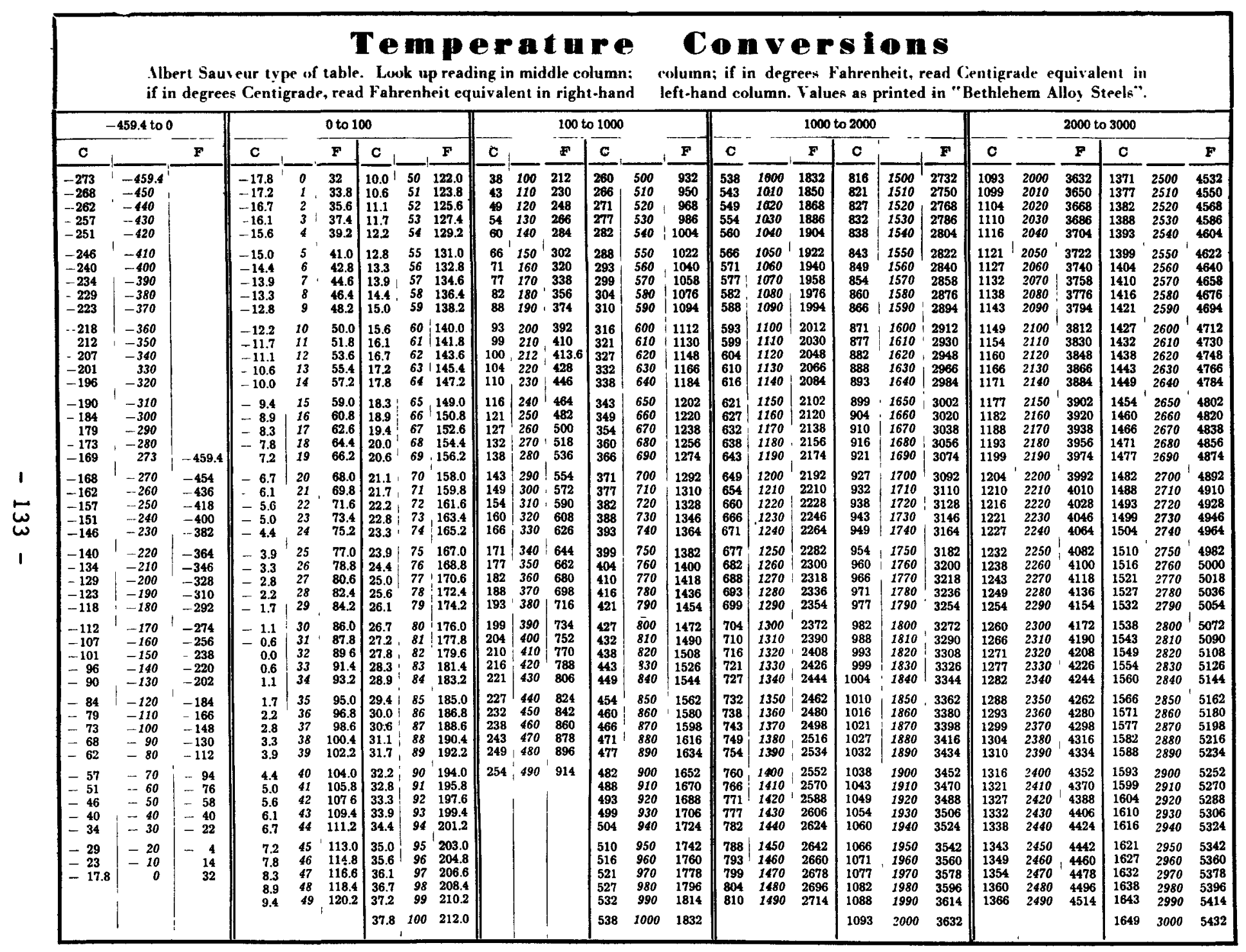

Reproduced from METAL PROGRESS DATA SHEET No. 18 (1954) by permission from American Society for Metals, Metals Park, Ohio 44073. 


\section{English/Metric(SI) Stress Conversion Factors}

Loo' up stress to be converted in the boldface column if in ksı (103 psi), read MPa in right hand column if in $\mathrm{MPa}$ read $\mathrm{ksi}$ in lefthand column Conversion factors $1 \mathrm{MPa} \quad 1 \mathrm{MN} / \mathrm{m}^{2}$ (meganewton per square metre) or $1 \mathrm{~N} \mathrm{mm²}$ (newton per square millımetre) $1 \mathrm{MPa} \quad 01450377$ ksl and 1 ksi 6894759 MPa

\begin{tabular}{|c|c|c|c|c|c|c|c|c|c|c|c|}
\hline \multirow[b]{2}{*}{ ksi } & \multicolumn{3}{|c|}{0 to 100} & & & \multicolumn{6}{|c|}{100 to 200} \\
\hline & & $\mathrm{MPa}$ & ksı & & $\mathrm{MPa}$ & ksı & & $\mathrm{MPa}$ & ksı & & $\mathrm{MPa}$ \\
\hline $\begin{array}{l}\quad- \\
015 \\
029 \\
044 \\
058\end{array}$ & $\begin{array}{l}0 \\
1 \\
2 \\
3 \\
4\end{array}$ & $\begin{array}{r}- \\
689 \\
1379 \\
2068 \\
2757\end{array}$ & $\begin{array}{l}725 \\
740 \\
754 \\
769 \\
783\end{array}$ & $\begin{array}{l}50 \\
51 \\
52 \\
53 \\
54\end{array}$ & $\begin{array}{l}3447 \\
3516 \\
3585 \\
3654 \\
3723\end{array}$ & $\begin{array}{l}1450 \\
1465 \\
1479 \\
1494 \\
1508\end{array}$ & $\begin{array}{l}100 \\
101 \\
102 \\
103 \\
104\end{array}$ & $\begin{array}{l}6895 \\
6964 \\
7033 \\
7102 \\
7171\end{array}$ & $\begin{array}{lll}21 & 76 \\
21 & 90 \\
22 & 05 \\
22 & 19 \\
22 & 34\end{array}$ & $\begin{array}{l}150 \\
151 \\
152 \\
153 \\
154\end{array}$ & $\begin{array}{ll}1 & 034 \\
1 & 041 \\
1 & 048 \\
1 & 054 \\
1 & 062\end{array}$ \\
\hline $\begin{array}{ll}0 & 73 \\
0 & 87 \\
1 & 02 \\
1 & 16 \\
1 & 31\end{array}$ & $\begin{array}{l}5 \\
6 \\
7 \\
8 \\
9\end{array}$ & $\begin{array}{l}3447 \\
4137 \\
4826 \\
5516 \\
6205\end{array}$ & $\begin{array}{l}798 \\
812 \\
827 \\
841 \\
856\end{array}$ & $\begin{array}{l}55 \\
56 \\
57 \\
58 \\
59\end{array}$ & $\begin{array}{l}3792 \\
3861 \\
3930 \\
3999 \\
4068\end{array}$ & $\begin{array}{l}1523 \\
1537 \\
1552 \\
1566 \\
1581\end{array}$ & $\begin{array}{l}105 \\
106 \\
107 \\
108 \\
109\end{array}$ & $\begin{array}{l}7240 \\
7308 \\
7377 \\
7446 \\
7515\end{array}$ & $\begin{array}{l}2248 \\
2263 \\
2277 \\
2292 \\
2306\end{array}$ & $\begin{array}{l}155 \\
156 \\
157 \\
158 \\
159\end{array}$ & $\begin{array}{l}1069 \\
1076 \\
1082 \\
1089 \\
1096\end{array}$ \\
\hline $\begin{array}{l}145 \\
160 \\
174 \\
189 \\
203\end{array}$ & $\begin{array}{l}10 \\
11 \\
12 \\
13 \\
14\end{array}$ & $\begin{array}{l}6895 \\
7584 \\
8274 \\
8963 \\
9653\end{array}$ & $\begin{array}{l}870 \\
885 \\
899 \\
914 \\
928\end{array}$ & $\begin{array}{l}60 \\
61 \\
62 \\
63 \\
64\end{array}$ & $\begin{array}{l}4137 \\
4206 \\
4275 \\
4344 \\
4413\end{array}$ & $\begin{array}{l}1595 \\
1610 \\
1624 \\
1639 \\
1653\end{array}$ & $\begin{array}{l}110 \\
111 \\
112 \\
113 \\
114\end{array}$ & $\begin{array}{l}7584 \\
7653 \\
7722 \\
7791 \\
7860\end{array}$ & $\begin{array}{l}2321 \\
2335 \\
2350 \\
2364 \\
2379\end{array}$ & $\begin{array}{l}160 \\
161 \\
162 \\
163 \\
164\end{array}$ & $\begin{array}{ll}1 & 103 \\
1 & 110 \\
1 & 117 \\
1 & 124 \\
1 & 131\end{array}$ \\
\hline $\begin{array}{l}218 \\
232 \\
247 \\
261 \\
276\end{array}$ & $\begin{array}{l}15 \\
16 \\
17 \\
18 \\
19\end{array}$ & $\begin{array}{l}1034 \\
1103 \\
1172 \\
1241 \\
1310\end{array}$ & $\begin{array}{r}943 \\
957 \\
972 \\
986 \\
1001\end{array}$ & $\begin{array}{l}65 \\
66 \\
67 \\
68 \\
69\end{array}$ & $\begin{array}{l}4482 \\
4551 \\
4620 \\
4688 \\
4757\end{array}$ & $\begin{array}{l}1668 \\
1682 \\
1697 \\
1711 \\
1726\end{array}$ & $\begin{array}{l}115 \\
116 \\
117 \\
118 \\
119\end{array}$ & $\begin{array}{l}7929 \\
7998 \\
8067 \\
8136 \\
8205\end{array}$ & $\begin{array}{l}2393 \\
2408 \\
2422 \\
2437 \\
2451\end{array}$ & $\begin{array}{l}165 \\
166 \\
167 \\
168 \\
169\end{array}$ & $\begin{array}{ll}1 & 138 \\
1 & 145 \\
1 & 151 \\
1 & 158 \\
1 & 165\end{array}$ \\
\hline $\begin{array}{l}290 \\
305 \\
319 \\
334 \\
348\end{array}$ & $\begin{array}{l}20 \\
21 \\
22 \\
23 \\
24\end{array}$ & $\begin{array}{l}1379 \\
1448 \\
1517 \\
1586 \\
1655\end{array}$ & $\begin{array}{l}1015 \\
1030 \\
1044 \\
1059 \\
1073\end{array}$ & $\begin{array}{l}70 \\
71 \\
72 \\
73 \\
74\end{array}$ & $\begin{array}{l}4826 \\
4895 \\
4964 \\
5033 \\
5102\end{array}$ & $\begin{array}{l}1740 \\
1755 \\
1769 \\
1784 \\
1798\end{array}$ & $\begin{array}{l}120 \\
121 \\
122 \\
123 \\
124\end{array}$ & $\begin{array}{l}8274 \\
8343 \\
8412 \\
8481 \\
8550\end{array}$ & $\begin{array}{l}2466 \\
2480 \\
2495 \\
2509 \\
2524\end{array}$ & $\begin{array}{l}170 \\
171 \\
172 \\
173 \\
174\end{array}$ & $\begin{array}{ll}1 & 172 \\
1 & 179 \\
1 & 186 \\
1 & 193 \\
1 & 200\end{array}$ \\
\hline $\begin{array}{l}363 \\
377 \\
392 \\
406 \\
421\end{array}$ & $\begin{array}{l}25 \\
26 \\
27 \\
28 \\
29\end{array}$ & $\begin{array}{l}1724 \\
1793 \\
1862 \\
1931 \\
1999\end{array}$ & $\begin{array}{ll}10 & 88 \\
11 & 02 \\
11 & 17 \\
11 & 31 \\
11 & 46\end{array}$ & $\begin{array}{l}75 \\
76 \\
77 \\
78 \\
79\end{array}$ & $\begin{array}{l}5171 \\
5240 \\
5309 \\
5378 \\
5447\end{array}$ & $\begin{array}{l}1813 \\
1827 \\
1842 \\
1856 \\
1871\end{array}$ & $\begin{array}{l}125 \\
126 \\
127 \\
128 \\
129\end{array}$ & $\begin{array}{l}8618 \\
8687 \\
8756 \\
8825 \\
8894\end{array}$ & $\begin{array}{l}2538 \\
2553 \\
2567 \\
2582 \\
2596\end{array}$ & $\begin{array}{l}175 \\
176 \\
177 \\
178 \\
179\end{array}$ & $\begin{array}{l}1207 \\
1213 \\
1220 \\
1227 \\
11234\end{array}$ \\
\hline $\begin{array}{l}435 \\
450 \\
464 \\
479 \\
493\end{array}$ & $\begin{array}{l}30 \\
31 \\
32 \\
33 \\
34\end{array}$ & $\begin{array}{l}2068 \\
2137 \\
2206 \\
2275 \\
2344\end{array}$ & $\begin{array}{l}1160 \\
1175 \\
1189 \\
1204 \\
1218\end{array}$ & $\begin{array}{l}80 \\
81 \\
82 \\
83 \\
84\end{array}$ & $\begin{array}{l}5516 \\
5585 \\
5654 \\
5723 \\
5792\end{array}$ & $\begin{array}{l}1885 \\
1900 \\
1914 \\
1929 \\
1944\end{array}$ & $\begin{array}{l}130 \\
131 \\
132 \\
133 \\
134\end{array}$ & $\begin{array}{l}8963 \\
9032 \\
9101 \\
9170 \\
9239\end{array}$ & $\begin{array}{ll}26 & 11 \\
26 & 25 \\
26 & 40 \\
26 & 54 \\
26 & 69\end{array}$ & $\begin{array}{l}180 \\
181 \\
182 \\
183 \\
184\end{array}$ & $\begin{array}{l}1241 \\
1248 \\
1255 \\
1262 \\
1269\end{array}$ \\
\hline $\begin{array}{l}508 \\
522 \\
537 \\
551 \\
566\end{array}$ & $\begin{array}{l}35 \\
36 \\
37 \\
38 \\
39\end{array}$ & $\begin{array}{l}2413 \\
2482 \\
2551 \\
2620 \\
2689\end{array}$ & $\begin{array}{l}1233 \\
1247 \\
1262 \\
1276 \\
1291\end{array}$ & $\begin{array}{l}85 \\
86 \\
87 \\
88 \\
89\end{array}$ & $\begin{array}{l}5861 \\
5930 \\
5998 \\
6067 \\
6136\end{array}$ & $\begin{array}{l}1958 \\
1973 \\
1987 \\
2002 \\
2016\end{array}$ & $\begin{array}{l}135 \\
136 \\
137 \\
138 \\
139\end{array}$ & $\begin{array}{l}9308 \\
9377 \\
9446 \\
9515 \\
9584\end{array}$ & $\begin{array}{l}2683 \\
2698 \\
2712 \\
2727 \\
2741\end{array}$ & $\begin{array}{l}185 \\
186 \\
187 \\
188 \\
189\end{array}$ & $\begin{array}{l}1276 \\
1282 \\
1289 \\
1296 \\
1303\end{array}$ \\
\hline $\begin{array}{l}580 \\
595 \\
609 \\
624 \\
638\end{array}$ & $\begin{array}{l}40 \\
41 \\
42 \\
43 \\
44\end{array}$ & $\begin{array}{l}2758 \\
2827 \\
2896 \\
2965 \\
3034\end{array}$ & $\begin{array}{l}1305 \\
1320 \\
1334 \\
1349 \\
1363\end{array}$ & $\begin{array}{l}90 \\
91 \\
92 \\
93 \\
94\end{array}$ & $\begin{array}{l}6205 \\
6274 \\
6343 \\
6412 \\
6481\end{array}$ & $\begin{array}{l}20 \quad 31 \\
20 \quad 45 \\
20 \quad 60 \\
20 \quad 74 \\
20 \quad 89\end{array}$ & $\begin{array}{l}140 \\
141 \\
142 \\
143 \\
144\end{array}$ & $\begin{array}{l}9653 \\
9722 \\
9791 \\
9860 \\
9929\end{array}$ & $\begin{array}{l}2756 \\
2770 \\
2785 \\
2799 \\
2814\end{array}$ & $\begin{array}{l}190 \\
191 \\
192 \\
193 \\
194\end{array}$ & $\begin{array}{l}1310 \\
1317 \\
1324 \\
1331 \\
1338\end{array}$ \\
\hline $\begin{array}{l}653 \\
667 \\
682 \\
696 \\
711\end{array}$ & $\begin{array}{l}45 \\
46 \\
47 \\
48 \\
49\end{array}$ & $\begin{array}{l}3103 \\
3172 \\
3241 \\
3310 \\
3378\end{array}$ & $\begin{array}{l}1378 \\
1392 \\
1407 \\
1421 \\
1436\end{array}$ & $\begin{array}{l}95 \\
96 \\
97 \\
98 \\
99\end{array}$ & $\begin{array}{l}6550 \\
6619 \\
6688 \\
6757 \\
6826\end{array}$ & $\begin{array}{ll}21 & 03 \\
21 & 18 \\
21 & 32 \\
21 & 47 \\
21 & 61\end{array}$ & $\begin{array}{l}145 \\
146 \\
147 \\
148 \\
149\end{array}$ & $\begin{array}{l}9997 \\
1007 \\
1014 \\
1020 \\
1027\end{array}$ & $\begin{array}{l}2828 \\
2843 \\
2857 \\
2872 \\
2886\end{array}$ & $\begin{array}{l}195 \\
196 \\
197 \\
198 \\
199\end{array}$ & $\begin{array}{l}1344 \\
1351 \\
1358 \\
1365 \\
1372\end{array}$ \\
\hline 725 & 50 & 34471 & 1450 & 100 & 6895 & 2176 & 150 & 1034 & 2901 & 200 & 1379 \\
\hline
\end{tabular}

Reproduced from the Mid-June 1980 METAL PROGRESS DATABOOK by permission from American Society for Metals, Metals Park, Ohio 44073. 


\section{ENGLISH/METRIC (SI) STRESS CONVERSION FACTORS (Cont inued)}

To cunvert ksı or MPa values above 400 use the supplemental table Example Convert $1320 \mathrm{MPa}$ to ksi Solution $1000 \mathrm{MPa} 14504 \mathrm{ks}$ (from the small table) and $320 \mathrm{MPa} 4641 \mathrm{ks}$ (from the large table) Then, $14504 \quad 4641 \quad 19145 \mathrm{ksi}$

\begin{tabular}{|c|c|c|c|c|c|}
\hline ksi & & $\begin{array}{r}200 \\
\mathrm{MPa}\end{array}$ & 300 & & $\mathrm{MPa}$ \\
\hline $\begin{array}{l}2901 \\
2915 \\
2930 \\
2944 \\
2959\end{array}$ & $\begin{array}{l}200 \\
201 \\
202 \\
203 \\
204\end{array}$ & $\begin{array}{l}1379 \\
1386 \\
1393 \\
1400 \\
1407\end{array}$ & $\begin{array}{l}3626 \\
3640 \\
3655 \\
3669 \\
3684\end{array}$ & $\begin{array}{l}250 \\
251 \\
252 \\
253 \\
254\end{array}$ & $\begin{array}{l}1724 \\
1731 \\
1737 \\
1744 \\
1751\end{array}$ \\
\hline $\begin{array}{l}2973 \\
2988 \\
3002 \\
3017 \\
3031\end{array}$ & $\begin{array}{l}205 \\
206 \\
207 \\
208 \\
209\end{array}$ & $\begin{array}{l}1413 \\
1420 \\
1427 \\
1434 \\
1441\end{array}$ & $\begin{array}{l}3698 \\
3713 \\
3727 \\
3742 \\
3756\end{array}$ & $\begin{array}{l}255 \\
256 \\
257 \\
258 \\
259\end{array}$ & $\begin{array}{l}1758 \\
1765 \\
1772 \\
1779 \\
1786\end{array}$ \\
\hline $\begin{array}{l}3046 \\
3060 \\
3075 \\
3089 \\
3104\end{array}$ & $\begin{array}{l}210 \\
211 \\
212 \\
213 \\
214\end{array}$ & $\begin{array}{l}1448 \\
1455 \\
1462 \\
1169 \\
1475\end{array}$ & $\begin{array}{l}3771 \\
3785 \\
3800 \\
3814 \\
3829\end{array}$ & $\begin{array}{l}260 \\
261 \\
262 \\
263 \\
264\end{array}$ & $\begin{array}{l}1793 \\
1800 \\
1806 \\
1813 \\
1820\end{array}$ \\
\hline $\begin{array}{l}3118 \\
3133 \\
3147 \\
3162 \\
3176\end{array}$ & $\begin{array}{l}215 \\
216 \\
217 \\
218 \\
219\end{array}$ & $\begin{array}{l}1482 \\
1489 \\
1496 \\
1503 \\
1510\end{array}$ & $\begin{array}{l}3843 \\
3858 \\
3873 \\
3887 \\
3902\end{array}$ & $\begin{array}{l}265 \\
266 \\
267 \\
268 \\
269\end{array}$ & $\begin{array}{l}1827 \\
1834 \\
1841 \\
1848 \\
1855\end{array}$ \\
\hline $\begin{array}{l}3191 \\
3205 \\
3220 \\
3234 \\
3249\end{array}$ & $\begin{array}{l}220 \\
221 \\
222 \\
223 \\
224\end{array}$ & $\begin{array}{l}1517 \\
1524 \\
1531 \\
1538 \\
1544\end{array}$ & $\begin{array}{l}3916 \\
3931 \\
3945 \\
3960 \\
3974\end{array}$ & $\begin{array}{l}270 \\
271 \\
272 \\
273 \\
274\end{array}$ & $\begin{array}{l}1862 \\
1868 \\
1875 \\
1882 \\
1889\end{array}$ \\
\hline $\begin{array}{l}3263 \\
3278 \\
3292 \\
3307 \\
3321\end{array}$ & $\begin{array}{l}225 \\
226 \\
227 \\
228 \\
229\end{array}$ & $\begin{array}{l}1551 \\
1558 \\
1565 \\
1572 \\
1579\end{array}$ & $\begin{array}{l}3989 \\
4003 \\
4018 \\
4032 \\
4047\end{array}$ & $\begin{array}{l}275 \\
276 \\
277 \\
278 \\
279\end{array}$ & $\begin{array}{l}1896 \\
1903 \\
1910 \\
1917 \\
1924\end{array}$ \\
\hline $\begin{array}{l}3336 \\
3350 \\
3365 \\
3379 \\
3394\end{array}$ & $\begin{array}{l}230 \\
231 \\
232 \\
233 \\
234\end{array}$ & $\begin{array}{l}1586 \\
1593 \\
1600 \\
1606 \\
1613\end{array}$ & $\begin{array}{l}4061 \\
4076 \\
4090 \\
4105 \\
4119\end{array}$ & $\begin{array}{l}280 \\
281 \\
282 \\
283 \\
284\end{array}$ & $\begin{array}{l}1931 \\
1937 \\
1944 \\
1951 \\
1958\end{array}$ \\
\hline $\begin{array}{l}3408 \\
3423 \\
3437 \\
3452 \\
3466\end{array}$ & $\begin{array}{l}235 \\
236 \\
237 \\
238 \\
239\end{array}$ & $\begin{array}{l}1620 \\
1627 \\
1634 \\
1641 \\
1648\end{array}$ & $\begin{array}{lll}41 & 34 \\
41 & 48 \\
41 & 63 \\
41 & 77 \\
41 & 92\end{array}$ & $\begin{array}{l}285 \\
286 \\
287 \\
288 \\
289\end{array}$ & $\begin{array}{l}1965 \\
1972 \\
1979 \\
1986 \\
1993\end{array}$ \\
\hline $\begin{array}{l}3481 \\
3495 \\
3510 \\
3524 \\
3539\end{array}$ & $\begin{array}{l}240 \\
241 \\
242 \\
243 \\
244\end{array}$ & $\begin{array}{l}1655 \\
1662 \\
1669 \\
1675 \\
1682\end{array}$ & $\begin{array}{l}4206 \\
4221 \\
4235 \\
4250 \\
4264\end{array}$ & $\begin{array}{l}290 \\
291 \\
292 \\
293 \\
294\end{array}$ & $\begin{array}{l}1999 \\
2006 \\
2013 \\
2020 \\
2027\end{array}$ \\
\hline $\begin{array}{l}3553 \\
3568 \\
3582 \\
3597 \\
3611\end{array}$ & $\begin{array}{l}245 \\
246 \\
247 \\
248 \\
249\end{array}$ & $\begin{array}{l}1689 \\
1696 \\
1703 \\
1710 \\
1717\end{array}$ & $\begin{array}{l}4279 \\
4293 \\
4307 \\
4322 \\
4337\end{array}$ & $\begin{array}{l}295 \\
296 \\
297 \\
298 \\
299\end{array}$ & $\begin{array}{l}2034 \\
2041 \\
2048 \\
2055 \\
2062\end{array}$ \\
\hline 3626 & 250 & 1724 & 4351 & 300 & 2068 \\
\hline
\end{tabular}

\begin{tabular}{|c|c|c|c|c|c|c|c|c|}
\hline kSI & & $\begin{array}{r}300 \\
\mathrm{MPa}\end{array}$ & 400 & & $\mathrm{MPa}$ & & & \\
\hline $\begin{array}{l}4351 \\
4366 \\
4380 \\
4395 \\
4409\end{array}$ & $\begin{array}{l}300 \\
301 \\
302 \\
303 \\
304\end{array}$ & $\begin{array}{l}2068 \\
2075 \\
2082 \\
2089 \\
2096\end{array}$ & $\begin{array}{l}5076 \\
5091 \\
5105 \\
5120 \\
5134\end{array}$ & $\begin{array}{l}350 \\
351 \\
352 \\
353 \\
354\end{array}$ & $\begin{array}{l}2413 \\
2420 \\
2427 \\
2434 \\
2441\end{array}$ & & & \\
\hline $\begin{array}{l}4424 \\
4438 \\
4453 \\
4467 \\
4482\end{array}$ & $\begin{array}{l}305 \\
306 \\
307 \\
308 \\
309\end{array}$ & $\begin{array}{ll}2 & 103 \\
2 & 110 \\
2 & 117 \\
2 & 124 \\
2 & 130\end{array}$ & $\begin{array}{l}5149 \\
5163 \\
5178 \\
5192 \\
5207\end{array}$ & $\begin{array}{l}355 \\
356 \\
357 \\
358 \\
359\end{array}$ & $\begin{array}{l}2448 \\
2455 \\
2461 \\
2468 \\
2475\end{array}$ & & & \\
\hline $\begin{array}{l}4496 \\
4511 \\
4525 \\
4540 \\
4554\end{array}$ & $\begin{array}{l}310 \\
311 \\
312 \\
313 \\
314\end{array}$ & $\begin{array}{ll}2 & 137 \\
2 & 144 \\
2 & 151 \\
2 & 158 \\
2 & 165\end{array}$ & $\begin{array}{l}5221 \\
5236 \\
5250 \\
5265 \\
5279\end{array}$ & $\begin{array}{l}360 \\
361 \\
362 \\
363 \\
364\end{array}$ & $\begin{array}{l}2482 \\
2489 \\
2496 \\
2503 \\
2510\end{array}$ & & & \\
\hline $\begin{array}{l}4569 \\
4583 \\
4598 \\
4612 \\
4627\end{array}$ & $\begin{array}{l}315 \\
316 \\
317 \\
318 \\
319\end{array}$ & $\begin{array}{ll}2 & 172 \\
2 & 179 \\
2 & 186 \\
2 & 193 \\
2 & 199\end{array}$ & $\begin{array}{l}5294 \\
5308 \\
5323 \\
5337 \\
5352\end{array}$ & $\begin{array}{l}365 \\
366 \\
367 \\
368 \\
369\end{array}$ & $\begin{array}{l}2517 \\
2523 \\
2530 \\
2537 \\
2544\end{array}$ & & & \\
\hline $\begin{array}{l}4641 \\
4656 \\
4670 \\
4685 \\
4699\end{array}$ & $\begin{array}{l}320 \\
321 \\
322 \\
323 \\
324\end{array}$ & $\begin{array}{l}2206 \\
2213 \\
2220 \\
2227 \\
2234\end{array}$ & $\begin{array}{l}5366 \\
5381 \\
5395 \\
5410 \\
5424\end{array}$ & $\begin{array}{l}370 \\
371 \\
372 \\
373 \\
374\end{array}$ & $\begin{array}{l}2551 \\
2558 \\
2565 \\
2572 \\
2579\end{array}$ & & & \\
\hline $\begin{array}{l}4714 \\
4728 \\
4743 \\
4757 \\
4772\end{array}$ & $\begin{array}{l}325 \\
326 \\
327 \\
328 \\
329\end{array}$ & $\begin{array}{l}2241 \\
2248 \\
2255 \\
2261 \\
2268\end{array}$ & $\begin{array}{l}5439 \\
5453 \\
5468 \\
5482 \\
5497\end{array}$ & $\begin{array}{l}375 \\
376 \\
377 \\
378 \\
379\end{array}$ & $\begin{array}{l}2585 \\
2592 \\
2599 \\
2606 \\
2613\end{array}$ & & & \\
\hline $\begin{array}{l}4786 \\
4801 \\
4815 \\
4830 \\
4844\end{array}$ & $\begin{array}{l}330 \\
331 \\
332 \\
333 \\
334\end{array}$ & $\begin{array}{l}2275 \\
2282 \\
2289 \\
2296 \\
2303\end{array}$ & $\begin{array}{l}5511 \\
5526 \\
5540 \\
5555 \\
5569\end{array}$ & $\begin{array}{l}380 \\
381 \\
382 \\
383 \\
384\end{array}$ & $\begin{array}{l}2620 \\
2627 \\
2634 \\
2,641 \\
2648\end{array}$ & & & \\
\hline $\begin{array}{l}4859 \\
4873 \\
4888 \\
4902 \\
4917\end{array}$ & $\begin{array}{l}335 \\
336 \\
337 \\
338 \\
339\end{array}$ & $\begin{array}{l}2310 \\
2317 \\
2324 \\
2330 \\
2337\end{array}$ & $\begin{array}{l}5584 \\
5598 \\
5613 \\
5627 \\
5642\end{array}$ & $\begin{array}{l}\mathbf{3 8 5} \\
\mathbf{3 8 6} \\
\mathbf{3 8 7} \\
\mathbf{3 8 8} \\
\mathbf{3 8 9}\end{array}$ & $\begin{array}{l}2654 \\
2661 \\
2668 \\
2675 \\
2682\end{array}$ & $\frac{k s 1}{7252}$ & $\begin{array}{l}105000 \\
500\end{array}$ & $\frac{\mathrm{MPa}}{344 \mathrm{I}}$ \\
\hline $\begin{array}{l}4931 \\
4946 \\
4960 \\
4975 \\
4989\end{array}$ & $\begin{array}{l}340 \\
341 \\
342 \\
343 \\
344\end{array}$ & $\begin{array}{l}2344 \\
2351 \\
2358 \\
2365 \\
2372\end{array}$ & $\begin{array}{l}5656 \\
5671 \\
5685 \\
5700 \\
5714\end{array}$ & $\begin{array}{l}390 \\
391 \\
392 \\
393 \\
394\end{array}$ & $\begin{array}{l}2689 \\
2696 \\
2703 \\
2710 \\
2717\end{array}$ & $\begin{array}{r}8702 \\
10153 \\
11603 \\
13053\end{array}$ & $\begin{array}{l}600 \\
700 \\
800 \\
900\end{array}$ & $\begin{array}{l}4137 \\
4826 \\
5516 \\
6205\end{array}$ \\
\hline $\begin{array}{l}5004 \\
5018 \\
5033 \\
5047 \\
5062\end{array}$ & $\begin{array}{l}345 \\
346 \\
347 \\
348 \\
\mathbf{3 4 9}\end{array}$ & $\begin{array}{l}2379 \\
2386 \\
2392 \\
2399 \\
2406\end{array}$ & $\begin{array}{l}5729 \\
5743 \\
5758 \\
5772 \\
5787\end{array}$ & $\begin{array}{l}395 \\
396 \\
397 \\
398 \\
399\end{array}$ & $\begin{array}{l}2723 \\
2730 \\
2737 \\
2744 \\
2751\end{array}$ & $\begin{array}{l}14504 \\
29008 \\
43511 \\
58015\end{array}$ & $\begin{array}{l}1000 \\
2000 \\
3000 \\
4000\end{array}$ & $\begin{array}{r}6895 \\
13790 \\
20684 \\
27579\end{array}$ \\
\hline 5076 & 350 & 2413 & 5802 & 400 & 2758 & 72519 & 5000 & 34474 \\
\hline
\end{tabular}

Source Anton deS Brasunas University of Missouri Rolla 


\section{English/Metric(SI) Fracture Toughness Conversion Factors}

\begin{tabular}{|c|c|c|c|c|c|c|c|c|c|c|}
\hline \multirow[t]{2}{*}{$k s i \sqrt{\text { in. }}$} & 0 & 1 & 2 & 3 & 4 & 5 & 6 & 7 & 8 & 9 \\
\hline & \multicolumn{10}{|c|}{$\mathrm{MPa} \sqrt{\mathrm{m}}$} \\
\hline 0 & - & 11 & 22 & 33 & 44 & 55 & 66 & 77 & 88 & 99 \\
\hline 10 & 110 & 121 & 132 & 143 & 154 & 165 & 176 & 187 & 198 & 209 \\
\hline 20 & 220 & 231 & 242 & 253 & 264 & 275 & 286 & 297 & 308 & 319 \\
\hline 30 & 330 & 341 & 352 & 363 & 374 & 385 & 396 & 407 & 418 & 429 \\
\hline 40 & 440 & 451 & 462 & 473 & 484 & 495 & 506 & 517 & 528 & 538 \\
\hline 50 & 549 & 560 & 571 & 582 & 593 & 604 & 615 & 626 & 637 & 648 \\
\hline 60 & 659 & 670 & 681 & 692 & 703 & 714 & 725 & 736 & 747 & 758 \\
\hline 70 & 769 & 780 & 791 & 802 & 813 & 824 & 835 & 846 & 857 & 868 \\
\hline 80 & 879 & 890 & 901 & 912 & 923 & 934 & 945 & 956 & 967 & 978 \\
\hline 90 & 989 & 100 & 101 & 102 & 103 & 104 & 105 & 107 & 108 & 109 \\
\hline 100 & 110 & 111 & 112 & 113 & 114 & 115 & 116 & 118 & 119 & 120 \\
\hline 110 & 121 & 122 & 123 & 124 & 125 & 126 & 127 & 129 & 130 & 131 \\
\hline 120 & 132 & 133 & 134 & 135 & 136 & 137 & 138 & 140 & 141 & 142 \\
\hline 130 & 143 & 144 & 145 & 146 & 147 & 148 & 149 & 151 & 152 & 153 \\
\hline 140 & 154 & 155 & 156 & 157 & 158 & 159 & 160 & 162 & 163 & 164 \\
\hline 150 & 165 & 166 & 167 & 168 & 169 & 170 & 171 & 173 & 174 & 175 \\
\hline 160 & 176 & 177 & 178 & 179 & 180 & 181 & 182 & 184 & 185 & 186 \\
\hline 170 & 187 & 188 & 189 & 190 & 191 & 192 & 193 & 194 & 196 & 197 \\
\hline 180 & 198 & 199 & 200 & 201 & 202 & 203 & 204 & 205 & 207 & 208 \\
\hline 190 & 209 & 210 & 211 & 212 & 213 & 214 & 215 & 216 & 218 & 219 \\
\hline 200 & 220 & 221 & 222 & 223 & 224 & 225 & 226 & 227 & 229 & 230 \\
\hline 210 & 231 & 232 & 233 & 234 & 235 & 236 & 237 & 238 & 240 & 241 \\
\hline 220 & 242 & 243 & 244 & 245 & 246 & 247 & 248 & 249 & 251 & 252 \\
\hline 230 & 253 & 254 & 255 & 256 & 257 & 258 & 259 & 260 & 262 & 263 \\
\hline 240 & 264 & 265 & 266 & 267 & 268 & 269 & 270 & 271 & 273 & 274 \\
\hline 250 & 275 & 276 & 277 & 278 & 279 & 280 & 281 & 282 & 284 & 285 \\
\hline 260 & 286 & 287 & 288 & 289 & 290 & 291 & 292 & 293 & 294 & 296 \\
\hline 270 & 297 & 298 & 299 & 300 & 301 & 302 & 303 & 304 & 305 & 307 \\
\hline 280 & 308 & 309 & 310 & 311 & 312 & 313 & 314 & 315 & 316 & 318 \\
\hline 290 & 319 & 320 & 321 & 322 & 323 & 324 & 325 & 326 & 327 & 329 \\
\hline 300 & 330 & 331 & 332 & 333 & 334 & 335 & 336 & 337 & 338 & 340 \\
\hline 310 & 341 & 342 & 343 & 344 & 345 & 346 & 347 & 348 & 349 & 351 \\
\hline 320 & 352 & 353 & 354 & 355 & 356 & 357 & 358 & 359 & 360 & 362 \\
\hline 330 & 363 & 364 & 365 & 366 & 367 & 368 & 369 & 370 & 371 & 373 \\
\hline 340 & 374 & 375 & 376 & 377 & 378 & 379 & 380 & 381 & 382 & 384 \\
\hline 350 & 385 & 386 & 387 & 388 & 389 & 390 & 391 & 392 & 393 & 394 \\
\hline 360 & 396 & 397 & 398 & 399 & 400 & 401 & 402 & 403 & 404 & 405 \\
\hline 370 & 407 & 408 & 409 & 410 & 411 & 412 & 413 & 414 & 415 & 416 \\
\hline 380 & 418 & 419 & 420 & 421 & 422 & 423 & 424 & 425 & 426 & 427 \\
\hline 390 & 429 & 430 & 431 & 432 & 433 & 434 & 435 & 436 & 437 & 438 \\
\hline 400 & 440 & & & & & & & & & \\
\hline
\end{tabular}

* Precise conversions can be obtained as follows

To convert from ksi $\sqrt{\mathrm{in}}$ to $\mathrm{MPa} \sqrt{\mathrm{m}}$, multiply by 1098844

To convert from $\mathrm{MPa}-\mathrm{m}$ to $\mathrm{ksi} \sqrt{\mathrm{in}}$, multiply by 0910048

(Revised April 1980)

Reproduced from the Mid-June 1980 METAL PROGRESS DATABOOK by permission from American Society for Metals, Metals Park, Ohio 44073. 


\section{English/Metric (SI) Impact Energy Conversion Factors}

Look up impact energy to be converted in boldface column. If in $\mathrm{ft}-\mathrm{Ib}$, read joules $(J)$ in lefthand column. If in joules $(J)$, read $\mathrm{ft}-\mathrm{lb}$ in righthand column Decimal energy values above 10 and all values above 130 can be calculated by addition. For example, $25.5 \mathrm{ft}-1 \mathrm{~b}=33.9(25.0)+0.68(05)$ or $3458 \mathrm{~J}$ Also, $165 \mathrm{~J}=738(100.0)+479(65)$ or $1217 \mathrm{ft}-1 \mathrm{~b}$
Note. Values for conversions are rounded off to simplify calculations Actual conversion factors $(1 \mathrm{ft}-\mathrm{lb}=1.355818$ joules and 1 joule $=$ $0.737562 \mathrm{ft}-\mathrm{lb}$ ) can be used if more accuracy is desired. (Reviewed February 1980)

\begin{tabular}{|c|c|c|c|c|c|}
\hline \multicolumn{6}{|c|}{0.1 to 20} \\
\hline joule (J) & & ft.lb & joule (J) & & $f t-I b$ \\
\hline $\begin{array}{l}0.14 \\
0.27 \\
0.41 \\
0.54 \\
0.68\end{array}$ & $\begin{array}{l}0.1 \\
0.2 \\
0.3 \\
0.4 \\
0.5\end{array}$ & $\begin{array}{l}0.07 \\
0.15 \\
0.22 \\
0.30 \\
0.37\end{array}$ & $\begin{array}{l}7.59 \\
7.73 \\
7.86 \\
8.00 \\
8.13\end{array}$ & $\begin{array}{l}5.6 \\
5.7 \\
5.8 \\
5.9 \\
6.0\end{array}$ & $\begin{array}{l}4.13 \\
4.20 \\
4.28 \\
4.35 \\
4.43\end{array}$ \\
\hline $\begin{array}{l}0.81 \\
0.95 \\
1.08 \\
1.22 \\
1.36\end{array}$ & $\begin{array}{l}0.6 \\
0.7 \\
0.8 \\
0.9 \\
1.0\end{array}$ & $\begin{array}{l}0.44 \\
0.52 \\
0.59 \\
0.66 \\
0.74\end{array}$ & $\begin{array}{l}8.27 \\
8.41 \\
8.54 \\
8.68 \\
8.81\end{array}$ & $\begin{array}{l}6.1 \\
6.2 \\
6.3 \\
6.4 \\
6.5\end{array}$ & $\begin{array}{l}4.50 \\
4.57 \\
4.65 \\
4.72 \\
4.79\end{array}$ \\
\hline $\begin{array}{l}1.49 \\
1.63 \\
1.76 \\
1.90 \\
2.03\end{array}$ & $\begin{array}{l}1.1 \\
1.2 \\
1.3 \\
1.4 \\
1.5\end{array}$ & $\begin{array}{l}0.81 \\
0.89 \\
0.96 \\
1.03 \\
1.11\end{array}$ & $\begin{array}{l}8.95 \\
9.08 \\
9.22 \\
9.36 \\
9.49\end{array}$ & $\begin{array}{l}6.6 \\
6.7 \\
6.8 \\
6.9 \\
7.0\end{array}$ & $\begin{array}{l}4.87 \\
4.94 \\
5.02 \\
5.09 \\
5.16\end{array}$ \\
\hline $\begin{array}{l}2.17 \\
2.30 \\
2.44 \\
2.58 \\
2.71\end{array}$ & $\begin{array}{l}1.6 \\
1.7 \\
1.8 \\
1.9 \\
2.0\end{array}$ & $\begin{array}{l}1.18 \\
1.25 \\
1.33 \\
1.40 \\
1.48\end{array}$ & $\begin{array}{l}9.63 \\
9.76 \\
9.90 \\
10.0 \\
10.2\end{array}$ & $\begin{array}{l}7.1 \\
7.2 \\
7.3 \\
7.4 \\
7.5\end{array}$ & $\begin{array}{l}5.24 \\
5.31 \\
5.38 \\
5.46 \\
5.53\end{array}$ \\
\hline $\begin{array}{l}2.85 \\
2.98 \\
3.12 \\
3.25 \\
3.39\end{array}$ & $\begin{array}{l}2.1 \\
2.2 \\
2.3 \\
2.4 \\
2.5\end{array}$ & $\begin{array}{l}1.55 \\
1.62 \\
1.70 \\
1.77 \\
1.84\end{array}$ & $\begin{array}{l}10.3 \\
10.4 \\
10.6 \\
10.7 \\
10.8\end{array}$ & $\begin{array}{l}7.6 \\
7.7 \\
7.8 \\
7.9 \\
8.0\end{array}$ & $\begin{array}{l}5.61 \\
5.68 \\
5.75 \\
5.83 \\
5.90\end{array}$ \\
\hline $\begin{array}{l}3.53 \\
3.66 \\
3.80 \\
3.93 \\
4.07\end{array}$ & $\begin{array}{l}2.6 \\
2.7 \\
2.8 \\
2.9 \\
3.0\end{array}$ & $\begin{array}{l}1.92 \\
1.99 \\
2.07 \\
2.14 \\
2.21\end{array}$ & $\begin{array}{l}11.0 \\
11.1 \\
11.3 \\
11.4 \\
11.5\end{array}$ & $\begin{array}{l}8.1 \\
8.2 \\
8.3 \\
8.4 \\
8.5\end{array}$ & $\begin{array}{l}5.97 \\
6.05 \\
6.12 \\
6.20 \\
6.27\end{array}$ \\
\hline $\begin{array}{l}4.20 \\
4.34 \\
4.47 \\
4.61 \\
4.75\end{array}$ & $\begin{array}{l}3.1 \\
3.2 \\
3.3 \\
3.4 \\
3.5\end{array}$ & $\begin{array}{l}2.29 \\
2.36 \\
2.43 \\
2.51 \\
2.58\end{array}$ & $\begin{array}{l}11.7 \\
11.8 \\
11.9 \\
12.1 \\
12.2\end{array}$ & $\begin{array}{l}8.6 \\
8.7 \\
8.8 \\
8.9 \\
9.0\end{array}$ & $\begin{array}{l}6.34 \\
6.42 \\
6.49 \\
6.56 \\
6.64\end{array}$ \\
\hline $\begin{array}{l}4.88 \\
5.02 \\
5.15 \\
5.29 \\
5.42\end{array}$ & $\begin{array}{l}3.6 \\
3.7 \\
3.8 \\
3.9 \\
4.0\end{array}$ & $\begin{array}{l}2.66 \\
2.73 \\
2.80 \\
2.88 \\
2.95\end{array}$ & $\begin{array}{l}12.3 \\
12.5 \\
12.6 \\
12.7 \\
12.9\end{array}$ & $\begin{array}{l}9.1 \\
9.2 \\
9.3 \\
9.4 \\
9.5\end{array}$ & $\begin{array}{l}6.71 \\
6.79 \\
6.86 \\
6.93 \\
7.01\end{array}$ \\
\hline $\begin{array}{l}5.56 \\
5.69 \\
5.83 \\
5.97 \\
6.10\end{array}$ & $\begin{array}{l}4.1 \\
4.2 \\
4.3 \\
4.4 \\
4.5\end{array}$ & $\begin{array}{l}3.02 \\
3.10 \\
3.17 \\
3.25 \\
3.32\end{array}$ & $\begin{array}{l}13.0 \\
13.2 \\
13.3 \\
13.4 \\
13.6\end{array}$ & $\begin{array}{r}9.6 \\
9.7 \\
9.8 \\
9.9 \\
10.0\end{array}$ & $\begin{array}{l}7.08 \\
7.15 \\
7.23 \\
7.30 \\
7.38\end{array}$ \\
\hline $\begin{array}{l}6.24 \\
6.37 \\
6.51 \\
6.64 \\
6.78\end{array}$ & $\begin{array}{l}4.6 \\
4.7 \\
4.8 \\
4.9 \\
5.0\end{array}$ & $\begin{array}{l}3.39 \\
3.47 \\
3.54 \\
3.61 \\
3.69\end{array}$ & $\begin{array}{l}14.9 \\
16.3 \\
17.6 \\
19.0 \\
20.3\end{array}$ & $\begin{array}{l}11.0 \\
12.0 \\
13.0 \\
14.0 \\
15.0\end{array}$ & $\begin{array}{l}8.11 \\
8.85 \\
9.59 \\
10.3 \\
11.1\end{array}$ \\
\hline $\begin{array}{l}6.91 \\
7.05 \\
7.19 \\
7.32 \\
7.46\end{array}$ & $\begin{array}{l}5.1 \\
5.2 \\
5.3 \\
5.4 \\
5.5\end{array}$ & $\begin{array}{l}3.76 \\
3.84 \\
3.91 \\
3.98 \\
4.06\end{array}$ & $\begin{array}{l}21.7 \\
23.0 \\
24.4 \\
25.8 \\
27.1\end{array}$ & $\begin{array}{l}16.0 \\
17.0 \\
18.0 \\
19.0 \\
200\end{array}$ & $\begin{array}{l}11.8 \\
12.5 \\
13.3 \\
14.0 \\
14.8\end{array}$ \\
\hline
\end{tabular}

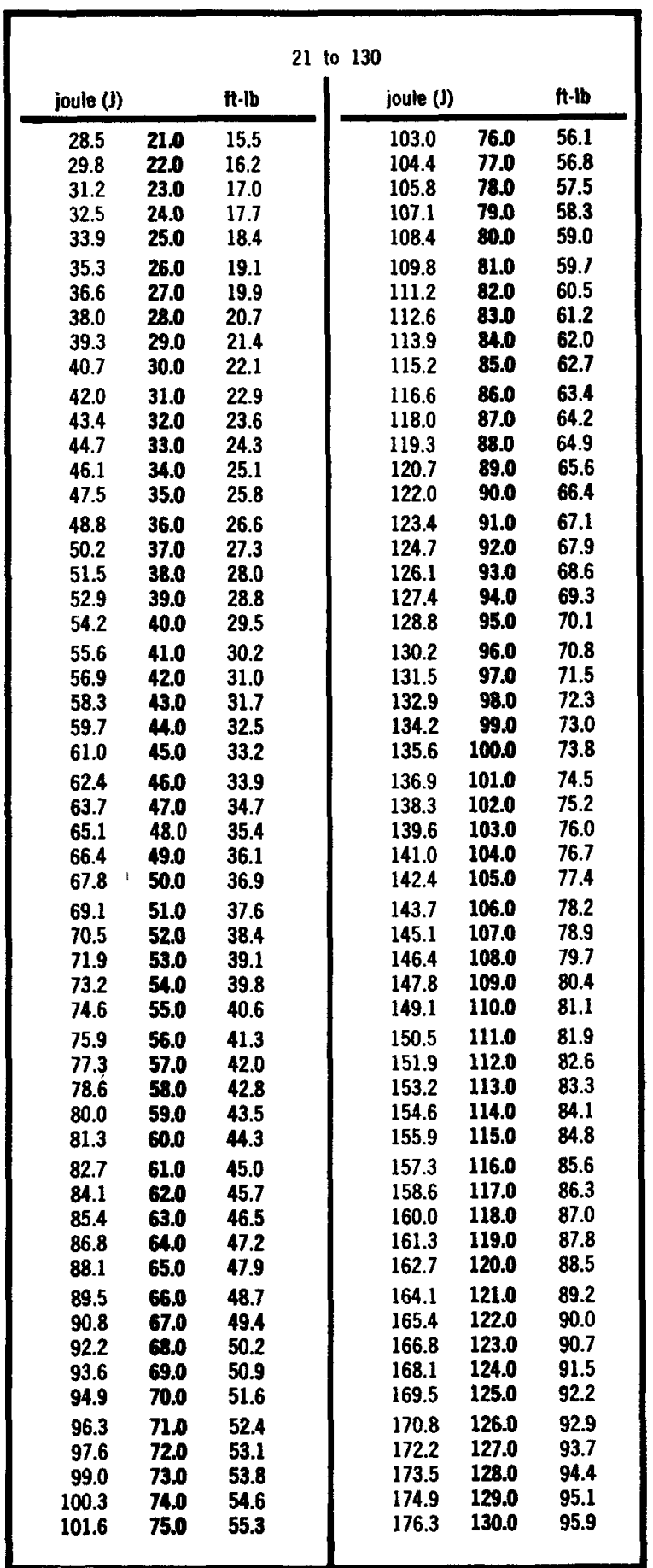

Reproduced from the Mid-June 1980 METAL PROGRESS DATABOOK by permission from American Society for Metals, Metals Park, Ohio 44073. 


\section{APPENDIX C. MECHANICAL TEST SPECIMENS}

\section{APPENDIX C-1}

Smooth Bar Tensile Test Specimen A

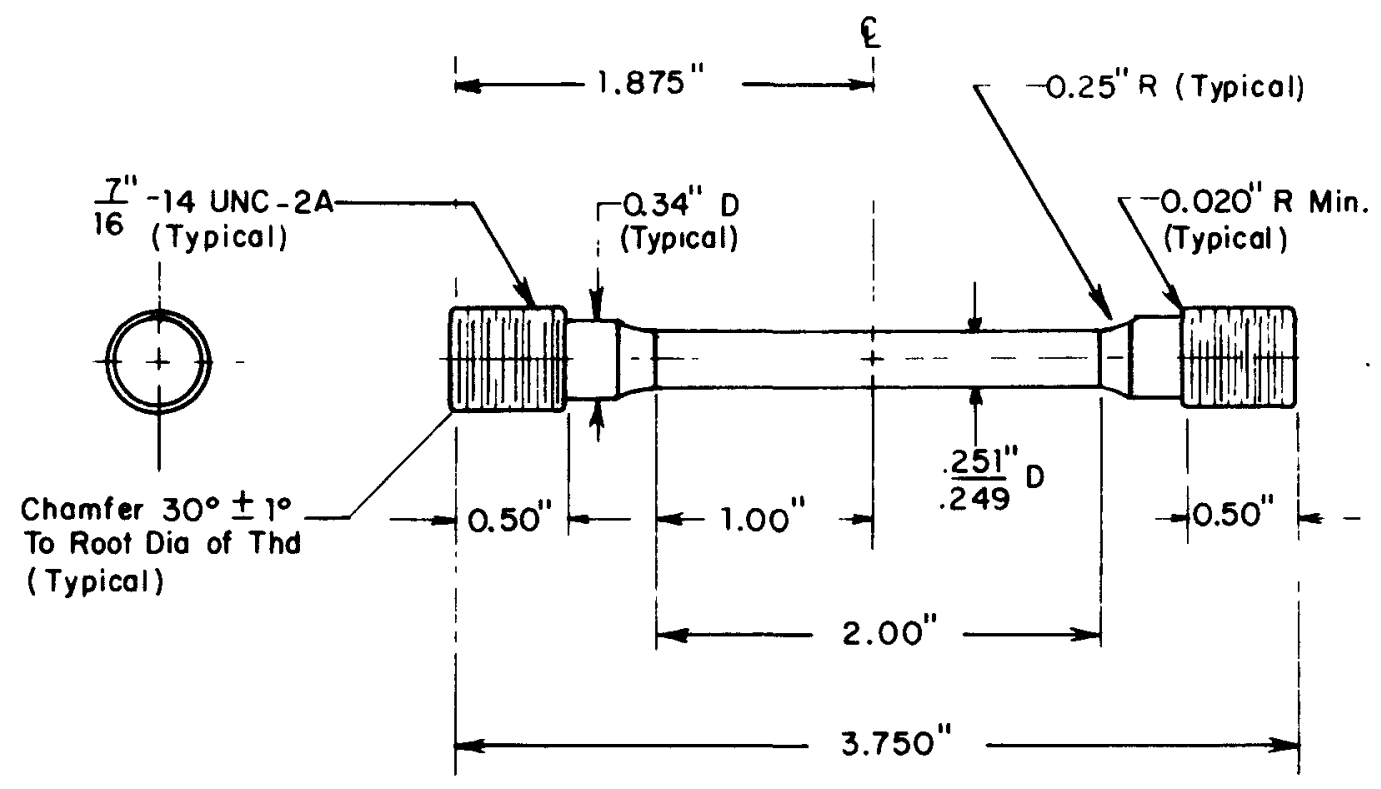




\section{APPENDIX $\mathrm{C}-2$}

Smooth Bar Tensile Test Specimen B

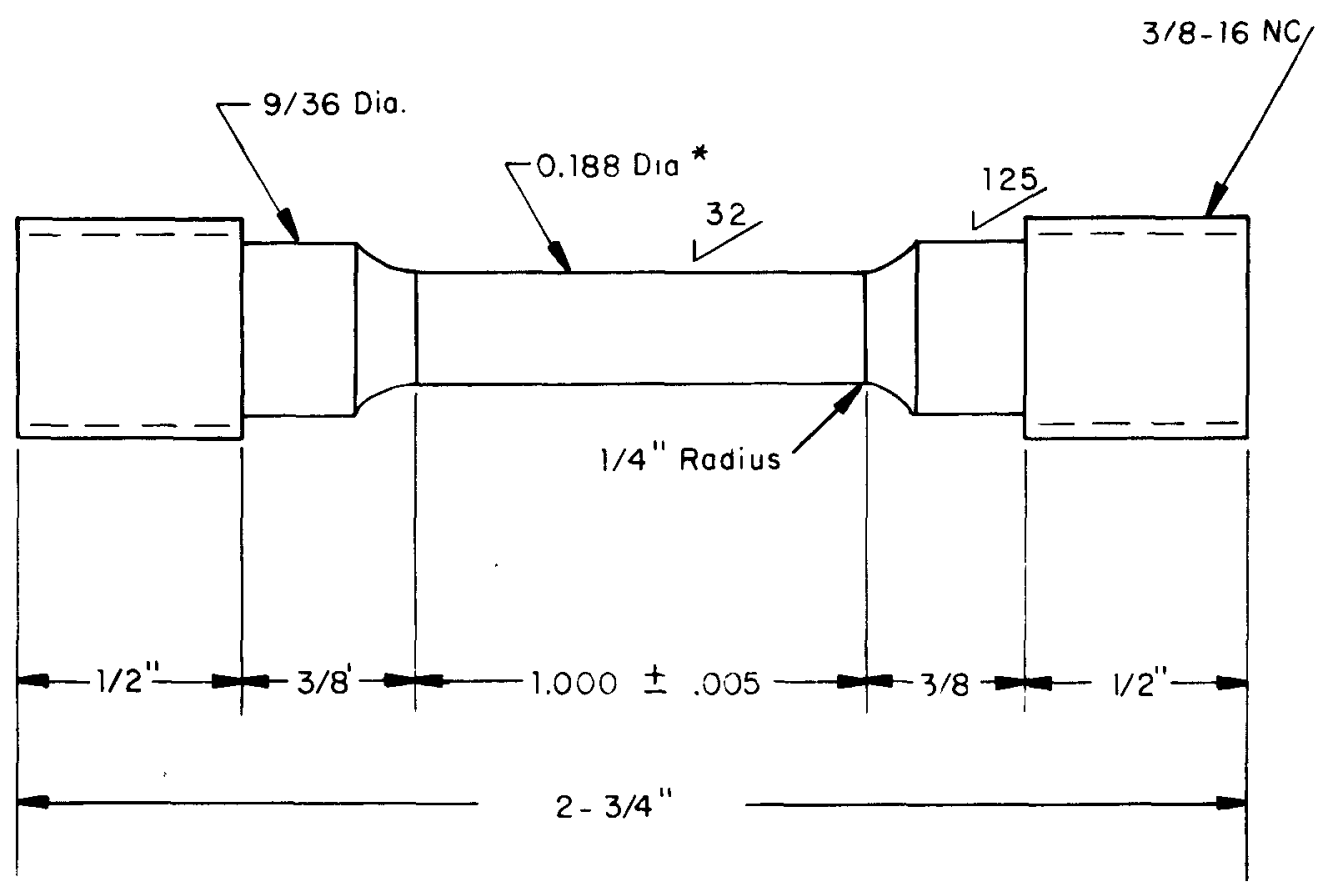

* Increase diameter from center of gage (.188) to the ends by 0.002 " 
APPENDIX C-3

Smooth Bar Tensile Test Specimen C

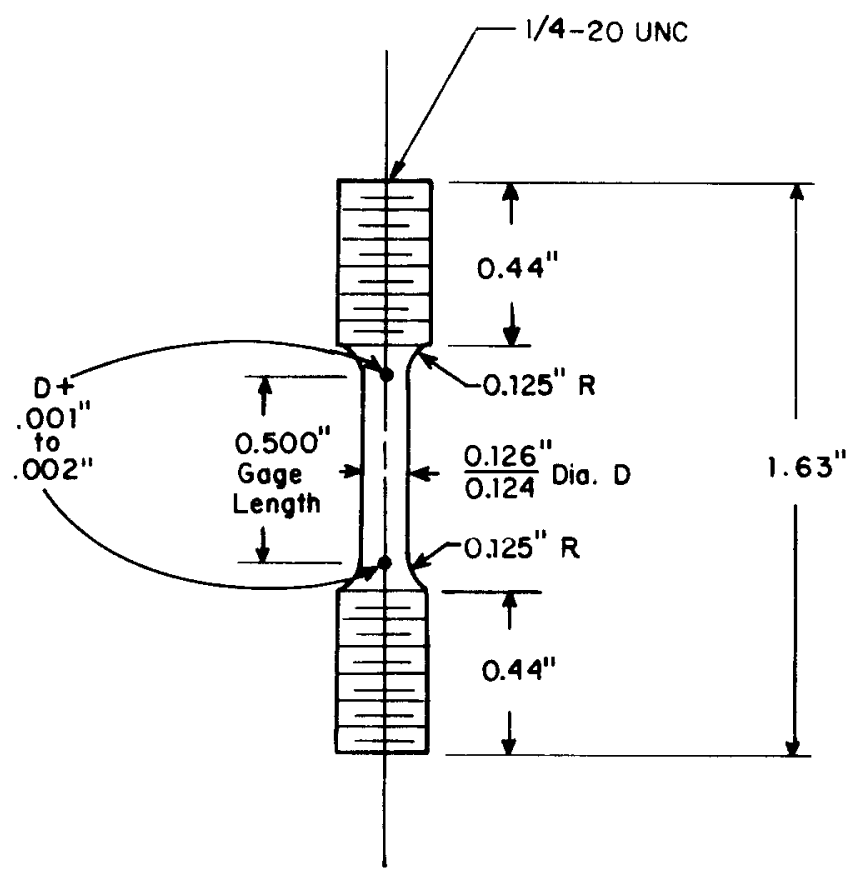


APPENDIX $\mathbf{C}-4$

Circumferential Notch at Center of Specimen

for Notched Tensile Specimens

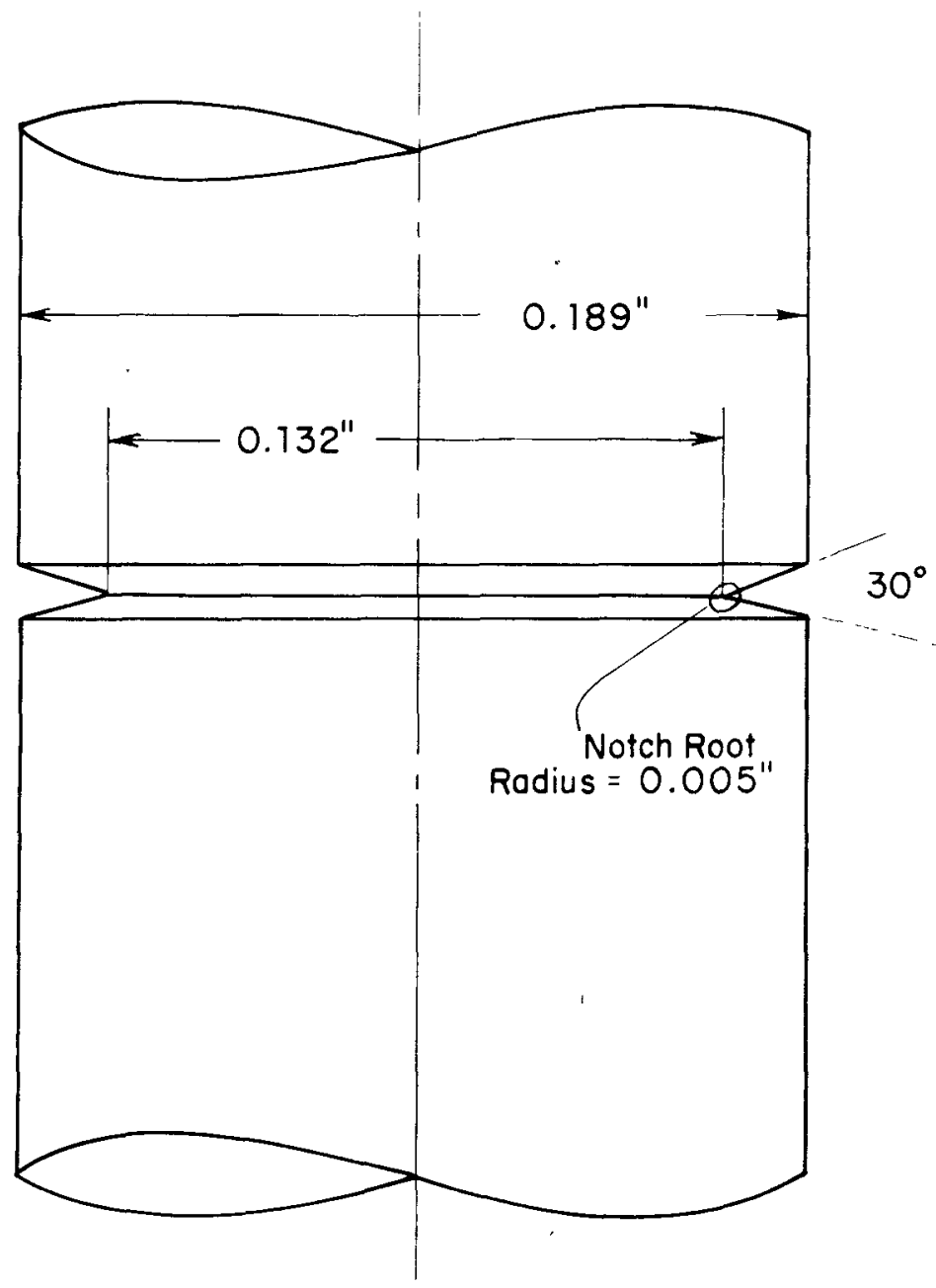


APPENDIX C-5

\section{Tensile Tube Specimen}

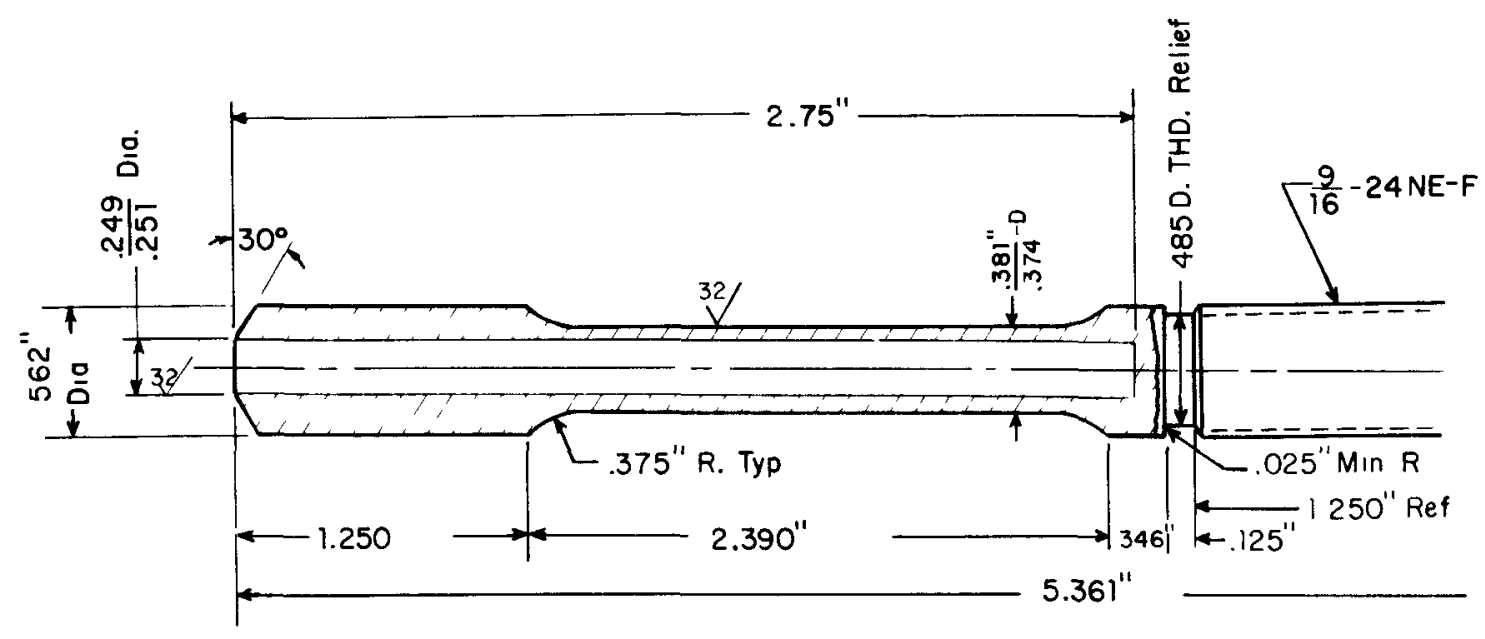


APPENDIX C-6

Single Edge Notched Tensile Specimen
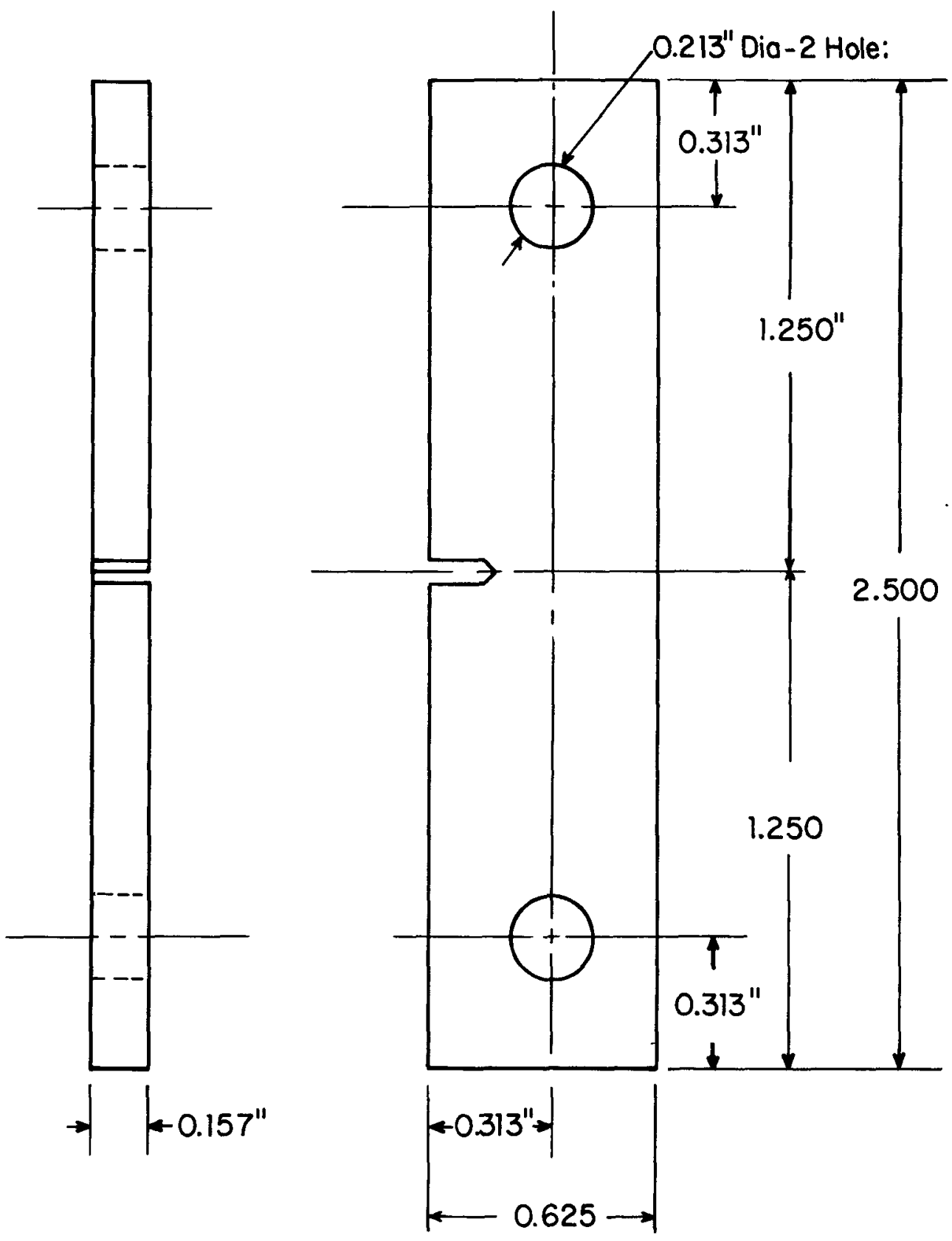
Detail of Notch in Single Edge Notched Tensile Specimen

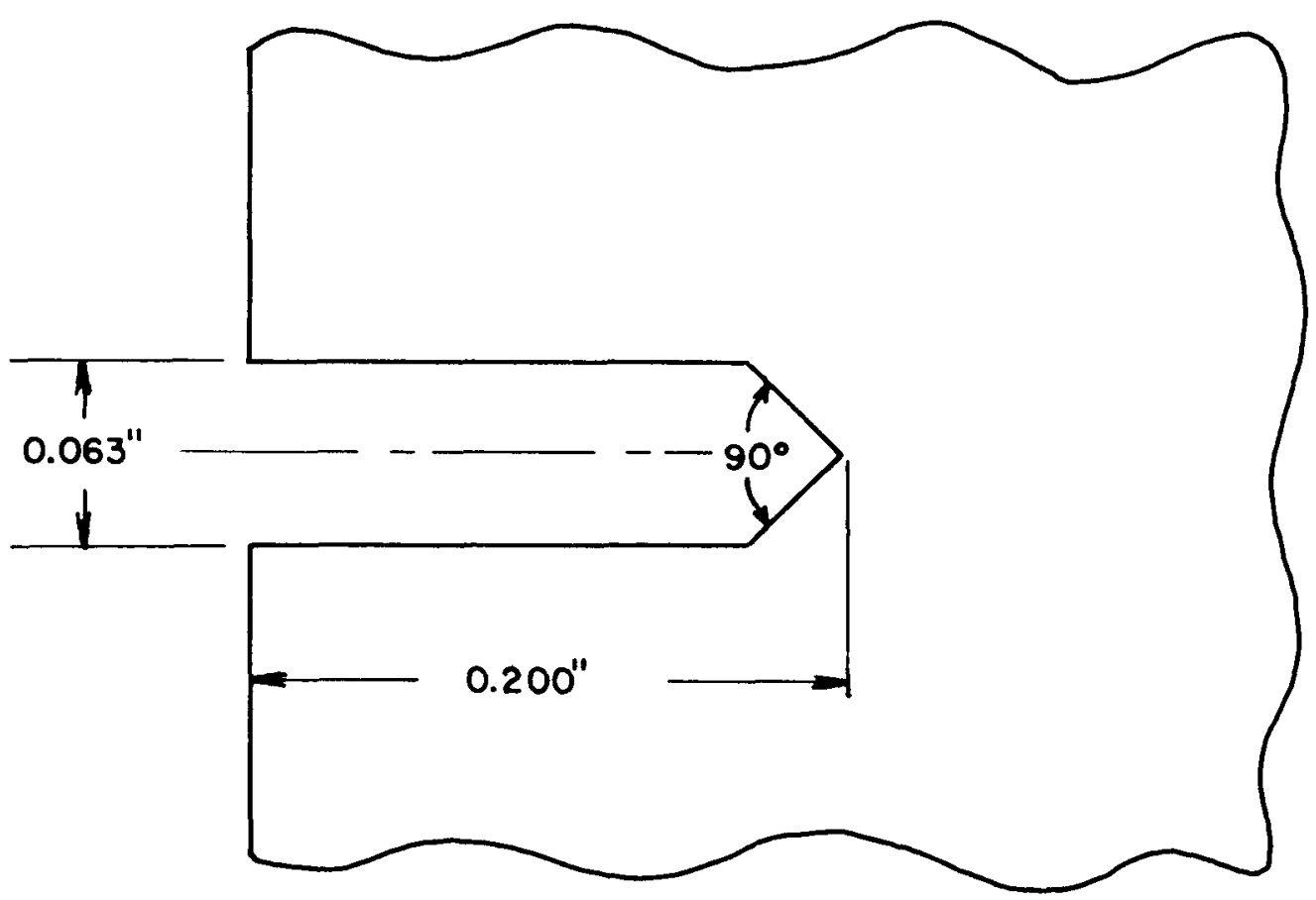

Notes: 1) All demensions $\pm 0.001^{\prime \prime}$

2) Notch root radius $=0.005^{\prime \prime}$

3) To prevent excessive hardening in notch areo, machine finat $0.040^{\prime \prime}$ of notch in five cuts $10.010^{\prime \prime}$ on first cut, $0.010^{\prime \prime}$ on 2nd cut, $0.010^{\prime \prime}$ on 3rd cut, $0.005^{\prime \prime}$ on 4 ith cut and $0.005^{\prime \prime}$ on 5 th cut). 
APPENDIX C-7

C-Shaped Fracture Mechanics Specimen
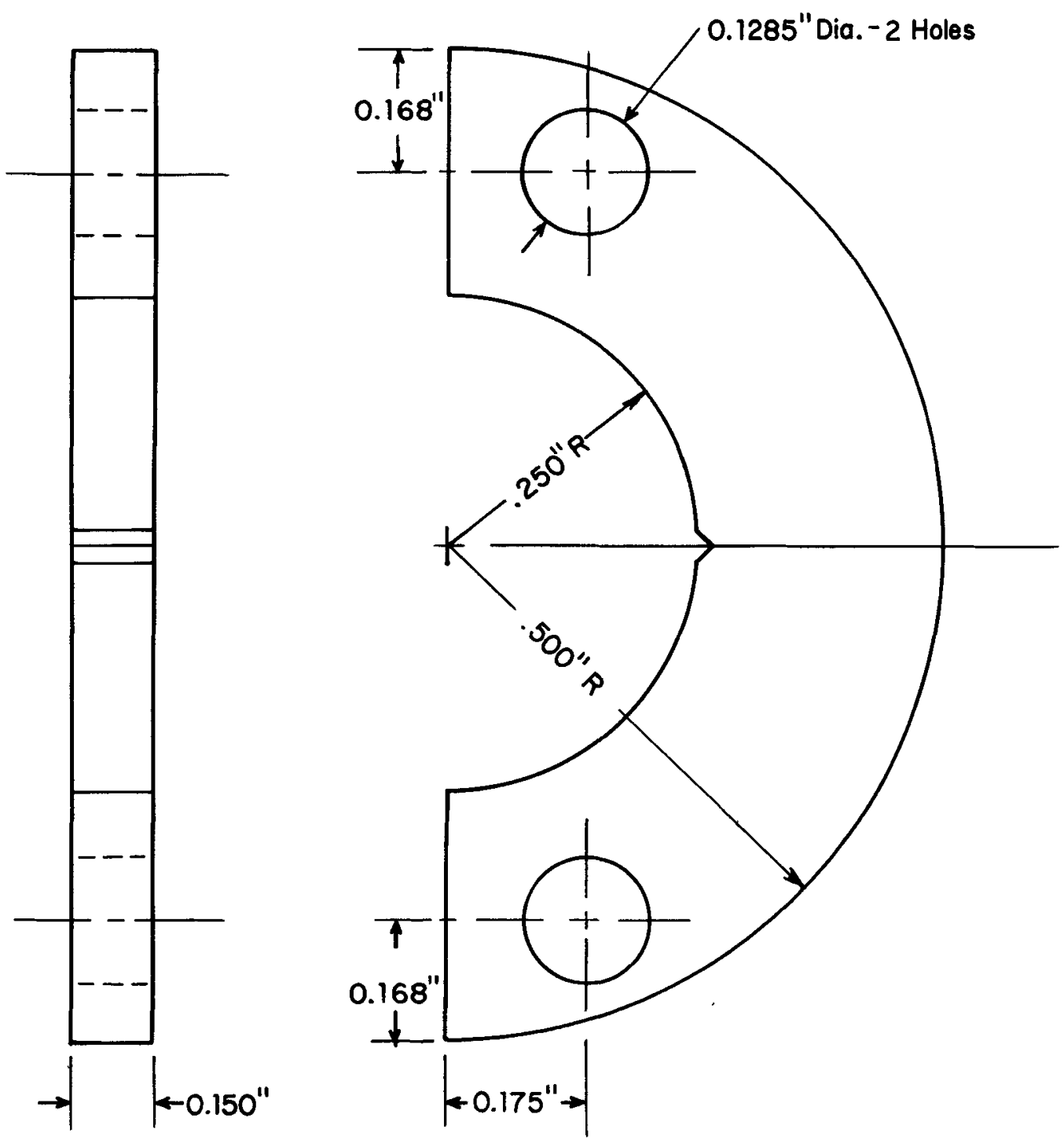
APPENDIX C-7a

Detail of Notch in C-Shaped Fracture Hechanics Specimen

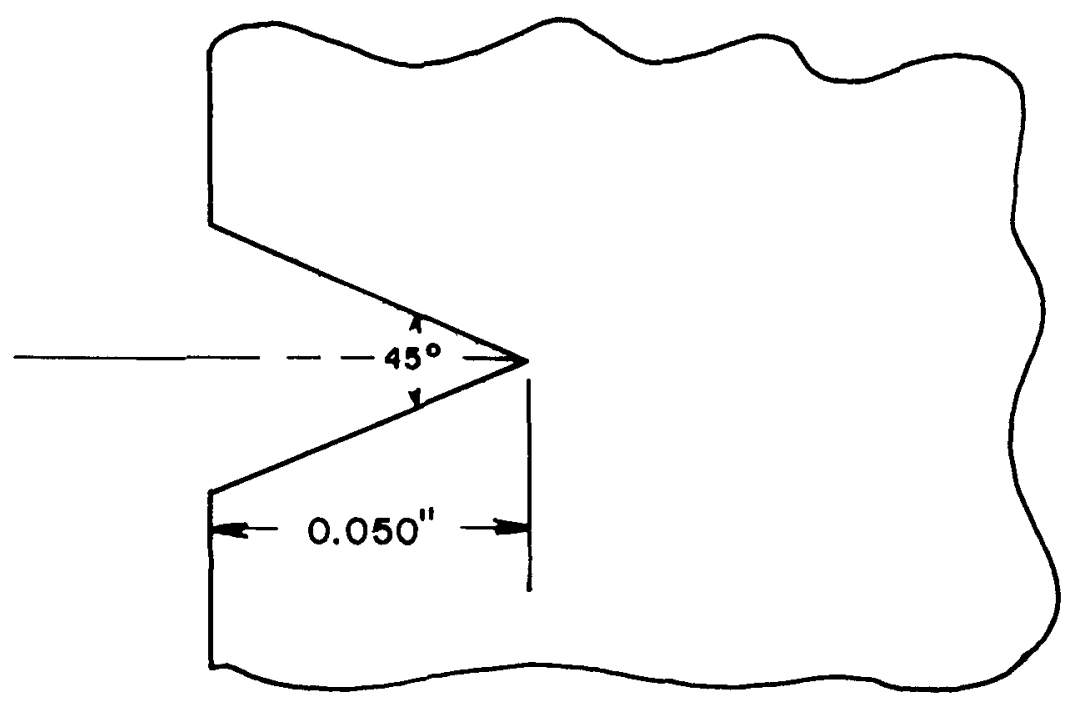

Notes: 1) All demensions $\pm 0.001^{\prime \prime}$

2) Notch root rodius $=0.005^{\prime \prime}$ 
APPENDIX C-8

Impact Specimen: Modified Naval Research Laboratory

Dynamic Tear Specimen
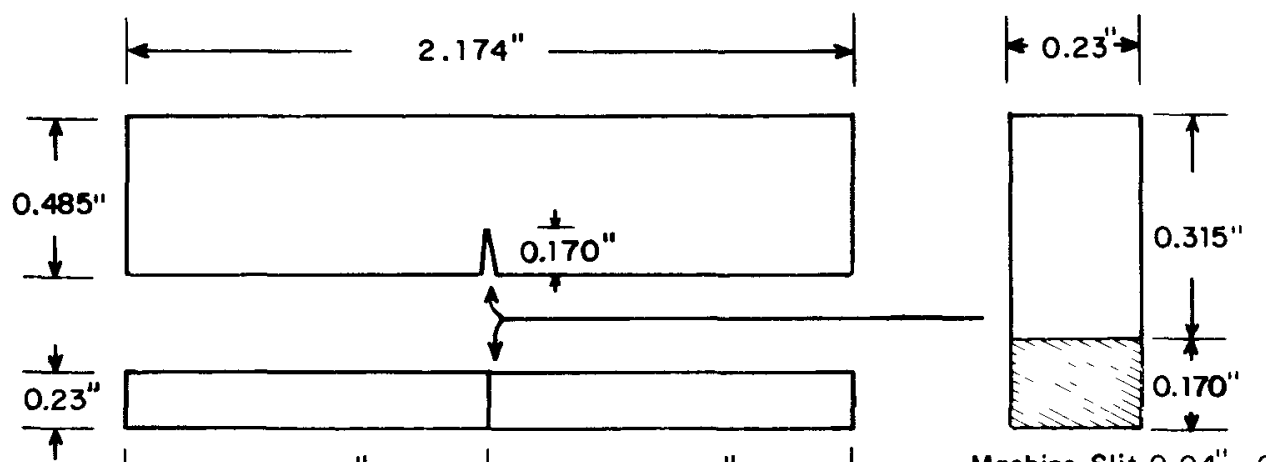

Machine Slit $0.04^{\prime \prime} \times 0.170^{\prime \prime}$ 


\begin{tabular}{|c|c|}
\hline \multicolumn{2}{|c|}{ DATA SHEET D-1 } \\
\hline Element & Weight Percent \\
\hline $\mathrm{C}$ & 0.03 \\
\hline $\mathrm{Mn}$ & 1.57 \\
\hline $\mathbf{P}$ & 0.015 \\
\hline $\mathrm{S}$ & 0.008 \\
\hline $\mathrm{Si}$ & 0.43 \\
\hline $\mathrm{Cr}$ & 18.35 \\
\hline $\mathrm{Ni}$ & 10.29 \\
\hline Mo & 0.17 \\
\hline $\mathbf{N}$ & - \\
\hline A 1 & - \\
\hline $\mathrm{Ti}$ & - \\
\hline $\mathrm{Nb}$ & - \\
\hline $\mathrm{Cu}$ & - \\
\hline
\end{tabular}




$\begin{array}{lc}\text { DATA SHEET D-2 } \\ \text { Heat Analysis Type } 330 \text { Stainless Steel } \\ \text { Element } & \text { Weight Percent } \\ \text { C } & 0.049 \\ \text { Mn } & 1.40 \\ \text { P } & - \\ \text { S } & 0.005 \\ \text { Si } & 1.46 \\ \text { Cr } & 18.40 \\ \text { Ni } & 35.00 \\ \text { Mo } & 0.18 \\ \text { N } & - \\ \text { A1 } & - \\ \text { Ti } & 0.45 \\ \text { Nb } & - \\ \text { Cu } & 0.20\end{array}$

DATA SHEET D-3

Heat Analysis Incoloy $800 \mathrm{H}$

Element Weight Percent

C $\quad 0.08$

Mn $\quad 0.84$

$\mathrm{P}$ -

$\mathrm{S} \quad 0.002$

$\mathrm{Si} \quad 0.51$

$\mathrm{Cr} \quad 19.19$

$\mathrm{Ni} \quad 34.04$

Mo -

N

A1 $\quad 0.36$

Ti 0.41

$\mathrm{Nb}$

$\mathrm{Cu} \quad 0.52$ 


\begin{tabular}{ll} 
DATA SHEET D-4 \\
Heat Analysis & Tenelon \\
Element & Weight Percent \\
\hline $\mathrm{C}$ & - \\
$\mathrm{Mn}$ & 15.3 \\
$\mathrm{P}$ & - \\
$\mathrm{S}$ & - \\
$\mathrm{Si}$ & 0.53 \\
$\mathrm{Cr}$ & 17.4 \\
$\mathrm{Ni}$ & 0.22 \\
$\mathrm{Mo}$ & - \\
$\mathrm{N}$ & $0.4-0.6$ \\
$\mathrm{~A} 1$ & - \\
Ti & - \\
Nb & - \\
$\mathrm{Cu}$ & -
\end{tabular}

DATA SHEET D-5

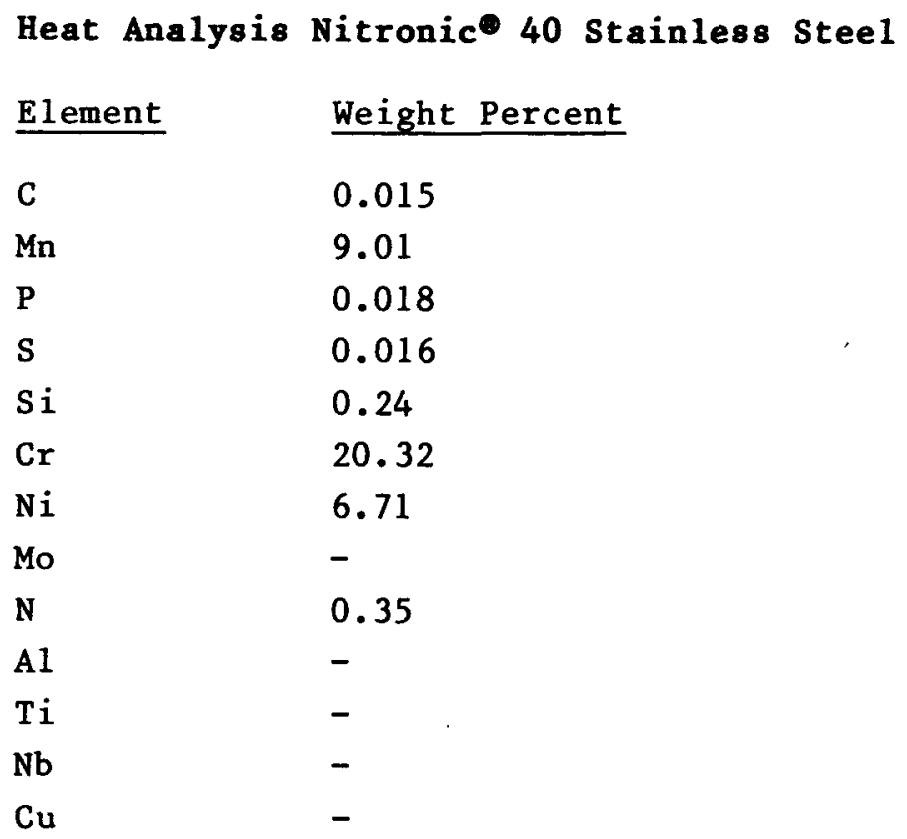




DATA SHEET D-6
\begin{tabular}{ll} 
Heat Analysis & Nitronic 50 Stainless Steel \\
Element & Weight Percent \\
\hline C & 0.05 \\
Mn & 5.44 \\
P & 0.015 \\
S & 0.010 \\
Si & 0.42 \\
Cr & 21.48 \\
Ni & 12.36 \\
Mo & 2.12 \\
N & 0.25 \\
A1 & - \\
Ti & - \\
Nb & 0.19 \\
Cu & - \\
V & 0.2
\end{tabular}

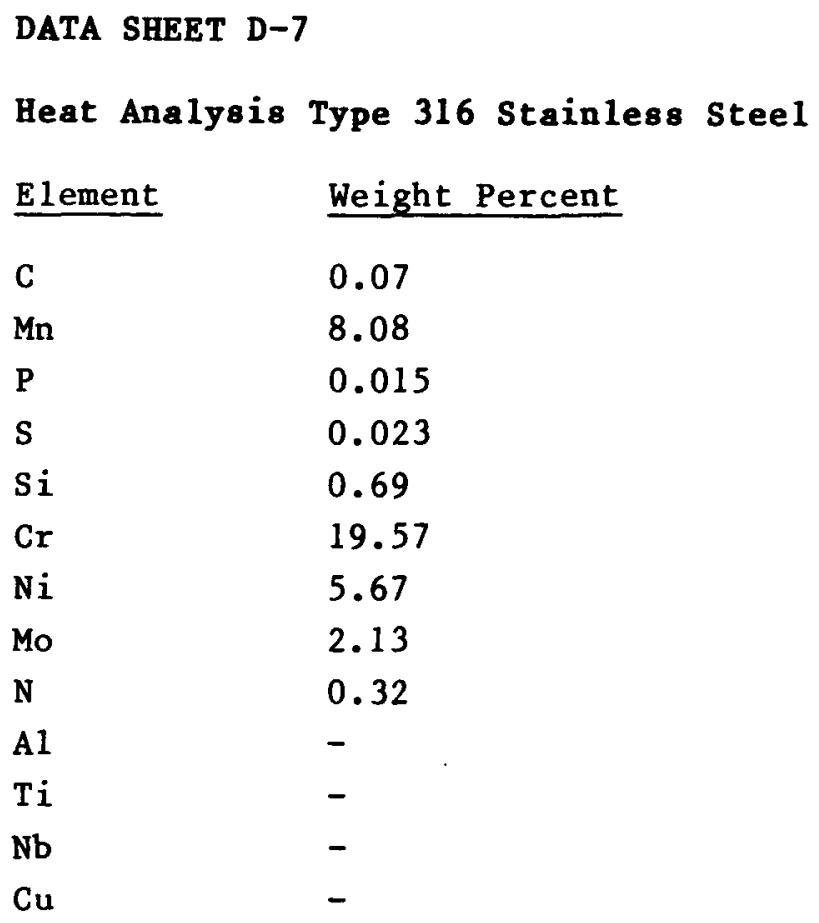




\begin{tabular}{ll} 
DATA SHEET D-8 \\
Heat Analysis & X18-3 Mn Stainless Steel \\
Element & Weight Percent \\
\cline { 2 - 2 } & \\
$\mathrm{C}$ & 0.067 \\
$\mathrm{Mn}$ & 12.4 \\
$\mathrm{P}$ & 0.013 \\
$\mathrm{~S}$ & 0.013 \\
$\mathrm{Si}$ & 0.43 \\
$\mathrm{Cr}$ & 18.55 \\
$\mathrm{Ni}$ & 3.17 \\
$\mathrm{Mo}$ & - \\
$\mathrm{N}$ & 0.33 \\
$\mathrm{~A} 1$ & - \\
$\mathrm{Ti}$ & - \\
$\mathrm{Nb}$ & - \\
$\mathrm{Cu}$ & - \\
$\mathrm{B}$ & 0.0015 \\
\end{tabular}

DATA SHEET D-9

Heat Analysis 18-18 $\mathrm{Plus}^{\circ}$

E1ement Weight Percent

C $\quad 0.11$

Mn $\quad 17.80$

$P \quad 0.020$

$\mathrm{S} \quad 0.004$

$\mathrm{Si} \quad 0.56$

Cr $\quad 17.78$

$\mathrm{Ni} \quad 0.46$

Mo $\quad 1.09$

$\mathrm{N} \quad 0.45$

A1 -

Ti -

$\mathrm{Nb}$

$\mathrm{Cu} \quad 0.95$

Co $\quad 0.01$ 


\begin{tabular}{ll} 
DATA SHEET D-10 \\
Heat Analysis & $304 \mathrm{~N}$ \\
Element & Weight Percent \\
\cline { 2 - 2 } $\mathrm{C}$ & 0.06 \\
$\mathrm{Mn}$ & 1.66 \\
$\mathrm{P}$ & 0.30 \\
$\mathrm{~S}$ & 0.025 \\
$\mathrm{Si}$ & 0.19 \\
$\mathrm{Cr}$ & 18.37 \\
$\mathrm{Ni}$ & 8.43 \\
$\mathrm{Mo}$ & 0.10 \\
$\mathrm{~N}$ & 0.250 \\
$\mathrm{Al}$ & - \\
$\mathrm{Ti}$ & - \\
$\mathrm{Nb}$ & - \\
$\mathrm{Cu}$ & 0.15
\end{tabular}

DATA SHEET D-11

Heat Analysis Carpenter $20 \mathrm{Cb}-3^{\circ}$

Element Weight Percent

C

0.018

Mn 1.60

$P \quad 0.028$

S $\quad 0.007$

Si $\quad 0.44$

Cr $\quad 20.60$

$\mathrm{Ni} \quad 34.90$

Mo $\quad 4.33$

N $\quad-$

Al -

Ti -

$\mathrm{Nb} \quad 0.39$

$\mathrm{Cu} \quad 0.20$ 